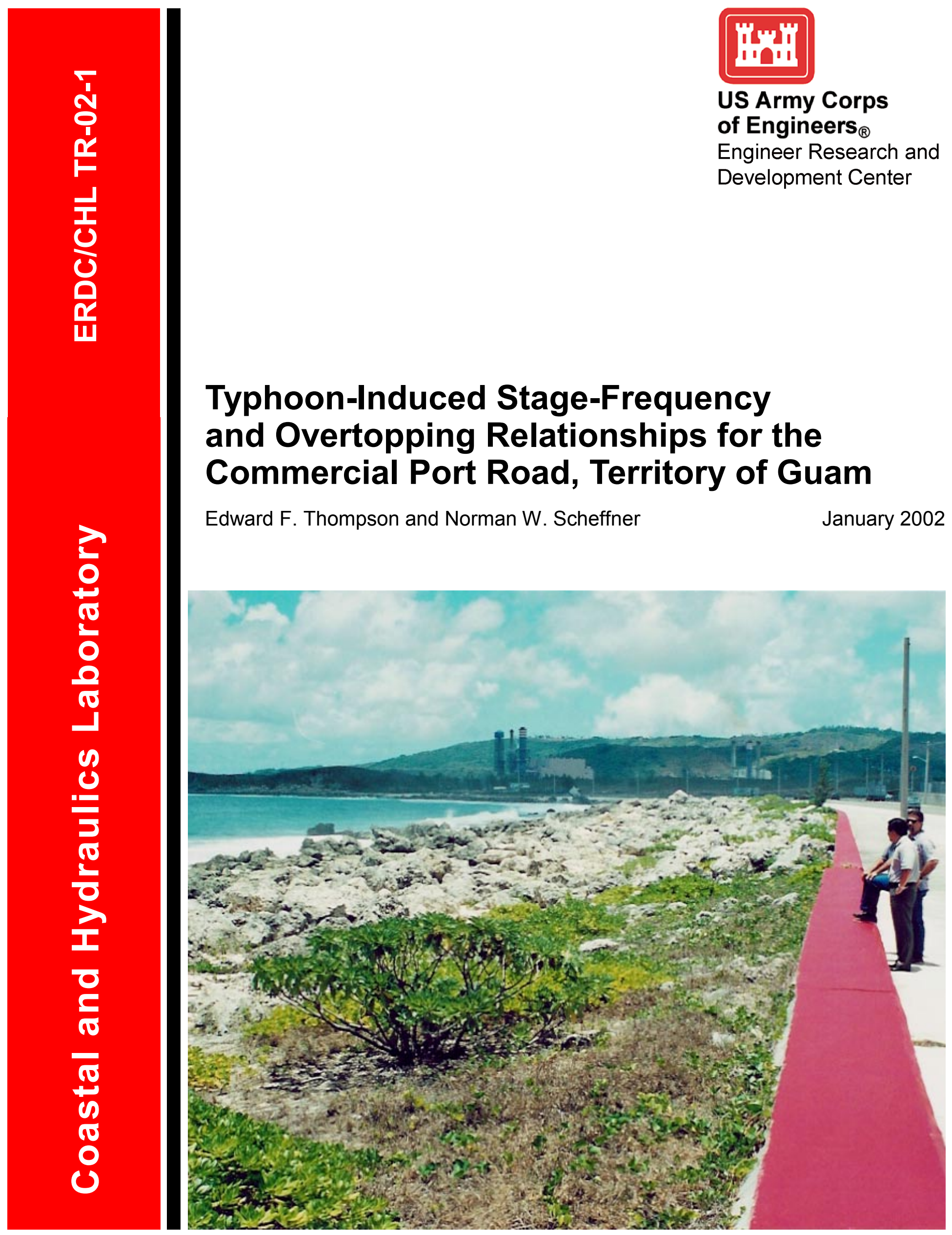


The contents of this report are not to be used for advertising, publication, or promotional purposes. Citation of trade names does not constitute an official endorsement or approval of the use of such commercial products.

The findings of this report are not to be construed as an official Department of the Army position, unless so designated by other authorized documents. 
ERDC/CHL TR-02-1

January 2002

\title{
Typhoon-Induced Stage-Frequency and Overtopping Relationships for the Commercial Port Road, Territory of Guam
}

\author{
by Edward F. Thompson, Norman W. Scheffner \\ Coastal and Hydraulics Laboratory \\ U.S. Army Engineer Research and Development Center \\ 3909 Halls Ferry Road \\ Vicksburg, MS 39180-6199
}

Final report

Approved for public release; distribution is unlimited 


\section{Contents}

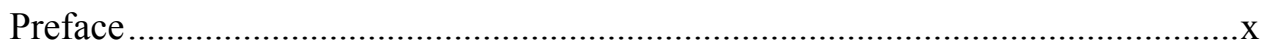

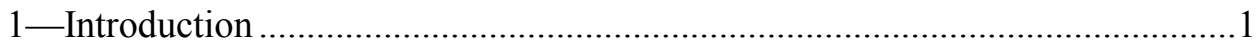

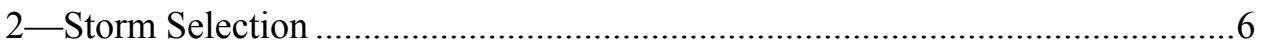

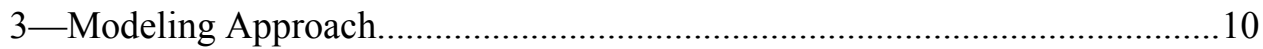

Wind and Atmospheric Pressure Field Model..............................................11

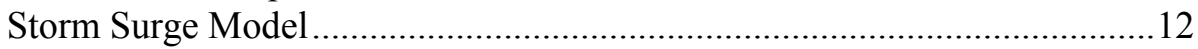

Wave and Wave Transformation Models ....................................................17

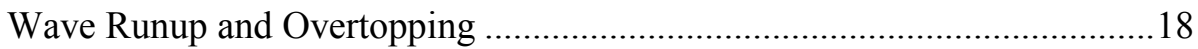

Reduction factor for influence of a berm .............................................22

Reduction factor for influence of shallow foreshore .............................24

Reduction factor for influence of roughness........................................24

Reduction factor for influence of angle of wave attack .........................24

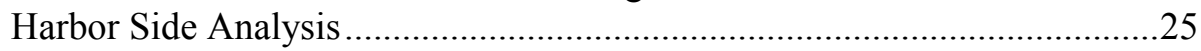

Wave propagation through harbor entrance ........................................25

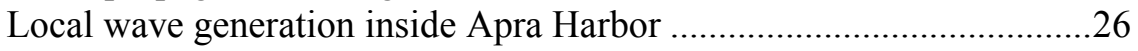

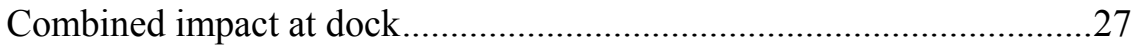

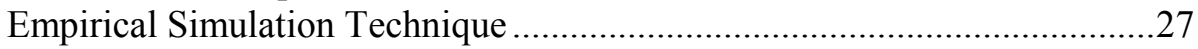

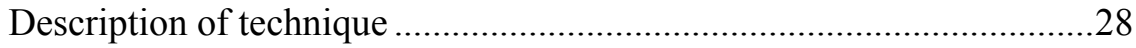

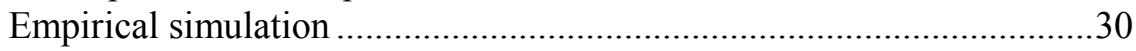

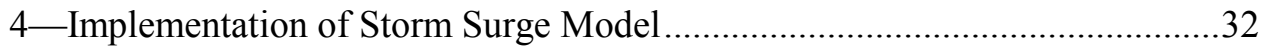

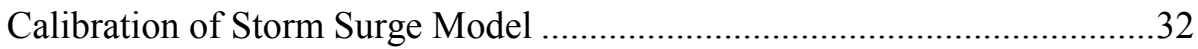

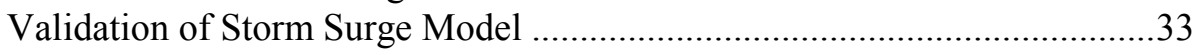

5-Development of Overtopping and Stage-Frequency Relationships ................36

Storm Surge/Tidal Elevation Relationship ...................................................36

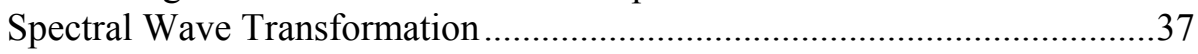

Water Level Over Reef...............................................................................38

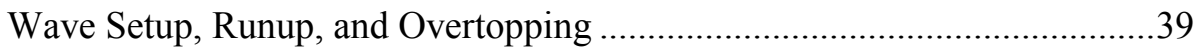

Implementation of Overtopping Method ..................................................40

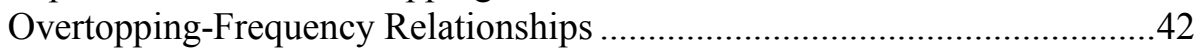

Harbor Side Stage-Frequency Relationships ..............................................42

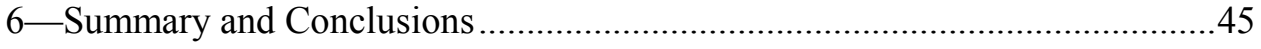

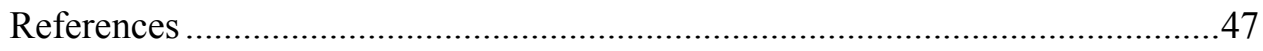

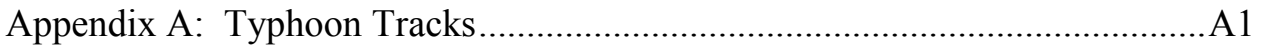




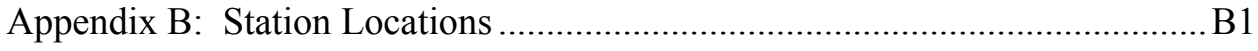

Appendix C: Overtopping-Frequency Relationship Tables .............................. 1

Appendix D: Tables of Maximum Overtopping Rates and Other

Information by Storm D1

Appendix E: Stage-Frequency Relationship Tables for Harbor Side . E1

Appendix F: Tables of Wave Parameters and Water Levels by Storm at

Harbor Side Storm Surge Stations F1

SF 298

\section{List of Figures}

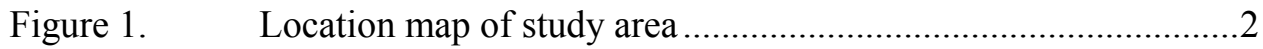

Figure 2. $\quad$ Location map, Apra Harbor, Guam.............................................3

Figure 3. Apra Harbor container yard, looking west along Cabras

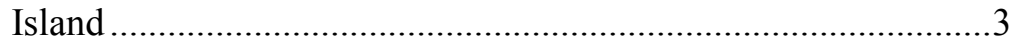

Figure 4. Example of existing and plan profiles, Sta $16+00$.......................4

Figure 5. Complete computational grid for Guam study..........................15

Figure 6. Computational grid showing detail for Guam...........................16

Figure 7. Computational grid showing detail for Apra Harbor ..................16

Figure 8. Definition sketch, equivalent slope for berm profile .................23

Figure 9. Definition sketch, representative slope for berm profile ..........23

Figure 10. Tide gauge data, Apra Harbor, January 1997 ............................33

Figure 11. Probability distribution of tide gauge data, Apra Harbor,

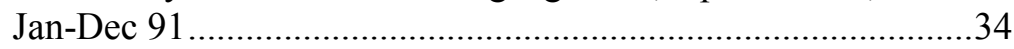

Figure 12. Measured and modeled water level at the Apra Harbor

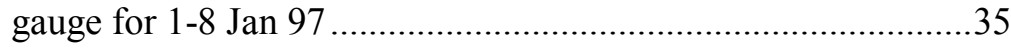

Figure 13. Measured and modeled water level in Apra Harbor for Typhoon Omar, during 0600 UTC 26 Aug through 1300 29 Aug 92 35

Figure 14. Storm surge station locations for Cabras Island.........................37

Figure 15. Station overtopping rates, 100-year return period ....................43

Figure 16. Total overtopping rate along project length..............................44

Figure A1. Storm track for Agnes (2348) ................................................A2

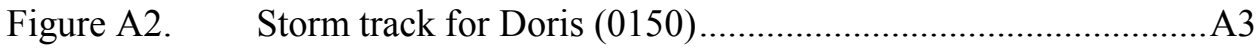

Figure A3. Storm track for Nina (0853) .................................................. 4 
Figure A4. Storm track for Alice (1953) ...............................................A5

Figure A5. Storm track for Hester (1557) ............................................. 6

Figure A6. Storm track for Lola (2057) …............................................A7

Figure A7. Storm track for Nancy (1861) ..............................................A 8

Figure A8. Storm track for Karen (2762) ...............................................A9

Figure A9. Storm track for Olive (0163).............................................A10

Figure A10. Storm track for Susan (2563) ..............................................A11

Figure A11. Storm track for Bess (2965) .................................................A12

Figure A12. Storm track for Gilda (3367)...............................................13

Figure A13. Storm track for Irma (2168) .................................................

Figure A14. Storm track for Amy (0571) ...............................................A15

Figure A15. Storm track for Pamela (0676) .............................................A16

Figure A16. Storm track for Kim (1977)..................................................17

Figure A17. Storm track for Tip (2379) .................................................A18

Figure A18. Storm track for Lynn (2187) ...............................................A19

Figure A19. Storm track for Roy (0188) …….....................................A20

Figure A20. Storm track for Andy (0289) ..............................................A21

Figure A21. Storm track for Koryn (0190) ............................................A22

Figure A22. Storm track for Russ (3190) ...............................................A23

Figure A23. Storm track for Seth (2691)..............................................A24

Figure A24. Storm track for Omar (1592).............................................A25

Figure A25. Storm track for Gay (3192) ..............................................A26

Figure A26. Storm track for Wilda (3594) ............................................A27

Figure A27. Storm track for Paka (0597) ..............................................A28

Figure A28. Storm track for Keith (2997)..............................................A29

Figure A29. Storm track for hypothetical storm 5163 .............................A30

Figure A30. Storm track for hypothetical storm 6163 ............................A31

\section{List of Tables}

Table 1. Typhoons Selected for Modeling, Apra Harbor, Guam ...............9

Table 2. Statistics of Typhoon Travel Direction....................................... 9 
Table 3. Storm Surge Grid Parameters.................................................15

Table 4. WISWAVE Grid Parameters ..................................................... 18

Table 5. Deepwater Wave Stations .......................................................... 19

Table 6. Tidal Constituents in Apra Harbor................................................34

Table 7. Ponding Level Coefficients for Irregular Waves (Seelig

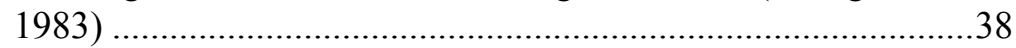

Table 8. Maximum Calculated Overtopping Rates for Calibration

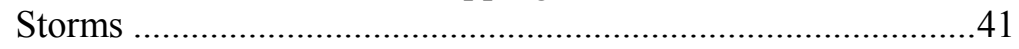

Table 9. Maximum Overtopping Rates along Project Length..................43

Table B1. Station Locations for Storm Surge Modeling .......................... B1

Table C1. Return Period, Maximum Overtopping Rate, and Overtopping Rate Standard Deviation for Sta $0+00$, Existing Profile

Table C2. Return Period, Maximum Overtopping Rate, and Overtopping Rate Standard Deviation for Sta 2+00, Existing Profile

Table C3. Return Period, Maximum Overtopping Rate, and Overtopping Rate Standard Deviation for Sta 4+00, Existing Profile

Table C4. Return Period, Maximum Overtopping Rate, and Overtopping Rate Standard Deviation for Sta 6+00, Existing Profile

Table C5. Return Period, Maximum Overtopping Rate, and Overtopping Rate Standard Deviation for Sta 8+00, Existing Profile

Table C6. Return Period, Maximum Overtopping Rate, and Overtopping Rate Standard Deviation for Sta 10+00, Existing Profile

Table C7. Return Period, Maximum Overtopping Rate, and Overtopping Rate Standard Deviation for Sta $12+00$, Existing Profile

Table C8. Return Period, Maximum Overtopping Rate, and Overtopping Rate Standard Deviation for Sta 14+00, Existing Profile

Table C9. Return Period, Maximum Overtopping Rate, and Overtopping Rate Standard Deviation for Sta 16+00, Existing Profile

Table C10. Return Period, Maximum Overtopping Rate, and Overtopping Rate Standard Deviation for Sta $18+00$, Existing Profile 
Table C11. Return Period, Maximum Overtopping Rate, and Overtopping Rate Standard Deviation for Sta 20+00, Existing Profile

Table C12. Return Period, Maximum Overtopping Rate, and Overtopping Rate Standard Deviation for Sta 22+00, Existing Profile

Table C13. Return Period, Maximum Overtopping Rate, and Overtopping Rate Standard Deviation for Sta $24+00$, Existing Profile

Table C14. Return Period, Maximum Overtopping Rate, and Overtopping Rate Standard Deviation for Sta 26+00, Existing Profile

Table C15. Return Period, Maximum Overtopping Rate, and

Overtopping Rate Standard Deviation for Sta 28+00,

Existing Profile

Table C16. Return Period, Maximum Overtopping Rate, and Overtopping Rate Standard Deviation for Sta 0+00, Plan

Profile....

Table C17. Return Period, Maximum Overtopping Rate, and Overtopping Rate Standard Deviation for Sta 2+00, Plan Profile.....

Table C18. Return Period, Maximum Overtopping Rate, and Overtopping Rate Standard Deviation for Sta 4+00, Plan Profile.

Table C19. Return Period, Maximum Overtopping Rate, and Overtopping Rate Standard Deviation for Sta 6+00, Plan Profile. C6

Table C20. Return Period, Maximum Overtopping Rate, and Overtopping Rate Standard Deviation for Sta 8+00, Plan Profile.

Table C21. Return Period, Maximum Overtopping Rate, and Overtopping Rate Standard Deviation for Sta 10+00, Plan Profile

Table C22. Return Period, Maximum Overtopping Rate, and Overtopping Rate Standard Deviation for Sta $12+00$, Plan Profile.

Table C23. Return Period, Maximum Overtopping Rate, and Overtopping Rate Standard Deviation for Sta $14+00$, Plan Profile.

Table C24. Return Period, Maximum Overtopping Rate, and Overtopping Rate Standard Deviation for Sta $16+00$, Plan Profile. . 77 
Table C25. Return Period, Maximum Overtopping Rate, and Overtopping Rate Standard Deviation for Sta $18+00$,

Plan Profile

Table C26. Return Period, Maximum Overtopping Rate, and

Overtopping Rate Standard Deviation for Sta 20+00,

Plan Profile

Table C27. Return Period, Maximum Overtopping Rate, and

Overtopping Rate Standard Deviation for Sta 22+00,

Plan Profile

Table C28. Return Period, Maximum Overtopping Rate, and

Overtopping Rate Standard Deviation for Sta 24+00,

Plan Profile

Table C29. Return Period, Maximum Overtopping Rate, and

Overtopping Rate Standard Deviation for Sta 26+00,

Plan Profile

Table C30. Return Period, Maximum Overtopping Rate, and

Overtopping Rate Standard Deviation for Sta 28+00,

Plan Profile.

Table D1. Wave Parameters, Water Level Components, and

Maximum Overtopping Rates by Storm, Sta $0+00$

Table D2. Wave Parameters, Water Level Components, and

Maximum Overtopping Rates by Storm, Sta $2+00$

Table D3. Wave Parameters, Water Level Components, and

Maximum Overtopping Rates by Storm, Sta $4+00$

Table D4. Wave Parameters, Water Level Components, and

Maximum Overtopping Rates by Storm, Sta $6+00$ .D5

Table D5. Wave Parameters, Water Level Components, and Maximum Overtopping Rates by Storm, Sta $8+00$

Table D6. Wave Parameters, Water Level Components, and Maximum Overtopping Rates by Storm, Sta $10+00$

Table D7. Wave Parameters, Water Level Components, and Maximum Overtopping Rates by Storm, Sta $12+00$

Table D8. Wave Parameters, Water Level Components, and Maximum Overtopping Rates by Storm, Sta $14+00$

Table D9. Wave Parameters, Water Level Components, and Maximum Overtopping Rates by Storm, Sta 16+00 D10

Table D10. Wave Parameters, Water Level Components, and Maximum Overtopping Rates by Storm, Sta $18+00$.... D1 1

Table D11. Wave Parameters, Water Level Components, and Maximum Overtopping Rates by Storm, Sta $20+00$ D12

Table D12. Wave Parameters, Water Level Components, and Maximum Overtopping Rates by Storm, Sta $22+00 \ldots$ D13 
Table D13. Wave Parameters, Water Level Components, and Maximum Overtopping Rates by Storm, Sta $24+00$ D14

Table D14. Wave Parameters, Water Level Components, and Maximum Overtopping Rates by Storm, Sta $26+00$ D15

Table D15. Wave Parameters, Water Level Components, and Maximum Overtopping Rates by Storm, Sta $28+00$ D16

Table E1. Return Period, Maximum Water Level, and Water Level Standard Deviation for Storm Surge Sta 6 E2

Table E2. Return Period, Maximum Water Level, and Water Level Standard Deviation for Storm Surge Sta 7. E2

Table E3. Return Period, Maximum Water Level, and Water Level Standard Deviation for Storm Surge Sta 8 E2

Table E4. Return Period, Maximum Water Level, and Water Level Standard Deviation for Storm Surge Sta 9 E2

Table E5. Return Period, Maximum Water Level, and Water Level Standard Deviation for Storm Surge Sta 10

Table E6. Return Period, Maximum Water Level, and Water Level Standard Deviation for Storm Surge Sta 11

Table E7. Return Period, Maximum Water Level, and Water Level Standard Deviation for Storm Surge Sta 12 E3

Table F1. Wave Parameters and Water Levels by Storm, Storm Surge Sta 6 F2

Table F2. Wave Parameters and Water Levels by Storm, Storm Surge Sta 7 F3

Table F3. Wave Parameters and Water Levels by Storm, Storm Surge Sta 8 F4

Table F4. Wave Parameters and Water Levels by Storm, Storm Surge Sta 9 F5

Table F5. Wave Parameters and Water Levels by Storm, Storm Surge Sta 10 F6

Table F6. Wave Parameters and Water Levels by Storm, Storm Surge Sta 11

Table F7. Wave Parameters and Water Levels by Storm, Storm Surge Sta 12 F8 


\section{Preface}

This report describes the procedures and results of a typhoon stagefrequency and overtopping analysis for a vulnerable section of the commercial port road along Cabras Island, Apra Harbor, U.S. Territory of Guam. The study was performed by the U.S. Army Engineer Research and Development Center (ERDC), Coastal and Hydraulics Laboratory (CHL), for the U.S. Army Engineer District, Honolulu. Mr. Lincoln C. Gayagas, formerly of the Honolulu District, and Mr. Stanley Boc, Honolulu District, were the study managers and points of contact.

The investigation reported herein was conducted by Drs. Edward F. Thompson and Norman W. Scheffner, both formerly of the Coastal Hydrodynamics Branch, and presently of the Coastal Harbors and Structures Branch and Estuarine Engineering Branch, CHL. The final report was prepared by Dr. Thompson. Dr. Adele Militello, formerly of CHL, contributed significantly to the study as a result of her work on a previous study of hurricane impacts on the Territory of American Samoa. Mr. David J. Mark, formerly of the Coastal Hydrodynamics Branch, and presently of the Estuarine Engineering Branch, CHL, helped guide critical phases of the tide and storm surge modeling and overall study. Dr. Donald L. Ward, formerly of the Harbors and Entrances Branch, and presently of the Coastal Harbors and Structures Branch, CHL, provided valuable consultation on the runup and overtopping part of the study.

This study was performed under the general supervision of Dr. James R. Houston, former Director, CHL, and Mr. Thomas W. Richardson, Acting Director, CHL. Direct supervision of this project was provided by Dr. Zeki Demirbilek, former Acting Chief, Coastal Hydrodynamics Branch, and Mr. Dennis G. Markle, Chief, Coastal Harbors and Structures Branch.

At the time of publication of this report, Dr. James R. Houston was Director of ERDC, and COL John W. Morris III, EN, was Commander and Executive Director. 


\section{Introduction}

The Territory of Guam is principally an island located in the western Pacific Ocean at approximately $144.5^{\circ}$ east longitude and $13.5^{\circ}$ north latitude. Guam lies north of Australia and northwest of New Zealand (Figure 1). Guam is one of the Mariana Islands, an island group at the southern end of a volcanic ridge stretching south from the Japanese island of Honshu. The Mariana Trench, a deep rift in the ocean floor, wraps around Guam to the east and south.

The island of Guam is approximately $50 \mathrm{~km}$ (30 miles) long and 6 to $14 \mathrm{~km}$ ( 4 to 8.5 miles) wide. It covers an area of $540 \mathrm{sq} \mathrm{km} \mathrm{(209} \mathrm{square} \mathrm{miles).} \mathrm{Most}$ coastal shelf and beach areas are narrow, with steep, rugged terrain inland of the coast, as is typical for volcanic islands. Fringing coral reefs are common around the island. Water depth over the reefs is very shallow and some reef areas are exposed at low tide. Thus, the reefs provide a measure of natural protection from damaging waves to coastal areas.

Guam's low-latitude location is favorable for tropical storm and typhoon formation and passage. The island often experiences typhoon impacts and occasionally a typhoon passes directly over the island. Typical typhoon impacts include wind and rainfall damage to buildings, roads, and crops and coastal damage due to high waves and water levels.

Apra Harbor, Guam's commercial port, is located on the west side of the island. The harbor is well protected by a combination of natural features and Glass Breakwater, a long man-made breakwater connecting into Cabras Island on the shoreward end (Figure 2). Cabras Island is a narrow, east-west oriented island which not only affords protection to the harbor, but also accommodates many of the commercial port facilities.

Route 11, the port access road, runs along the north side of Cabras Island. The container yard occupies most of the west-central part of Cabras Island (Figure 3). In this area, the road is protected from the sea by a relatively low, recurved concrete seawall fronted by a rubble-strewn beach. During storms, waves can run up the beach, overtop the seawall, and cause disruption and damage to the road and port facilities beyond the road. Potential damage during intense storms is significant. 


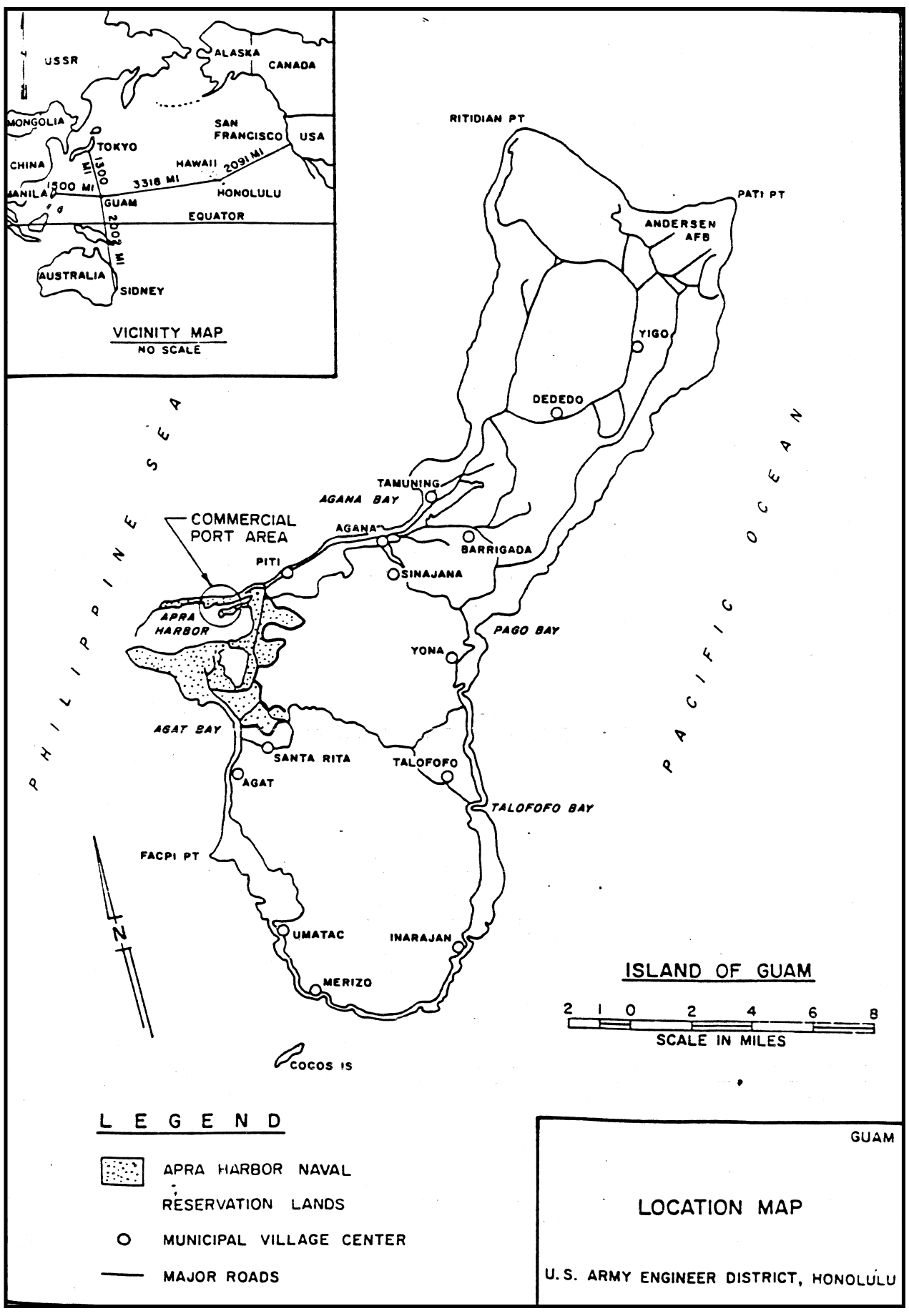

Figure 1. Location map of study area (To convert miles to kilometers, multiply by 1.609347 )

The U.S. Army Engineer District, Honolulu, and U.S. Army Engineer Pacific Ocean Division have developed a project design to greatly reduce the vulnerability of the road and container yard to overtopping and flooding (USAED, Pacific Ocean, 1995). The project involves construction of an armored, lowcrested berm in the ocean beach profile. An example of existing and plan 


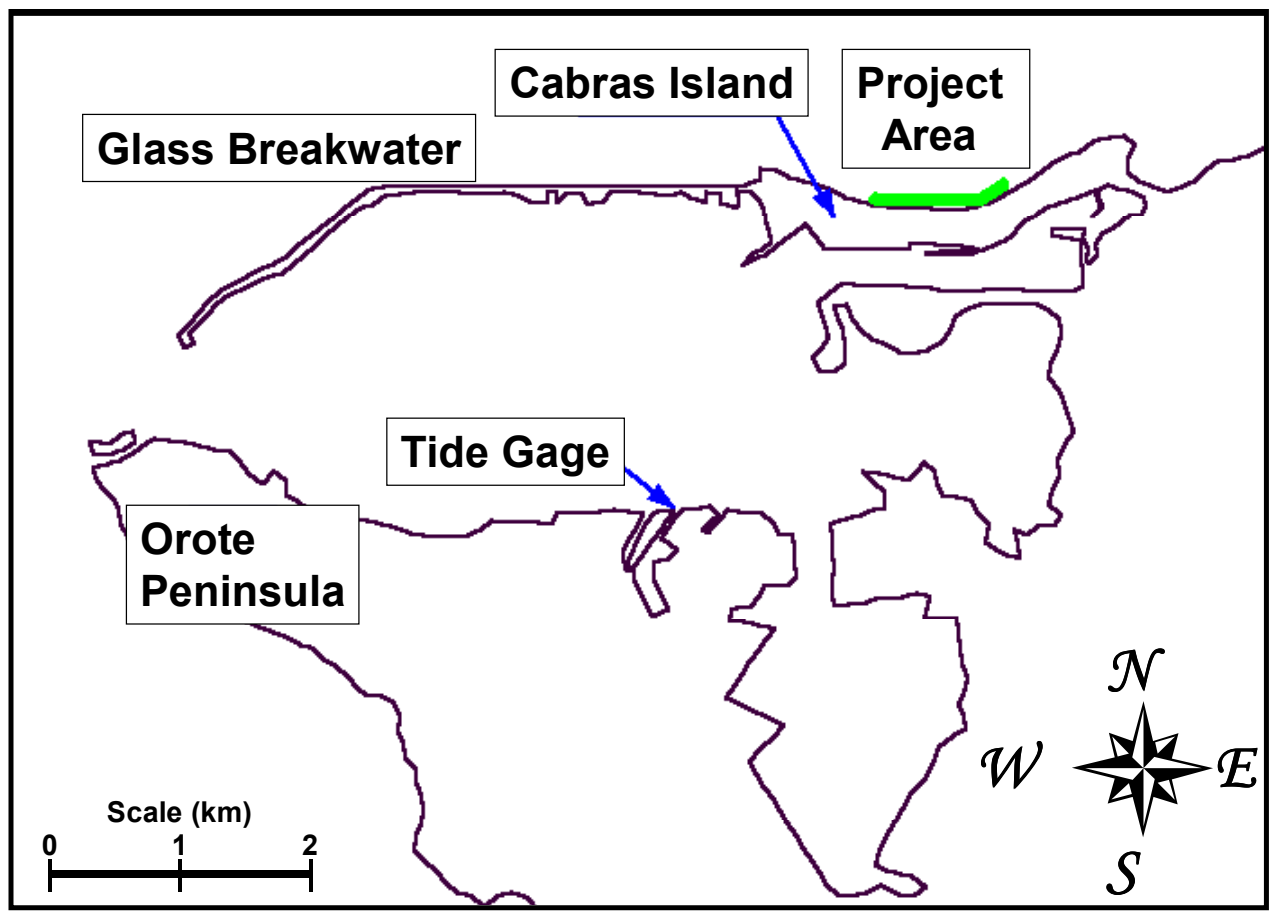

Figure 2. Location map, Apra Harbor, Guam

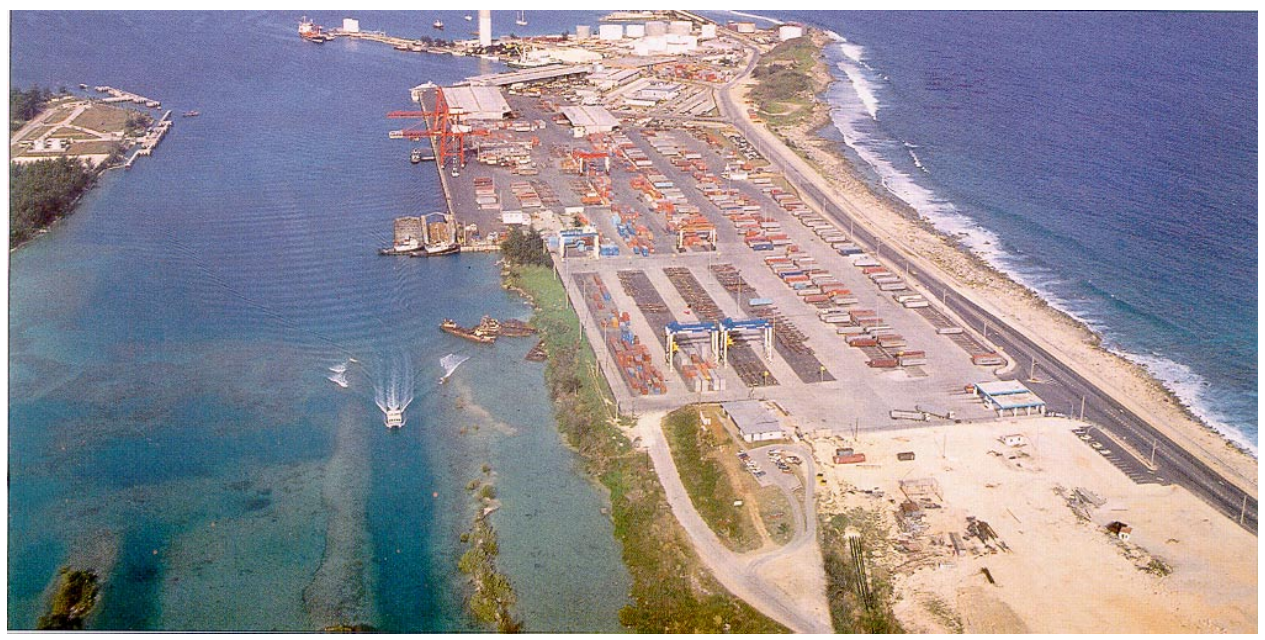

Figure 3. Apra Harbor container yard, looking west along Cabras Island (Port Authority of Guam)

profiles is shown in Figure 4. The existing seawall is unaffected by the project. The present study by the U.S. Army Engineer Research and Development Center (ERDC), Coastal and Hydraulics Laboratory (CHL), was undertaken to assist the Honolulu District in evaluating the design effectiveness by calculating typhoon stage-frequency and overtopping relationships for both existing and plan conditions. 


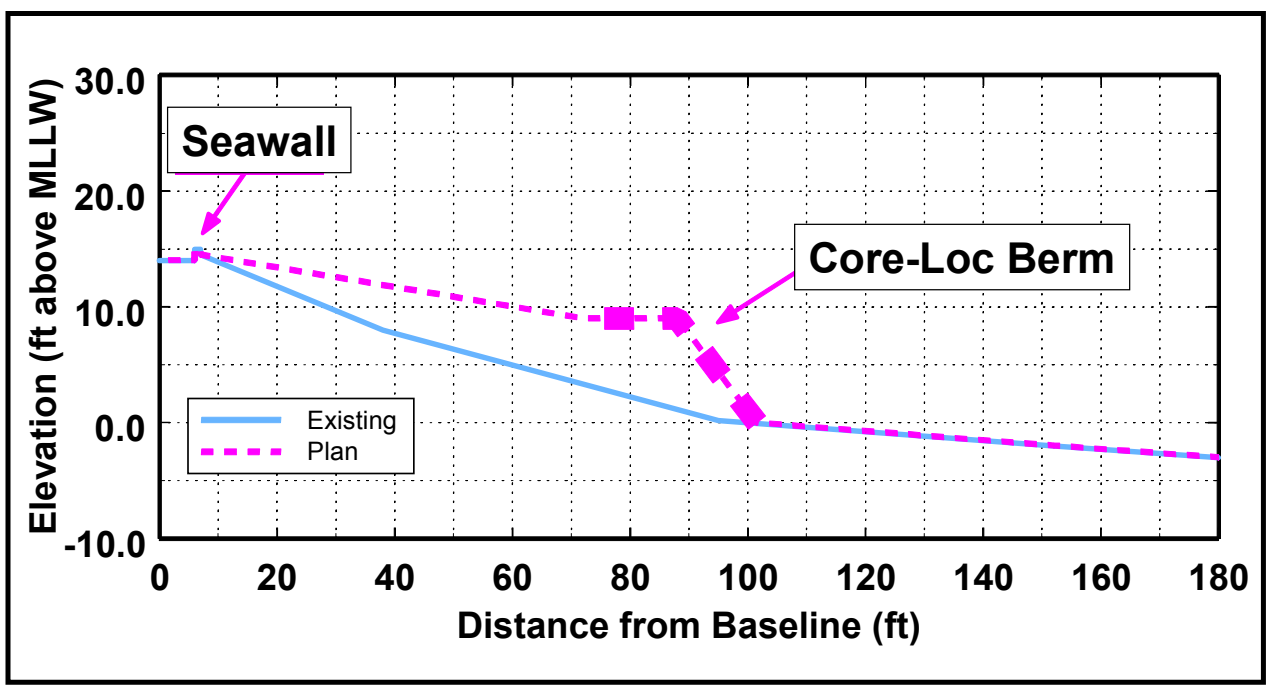

Figure 4. Example of existing and plan profiles, Sta 16+00 (To convert feet to meters, multiply by 0.3048 )

This report describes the procedures and results of the typhoon stagefrequency and overtopping analysis for the proposed project area along Cabras Island, Apra Harbor, Territory of Guam. Many of the techniques employed in this study have been successfully applied in previous stage-frequency analyses (Mark 1996; Mark and Scheffner 1997; Militello and Scheffner 1998). The present study differs from earlier studies in two significant ways: first, the key study result is overtopping rates rather than water levels; and second, plan coastal profiles include a proposed berm configuration designed to reduce runup and overtopping.

The analysis for this study consisted of six tasks. The first task was development of a typhoon database for the western Pacific Ocean and analysis of storm statistics and correlations. Storms impacting the study area were selected from the database to create a smaller, representative group of storms called the training set. A planetary boundary layer model was applied to calculate wind and atmospheric pressure fields for each storm in the training set.

The second task consisted of simulation of storm surge by application of a long-wave, finite-element hydrodynamic model. For each storm in the training set, storm surge was calculated at selected sites in the study area. The third task consisted of wave parameter calculation for each storm by application of a wave growth/propagation model and a nearshore wave-transformation model. The fourth task consisted of time-series calculation of ponding level, setup, runup, and overtopping for each storm. These calculations were performed for profiles specified by the Honolulu District for both existing and plan conditions.

The fifth task was the development of frequency-of-occurrence relationships for rates of overtopping along the seawall. These relationships were developed by application of the Empirical Simulation Technique (EST) to relate typhoon parameters and the corresponding storm overtopping rates. The EST is a statistical resampling procedure that applies historical data to develop joint 
probability relationships among the various measured storm parameters (e.g., maximum wind speed). The resampling scheme generates large populations of data that are statistically similar to a much smaller database of historical events, i.e., the training set of storms. Application of the EST to the expanded storm set produces a database of peak overtopping rates by repeatedly simulating multipleyear periods (e.g., 200-year periods) of storm activity. Expected overtopping rate relationships are then calculated from the database of peak storm-induced overtopping rates. Because of the repeated simulations, a measure of expected variability of calculated overtopping rates is also provided.

The container yard may also be affected by flooding from the harbor side. The sixth task was to evaluate this exposure. Deepwater waves incident to the harbor were propagated through the harbor entrance gap and combined with waves generated by local storm winds in the harbor, giving wave estimates along the commercial dock. Storm surge water levels available from storm surge simulations were then combined with incident and reflected wave conditions along the dock to give water-level estimates. The EST methodology was applied to the set of peak water levels from each storm to produce stage-frequency relationships along the dock.

This report is divided into six chapters. Following the introduction, Chapter 2 describes selection of storms to be modeled. Chapter 3 describes key models and methods used in the study including meteorological, wave, and longwave hydrodynamic models, EST, overtopping analysis, and harbor side analysis. Chapter 4 discusses long-wave hydrodynamic model calibration, validation, and implementation. Chapter 5 reviews the methods as applied in this study for calculation of overtopping- and stage-frequency relationships and presents study results. Chapter 6 provides summary and conclusions of the study. References are listed after Chapter 6.

Appendices follow the main report. Appendix A shows tracks followed by typhoons selected for modeling. Appendix B contains a listing of station locations for storm surge calculations. Appendix $C$ gives overtopping-frequency relationship tables. Appendix D contains tables of wave parameters, setup, and ponding level that correspond to peak overtopping rates for numerical gauge locations. Appendix E shows stage-frequency relationship tables for the harbor side of Cabras Island. Corresponding tables of wave parameters and water levels by storm along the harbor side are given in Appendix F. 


\section{Storm Selection}

This chapter describes typhoons selected for modeling and the procedures used for selection. The objective was to develop a set of approximately 30 typhoons which are representative of storms affecting flooding at Apra Harbor, Guam. Coincidently, a similar study of flooding around the island of Rota, $50 \mathrm{~km}$ (31 miles) north northeast of Guam, was ongoing at the time of this study (Thompson and Scheffner, in preparation). The two islands are sufficiently close together that they are affected by the same storms. One historical storm data set served the needs of both studies.

The database of historical typhoons in the western Pacific is available on the Internet through the U.S. Navy's Joint Typhoon Warning Center (JTWC), http://www.npmoc.navy.mil/products/jtwc/best tracks/index.html. Typhoon track data covering the years 1945-97 was used. Track data is given at 6-hr intervals, including latitude and longitude of the storm eye (with 0.1-deg precision) and maximum sustained 1-min mean surface wind, in knots. Western Pacific storms are identified with prefix BWP followed by a four-digit number: the first two digits give sequential storm number for the year $(01$ is the first western Pacific storm for the year, etc.) and the second two digits give the year. For example, Typhoon Pamela (BWP0676) was the sixth western Pacific typhoon during the year 1976. These four-digit numbers are used as storm identifiers in the present study. Tropical storms originating outside the western Pacific which may affect the study area have other prefix identifiers. These other possibilities were considered, but the only such storm important in this study was Paka (BCP0597), indicating it originated in the central Pacific.

Available information about storm impacts on Guam was also gathered and reviewed to insure the storm selection process included all important historical storm events. Sources included JTWC (1991) and JTWC annual and special storm reports. This review resulted in elimination of one typhoon (Querida 1246) from consideration because the best track data differed significantly from the published description of storm track relative to Guam and Rota. Subsequent discussions with JTWC indicated that storms from before 1959 in the present data set should be considered less reliable. Other than Querida, pre-1959 storms were retained for modeling consideration because there were no inconsistencies evident in the best track files, and it was desirable to preserve the full 53-year historical database. 
Only typhoons which passed within a 200-mile square box centered on the islands of Rota and Guam and had wind speeds of 64 knots (typhoon strength) or greater within the box were considered. From these typhoons, the following considerations were applied to select a storm set for modeling. Tracks for the selected typhoons are shown in Appendix A.

Strong and weak typhoon pairs. Typhoons typically approach Guam from the east, continue moving toward the west past the island, and eventually curve toward the northwest. A small number of typhoons have approached from the south and continued moving northward past the island. Historical typhoons have no evident preference for passing on one particular side of the island and occasionally they pass directly across the island. A representative set of six strong and weak typhoon pairs (12 storms) was selected for the following cases, based on analysis of the types of tracks and storms:

a. West-moving, far north of islands.

$b$. West-moving, near north of islands.

c. West-moving, near south of islands.

d. West-moving, far south of islands.

e. North-moving, west of islands.

f. North-moving, east of islands.

Typhoons passing near islands. All remaining typhoons which passed close to the islands (basically between Guam and Rota or across either island) were selected, a total of 14 storms. These storms are considered potentially damaging because of their proximity to Guam.

Additional typhoons. The preceding criteria give a relatively complete and representative set of historical storms affecting Guam. Several other typhoons, not chosen initially by the criteria, were also reviewed to insure that all historically damaging storms were considered. These included three other candidate strong storms for "west-moving, far north of islands," and a few other typhoons with unusual tracks and some potential for generating wave and flooding impacts on Rota and/or Apra Harbor. JTWC annual reports and storm reports were consulted to see if any of these storms caused notable wave and flooding damage. Based on these considerations, two additional typhoons were added to the model set, giving a total of 28 storms.

Extreme typhoons. The impact of a typhoon on the study area at Apra Harbor can be strongly affected by typhoon track. Historical data provide a valuable record, but storms with small variations in the historical tracks would have been equally likely. For analysis of extremes, it is important to capture small variations in the most damaging storms which would have caused them to be more damaging to the study area. These are referred to as hypothetical storms. Two historical storms were considered with altered tracks to develop hypothetical cases to complete the storm data set: Paka (0597) and Olive (0163). Paka's historical track past Guam was toward due west, just north of the northern tip of 
the island. Olive's historical track was west of Guam, moving toward the north with a slight curve toward northeast. Limited modeling indicated that hypothetical variations in Paka, with track shifted slightly north and south of the actual track, had less impact on the study area than the historical Paka. Thus, any further consideration of hypothetical variations in Paka was unnecessary. Olive with track shifted 0.67 deg toward the east had sufficient impact that it was added to the storm set for modeling. Another hypothetical variation of Olive, with track shifted 0.67 deg to the west, was added for statistical balance in the modeled storm set. With the addition of two hypothetical storms, the final data set for modeling contained a total of 30 storms. The storms are listed in Table 1.

Statistical representativeness. Typhoons selected for modeling should be fairly representative of storm track statistics for the full set of typhoons passing into the box around Guam and Rota. Typhoons were classified according to their travel direction, and results are given in Table 2. The storms selected for modeling are considered sufficiently representative of the full set of storms. 


\begin{tabular}{|c|c|c|}
\hline Number & Name & Inclusive Dates \\
\hline BWP2348 & Agnes & $11 / 13 / 48-11 / 19 / 48$ \\
\hline BWP0150 & Doris & $05 / 07 / 50-05 / 13 / 50$ \\
\hline BWP0853 & Nina & $08 / 09 / 53-08 / 17 / 53$ \\
\hline BWP1953 & Alice & $10 / 12 / 53-10 / 19 / 53$ \\
\hline BWP1557 & Hester & $10 / 04 / 57-10 / 10 / 57$ \\
\hline BWP2057 & Lola & $11 / 08 / 57-11 / 21 / 57$ \\
\hline BWP1861 & Nancy & $09 / 08 / 61-09 / 16 / 61$ \\
\hline BWP2762 & Karen & $11 / 08 / 62-11 / 16 / 62$ \\
\hline BWP0163 & Olive & $04 / 27 / 63-05 / 05 / 63$ \\
\hline BWP2563 & Susan & $12 / 19 / 63-12 / 28 / 63$ \\
\hline BWP2965 & Bess & $09 / 27 / 65-10 / 05 / 65$ \\
\hline BWP3367 & Gilda & $11 / 09 / 67-11 / 18 / 67$ \\
\hline BWP2168 & Irma & $10 / 20 / 68-10 / 24 / 68$ \\
\hline BWP0571 & Amy & $04 / 30 / 71-05 / 06 / 71$ \\
\hline BWP0676 & Pamela & $05 / 14 / 76-05 / 28 / 76$ \\
\hline BWP1977 & Kim & $11 / 07 / 77-11 / 16 / 77$ \\
\hline BWP2379 & Tip & $10 / 04 / 79-10 / 19 / 79$ \\
\hline BWP2187 & Lynn & $10 / 15 / 87-10 / 27 / 87$ \\
\hline BWP0188 & Roy & $01 / 06 / 88-01 / 17 / 88$ \\
\hline BWP0289 & Andy & $04 / 13 / 89-04 / 24 / 89$ \\
\hline BWP0190 & Koryn & 01/08/90 - 01/17/90 \\
\hline BWP3190 & Russ & $12 / 13 / 90-12 / 24 / 90$ \\
\hline BWP2691 & Seth & $10 / 29 / 91-11 / 14 / 91$ \\
\hline BWP1592 & Omar & 08/20/92 - 09/06/92 \\
\hline BWP3192 & Gay & $11 / 14 / 92-11 / 30 / 92$ \\
\hline BWP3594 & Wilda & $10 / 18 / 94-11 / 01 / 94$ \\
\hline ВСР0597 & Paka & $12 / 08 / 97-12 / 21 / 97$ \\
\hline BWP2997 & Keith & $10 / 23 / 97-11 / 09 / 97$ \\
\hline 5163 & Hypothetical & Olive BWP0163 with track shifted east $0.67 \mathrm{deg}$ \\
\hline 6163 & Hypothetical & Olive BWP0163 with track shifted west $0.67 \mathrm{deg}$ \\
\hline
\end{tabular}

\section{Table 2}

\section{Statistics of Typhoon Travel Direction}

\begin{tabular}{||l|c|c|l|c||}
\hline \multirow{2}{*}{ Travel Direction } & \multicolumn{2}{|c|}{ Full Set of Storms } & \multicolumn{2}{c||}{$\begin{array}{c}\text { Storms Selected for } \\
\text { Modeling }\end{array}$} \\
\cline { 2 - 5 } & $\begin{array}{l}\text { Number of } \\
\text { Storms }\end{array}$ & Percent & $\begin{array}{l}\text { Number of } \\
\text { Storms }\end{array}$ & Percent \\
\hline \hline Moving toward west & 75 & 65 & 18 & 60 \\
\hline Moving toward north & 27 & 23 & 8 & 27 \\
\hline Moving toward west \& then north & 11 & 9 & 3 & 10 \\
\hline Moving toward east & 3 & 3 & 1 & 3 \\
\hline Total & 116 & 100 & 30 & 100 \\
\hline
\end{tabular}




\section{Modeling Approach}

Calculation of typhoon stage-frequency and overtopping relationships for Cabras Island, Apra Harbor, U.S. Territory of Guam, requires application of several standard CHL numerical models and many additional processing steps. The objective of this chapter is to explain the modeling approach and document models and procedures used in the study. An overview of the modeling approach is given in the following paragraphs. More detailed descriptions of key modeling steps are given in following sections of the chapter.

The main modeling steps are as follows. First, a Planetary Boundary Layer (PBL) wind model simulates the time-history of typhoon-induced wind and atmospheric pressure fields for each selected storm during its general proximity to the study area. The time-history of wind information serves as input to both a long-wave hydrodynamic model ADCIRC and a wind-wave model WISWAVE. The ADCIRC model provides a refined time-history of typhoon-induced water levels at the study location for each storm. The WISWAVE model provides a time-history of deepwater wave parameters in the general vicinity of Apra Harbor.

For the exposed coastal study area along Cabras Island, offshore WISWAVE information is adjusted to provide a time-history of waves incident to the nearshore coral reef. The adjustment is done with the wave-transformation model WAVTRAN. These wave parameters are subsequently matched in time with nearshore water level information from ADCIRC and used to calculate a timehistory of wave ponding over the reef and nearshore setup, runup, and overtopping. Both existing and proposed project configurations are used for the nearshore profiles. Maximum overtopping rates are extracted for each nearshore profile in each storm. The EST analysis is applied and overtopping rates are calculated for various return periods.

For the harbor side along the commercial docks, offshore WISWAVE information incident to Apra Harbor entrance is adjusted to account for the breakwater gap and propagation to the dock area. Because of the possibility of very strong typhoon winds, the dock can be exposed to a second wave component, locally-generated waves inside the harbor. The time-history of local wind from WISWAVE serves as input for calculating local wave growth inside the harbor. Both wave components, the effect of wave reflection from the dock face, and water-level information from ADCIRC are combined at the dock to give a timehistory of water level along the dock for each storm. Maximum water levels, 
including a significant wave contribution, are extracted for each storm. The EST analysis is applied to calculate water levels for various return periods.

\section{Wind and Atmospheric Pressure Field Model}

The PBL numerical model was used for simulation of typhoon-generated wind and atmospheric pressure fields. The model applies vertically averaged primitive equations of motion for predicting tropical storm wind velocities. The model includes parameterization of momentum, heat, and moisture fluxes together with surface drag and roughness formulations. Through hindcast applications, Cardone, Greenwood, and Greenwood (1992) found that the PBL model calculates accurate surface wind speeds and directions as compared to measurements collected in tropical storms over open water.

The PBL model requires a set of storm parameter snapshots for input. The snapshots consist of meteorological storm parameters that define the storm at various stages in its development or at particular times during its life. These parameters include: latitude and longitude of the storm's eye; track direction and forward speed measured at the eye; radius to maximum winds; central and peripheral atmospheric pressures; and an estimate of the geostrophic wind speed and direction. Also, the direction and speed of steering currents can be provided for representing asymmetric storms.

Storm tracks and maximum sustained 1-min mean surface winds were obtained from the JTWC database described in Chapter 2. Information contained in this database is provided at 0000-, 0600-, 1200-, and 1800-hr Greenwich Mean Time (GMT). The JTWC storm files were preprocessed to put them into the required snapshot format and to estimate other necessary parameters. Central pressure was calculated from maximum sustained 1-min mean surface wind speed using the relationship developed by Atkinson and Holliday (1977), based on data from Guam

$$
W=6.7\left(P_{a}-P_{c}\right)^{0.644}
$$

where $W$ is the maximum sustained 1-min mean surface wind speed, $P_{a}$ is the ambient pressure, and $P_{c}$ is the central pressure. Ambient pressure is taken to be $1010 \mathrm{mb}$, in accordance with Atkinson and Holliday's (1977) recommendation for the western North Pacific area.

Radius to maximum winds (RMW) is approximated by application of relationships developed in a generalized numerical model study of storm characteristics (Jelesnianski and Taylor 1973). The RMW is based on $W$ and the central pressure deficit, $P_{a}-P_{c}$. Track directions and forward speeds required by the PBL model are approximated by cubic spline interpolation at hourly intervals from 6 -hr coordinate positions provided in the database. Geostrophic wind speeds were specified as $6 \mathrm{~m} / \mathrm{s}$. 
The spatial area covered by a tropical storm at a given time is specified in the PBL model to correspond to a set of nodes on a numerical grid. Wind velocities and atmospheric pressure values are computed at each node in the grid. Whereas some models employ a fixed grid system to simulate a tropical storm (i.e., stationary grid with a moving storm), the PBL model simulates a typhoon as a stationary storm with a moving grid. Forward motion of the storm is calculated as the vector sum of the forward and rotational velocity vector components. The numerical grid is moved with the storm at the calculated forward velocity at each time-step so that the grid center always coincides with the storm center.

The distribution of wind speed and radial change in wind speed varies spatially within a tropical storm such that higher spatial resolution of the wind field is required in the central region of the storm, whereas coarser resolution suffices on the outer areas. To provide spatially-graded resolution of the wind field, a nested gridding technique is applied consisting of five layers or subgrids. The grid nesting is applied such that all subgrids contain the same number of nodes. However, the spatial coverage and resolution differs and is successively graded. Each subgrid is composed of 21 by 21 nodes in the $\mathrm{x}$ - and $\mathrm{y}$-directions, respectively. The centers of all subgrids lie on node $(11,11)$, defined at the eye of the tropical storm. For this study, the subgrid with the finest resolution had an incremental distance of $5 \mathrm{~km}$ ( 3.1 miles) between nodes and covered an area of $10,000 \mathrm{sq} \mathrm{km}$ (3,861 square miles). Incremental distances for the remaining subgrids were $10,20,40$, and $80 \mathrm{~km}(6.2,12.4,24.9$, and 49.7 miles $)$ and their areas of coverage were $40,000,160,000,640,000$, and 2,560,000 sq km $(15,444$, $61,776,247,104$, and 988,428 square miles), respectively.

For each snapshot, the equations of motion are first solved for the subgrid covering the greatest area. Computed wind velocities are then applied as boundary conditions on the second-largest grid, and the equations are solved again. This procedure is followed for the remaining grids where wind fields are computed on successively smaller grids. Thus, the nested grid technique provides wind field information over a wide spatial area while sufficient grid resolution is provided to accurately compute winds in the vicinity of the tropical storm eye.

After all snapshots have been processed, hourly wind and atmospheric pressure fields are interpolated using a nonlinear blending algorithm which produces a smooth transition from one snapshot to the next. Hourly wind and pressure fields are then interpolated from the PBL grid onto the hydrodynamic or wave model grid and subsequently stored for use by those models. Wind velocities produced by the PBL model represent an averaging time of 30-60 min, which is appropriate for wave and storm surge modeling (Thompson and Cardone 1996).

\section{Storm Surge Model}

The ADvanced CIRCulation (ADCIRC) numerical model was applied for simulation of the long-wave hydrodynamic processes in the study area. The model calculates a two-dimensional, depth-integrated finite-element solution of 
the Generalized Wave-Continuity Equation (GWCE). Fundamental components of the GWCE are the depth-integrated continuity and Navier-Stokes equations for conservation of mass and momentum. The assumption of incompressibility and the Boussinesq and hydrostatic pressure approximations were applied. The primitive, nonconservative form of the governing equations, given in spherical coordinates, as applied in the model are (Flather 1988; Kolar et al. 1993)

$$
\begin{aligned}
& \frac{\partial \zeta}{\partial t}+\frac{1}{R \cos (\phi)}\left\{\frac{\partial U D}{\partial \varphi}+\frac{\partial[U V \cos (\phi)]}{\partial \phi}\right\}=0 \\
& \frac{\partial U}{\partial t}+\frac{1}{R \cos (\phi)} U \frac{\partial U}{\partial \varphi}+\frac{1}{R} V \frac{\partial U}{\partial \phi}-\left[\frac{\tan (\phi)}{R} U+f\right] V \\
& =-\frac{1}{R \cos (\phi)} \frac{\partial}{\partial \varphi}\left[\frac{P_{S}}{\rho_{0}}+g(\zeta-\xi)\right]+\frac{\tau_{S \varphi}}{\rho_{0} D}-\tau_{*} U \\
& \frac{\partial V}{\partial t}+\frac{1}{R \cos (\phi)} U \frac{\partial V}{\partial \varphi}+\frac{1}{R} V \frac{\partial V}{\partial \phi}-\left[\frac{\tan (\phi)}{R} U+f\right] U \\
& =-\frac{1}{R} \frac{\partial}{\partial \varphi\left[\frac{P_{S}}{\rho_{0}}+g(\zeta-\xi)\right]+\frac{\tau_{S \phi}}{\rho_{0} D}-\tau_{*} V}
\end{aligned}
$$

where $t$ is time, $\varphi$ is degrees longitude (east of Greenwich is taken positive), $\phi$ is degrees latitude (north of the equator is taken positive), $\zeta$ is the free-surface elevation relative to the geoid, $U$ is the depth-averaged velocity component parallel to the east-west axis, $V$ is the depth-averaged velocity component parallel to the north-south axis, $R$ is the radius of the earth, $D=\zeta+h$ is the total water-column depth, $h$ is the ambient depth relative to the geoid, $f=2 \Omega \cos (\phi)$ is the Coriolis parameter, $\Omega$ is the angular speed of the earth's rotation, $P_{s}$ is the atmospheric pressure at the free surface, $g$ is the acceleration due to gravity, $\xi$ is the effective Newtonian equilibrium tide potential, $\rho_{0}$ is the reference density of water, $\tau_{s \varphi}$ and $\tau_{s \phi}$ are the applied free-surface stresses, and $\tau_{*}$ is the bottom stress given by $C_{f}\left(U^{2}+V^{2}\right)^{1 / 2} / D$ where $C_{f}$ is the bottom-friction coefficient.

The time-differentiated form of the conservation of mass equation is combined with a space-differentiated form of the conservation of momentum equation to develop the GWCE (Westerink et al. 1992) given by 


$$
\begin{aligned}
& \frac{\partial^{2} \zeta}{\partial t^{2}}+\tau_{0} \frac{\partial \zeta}{\partial t}-\frac{1}{R \cos (\phi)} \frac{\partial}{\partial \varphi}\left[\frac{1}{R \cos (\phi)}\left(\frac{\partial(D U U)}{\partial \varphi}+\frac{\partial(D U V \cos (\phi))}{\partial \phi}\right)-U V D \frac{\tan (\phi)}{R}\right] \\
& \left\{-2 \omega \sin (\phi) D V+\frac{D}{R \cos (\phi)} \frac{\partial}{\partial \varphi}\left[g(\zeta-\alpha \xi)+\frac{P_{S}}{\rho_{0}}\right]+\tau_{*} D U-\tau_{0} D U-\frac{\tau_{S \varphi}}{\rho_{0}}\right\} \\
& -\frac{1}{R} \frac{\partial}{\partial \phi}\left\{\frac{1}{R \cos (\phi)}\left[\frac{\partial D V V}{\partial \varphi}+\frac{\partial D V V \cos (\phi)}{\partial \phi}\right]+U U H \frac{\tan (\phi)}{R}+2 \omega \sin (\phi) D U\right\} \\
& -\frac{1}{R} \frac{\partial}{\partial \phi}\left\{\frac{D}{R} \frac{\partial}{\partial \phi}\left[g(\zeta-\alpha \xi)+\frac{P_{S}}{\rho_{0}}\right]+\left(\tau_{*}-\tau_{0}\right) D V-\frac{\tau_{S \phi}}{\rho_{0}}\right\} \\
& -\frac{\partial}{\partial t}\left[\frac{V D}{R} \tan (\phi)\right]-\tau_{0}\left[\frac{V D}{R} \tan (\phi)\right]=0
\end{aligned}
$$

The ADCIRC model solves the GWCE (Equation 5) in conjunction with the primitive momentum equations given by Equations 3 and 4 .

The GWCE-based solution scheme eliminates several problems associated with finite-element models that solve the primitive forms of the continuity and momentum equations (i.e., Navier-Stokes equations), including spurious modes of oscillation and artificial damping of the tidal signal. Forcing functions include time-varying water-surface elevation, wind stress, atmospheric pressure, and the Coriolis effect.

The computational grid developed for this study is a large-domain circular grid with a radius of $4 \mathrm{deg}$ (276 miles) and center at $145^{\circ}$ east longitude and $14^{\circ}$ north latitude. The islands of Guam and Rota are located in the central region of the grid. The large scale of the grid has two main advantages. First, the tidal forcing boundaries are far from the region of interest such that island shorelines are free from boundary effects. Second, because typhoons are largescale atmospheric phenomena, a large-domain grid is preferred to maximize the interaction of the horizontal storm area with the computational grid, as well as the storm track.

The grid developed for this study is shown in Figure 5. Grid resolution is coarser in the open regions with increasing resolution toward the shore. Grid parameters and range of scale of element sizes contained in the grid are given in Table 3. Three Mariana Islands north of Guam were sufficiently large and close that they are included in the grid: Rota, Saipan, and Tinian. The grid around these islands was specified to be much coarser than the region surrounding Guam. Initially, inclusion of detailed coastline and bathymetry around Rota was an objective in developing the grid, so that one grid would serve for studies at both Apra Harbor and Rota. However, this objective proved to be impractical. 


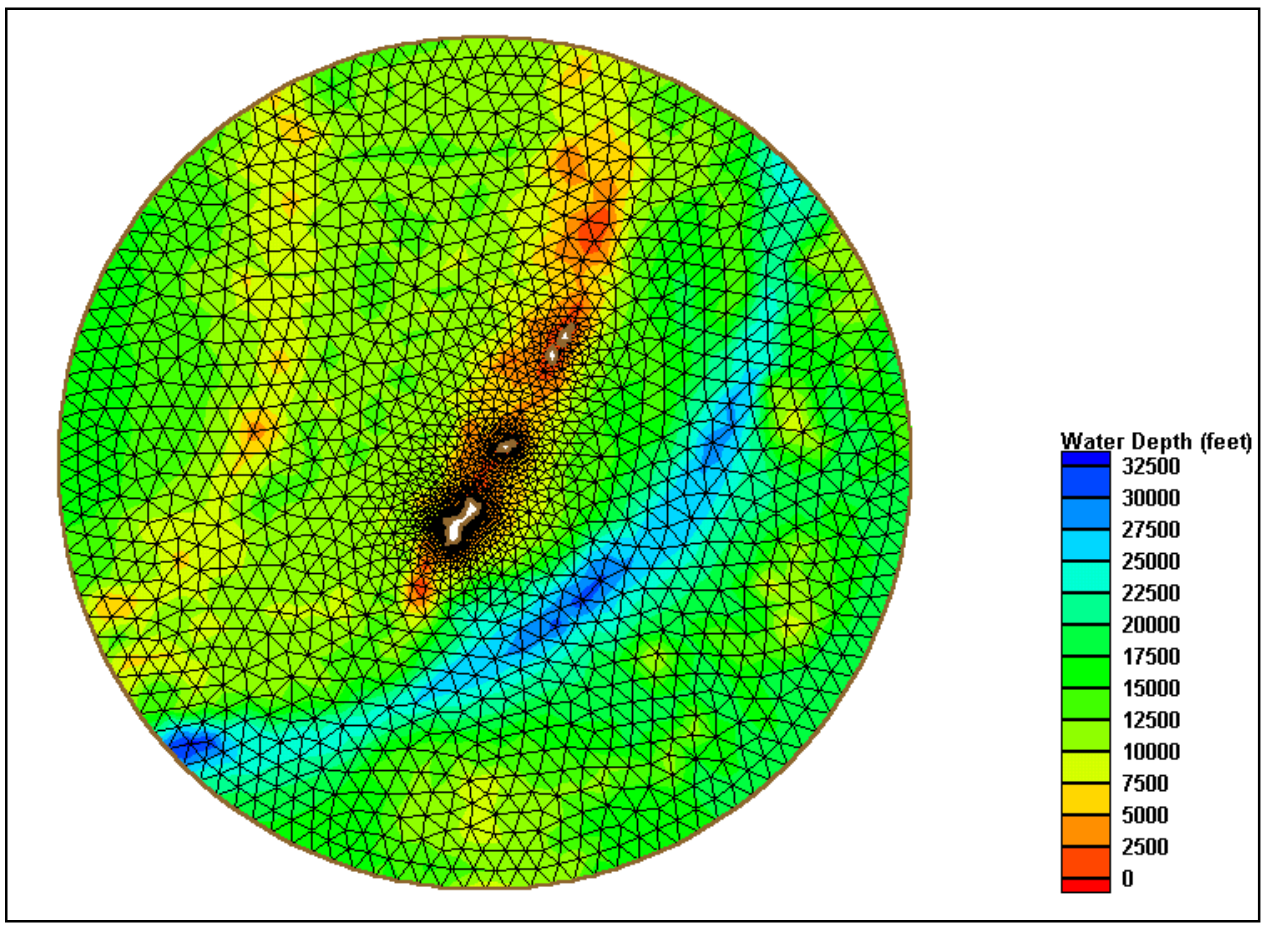

Figure 5. Complete computational grid for Guam study (To convert feet to meters, multiply by 0.3048 )

\begin{tabular}{|c|c|}
\hline Parameter & Value \\
\hline Maximum element area & $400,173,057 \mathrm{~m}^{2}\left(4,307,322,182 \mathrm{ft}^{2}\right)$ \\
\hline Minimum element area & $570 \mathrm{~m}^{2}\left(6,132 \mathrm{ft}^{2}\right)$ \\
\hline Ratio of maximum to minimum element areas & 702,433 \\
\hline Number of elements & 15,301 \\
\hline Number of nodes & 8,410 \\
\hline Center longitude and latitude & $145 \mathrm{E}, 14 \mathrm{~N}$ \\
\hline Circular grid radius & $4 \mathrm{deg}$ \\
\hline
\end{tabular}

The finest grid resolution is around the study area. Reefs, shallow areas, and embayments are finely resolved in and near the study area so that the hydrodynamics can be accurately calculated in these regions. Details of the grid around Guam are shown in Figure 6. Figure 7 shows detail of Apra Harbor and the study area. Because of the fine grid resolution in reef areas coupled with the extreme hydrodynamic conditions (strong currents and rapid change in water level) associated with the storms, a time-step of $5 \mathrm{sec}$ was required for model runs. 


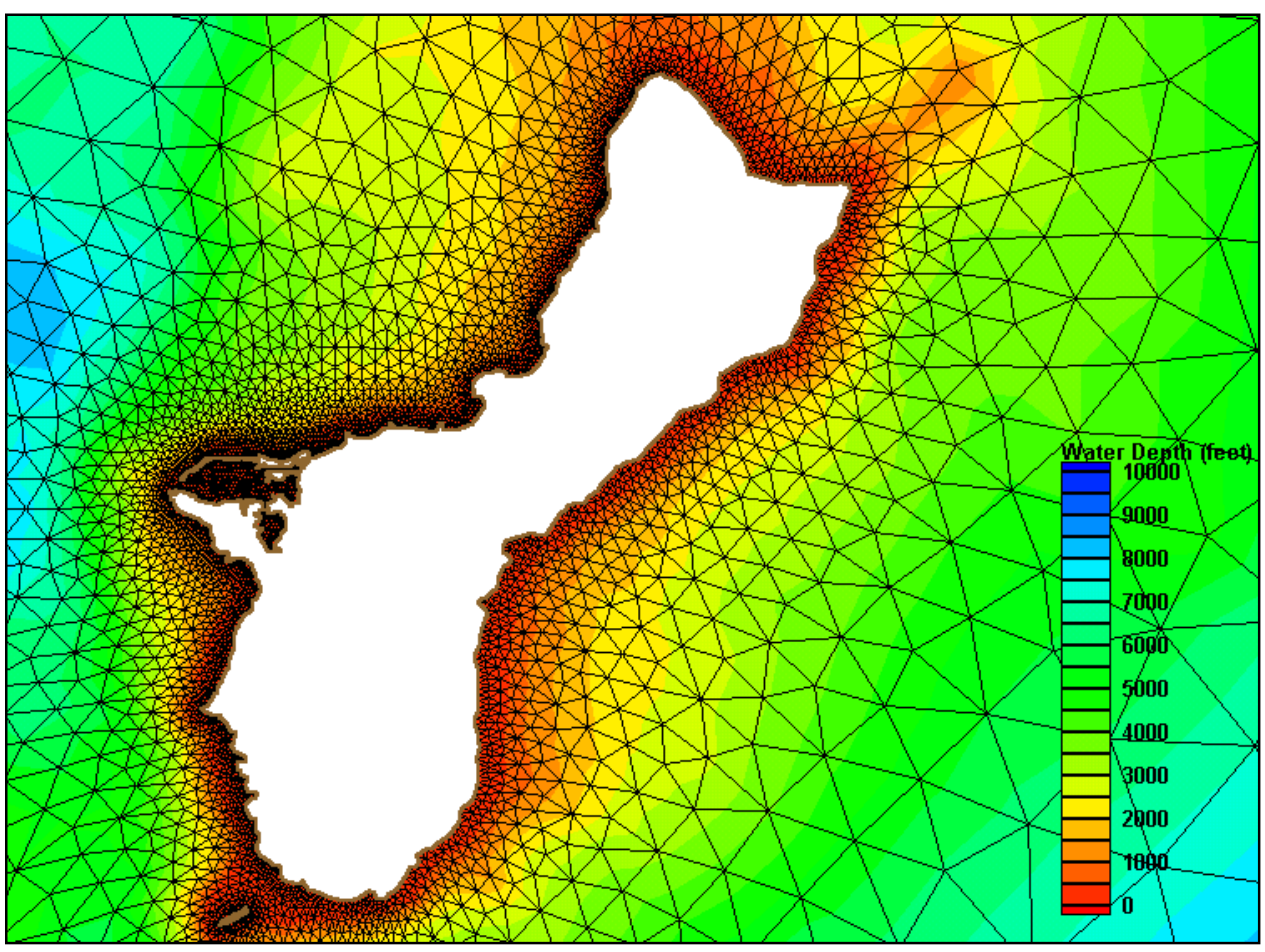

Figure 6. Computational grid showing detail for Guam (To convert feet to meters, multiply by 0.3048 )

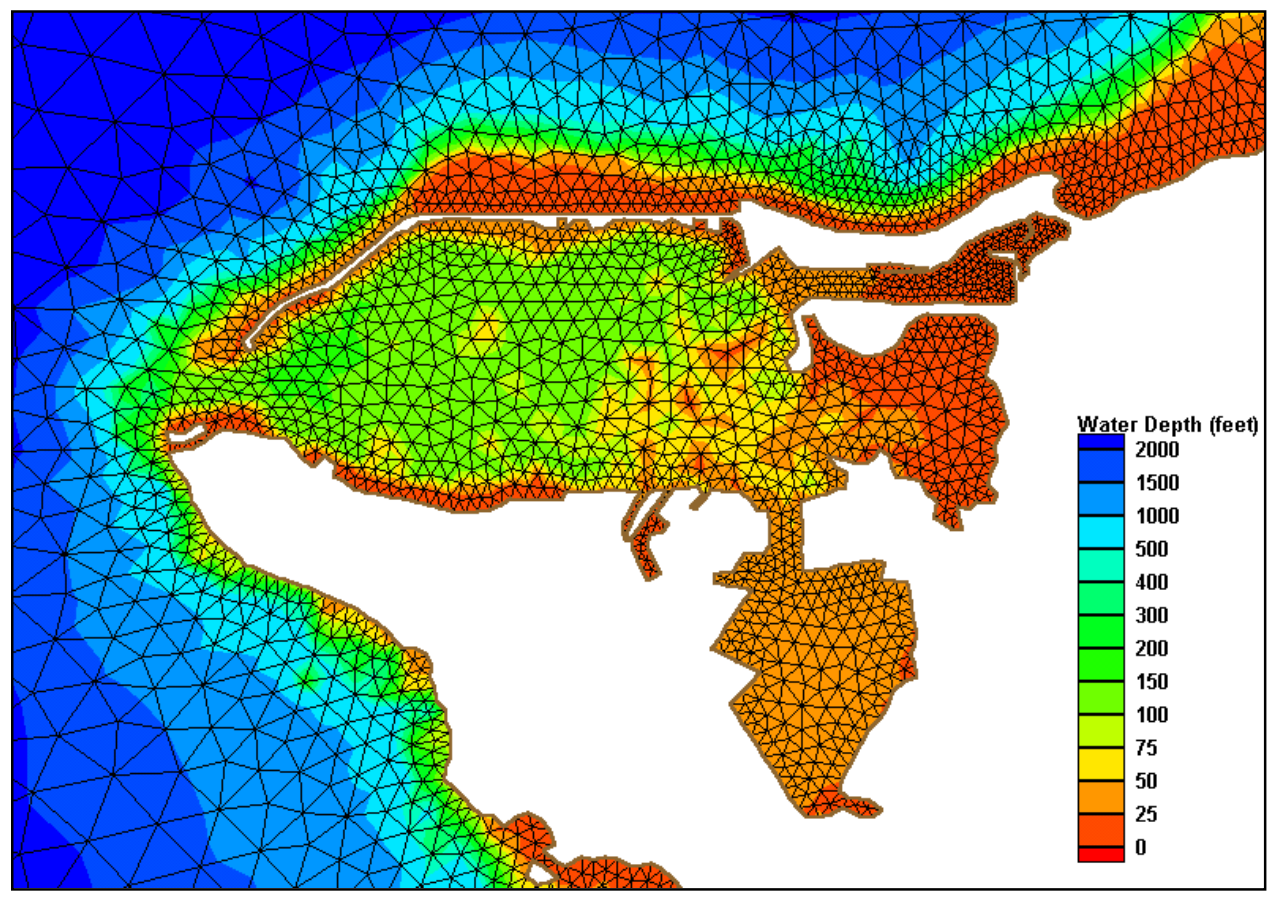

Figure 7. Computational grid showing detail for Apra Harbor (To convert feet to meters, multiply by 0.3048 ) 
Several data sources were accessed for development of the computational grid. Initially, shoreline and bathymetry data were obtained from the U.S. Department of Defense Digital Nautical Chart database (National Imagery and Mapping Agency 1999). The digital database was supplemented in offshore areas by digitizing points and contours from National Oceanic and Atmospheric Administration (NOAA) Chart \#81004 and DMA Chart \#81025 as needed to get a complete representation. Bathymetry around Guam and detailed bathymetry around Apra Harbor were supplemented using NOAA Charts \#81048 and \#81054. The Rota Island boundary and coastal bathymetry, which were absent from the NIMA database, were digitized from NOAA Chart \#81063. Grid depths are referenced to mean sea level (msl).

Tidal elevations specified at the open-water boundary were calculated from tidal amplitudes and phases contained in the LeProvost World Tidal Constituent Database, which provides constituent data at 1-deg increments in latitude and longitude. A bilinear interpolation algorithm was applied to calculate tidal amplitudes and phases at 118 open boundary nodes. The six tidal constituents applied at the open boundaries were: $\mathrm{M}_{2}, \mathrm{~S}_{2}, \mathrm{~N}_{2}, \mathrm{P}_{1}, \mathrm{O}_{1}$, and $\mathrm{K}_{1}$.

\section{Wave and Wave Transformation Models}

Deepwater wave fields were calculated by application of the Wave Information Studies Wave (WISWAVE) model (Hubertz 1992; Resio and Perrie 1989). This model is a second-generation discrete directional spectral wave model in which the spectral wave computations are based on the integration of energy over the discrete frequency spectrum. Model output includes time series of significant wave height, peak (dominant) or mean wave period, and mean wave direction. Peak or dominant wave periods are not integral quantities in that they are not derived by summation over the spectrum. Peak period is defined as the period associated with the midband frequency, or that frequency band containing the largest spectral energy density. Mean wave period is an energy-weighted quantity integrated over all user-specified frequencies of interest. Model input includes a rectilinear computational grid, with water depths specified at each node, and wind speed and direction over the grid domain.

Application of the wave model required a grid resolution such that calculation points could be distributed around and near to the coasts of Guam and Rota so that representative wave conditions would be captured for all sides of the islands needed in the studies. To meet this requirement, a grid with constant spacing of $0.083 \mathrm{deg}$ was developed. For wave modeling at this scale, deepwater can be applied over the grid. The islands of Guam and Rota were specified as land in the grid for accurate calculation of wave sheltering and refraction. At this grid scale, Guam is represented by 22 land points and Rota by 6 land points. Details of the grid are given in Table 4. 


\begin{tabular}{|c|c|}
\hline \multicolumn{2}{|l|}{$\begin{array}{l}\text { Table } 4 \\
\text { WISWAVE Grid Parameters }\end{array}$} \\
\hline Parameter & Value \\
\hline Longitude limits & $141.0333 \mathrm{E}, 149.0333 \mathrm{E}$ \\
\hline Latitude limits & $10.0333 \mathrm{~N}, 18.0333 \mathrm{~N}$ \\
\hline Cell side length & $0.083 \mathrm{deg}$ \\
\hline Total number of nodes & 9409 \\
\hline Number of nodes in north-south direction & 97 \\
\hline Number of nodes in east-west direction & 97 \\
\hline
\end{tabular}

Wind forcing for the wave model was calculated by application of the PBL model, as discussed previously. Wind speed and direction were calculated for each point on the wave grid at 1-hr intervals.

Deepwater wave parameters calculated by the wave model were stored at eight stations around Apra Harbor and the west coast of Guam and 24 stations surrounding Rota for each of the 30 storms in the training set (described in Chapter 2). A list of these stations is given in Table 5. The duration of wave simulations corresponded to the time coverage of each storm in the JTWC database. Thus, each storm simulation began when the storm center was well outside the WISWAVE grid and ended with the storm cell well beyond the grid. Wave parameters were stored at 1-hr intervals.

Deepwater waves produced by WISWAVE were transformed to the study area by application of the nearshore wave transformation model WAVTRAN (Jensen 1983; Gravens, Kraus, and Hanson 1991). The WAVTRAN model calculates spectral transformation of waves during propagation from one depth to another shallower depth, taking into account shoreline orientation and wave sheltering. The model assumes that sea and swell waves have an energy spectrum that follows the Texel, MARSEN, ARSLOE (TMA) spectral form (Bouws et al. 1985). Directional spread is calculated by $4^{\text {th }}$ and $8^{\text {th }}$ power cosine functions. Wave transformation calculation is dependent on the shoreline orientation because bottom contours are assumed parallel to the shoreline. If wave sheltering is included, waves coming from directions specified by a sheltered angle band are deleted from the spectrum. Details of the model application for this study are given in Chapter 5.

\section{Wave Runup and Overtopping}

In the project area along the north side of Cabras Island, the present study differs from previous CHL studies in two important ways. First, the primary study result is a rate of overtopping of the existing seawall, whereas previous studies have only been concerned with water levels and, in some cases, runup elevations on a continuous nearshore profile. Second, plan nearshore profiles include a low-crested berm designed specifically to reduce overtopping. 


\begin{tabular}{|c|c|c|}
\hline \multicolumn{3}{|c|}{$\begin{array}{l}\text { Table } 5 \\
\text { Deepwater Wave Stations }\end{array}$} \\
\hline Station Number & Latitude, deg N & Longitude, deg $\mathrm{E}$ \\
\hline 1 & 13.37 & 144.45 \\
\hline 2 & 13.45 & 144.45 \\
\hline 3 & 13.53 & 144.45 \\
\hline 4 & 13.45 & 144.53 \\
\hline 5 & 13.53 & 144.53 \\
\hline 6 & 13.62 & 144.53 \\
\hline 7 & 13.53 & 144.62 \\
\hline 8 & 13.62 & 144.62 \\
\hline 9 & 14.12 & 144.95 \\
\hline 10 & 14.20 & 144.95 \\
\hline 11 & 14.03 & 145.03 \\
\hline 12 & 14.12 & 145.03 \\
\hline 13 & 14.20 & 145.03 \\
\hline 14 & 14.28 & 145.03 \\
\hline 15 & 13.95 & 145.12 \\
\hline 16 & 14.03 & 145.12 \\
\hline 17 & 14.28 & 145.12 \\
\hline 18 & 14.37 & 145.12 \\
\hline 19 & 13.95 & 145.20 \\
\hline 20 & 14.03 & 145.20 \\
\hline 21 & 14.28 & 145.20 \\
\hline 22 & 14.37 & 145.20 \\
\hline 23 & 13.95 & 145.28 \\
\hline 24 & 14.03 & 145.28 \\
\hline 25 & 14.28 & 145.28 \\
\hline 26 & 14.37 & 145.28 \\
\hline 27 & 14.03 & 145.37 \\
\hline 28 & 14.12 & 145.37 \\
\hline 29 & 14.20 & 145.37 \\
\hline 30 & 14.28 & 145.37 \\
\hline 31 & 14.12 & 145.45 \\
\hline 32 & 14.20 & 145.45 \\
\hline
\end{tabular}

Nearshore methodologies applied in previous CHL studies do not adequately accommodate the new requirements of the present study. In the feasibility report for this project, the U.S. Army Engineer Division, Pacific Ocean (1995) used a widely accepted approach for runup and overtopping on sloping beaches to analyze the existing condition. Overtopping relationships developed by Ward and Ahrens (1992) were used to analyze the plan condition. Ward and Ahrens conducted laboratory experiments with a variety of different structural coastal 
protection configurations. Some configurations included low-crested berms. No configurations ideally matched the plan configuration for Cabras Island, but USAED, Pacific Ocean (1995) provided a reasonable initial assessment of the plan's impact on overtopping rates by considering several test configurations with berm features.

A method for estimating storm wave runup and overtopping on berm profiles has been developed for application to dikes in The Netherlands (van der Meer and Janssen 1994; De Waal and van der Meer 1992). The method has general applicability and it was chosen for application in the present study. Based on extensive laboratory testing, it inherently includes important irregular wave effects on overtopping rates. It provides a well-tested, unified methodology for evaluating both existing and plan beach profiles along Cabras Island. A few of the existing profiles include a natural berm which can be expected to function similarly to the plan berm. The van der Meer and Janssen methodology, henceforth abbreviated as $\mathrm{VJ}$, can realistically accommodate those profiles. The VJ methodology is described in the remainder of this section.

A distinction is made between breaking and nonbreaking wave conditions, as identified by the surf similarity parameter or breaker parameter

$$
\xi_{o p}=\frac{\tan \alpha}{\sqrt{s_{o p}}}
$$

where

$$
\begin{aligned}
\xi_{o p} & =\text { breaker parameter } \\
\alpha & =\text { nearshore slope angle } \\
S_{o p} & =\text { wave steepness; }=2 \Pi H_{s} / g T_{p}^{2} \\
g & =\text { acceleration due to gravity } \\
H_{s} & =\text { significant wave height near toe of the slope } \\
T_{p} & =\text { peak period of the wave spectrum }
\end{aligned}
$$

When $\xi_{o p}<2$, waves are considered to be breaking on the slope. Otherwise, they are considered to be nonbreaking.

The overtopping rate for breaking waves is calculated from an empirical relationship between dimensionless overtopping rate

$$
Q_{b}=\frac{q}{\sqrt{g H_{s}^{3}}} \sqrt{\frac{S_{o p}}{\tan \alpha}}
$$

and dimensionless crest height of the beach profile 


$$
R_{b}=\frac{R_{c}}{H_{s}} \frac{\sqrt{s_{o p}}}{\tan \alpha} \frac{1}{\gamma_{b} \gamma_{h} \gamma_{f} \gamma_{\beta}}
$$

where

$$
\begin{aligned}
Q_{b} & =\text { dimensionless overtopping rate for breaking waves } \\
q & =\text { average overtopping rate (in cfs per ft width) } \\
R_{b} & =\text { dimensionless crest of beach profile with breaking waves } \\
R_{c} & =\text { crest height of beach profile above still-water line } \\
\gamma_{b} & =\text { reduction factor for influence of a berm } \\
\gamma_{h} & =\text { reduction factor for influence of shallow foreshore } \\
\gamma_{f} & =\text { reduction factor for influence of roughness } \\
\gamma_{\beta} & =\text { reduction factor for influence of angle of wave attack }
\end{aligned}
$$

The relationship recommended by $\mathrm{VJ}$ for design is

$$
Q_{b}=0.06 e^{-4.7 R_{b}}
$$

Similar relationships are available for nonbreaking wave conditions, as follows

$$
\begin{aligned}
& Q_{n}=\frac{q}{\sqrt{g H_{s}^{3}}} \\
& R_{n}=\frac{R_{c}}{H_{s}} \frac{1}{\gamma_{b} \gamma_{h} \gamma_{f} \gamma_{\beta}}
\end{aligned}
$$

where

$Q_{n}=$ dimensionless overtopping rate for nonbreaking waves

$R_{n}=$ dimensionless crest of beach profile with nonbreaking waves

and the recommended design relationship for nonbreaking waves is

$$
Q_{n}=0.2 e^{-2.3 R_{n}}
$$

There are several constraints on the previous relationships given by $\mathrm{VJ}$, based on the range of conditions tested and the nature of the laboratory testing. The product of all $\gamma$ reduction factors is limited to a minimum value of 0.5 . The accepted range of application of the breaking wave relationship is for $0.3<R_{b}<2$. 
The four reduction factors involved in calculating overtopping rate are discussed further in the following subsections.

\section{Reduction factor for influence of a berm}

The presence of a berm in the nearshore profile can significantly reduce runup and overtopping relative to a continuously sloped profile. The reduction factor which accounts for the influence of a berm in the nearshore profile is given by $\mathrm{VJ}$ as

$$
\gamma_{b}=1-r_{B}\left(1-r_{d h}\right)
$$

where

$r_{B}=$ factor based on berm width

$r_{d h}=$ factor based on berm location relative to the still-water level (swl)

The factor $\gamma_{b}$ is confined to the range $1.0 \geq \gamma_{b} \geq 0.6$.

The factor based on berm width is given by

$$
r_{B}=1-\frac{\tan \alpha_{e q}}{\tan \alpha}
$$

where

$\tan \alpha_{e q}=$ equivalent slope gradient to represent berm width effects

$\tan \alpha=$ representative slope gradient without consideration of berm

Equivalent slope gradient is determined as the slope of a straight line between two points on the nearshore profile: one point is at elevation $H_{s}$ above the most seaward point of the berm; the other point is at elevation $H_{s}$ below the most seaward point of the berm (Figure 8). Equivalent slope gradient is independent of water level.

Representative slope gradient is determined by extending an imaginary line up from the most seaward point of the berm (Figure 9). Slope of the imaginary line is equal to the slope of the nearshore profile shoreward of the berm. Effectively, the berm is removed from the nearshore profile. Representative slope gradient is defined as the slope of a straight line between two points: one point is at elevation $H_{s}$ below the swl; the other point is at elevation $H_{s}$ above the swl. If the upper elevation is higher than that of the most seaward point on the berm, then the upper point is taken on the imaginary line. This approach is based on the consideration that the slope most influencing wave runup is that within one significant wave height above and below the swl. 


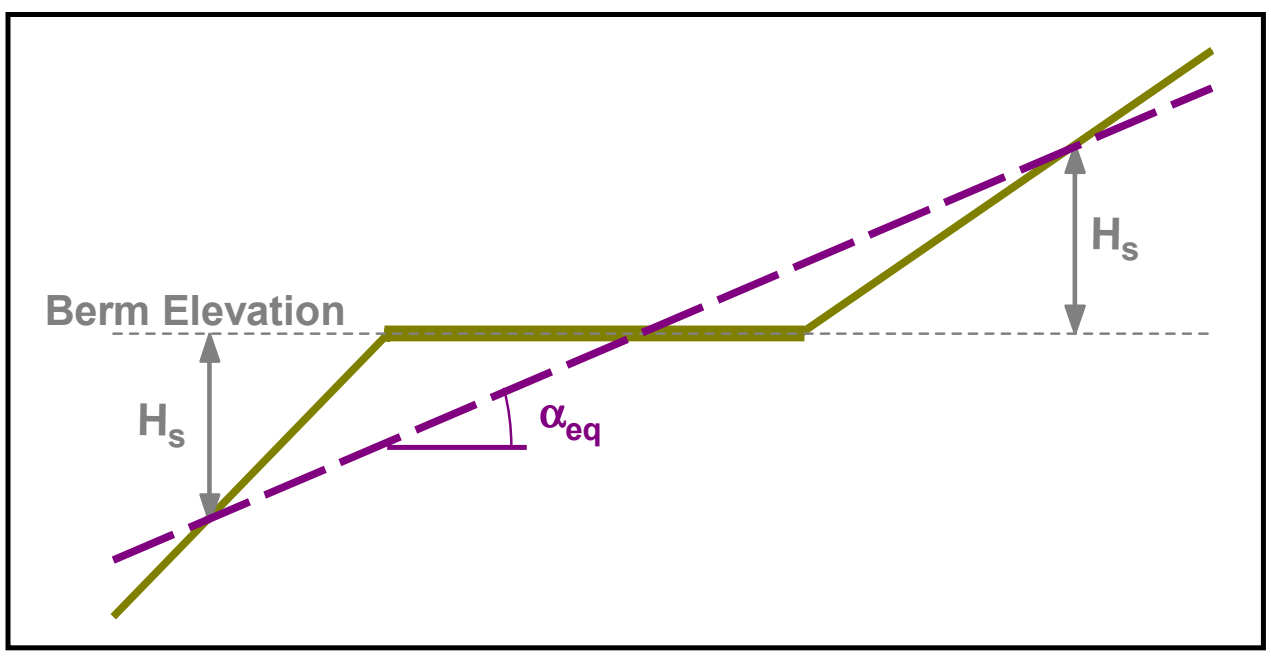

Figure 8. Definition sketch, equivalent slope for berm profile

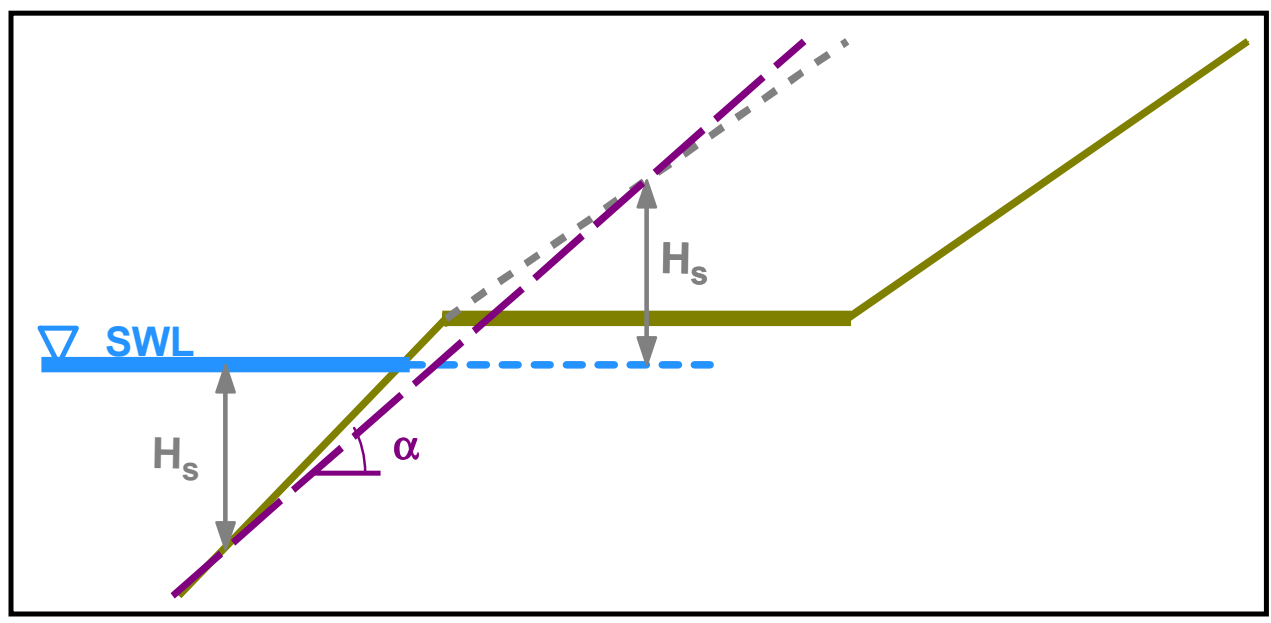

Figure 9. Definition sketch, representative slope for berm profile

The factor based on berm location relative to the swl is given by

$$
r_{d h}=0.5\left(\frac{d_{h}}{H_{s}}\right)^{2}
$$

where

$d_{h}=$ elevation difference between most seaward berm point and swl

The factor $r_{d h}$ is confined to the range $1 \geq r_{d h} \geq 0$.

The impact of a berm on the value calculated for $\gamma_{b}$ by the preceding procedure depends in physically meaningful ways on the particular berm configuration. The factor $r_{d h}$ has maximum impact when the swl coincides with the 
elevation of the most seaward berm point. As the swl deviates from this elevation, $r_{d h}$ soon reaches a value of one and the berm has no further impact on runup and overtopping. When swl is near the elevation of the seaward berm point, then berm width has an additional effect in reducing runup and overtopping. As berm width increases, the value of $r_{B}$ approaches one, and the overall reduction factor $\gamma_{b}$ becomes smaller.

\section{Reduction factor for influence of shallow foreshore}

When water depth immediately seaward of the nearshore profile for runup and overtopping calculations is relatively shallow, high waves in the train of irregular incident waves will break. Thus, waves attacking the nearshore profile will be somewhat diminished due to the presence of a shallow foreshore. VJ suggest the following approximation for the reduction factor:

$$
\gamma_{h}=1-0.03\left(4-\frac{d_{s}}{H_{s s}}\right)^{2}
$$

where

$$
\begin{aligned}
d_{s} & =\text { water depth at toe of nearshore profile } \\
H_{s s} & =\text { significant wave height at toe of nearshore profile }
\end{aligned}
$$

If $d_{s} / H_{s s} \geq 4$, then $\gamma_{h}=1.0$.

\section{Reduction factor for influence of roughness}

Runup and overtopping on a rough slope is reduced relative to a comparable smooth slope. This effect has traditionally been represented by a factor representing the ratio of rough slope runup to smooth slope runup. A table of reduction factors, $\gamma_{f}$, is given by $\mathrm{VJ}$ for various types of slope. This factor is comparable to reduction factors given in the Shore Protection Manual (1984) in Table 7-2, Chapter 7, Volume II. VJ recommend that this factor be set to one for cases in which the breaker parameter is relatively large, that is, $\gamma_{f}=1$ when $\xi_{o p} \geq 4$.

\section{Reduction factor for influence of angle of wave attack}

Waves approaching perpendicular to a nearshore profile can be expected to cause higher runup and overtopping than waves approaching from an oblique angle. For the case of long-crested waves approaching within 30 deg of normal to shore, VJ suggest that obliquity has no impact and these cases can be treated as directly approaching. For short-crested waves, even small oblique angles of 
approach can be considered to reduce runup and overtopping. For overtopping, $\mathrm{VJ}$ recommend a short-crested wave reduction factor of

$$
\gamma_{\beta}=1-0.0033 \beta
$$

where

$\beta=$ angle between wave approach direction and shore normal, in deg

\section{Harbor Side Analysis}

Flooding in the proposed project area can be affected by processes on the south side of Cabras Island, along the commercial docks, as well as by processes along the ocean side. Harbor side considerations are somewhat different than those along the ocean side. Key concerns are waves at the dock face combined with elevated swl during typhoons, which can potentially cause water to rise up onto the dock apron. Typhoon effects on water level for the dock area are available from ADCIRC modeling, since the model grid includes a detailed representation of the commercial harbor.

Waves arriving at the dock are principally from two sources. Waves generated by typhoon winds in deep offshore areas can propagate through the entrance gap between Glass Breakwater and Orote Peninsula, and continue across the harbor to the dock area. The second source is waves generated inside the harbor by local typhoon winds. Although harbor fetches are short, they are sufficiently long that winds during the intense part of a nearby typhoon can generate significant wave heights of up to $1.5 \mathrm{~m}(5 \mathrm{ft})$ or more. The approach for estimating waves from these sources is discussed in the following subsections.

\section{Wave propagation through harbor entrance}

Wave propagation through the harbor entrance is estimated using information from Figures II-7-14 through II-7-17 in Headquarters, U.S. Army Corps of Engineers (2001). The figures give diffraction coefficients for normally incident waves propagating through a breakwater gap of various widths. Gap width is expressed as a multiple of the incident wavelength. The figures are based on tests with directionally spread irregular waves. Considering exposure of the dock area to waves coming through the entrance, the relatively uniform water depth in the harbor along the path between dock and entrance, and the configuration of the entrance gap, these diffraction figures are judged to be a reasonable approximation.

To automate diffraction analysis for application to the time-history of typhoon conditions, several adaptations were necessary. First, the figures represent only waves normally incident to the breakwater gap. In a typical manual analysis of oblique wave approach, the diffraction diagram would effectively be 
rotated so that waves are normally incident to a fictitious entrance gap. The fictitious gap is centered on the actual gap but with width reduced to the projection of the actual gap onto a line perpendicular to the incident wave direction. This approach is inconvenient for automation because much of the diffraction diagram would need to be accessible to accommodate the variety of incident waves in a typhoon time-history.

A more convenient approach for oblique waves is to take an appropriately reduced wave height and apply it as a normally incident wave. Then diffraction diagrams can be applied directly and the dock area always falls in a very localized part of the diagrams. The reduction factor used for oblique waves is the square of the cosine of the angle between the actual wave direction and normal incidence. For incident wave directions of importance, this approach results in diffraction coefficients similar to those from the manual analysis previously discussed.

A Fortran program HARBOR was written to calculate the time-history of significant wave height at the dock due to diffraction through the harbor entrance. A diffraction coefficient look up table was compiled for various gap widths and locations along the dock. Diffraction diagrams for sea conditions with large directional spread $\left(s_{\max }=10\right)$ were used. Interpolation between figures was used to give a diffraction coefficient representative of the actual relative gap width for each case.

\section{Local wave generation inside Apra Harbor}

Waves generated inside Apra Harbor by typhoon winds were calculated with the relationship (Headquarters, U.S. Army Corps of Engineers 1989)

$$
H_{\text {sloc }}=0.0177 U_{c}^{1.23} F^{0.5}
$$

where

$$
\begin{aligned}
H_{\text {sloc }} & =\text { significant height due to local wind wave generation, in feet } \\
U_{c} & =\text { local wind speed, in miles per hour } \\
F & =\text { local fetch, in miles }
\end{aligned}
$$

This relationship was included in the Fortran program HARBOR. Local fetch distances from the dock area were included for 10-deg increments in wind approach direction. Since the time-history of local wind speed is available from PBL wind model runs discussed previously, a time-history of locally generated significant wave height at the dock can be calculated. 


\section{Combined impact at dock}

Wave propagation through Apra Harbor entrance and diffraction in the harbor occurs simultaneously with local wave generation inside the harbor. Significant wave height at the dock resulting from these two components can be estimated by assuming that the total energy density in the sea surface is equal to the sum of the energy densities due to each wave component. Since energy density is proportional to wave height, this gives:

$$
H_{\text {sdock }}=\sqrt{H_{\text {sdiff }}^{2}+H_{\text {sloc }}^{2}}
$$

where

$H_{\text {sdock }}=$ total significant wave height at the dock

$H_{\text {sdiff }}=$ significant wave height at the dock due to wave diffraction through harbor entrance

Waves also partially reflect from the dock. Interaction between incident and reflected waves effectively increases significant wave height adjacent to the dock by a factor of one plus the reflection coefficient. Assuming waves are symmetric about the swl, one-half of the significant wave height will rise above the swl. Finally, the elevation reached by the crest of the significant wave incident to the dock can be calculated as

$$
W L_{s}=\mathrm{swl}+0.5 * H_{\text {sdock }}\left(1+C_{r}\right)
$$

where

$$
\begin{aligned}
W L_{s} & =\text { elevation reached by crest of significant wave } \\
\mathrm{swl} & =\text { still-water level due to tide and storm effects } \\
C_{r} & =\text { reflection coefficient at dock face }
\end{aligned}
$$

Reflection coefficient values used in this study are 0.5 along the exposed dock face with southwest exposure and 0.1 along the relatively protected dock face with exposure to the south.

These relationships are included in the Fortran program HARBOR so that a time-history of $W L_{s}$ can be easily calculated for each typhoon modeled.

\section{Empirical Simulation Technique}

Storm damage reduction programs and design of coastal structures typically require a storm-surge analysis to obtain a peak water-surface elevation for design water levels. Because typhoons and hurricanes occur infrequently at a given site, abundant storm-surge stages are generally not available and standard ranking 
methods cannot be effectively applied in stage-frequency analysis. Thus, numerical models are often invoked for simulating a larger population of storm-surge events. Traditionally, modeled tropical storms have been synthesized via a joint probability method (JPM) to describe storm attributes, such as maximum wind speeds and pressure deficits. A set of hypothetical storms is built from a combination of parameter values obtained by statistical analysis of historical storms.

The JPM requires that all parameters are statistically independent. However, storm parameters are not statistically independent and the assumption that they are dependent leads to errors when the JPM approach is taken. Because storm parameters are related, random grouping of parameters can cause simulation of storms that may not occur in nature. For example, one parameter may be assigned a value typical of a weak storm, whereas a second parameter may be assigned a value representative of an intense storm. Thus, a level of uncertainty is introduced into the stage-frequency computations. For this study and several other recent CHL studies, an alternative approach, the EST, has been taken. The EST preserves the interdependence of typhoon parameters, which is an advantage over the JPM. Details of the EST are given in Borgman et al. (1992); Scheffner and Borgman (1993); and Scheffner et al. (1999).

\section{Description of technique}

EST is a statistical resampling technique that uses historical data to develop joint probability relationships among the various measured storm parameters. In contrast to the JPM previously discussed, there are no simplifying assumptions concerning development of the probability density functions describing historical events. Thus, the interdependence of parameters is maintained. In this manner, parameter probabilities are site-specific, do not depend on fixed parametric relationships, and do not assume parameter independence. Thus, the EST is distribution-free and nonparametric.

For this study, the EST was developed to generate numerous multiyear intervals of possible future typhoon events for the study site. The ensemble of modeled or simulated events is consistent with statistics and correlations of past storm activity at the site. Furthermore, the EST permits random deviations in storm behavior (when compared to historic events) that could occur in the future. For example, simulated typhoons are permitted to make landfall at locations other than those made by historical storms. These random deviations can also result in more intense storms than the historical events themselves, allowing for the possibility of a future typhoon being the storm of record.

The simulation approach requires specifying a set of parameters that describes the dynamics of some physical system, such as typhoons. These parameters, which must be descriptive of both the physical process being modeled and the effects of that process, are defined as an $\mathrm{N}$-dimensional vector space. The parameters that describe the physical attributes of the process are referred to as input vectors. For example, 


$$
\underline{v}=\left(v_{1}, v_{2}, v_{3}, \ldots, v_{N}\right)
$$

In the case of typhoons, pertinent input vectors include: the central pressure deficit, the radius to maximum winds, minimum distance from the eye of the storm to the location of interest, forward speed of the eye, and the tidal phase during the event. These values can be defined for each specific location and correspond to each particular historical or hypothetical event of the total set of storm events used in the study.

The second class of vectors involve some selected response resulting from the $N$-dimensional parameterized storm, i.e.,

$$
\underline{r}=\left(r_{1}, r_{2}, r_{3}, \ldots, r_{M}\right)
$$

For typhoons, response vectors can include maximum storm surge, shoreline erosion, dune recession, wind-generated wave height and period, bottom erosion, overtopping rate, or any response that can be attributed to the passage of the storm. The maximum total water-surface elevation, resulting from the combined tide and storm surge, is the response vector of interest.

Although response vectors are related to input vectors

$$
v \Rightarrow r
$$

the interrelationship is highly nonlinear and involves correlation relationships which cannot be directly defined, i.e., a nonparametric relationship. For example, in addition to the storm-input parameters, storm surge is a function of local bottom topography, shoreline slope and exposure, ocean currents, etc., as well as their spatial and temporal gradients. It is assumed that these combined properties are implicit in the response vector. For the case of storm surge along the coast of Guam, atmospheric and hydrodynamic models are applied to compute response vectors as a function of the input vectors and local bottom topography together with shoreline configuration. Other response vectors such as sediment transport, shoreline response, and dune recession require application of additional models.

Historical data for storms can be characterized as

$$
\left[v_{i} ; i=1, \ldots, I\right]
$$

where $I$ is the number of historical storm events. For example, let $v_{i}$ have $d_{v}$ components

$$
v_{i}=\mathfrak{R}^{d_{v}}
$$


where $\Re^{d_{v}}$ denotes a $d_{v}$-dimensional space. From this historical data set, a subset of storm events is selected

$$
\left[v_{j}^{*}, j=1, \ldots, J\right]
$$

where $J$ is the number of historical storms contained in the subset. The subset of storms is representative of the entire set of historical storms and is referred to as the training set. Furthermore, those storms comprising the training set are subsequently used as input to numerical models for computing the desired response

vectors. The set of $v_{j}^{*}$ usually includes historical events but may include historical storms with a deviation or perturbation, such as a typhoon with a slightly altered path. Some historical events may also be deleted from the training set if two events are nearly identical such that both would produce the same response. Because the purpose is to fill parameter space $\mathfrak{R}$, two similar events are redundant.

The training set of storms can be augmented with additional storms contained in the historical data set. Storm events augmenting the training set are referred to as the statistical set of storms. Whereas numerical models are used for calculating response vectors for those events in the training set, response vectors for the statistical set of storms are interpolated using the training set response vectors. Thus, stage-frequency relationships can be generated using the entire historical data set without need of simulating all storms in that data set.

With the augmented storm data set (i.e., training and statistical storm sets), the EST produces N simulations of a T-year sequence of events (typhoons), each with their associated input vectors and response vectors. Because there are Nrepetitions of a T-year sequence of events, an error analysis of the results can be performed with respect to median, worst, least, standard deviation, etc. The following describes the procedures by which the input and response data are used to produce multiple simulations of multiple years of events.

\section{Empirical simulation}

Two criteria are required of the T-year sequence of events. The first criterion is that individual events must be similar in behavior to historical events in order that the interrelationships among the input and response vectors remain realistic. For example, a typhoon with high central pressure deficit and low maximum winds is not a reasonable event - the two parameters are not independent although their exact dependency is unknown.

Simulation of realistic events is accounted for in the nearest-neighbor interpolation resampling technique developed by Borgman et al. (1992). A storm event is identified by random sampling from the total storm population. The procedure is equivalent to drawing and replacing random samples from the full storm event population. 
Because simulated events correspond to a specific location, the second criterion to be satisfied is that the total number of storm events selected in the $\mathrm{T}$-years must be statistically representative of the number of historical events that have occurred at the area of study. For this study, 30 typhoon events were identified that passed within $370 \mathrm{~km}$ (200 miles) of Guam and Rota during the 53-year period extending from 1945 through 1997.

Output from the EST program is $N$ repetitions of T-years of simulated storm event responses. It is from these responses that frequency-of-occurrence relationships are computed. The computational procedure followed is based on the generation of a probability distribution function corresponding to each of the T-year sequences of simulated data. Additional detail about the EST is given by Scheffner et al. (1999). 


\section{Implementation of Storm Surge Model}

The process required for application of a long-wave hydrodynamic numerical model at a particular site includes grid generation, model calibration, model validation, and production runs. Accuracy of model results is greatly influenced by the accuracy of boundary and forcing conditions, representation of the geometry of the study area (i.e., bottom topography and land/water interface), and to a lesser degree, the values of certain calibration parameters. Model calibration involves adjustment of the calibration parameters to maximize agreement between model results and measurements.

Upon completion of calibration, the model is subject to a validation that consists of applying the model over a different segment of time from that of the calibration and where no changes have been made to the calibration parameters. The model is considered validated if results agree with measurements within an acceptable degree of error. The validation procedure provides confidence that the model can accurately simulate hydrodynamic processes in the study area.

The strategy for calibrating and validating the storm surge model requires that the model accurately simulate both tidal propagation and storm surge in the study area. The model was first tested for simulation of tidal motion, then tested with the typhoon wind and pressure fields. Procedures applied in conducting model testing and the results of these tests are presented in the following sections.

\section{Calibration of Storm Surge Model}

The model was calibrated for tidal propagation and subsequently verified for storms. Water-level measurements were available from one gauge within the study area located in Apra Harbor at the entrance to Sumay Cove. The gauge is operated by the U.S. National Ocean Service (NOS). The gauge location is $13.4435 \mathrm{~N}, 144.6566 \mathrm{E}$. Tide gauge data for the month of January 1997 illustrate tidal behavior at Apra Harbor (Figure 10). Mean tide range is only $0.5 \mathrm{~m}(1.7 \mathrm{ft}$ ). The tide is characterized by a large diurnal inequality. High tides are generally relatively close to msl and lower low tides typically drop well below msl. The probability distribution of hourly tide levels during the year 1991, a relatively 


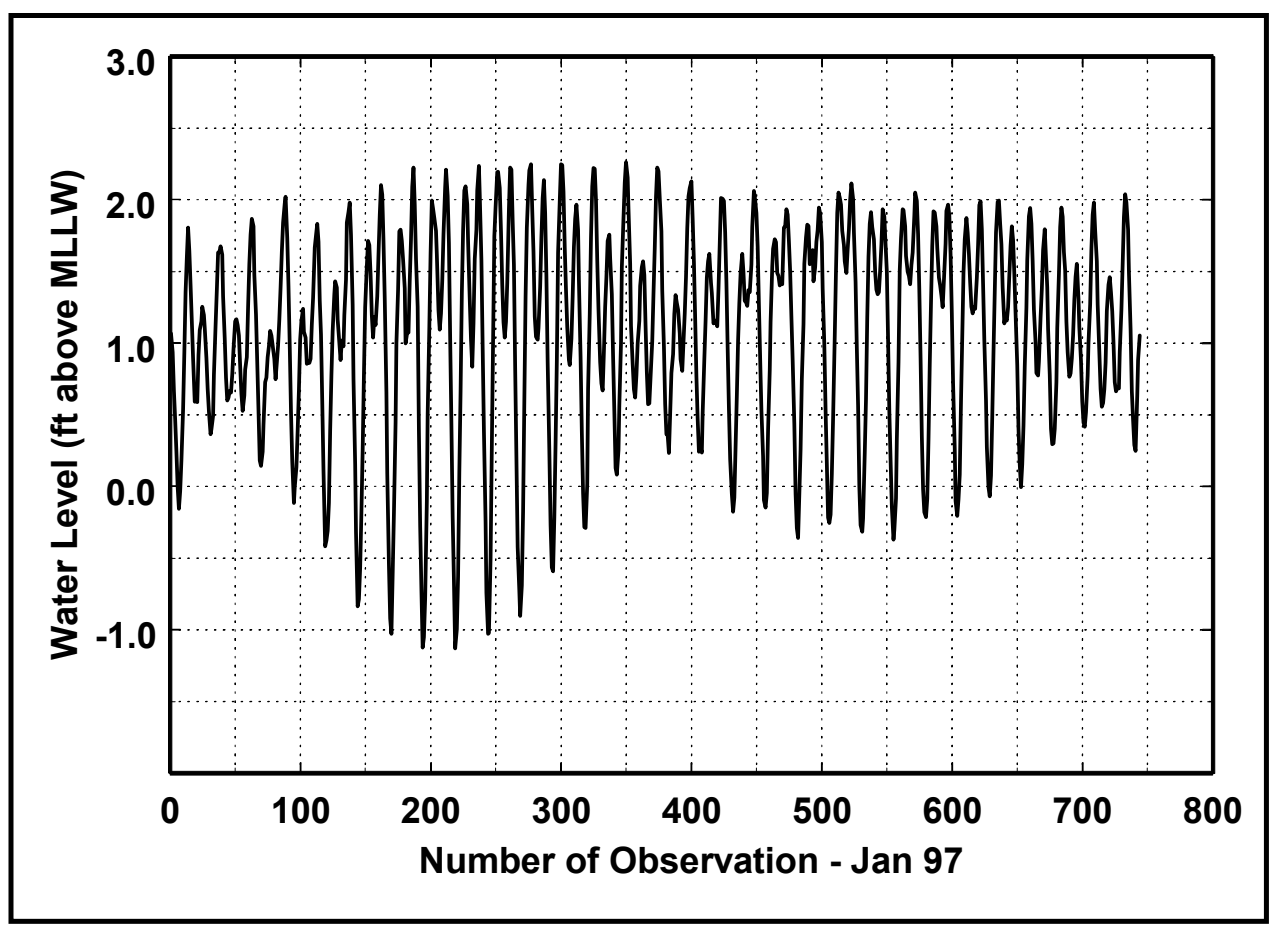

Figure 10. Tide gauge data, Apra Harbor, January 1997 (To convert feet to meters, multiply by 0.3048 )

complete data year, also illustrates that high tides are generally near msl while low tides can deviate significantly from msl (Figure 11).

Because measurements are available at only one location, the model could not be tested for accuracy at other locations in the study area. However, because the inner regions of bays and harbors are relatively difficult to calibrate in comparison to deeper coastal and open ocean regions, it is expected that accurate calculated water levels in the harbor assure accurate water-level calculations in other regions of the model domain.

Calibration of the storm-surge model was conducted by driving the model with six tidal constituents and comparing the results to gauge data. Table 6 gives the tidal constituents at Apra Harbor as determined by NOS. The model was run for a time period of eight days at the beginning of January 1997. The simulated water level time series at the gauge location compares favorably to measurements, which have been adjusted to msl during the simulated time period to provide a consistent basis for comparison (Figure 12). This calibration was considered sufficient for purposes of the present study.

\section{Validation of Storm Surge Model}

The storm surge model was validated by comparison of measured and calculated time-series water levels at Apra Harbor gauge for the period when Typhoon 


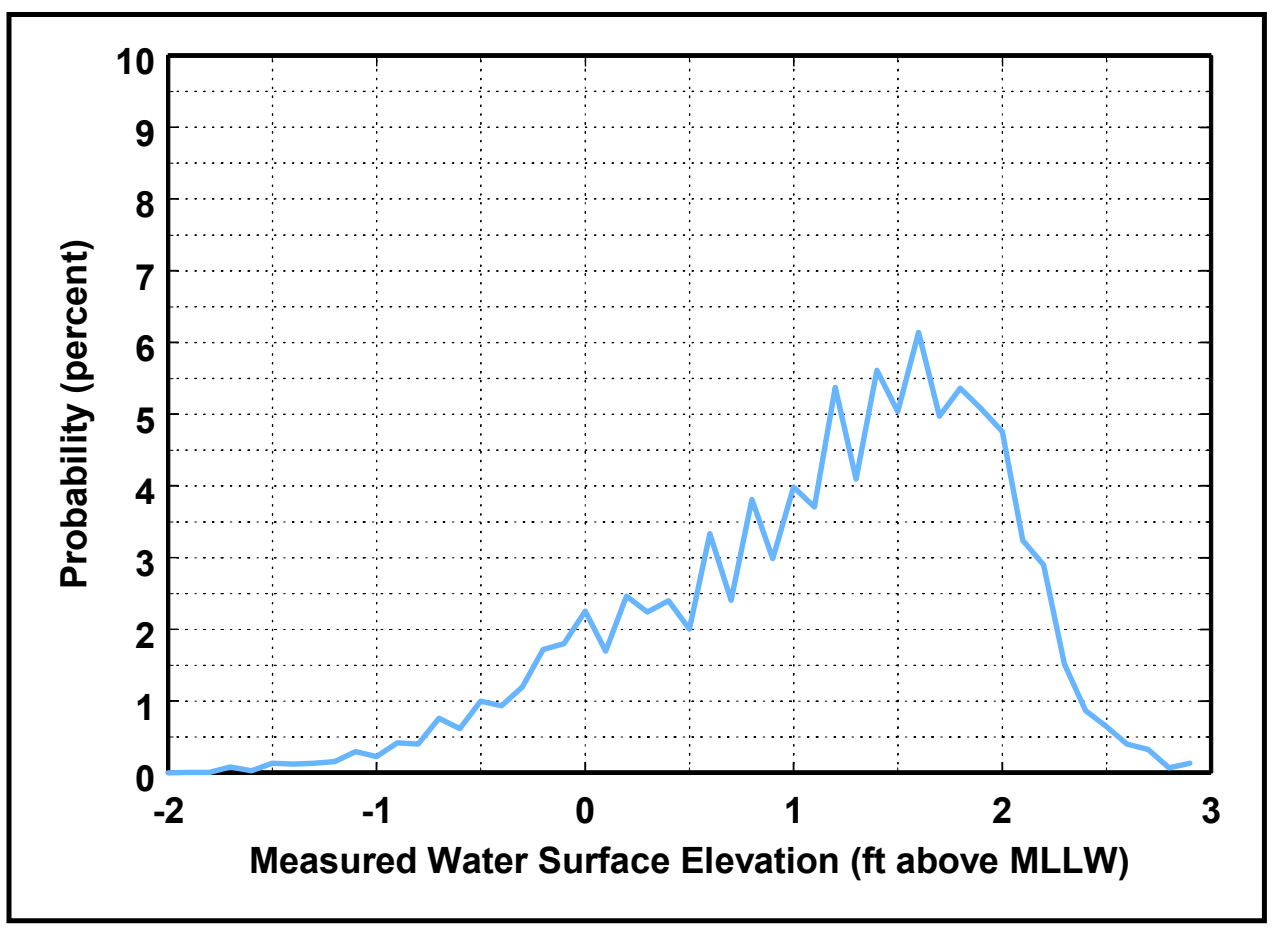

Figure 11. Probability distribution of tide gauge data, Apra Harbor, Jan-Dec 91 (To convert feet to meters, multiply by 0.3048 )

\begin{tabular}{|c|c|c|c|c|c|}
\hline Constituent & $\begin{array}{l}\text { Amplitude } \\
\text { cm (in.) }\end{array}$ & $\begin{array}{l}\text { Phase } \\
\text { deg }\end{array}$ & Constituent & $\begin{array}{l}\text { Amplitude } \\
\text { cm (in.) }\end{array}$ & $\begin{array}{l}\begin{array}{l}\text { Phase } \\
\text { deg }\end{array} \\
\end{array}$ \\
\hline $\mathrm{M}_{2}$ & $21.6(8.5)$ & 221.0 & $\mathrm{~K}_{1}$ & $16.9(6.7)$ & 215.2 \\
\hline $\mathrm{S}_{2}$ & $5.8(2.3)$ & 249.3 & $\mathrm{O}_{1}$ & $11.4(4.5)$ & 181.6 \\
\hline $\mathrm{N}_{2}$ & $4.7(1.9)$ & 198.1 & $P_{1}$ & $5.0(2.0)$ & 207.7 \\
\hline
\end{tabular}

Omar passed through the study area (Figure 13). The calculated water level contains storm effects only and not tides. However, the model clearly produced a realistic simulation of the storm surge due to Typhoon Omar. 


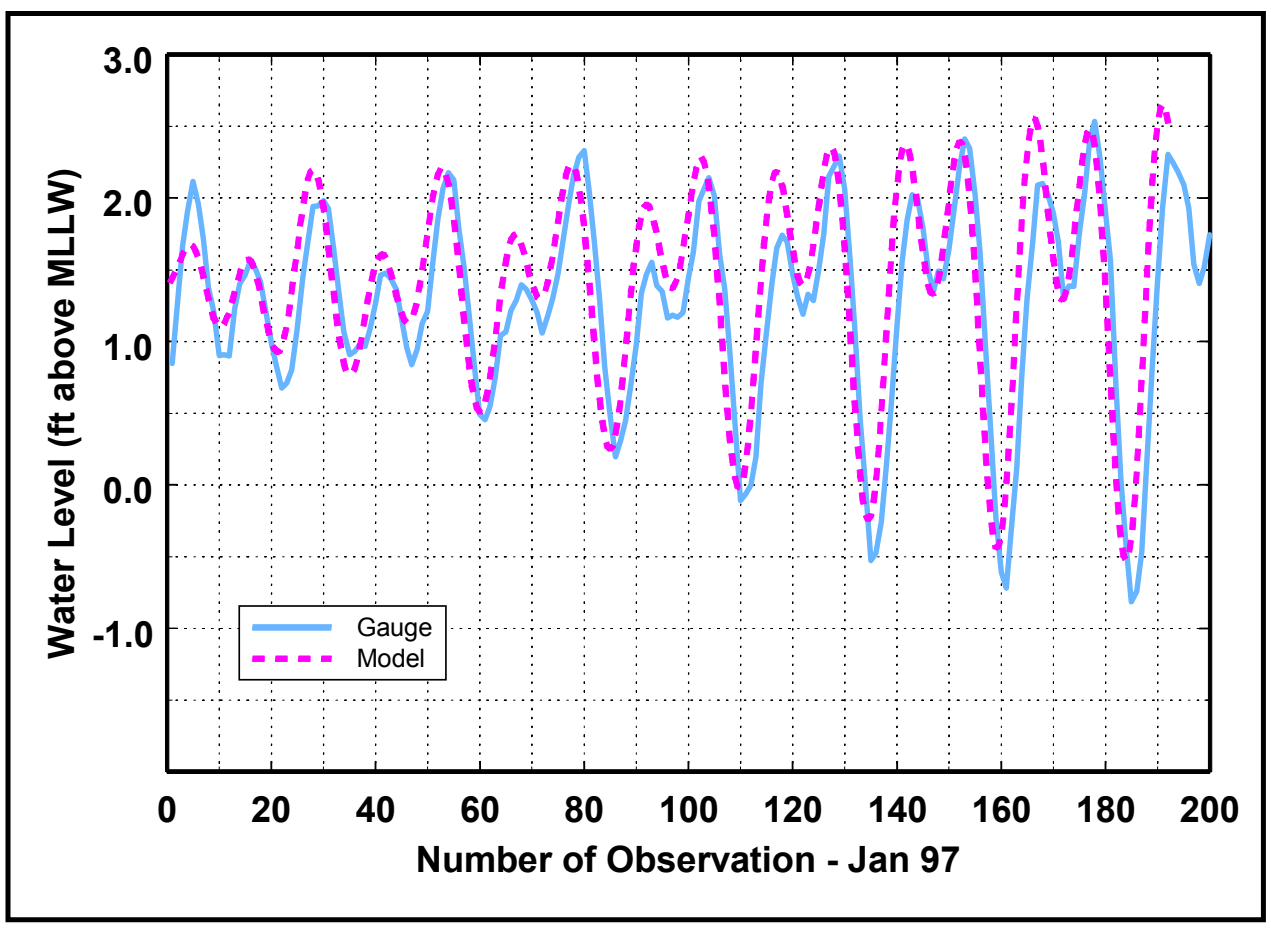

Figure 12. Measured and modeled water level at the Apra Harbor gauge for 1-8 Jan 97 (To convert feet to meters, multiply by 0.3048 )

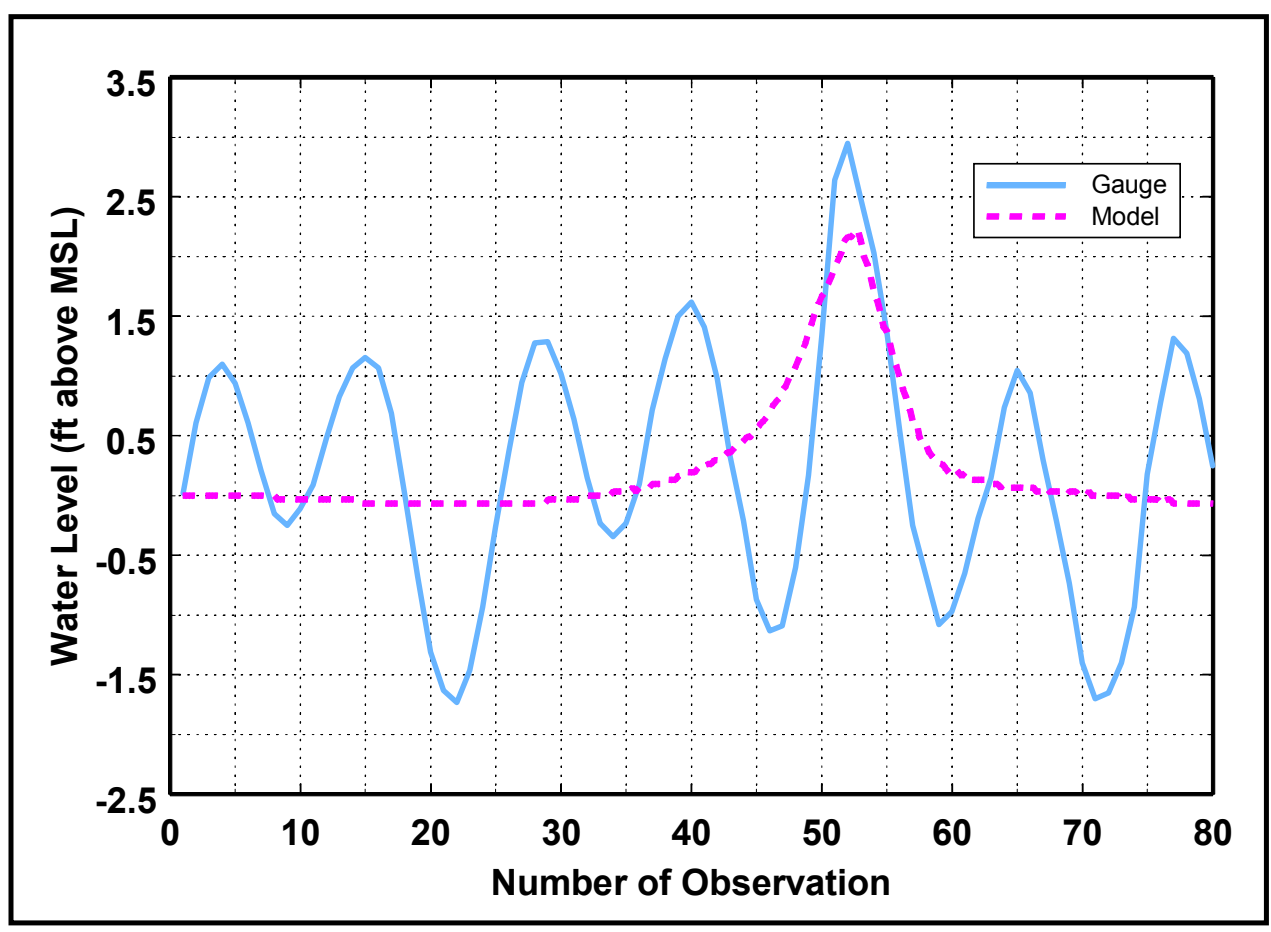

Figure 13. Measured and modeled water level in Apra Harbor for Typhoon Omar, during 0600 UTC 26 Aug through 130029 Aug 92 (To convert feet to meters, multiply by 0.3048 ) 


\section{Development of Overtopping and Stage- Frequency Relationships}

Overtopping-frequency relationships were developed for the project area along the north side of Cabras Island, Guam, in four tasks. First, the training set of storms was developed from a storm database for the western Pacific Ocean, and the PBL model was applied to calculate wind fields associated with each storm in the training set. Second, the storm-surge model was applied with wind and atmospheric pressure forcing from the PBL model as time-dependent input. Time-series of storm-surge elevations associated with each storm were calculated for specified stations. Third, time series of wave parameters were calculated by application of the wave and wave-transformation models. Time series of ponding level, setup, runup, and overtopping were calculated for each profile location in the study site. Fourth, the EST was applied to compute overtoppingfrequency relationships based on the typhoon event parameters and calculated overtopping rates.

The harbor side analysis included two additional tasks. First, wind, offshore wave, and storm surge information from ocean modeling tasks was used to develop storm water level elevations at the commercial dock along the south side of Cabras Island. Second, the EST was applied to compute stage-frequency relationships based on typhoon parameters and calculated water levels due to storm surge and waves.

This chapter briefly reviews procedures implemented for developing overtopping and stage-frequency relationships for the study area and presents study results. Previous chapters give more detailed background on some aspects of the study. The set of historical storms included in the training set is given in and discussed in Chapter 2 (Table 1). Storm tracks are provided in Appendix A. Detailed discussion of the modeling approach is given in Chapter 3.

\section{Storm Surge/Tidal Elevation Relationship}

Storm-surge elevations are dependent on water depth as well as intensity and angle of approach of the storm. The most accurate method for calculation of 
surge is inclusion of tides in the storm-surge simulation. However, this approach is not practical for stage-frequency analysis because numerous tidal phases would have to be modeled for each storm in the training set to acquire a representative set of surge and tide combinations. An alternative approach was taken in this study to estimate the combined water-surface elevation of the surge and tide. Simulations were performed for each of the 30 storms in the training set, where the swl was taken to be msl. Tides were not included in the computations. Because storm surges are small for the study site, the water-surface elevation for the combined surge and tide can be approximated as a linear superposition of the two. Thus, swl for stage-frequency computations was calculated by addition of the surge to a specific tidal elevation.

A total of 13 numerical gauge stations was specified as locations for surge output from the storm-surge model. The stations for both ocean and harbor sides of Cabras Island are shown in Figure 14. The only numerical gauge station not shown was as the NOS tide gauge location. Appendix B gives the latitude and longitude of stations. Water-level values were stored at 15-min intervals at each station. Combined time-series water-level and wave information were applied for ponding level, setup, runup, and overtopping calculations.

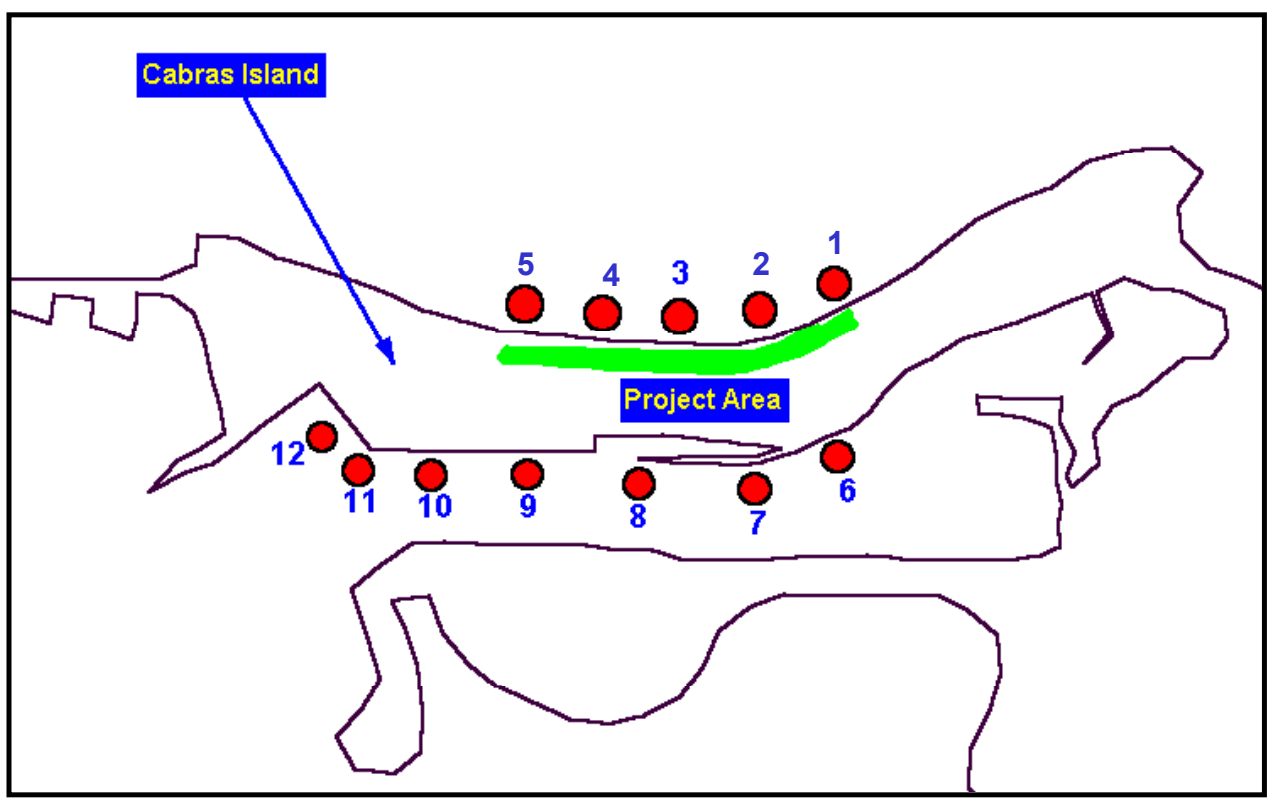

Figure 14. Storm surge station locations for Cabras Island

\section{Spectral Wave Transformation}

Waves in the open ocean calculated by the WISWAVE model were transformed to near-breaking by application of WAVTRAN, described in Chapter 3 . Estimates were made of the general nearshore depth contour and shoreline orientation closest to each of the numerical gauge locations specified in Appendix B. In addition, estimates of sheltering angle bands were made based on shoreline geometry. For all of the numerical gauge locations, one-sided sheltering was applied. 
Initially, waves were transformed to a water depth of $10 \mathrm{~m}(33 \mathrm{ft})$. If maximum significant wave height during the typhoon exceeded $4 \mathrm{~m}(13 \mathrm{ft})(0.4$ times the water depth), WAVTRAN was rerun to transform to a deeper nearshore depth. Nearshore depth was increased in 5-m (16-ft) increments until maximum significant wave height during the storm was less than 0.4 times the depth or until the nearshore depth reached $30 \mathrm{~m}(98 \mathrm{ft})$. This transformation approach is expected to produce realistic incident significant wave heights for calculation of nearshore processes.

\section{Water Level Over Reef}

Wave setup on reefs occurs due to overtopping of waves onto the reef platform. As waves break on the reef, water is deposited causing an elevated water level, which is typically referred to as ponding over the reef. Seelig (1983) conducted a set of laboratory experiments for fringing reefs typical of Guam to investigate hydraulics of reef-lagoon systems. Seelig's formulations were applied in this study. Parameter ranges in Seelig's study were: still-water depth at the reef crest was $0 \mathrm{~m}(0 \mathrm{ft})$ and $2 \mathrm{~m}(6.6 \mathrm{ft})$; wave periods ranged from 8 to $16 \mathrm{sec}$; and irregular deepwater significant wave height ranged from 2.5 to $10.7 \mathrm{~m}(8.2$ to $35.1 \mathrm{ft}$ ). These conditions are representative of the typhoon events impacting Cabras Island.

Seelig (1983) found that the ponding water level is a function of the swl (astronomical tide and storm surge), incident deepwater significant wave height, and wave period. Gourlay (1996) confirmed these findings. Contributions to the ponding level include waves breaking on the reef, but do not include setup from reformed waves at the shoreward end of the reef. Ponding level can be estimated by (Seelig 1983)

$$
\eta=a_{1}+a_{2} \log \left(H_{0}^{2} T\right)
$$

where $\eta$ is the ponding level in $\mathrm{m}, H_{0}$ is the deepwater significant wave height in $\mathrm{m}, T$ is the wave period in sec, and $a_{1}$ and $a_{2}$ are empirical coefficients dependent on the swl and wave spectrum (monochromatic or irregular). Table 7 gives values of the empirical coefficients for irregular waves.

\begin{tabular}{||l|l|l||}
\hline \multicolumn{2}{||l||}{$\begin{array}{l}\text { Table } 7 \\
\text { Ponding Level Coefficients for Irregular Waves (Seelig 1983) }\end{array}$} \\
\hline \hline Depth, $\mathbf{m}(\mathrm{ft})$ & $\mathrm{a}_{1}$ & $\mathbf{a}_{\mathbf{2}}$ \\
\hline \hline $0(0)$ & -0.92 & 0.77 \\
\hline $2(6.6)$ & -1.25 & 0.73 \\
\hline \hline Note: Depth measured relative to reef crest; coefficients are based on SI units. \\
\hline
\end{tabular}


In this study, elevation of the reef crest was taken as $0.3 \mathrm{~m}(1 \mathrm{ft})$ below mllw. Depth over the reef crest is calculated based on a water level due to the sum of astronomical tide and storm surge. When depth over the reef is less than $2 \mathrm{~m}(6.6 \mathrm{ft})$, which is typically the case, ponding is calculated for both cases in the table and an interpolated ponding value is used.

Astronomical tide was included as a single level in this study for three reasons. First, the tide range is relatively small. Second, tide levels at this location are characteristically in a very narrow range between msl and mean high water (mhw) most of the time, as discussed in Chapter 4. Finally, extreme overtopping rates are not directly related to tide level, as with stage-frequency analysis, so the customary introduction of varying tide levels in EST analysis is no longer possible. The tide level used in this study was mhw, a representative, but not extreme, high tide level.

\section{Wave Setup, Runup, and Overtopping}

Although high waves break on the reef, a significant amount of wave energy can remain and continue to propagate across the reef to shore. The height of these waves is limited by shallow water depths over the reef. Previous investigations have indicated that significant wave height across a relatively flat reef is limited to approximately 0.4 times the local water depth (e.g., Smith 1993). That limit was applied in this study, with water depth over the reef including tide, storm surge, and ponding. During an intense nearby typhoon, depth over the reef can exceed $3.04 \mathrm{~m}(10 \mathrm{ft})$, giving nearshore significant wave heights of over $1.21 \mathrm{~m}(4 \mathrm{ft})$.

Waves which have propagated across the reef lagoon encounter the nearshore slope approaching the seawall. Again, they break and cause a local increase in water level. This contribution to water level, referred to as wave setup, is not included in the ponding calculation. It is calculated as (Shore Protection Manual 1984)

$$
S_{w}=0.15 d_{b}-\frac{\sqrt{g}\left(H_{o}^{\prime}\right)^{2} T}{64 \pi d_{b}^{1.5}}
$$

where

$$
\begin{aligned}
S_{w} & =\text { nearshore wave setup } \\
d_{b} & =\text { water depth at breaking } \\
H_{o}^{\prime} & =\text { equivalent normally incident deepwater significant wave height }
\end{aligned}
$$

Water depth over the reef and significant wave height over the reef were used for parameters $d_{b}$ and $H_{o}^{\prime}$, respectively. 
Breaking waves at the shore intermittently push water up the beach, creating wave runup. For both existing and plan nearshore profiles in the project area, runup during an intense typhoon can reach the seawall crest and continue over the top of the seawall. This wave overtopping can create problems along the commercial port road due to flooding, debris, and damage to the road surface. It can also cause flooding in the Apra Harbor container yard. Wave overtopping rate was calculated with the methodology described in Chapter 3, developed by van der Meer and Janssen (1994). Reduction factors used in the calculation were determined to fit this application and produce overtopping rates consistent with qualitative observations of storm damage in the project area, as discussed in the following section.

Wave setup and overtopping rates were computed along 15 transects within the study area. Transects were specified by elevation profiles surveyed and provided by the Honolulu District. Plan profiles were also provided. Elevations were specified relative to mllw. The project stations modeled are at $61-\mathrm{m}$ (200-ft) intervals, beginning with Sta $00+00$ and ending with Sta $28+00$.

\section{Implementation of Overtopping Method}

The methodology used to estimate overtopping rates along the north shore of Cabras Island includes four reduction factors to represent a variety of physical factors which can reduce overtopping. Implementation of these reduction factors requires a calibration/validation process to ensure that the methodology is giving a reasonable representation of the project area. This section describes the implementation for Cabras Island, Guam.

Three historical typhoons which caused damage to the commercial port road in the study area are considered in the feasibility report (USAED, Pacific Ocean, 1995). Typhoon Roy (0188) and Typhoon Koryn (0190) were reported to cause significant overtopping of the seawall and washing of rubble and debris onto the road. Typhoon Omar (1592) caused similar damage but to a lesser extent due to rapidly changing conditions as the eye passed almost directly over the study area.

The same three storms were used in this study to help calibrate overtopping rate calculations to be consistent with documented experience. Since no quantitative overtopping information is available, published information about dangerous overtopping rates on roadways was used to assess calculated overtopping rates. Ward and Ahrens (1992) report on a study by Fukuda, Uno, and Irie (1974) which determined that an overtopping rate greater than about $0.00002 \mathrm{~m}^{3} / \mathrm{sec} / \mathrm{m}(0.0002 \mathrm{cfs} / \mathrm{ft})$ would prohibit a vehicle from driving past at high speed a distance of $3 \mathrm{~m}(10 \mathrm{ft})$ behind the coastal structure. At a distance of $9 \mathrm{~m}$ (30 ft) behind the structure, the threshold overtopping rate is $0.0002 \mathrm{~m}^{3} / \mathrm{sec} / \mathrm{m}(0.002 \mathrm{cfs} / \mathrm{ft})$. CIRIA/CUR (1991) give threshold overtopping rates of about $0.000001 \mathrm{~m}^{3} \mathrm{sec} / \mathrm{m}(0.00001 \mathrm{cfs} / \mathrm{ft})$ for the onset of unsafe high speed traffic and minor structural damage to buildings and around $0.00003 \mathrm{~m}^{3} / \mathrm{sec} / \mathrm{m}(0.0003 \mathrm{cfs} / \mathrm{ft})$ for the onset of unsafe driving at any speed and significant structural damage. 
An overtopping rate time series was computed for each of the three calibration storms acting on the existing profiles. The berm reduction factor was determined as recommended by VJ. Since most existing profiles do not have a berm, this factor affected only a small number of profiles. The reduction factor for influence of a shallow foreshore was initially set equal to one. The reef presence suggests that a value less than one could be more appropriate, but behavior of waves over a reef during intense typhoon winds is not well documented. The reduction factor for influence of roughness was initially set equal to one. The presence of rubble on the shore suggests that a value less than one may be applicable, but the overall roughness impact of the rubble is unknown. The reduction factor for influence of angle of wave attack was set equal to one. This value is appropriate since the long-period waves characteristic of intense typhoons can be expected to approach nearly perpendicular to shore.

The range of maximum overtopping rates calculated for the 15 existing profiles during each of the three storms is given in Table 8. Overtopping rates for Roy and Omar are significantly greater than the damage threshold overtopping levels. For Koryn, overtopping rates are on the order of damage threshold levels and substantially lower than for the other two storms. Since USAED, Pacific Ocean (1995) reported similar impacts and similar tide levels for both Roy and Koryn, the difference between calculated results for the two storms is larger than would be expected. One factor which could impact calculations for Koryn is that typhoon track data is specified with 0.1-deg and 6-hr accuracy. Koryn passed on the east side of Guam, moving almost directly north. A small error or imprecision in the east-west placement of the track could have a significant impact on processes in the project area.

\begin{tabular}{||l|l||}
\hline \hline $\begin{array}{l}\text { Table } 8 \\
\text { Maximum Calculated Overtopping Rates for Calibration Storms }\end{array}$ \\
\hline \hline Typhoon & $\begin{array}{l}\text { Range of Maximum Overtopping Rate } \\
\mathbf{m}^{3} / \mathbf{s e c} / \mathrm{m} \text { (cfs per ft) }\end{array}$ \\
\hline Roy (BWP0188) & 0.00098 to 0.00519 (0.0105 to 0.0559$)$ \\
\hline Koryn (BWP0190) & 0.00001 to 0.00007 (0.0001 to 0.0008$)$ \\
\hline Omar (BWP1592) & 0.00135 to 0.01297 (0.0145 to 0.1396$)$ \\
\hline
\end{tabular}

Since Koryn caused documented damage along the commercial port road and calculated overtopping rates are around the threshold rates for damage, it was decided to set the reduction factors for influence of shallow foreshore and roughness to one for all applications with existing profiles.

For plan profiles, the reduction factor for influence of shallow foreshore was set equal to one, as with existing profiles. However, the reduction factor for influence of roughness will be affected by the planned addition of CORE-LOC ${ }^{\mathrm{TM}}$ units to the nearshore profile. A roughness factor of 0.6 was taken for the CoreLoc portion of the profile. The section of nearshore profile one significant wave height above and below the swl was used to determine the reduction factor for influence of roughness. Using a linear weighting, factors of 0.6 for Core-Loc slope and 1.0 for other parts of the profile were combined to give the overall 
reduction factor, which varied with swl and significant wave height during the course of each typhoon.

\section{Overtopping-Frequency Relationships}

Overtopping-frequency relationships were calculated for 15 profiles along the project area on the north shore of Cabras Island by application of the EST. These relationships were computed for maximum conditions at intervals of 5, 10, 25,50 , and 100 years. Input for the EST included maximum overtopping rate calculated for each of the 30 storms in the training set. The maximum overtopping rate was calculated as described previously, using 100 independent simulations of a 100-year time period. Maximum overtopping rates with 100 -year return period illustrate variability along the coast (Figure 15). These values represent mean results from the 100 simulations. Most profiles have overtopping rates of about $0.07 \mathrm{~m}^{3} / \mathrm{sec} / \mathrm{m}(0.7 \mathrm{cfs} / \mathrm{ft})$ for existing conditions and $0.01 \mathrm{~m}^{3} / \mathrm{sec} / \mathrm{m}(0.1 \mathrm{cfs} / \mathrm{ft})$ for plan profiles. Existing profiles 6 and 28 have reduced overtopping rates which are more like the plan overtopping rates, a consequence of the natural berm present on these existing profiles. Tables of overtopping-frequency relationship values for each profile are given in Appendix C. Maximum expected overtopping rate values and standard deviations are given in the tables for both existing and plan profiles.

Maximum overtopping rates for the full project length can be obtained from the profile results. Profile overtopping rates are given as cfs per ft width. Since profiles are at 61-m (200-ft) intervals, each profile overtopping rate can be multiplied by 61 (200) to give total overtopping rate along the section of coast represented by the profile. The first and last profiles are considered to represent an $82-\mathrm{m}(270-\mathrm{ft})$ width so that the full project length is included. Total overtopping rates along the project area are summarized in Table 9 and Figure 16. The planned project has a strong impact on reducing overtopping rates.

\section{Harbor Side Stage-Frequency Relationships}

Stage-frequency relationships were calculated for seven storm surge stations along the south side of Cabras Island by application of the EST. The relationships were computed for maximum water level at return intervals of 5, 10, 25, 50, 75 and 100 years. Input for the EST included maximum water level calculated for each of the 30 storms in the training set. Maximum water level was calculated as the linear superposition of storm surge, tide, and significant wave effects, as discussed in Chapter 3. Tide levels of mean high water, mean sea level, and mean low water were used in developing EST probabilities. Tables of stage-frequency relationship values for each station are given in Appendix E.

In addition to the stage-frequency tables, values of wave parameters and water level components for each storm at each station are given in Appendix F. These tables show the relative importance of wave and surge components in 


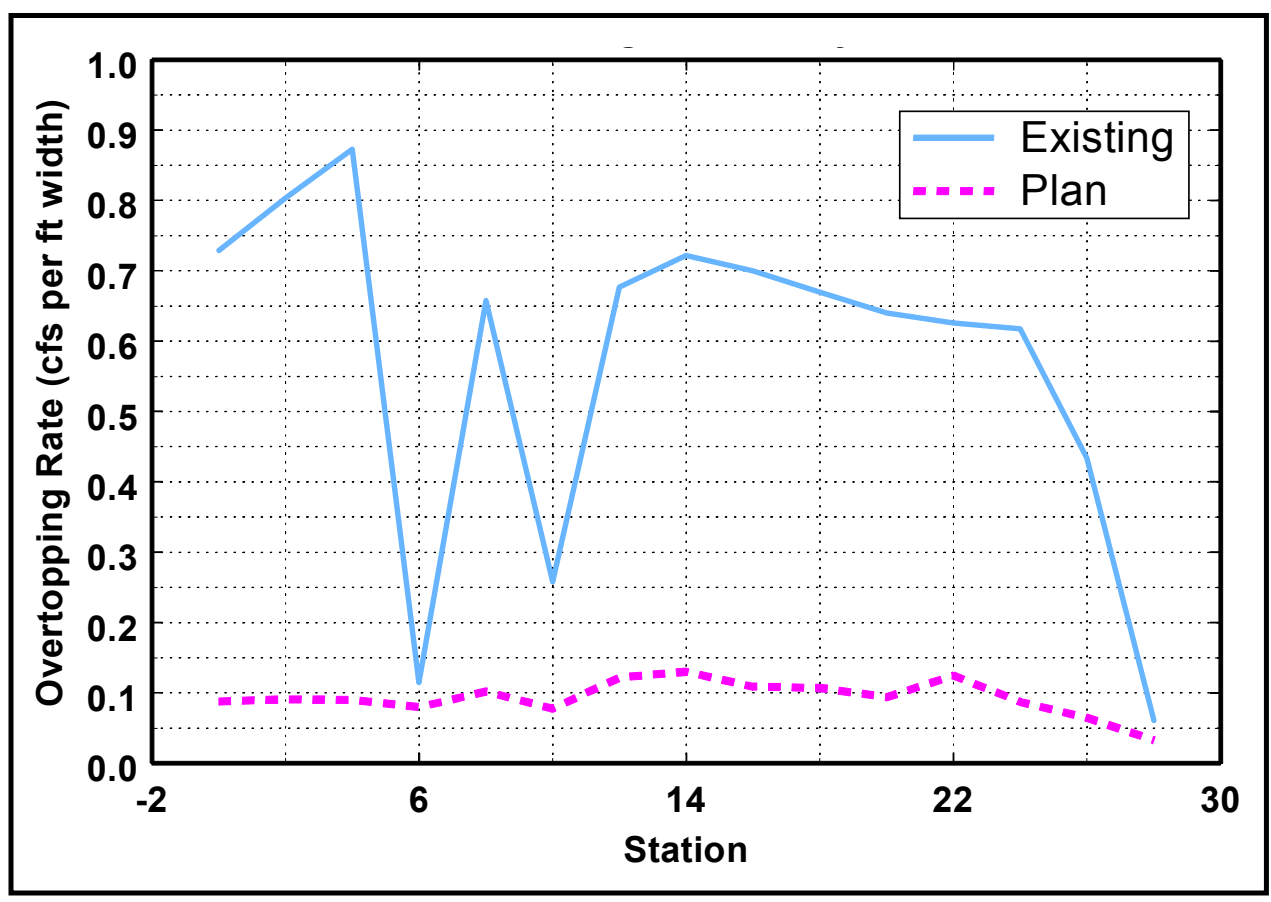

Figure 15. Station overtopping rates, 100 -year return period (To convert cubic feet per second to cubic meters per second, multiply by 0.02831685 ) (To convert feet to meters, multiply by 0.3048 )

\begin{tabular}{||l|l|l|}
\hline \multirow{2}{*}{$\begin{array}{l}\text { Table 9 } \\
\text { Maximum Overtopping Rates along Project Length }\end{array}$} \\
\hline \hline \multirow{2}{*}{ Return Period, year } & \multicolumn{2}{|c|}{ Maximum Overtopping Rate, $\mathbf{m}^{3}$ per sec (cfs) } \\
\cline { 2 - 3 } & Existing & Plan \\
\hline 2 & $0.0(0.0)$ & $0.0(0.0)$ \\
\hline 5 & $1.03(36.4)$ & $0.0(0.0)$ \\
\hline 10 & $8.15(287.7)$ & $0.86(30.5)$ \\
\hline 25 & $25.19(889.4)$ & $3.11(110.0)$ \\
\hline 50 & $36.68(1295.4)$ & $5.17(182.4)$ \\
\hline 75 & $45.65(1612.1)$ & $7.15(252.6)$ \\
\hline 100 & $50.19(1772.3)$ & $8.18(288.7)$ \\
\hline
\end{tabular}

determining water level along the south side of Cabras Island. For the high total water level cases, waves are the dominant factor.

In addition to overtopping-frequency information, values of wave parameters, storm surge, ponding level, setup and overtopping rate corresponding to the peak overtopping event for each storm are presented in Appendix D for each profile. Wave parameters include significant height, peak period, and approach direction. 


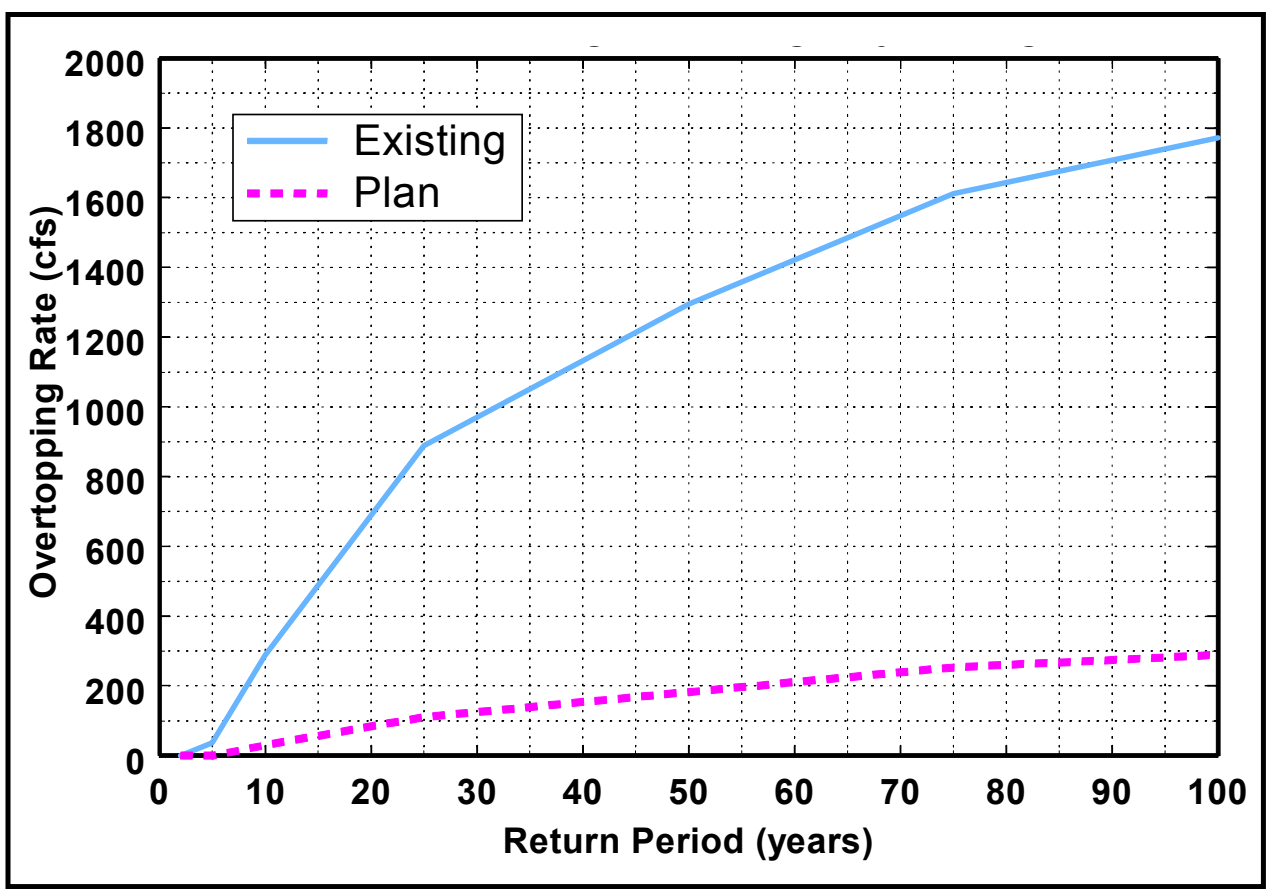

Figure 16. Total overtopping rate along project length (To convert cubic feet per second to cubic meters per second, multiply by 0.02831685 )

Two additional key points affect interpretation of the harbor side total water levels and stage-frequency relationships. First, the total water level is reached only by the crest of a wave with height equal to the significant wave height or by the portion of crest above that level for waves higher than the significant wave height. Thus, the total water level would be reached or exceeded for short time intervals (several seconds) interspersed with longer time periods of lower water level. Second, the wave contribution is strongly dependent on reflection coefficient at the shore, which is not well-documented. This dependence is especially important at the two most exposed stations (Stations 11 and 12), where a reflection coefficient of 0.5 was used. Reflection coefficient at the more sheltered stations, with highly oblique exposure to the open harbor (Stations 6 through $10)$, was reduced to 0.1 . 


\section{Summary and Conclusions}

A set of typhoon-induced overtopping-frequency relationships was developed for a proposed project area along the north shore of Cabras Island, Apra Harbor, Territory of Guam. Both existing and plan nearshore profiles were considered. The objective was to assist the Honolulu District in evaluating vulnerability of the commercial port road, container yard, and other port facilities to wave overtopping of the existing seawall, which will remain in the proposed project. Calculation of surge, wind and pressure field, and wave characteristics were performed for 30 historical storms through application of numerical models. Wave-induced setup, runup, and overtopping rates were calculated at 15 profile locations specified by the Honolulu District nearshore surveys in the project area.

A similar analysis was conducted for the south shore of Cabras Island, along existing and potential commercial dock areas, to evaluate exposure to storm events on the harbor side. Stage-frequency relationships were developed.

The circulation model ADCIRC was applied for calculation of storm surge in the study area. Model calculations compared well to NOS tide and storm surge data for Apra Harbor. For storm surge calculation, ADCIRC applied wind and pressure fields calculated by the PBL model as the atmospheric forcing.

The PBL model was applied for simulation of storms whose path brought the storm center within a 370-km (200-mile) radius of Guam and Rota. Historical data from the storms were input into the PBL model for calculation of wind and pressure fields. Atmospheric fields calculated by the PBL model were applied as forcing for the circulation and wave models.

Deepwater wave heights, periods, and directions for each storm were calculated by application of the wave model WISWAVE. These deepwater waves were transformed along the north shore of Cabras Island by application of the wave-transformation model WAVTRAN.

Storm surge (wind- and atmospheric pressure-induced) was simulated for 30 historical storms and referenced to mean sea level. Guam is a volcanic cone with steep sides. Shallow shelf areas do not exist around the island, so the storm surge does not build appreciably near shore, as on the east coast of the United States. Consequently, the storm surge (without consideration of waves) is generally small and contributes only a small amount to coastal inundation during 
severe storms. Wave effects, including ponding on the reefs, setup, runup, and overtopping, are the major cause of high inundation levels during storm events.

Along the north shore of Cabras Island, the EST was applied to calculate overtopping-frequency relationships based on historical storm parameters and calculated response to the storms. These relationships were calculated from the maximum overtopping rates computed for each storm. Overtopping-frequency values and their standard deviations were calculated for $2,5,10,25,50,75$, and 100 -year return periods at 15 profiles. The proposed project has a major impact on reducing overtopping rates.

Similarly, the EST was applied along the south shore of Cabras Island to calculate stage-frequency relationships for six return periods, up to the 100-year event. The relationships are based on maximum water levels for each storm due to storm surge, tide, and wave effects. 


\section{References}

Atkinson, G. D., and Holliday, C. R. (1977). "Tropical cyclone minimum sea level pressure/maximum sustained wind relationship for the western North Pacific," Monthly Weather Review 105, 421-427.

Borgman, L., Miller, M., Butler, L., and Reinhard, R., (1992). "Empirical simulation of future hurricane storm histories as a tool in engineering and economic analysis," Fifth International Conference on Civil Engineering in the Oceans, ASCE, College Station, TX, 2-5 November 1992.

Bouws, E., Gunther, H., Rosenthal, W., and Vincent, C. L. (1985). "Similarity of the wind wave spectrum in finite depth water 1 spectral form," Journal of Geophysical Research 1(C1), 975-986.

Cardone, V. J., Greenwood, C. V., and Greenwood, J. A. (1992). "Unified program for the specification of hurricane boundary layer winds over surfaces of specified roughness," Contract Report CERC-92-1, U.S. Army Engineer Waterways Experiment Station, Vicksburg, MS.

CIRIA/CUR. (1991). Manual on the use of rock in coastal and shoreline engineering. CIRIA Special Publication 83, Construction Industry Research and Information Association, London, UK; and CUR Report 154, Centre for Civil Engineering Research and Codes, Gouda, The Netherlands.

De Waal, J. P., and van der Meer, J. W. (1992). "Wave runup and overtopping at coastal structures," Proceedings, $23^{\text {rd }}$ International Conference on Coastal Engineering, ASCE, Venice, Italy.

Flather, R. A. (1988). "A numerical model investigation of tides and diurnalperiod continental shelf waves along Vancouver Island," Journal of Physical Oceanography 18, 115-139.

Fukuda, N., Uno, T., and Irie, I. (1974). "Field observations of wave overtopping of wave absorbing revetment," Coastal Engineering in Japan, Vol. 17.

Gourlay, M. R. (1996). "Wave set-up on coral reefs. 2. Set-up on reefs with various profiles," Coastal Engineering 28, 17-55. 
Gravens, M. B., Kraus, N. C., and Hanson, H. (1991). "GENESIS: Generalized Model for Simulating Shoreline Change. Report 2, Workbook and System User's Manual," Technical Report CERC-89-18, U.S. Army Engineer Waterways Experiment Station, Vicksburg, MS.

Headquarters, U.S. Army Corps of Engineers. (1989). "Water levels and wave heights for coastal engineering design," Engineer Manual 1110-2-1414, Washington, DC. . (2001). Coastal Engineering Manual, EM 1110-2-1100, Washington, DC.

Hubertz, J. M. (1992). “User's guide to the Wave Information Studies (WIS) wave model, Version 2.0," WIS Report 27, U.S. Army Engineer Waterways Experiment Station, Vicksburg, MS.

Jelesnianski, C. P., and Taylor, A. D. (1973). "A preliminary view of storm surges before and after storm modifications," NOAA Technical Memorandum ERL WMPO-3, Weather Modification Program Office, Boulder, CO.

Jensen, R. E. (1983). "Methodology for the calculation of a shallow-water wave climate," WIS Report 8, U.S. Army Engineer Waterways Experiment Station, Vicksburg, MS.

JTWC. (1991). “Tropical cyclones affecting Guam, 1671-1990," NOCC/JTWC Tech Note 91-2, U.S. Naval Oceanography Command Center, Joint Typhoon Warning Center, Guam.

Kolar, R. L., Gray, W. G., Westerink, J. J., and Luettich, R. A. (1993). "Shallow water modeling in spherical coordinates: Equation formulation, numerical implementation, and application," Journal of Hydraulic Research 32(1), 3-24.

Mark, D. J. (1996). "Southern Guam typhoon stage-frequency analysis," Miscellaneous Paper CERC-96-7, U.S. Army Engineer Waterways Experiment Station, Vicksburg, MS.

Mark, D. J., and Scheffner, N. W. (1997). "Coast of Delaware hurricane stagefrequency analysis," Miscellaneous Paper CHL-97-1, U.S. Army Engineer Waterways Experiment Station, Vicksburg, MS.

Militello, A., and Scheffner, N. W. (1998). "Hurricane-induced stage-frequency relationships for the Territory of American Samoa," Technical Report CHL-98-33, U.S. Army Engineer Waterways Experiment Station, Vicksburg, MS.

National Imagery and Mapping Agency. (1999). "Digital nautical chart (DNC)," set of CD-ROM disks, U.S. Department of Defense. 
Resio, D. T., and Perrie, W. (1989). "Implications of an $\mathrm{f}^{4}$ equilibrium range for wind-generated waves," Journal of Physical Oceanography 19, 193-204.

Scheffner, N. W., and Borgman, L. E. (1993). "Stochastic time-series representation of wave data," Journal of Waterway, Port, Coastal and Ocean Engineering, American Society of Civil Engineers, 118(4), 337-351.

Scheffner, N. W., Clausner, J. E., Militello, A., Borgman, L. E., Edge, B. L., and Grace, P. J. (1999). "Use and application of the empirical simulation technique: User's guide,” Technical Report CHL-99-21, U.S. Army Engineer Waterways Experiment Station, Vicksburg, MS.

Seelig, W. N. (1983). "Laboratory study of reef-lagoon system hydraulics," Journal of Waterway, Port, Coastal and Ocean Engineering 109(4), 380391.

Shore protection manual. (1984). $4^{\text {th }}$ ed., 2 Vol., U.S. Army Engineer Waterways Experiment Station, U.S. Government Printing Office, Washington, DC.

Smith, J. M. (1993). "Nearshore wave breaking and decay," Technical Report CERC-93-11, U.S. Army Engineer Waterways Experiment Station, Vicksburg, MS.

Thompson, E. F., and Cardone, V. J. (1996). "Practical modeling of hurricane surface wind fields," Journal of Waterway, Port, Coastal and Ocean Engineering 122(4), 195-205.

Thompson, E. F., and Scheffner, N. W. (in preparation). "Typhoon-induced stage-frequency relationships for the island of Rota," Technical Report CHL-00-xx, U.S. Army Engineer Research and Development Center, Vicksburg, MS.

U.S. Army Engineer Division, Pacific Ocean. (1995). "Commercial Port Road, Territory of Guam, Storm Damage Reduction Study, Feasibility Report \& Environmental Assessment, Final Report," U.S. Army Corps of Engineers, Pacific Ocean Division.

van der Meer, J. W., and Janssen, J. P. F. M. (1994). "Wave run-up and wave overtopping at dikes and revetments," Report Number 485, Delft Hydraulics, Delft, The Netherlands.

Ward, D. L., and Ahrens, J. P. (1992). "Overtopping rates for seawalls," Miscellaneous Paper CERC-92-3, U.S. Army Engineer Waterways Experiment Station, Vicksburg, MS.

Westerink, J. J., Luettich, R. A., Baptista, A. M., Scheffner, N. W., and Farrar, P. (1992). "Tide and storm surge predictions using finite element model," Journal of Hydraulic Engineering American Society of Civil Engineers, 118(10), 1373-139. 


\section{Appendix A Typhoon Tracks}

This appendix shows typhoon tracks for each storm contained in the Empirical Simulation Technique (EST) training set. Each figure consists of an upper and lower panel. The upper panel shows storm tracks through the immediate vicinity of the islands of interest for the study. Some figures do not show a storm track in the upper panel because the storm did not pass within the bounds of the graphical limits. The lower panel shows storm tracks for the region covered by the numerical grid developed for the study. The outer boundary of the numerical grid is shown as the large circle. Storm tracks can also be seen outside of the grid region. Dots in the upper and lower panels show the 6-hr best track locations for the storms. 


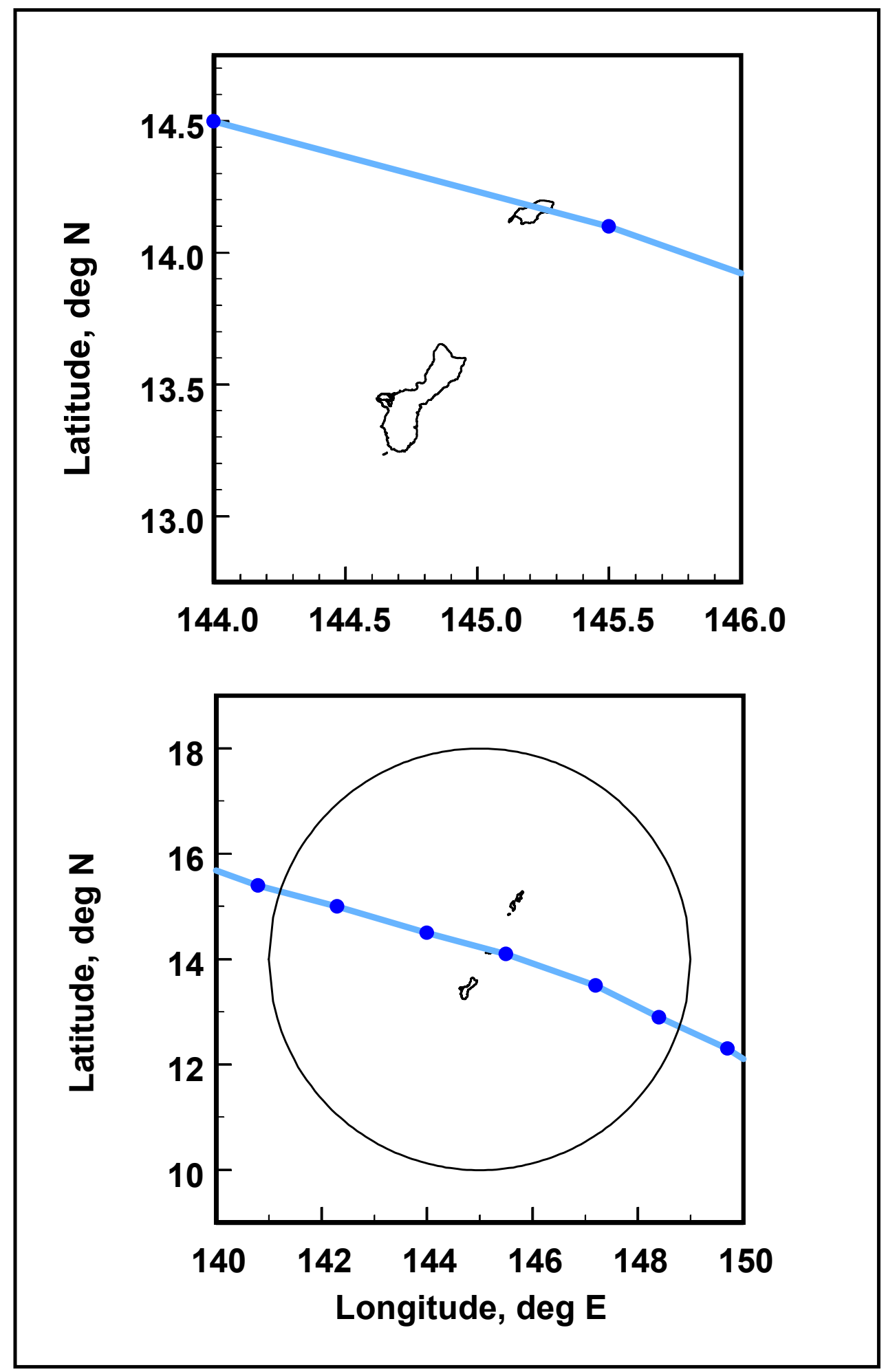

Figure A1. Storm track for Agnes (2348) 


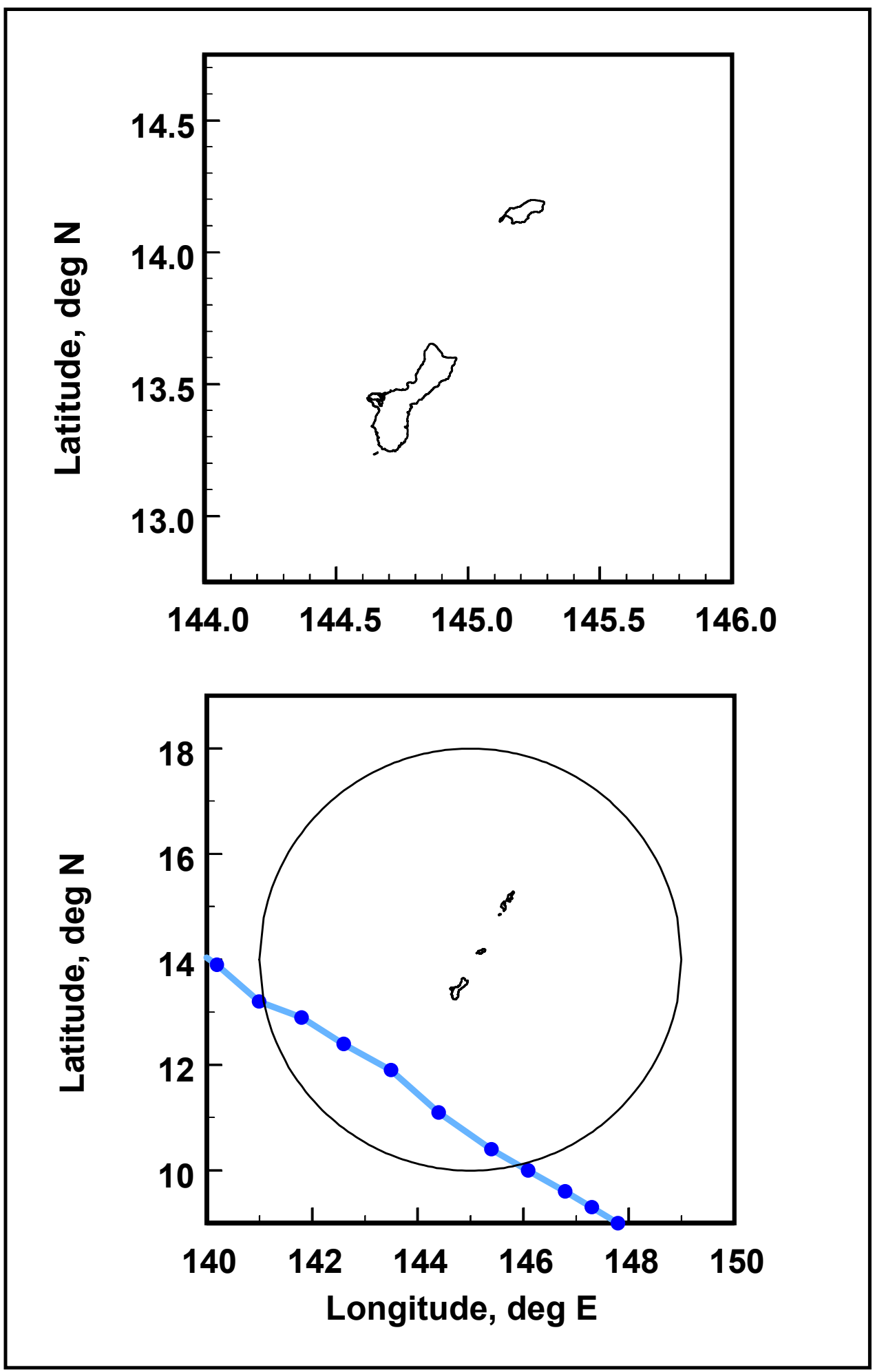

Figure A2. Storm track for Doris (0150) 


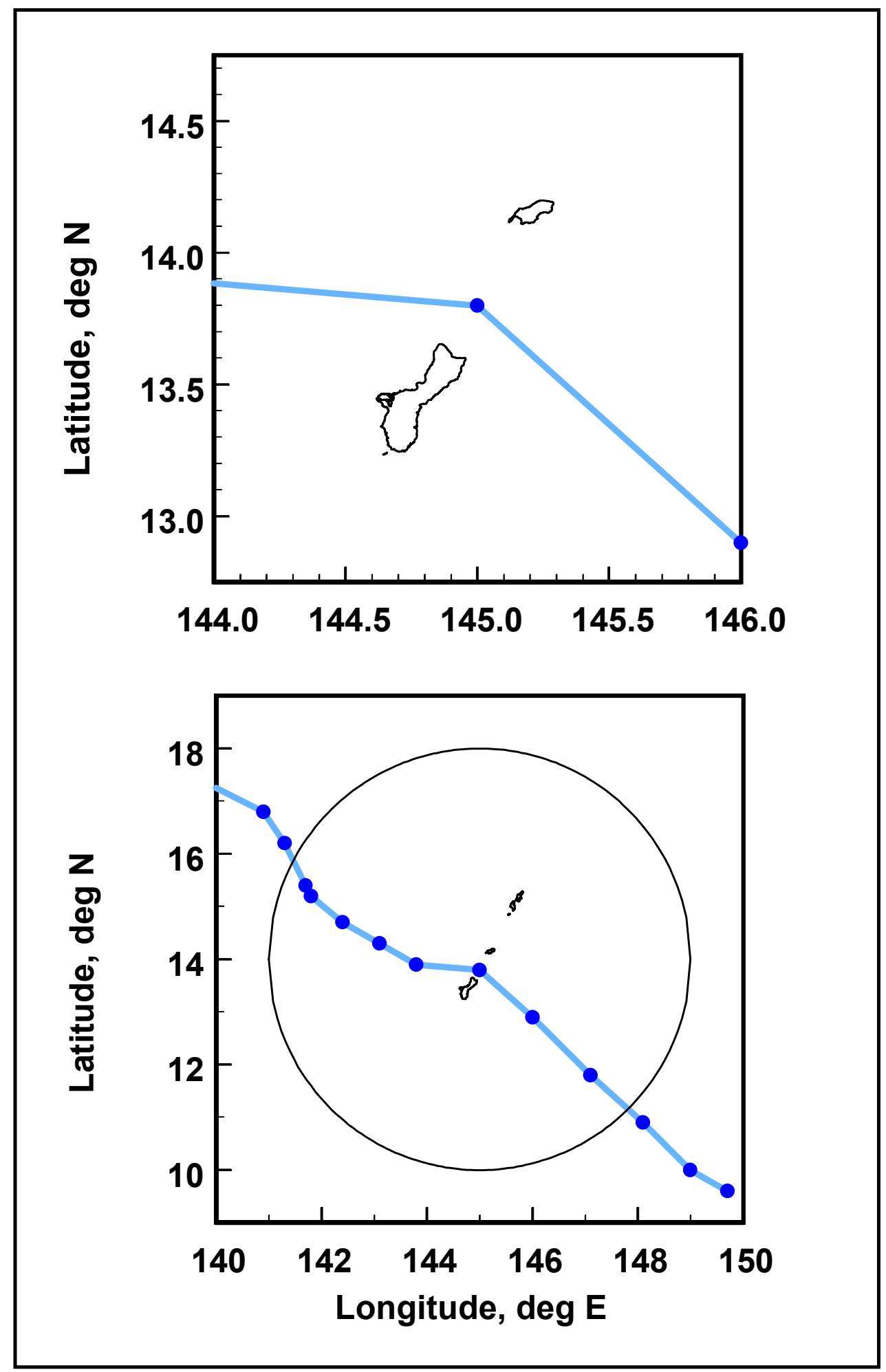

Figure A3. Storm track for Nina (0853) 


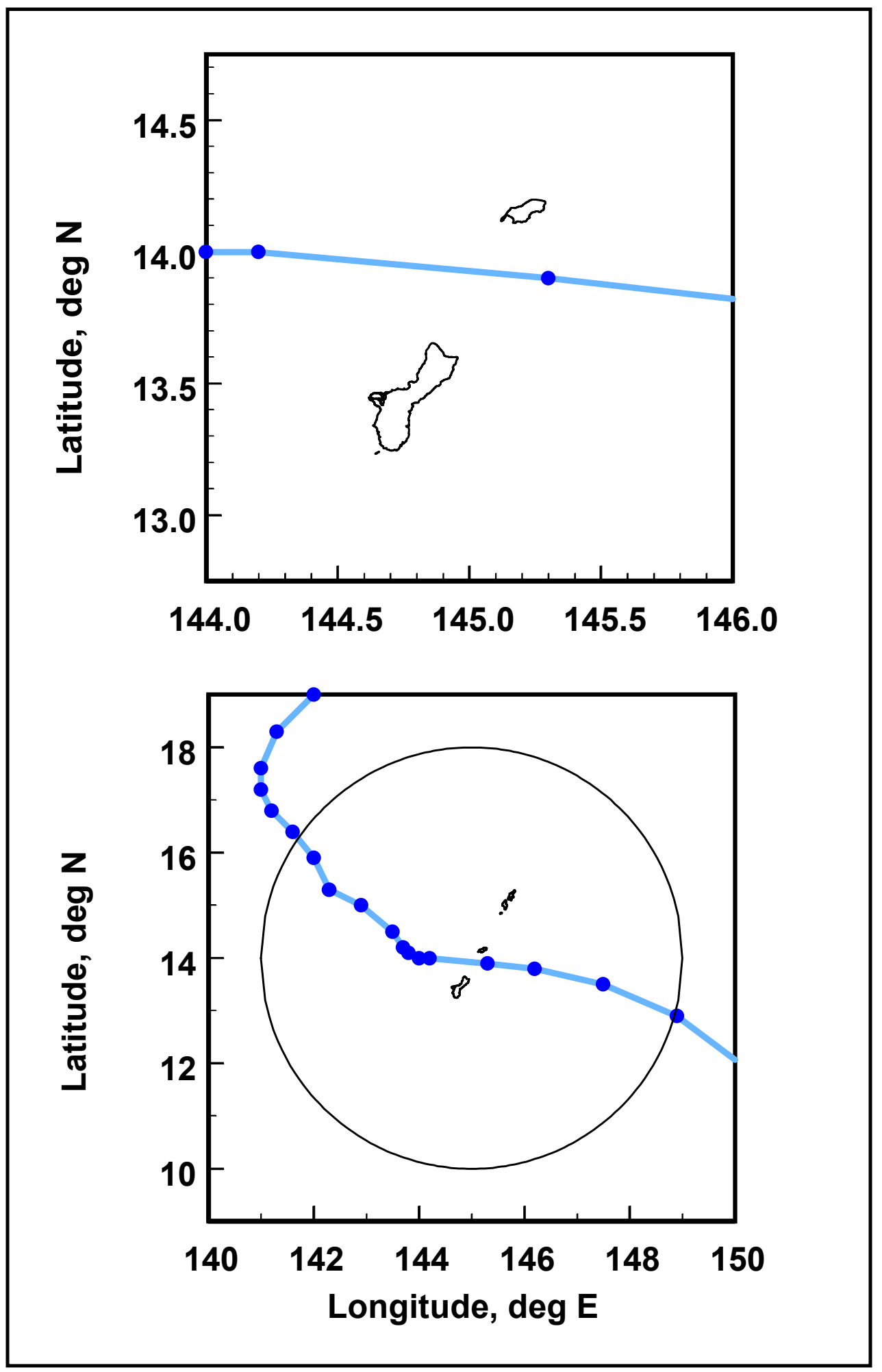

Figure A4. Storm track for Alice (1953) 


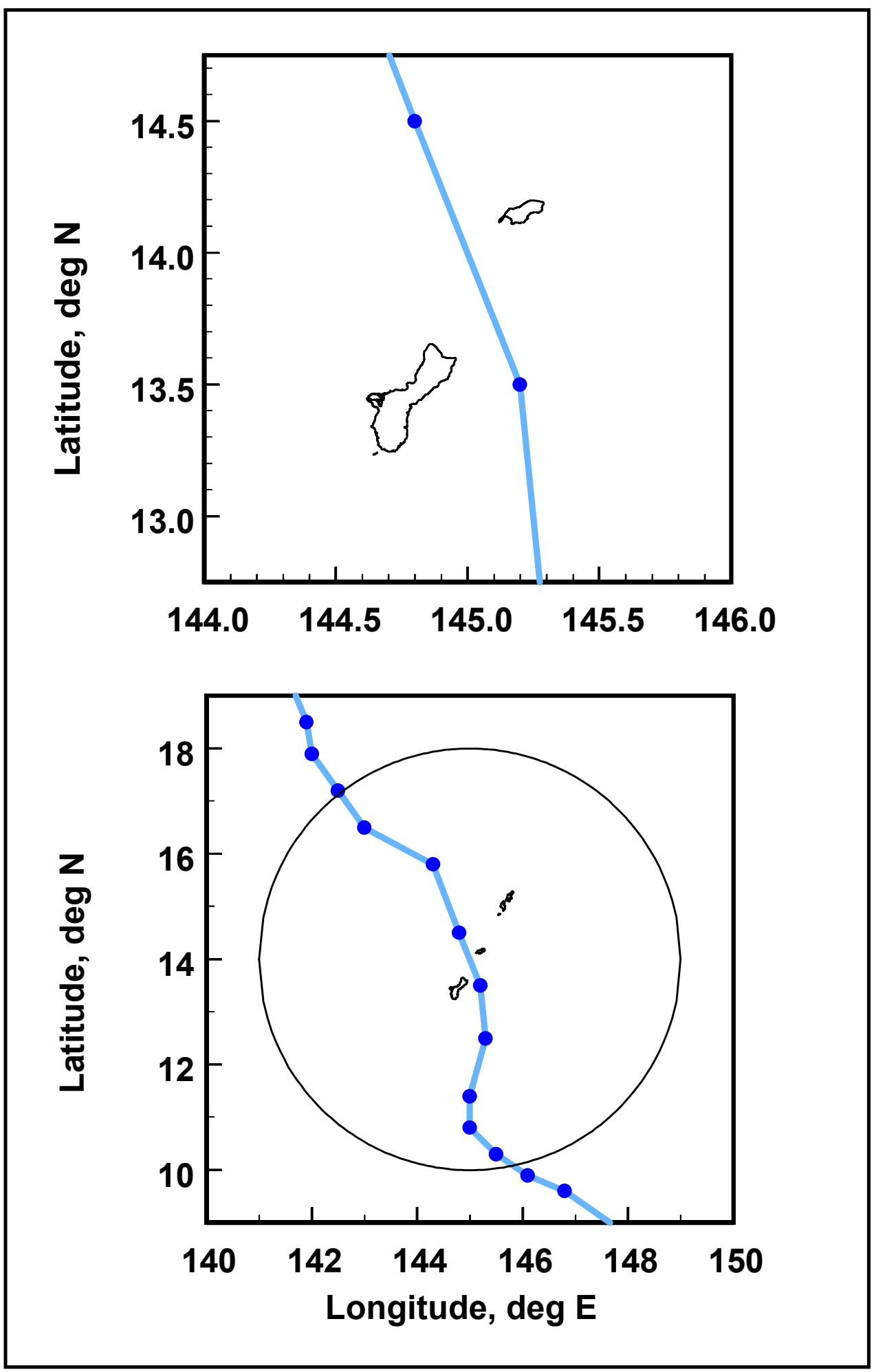

Figure A5. Storm track for Hester (1557) 


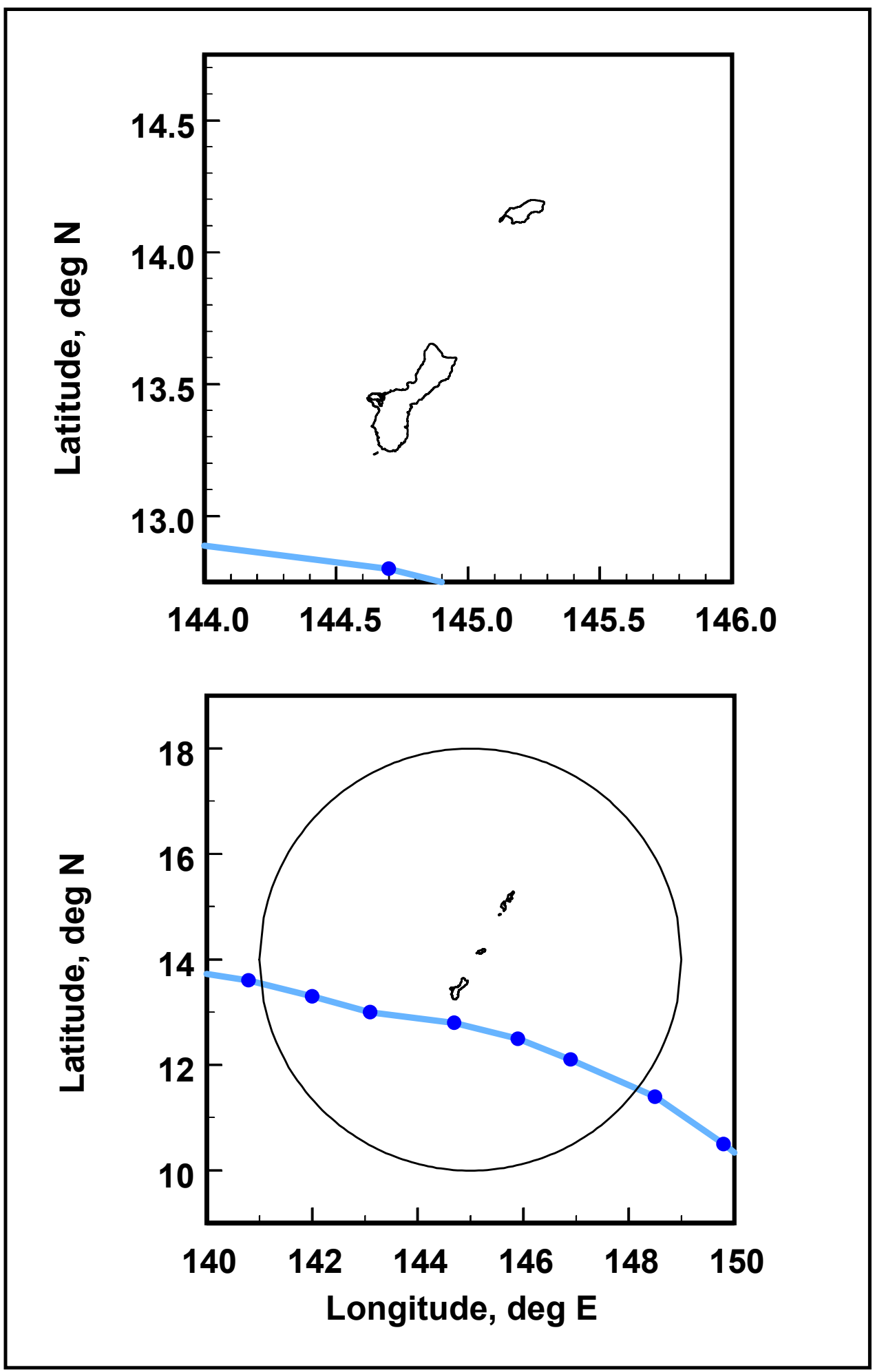

Figure A6. Storm track for Lola (2057) 


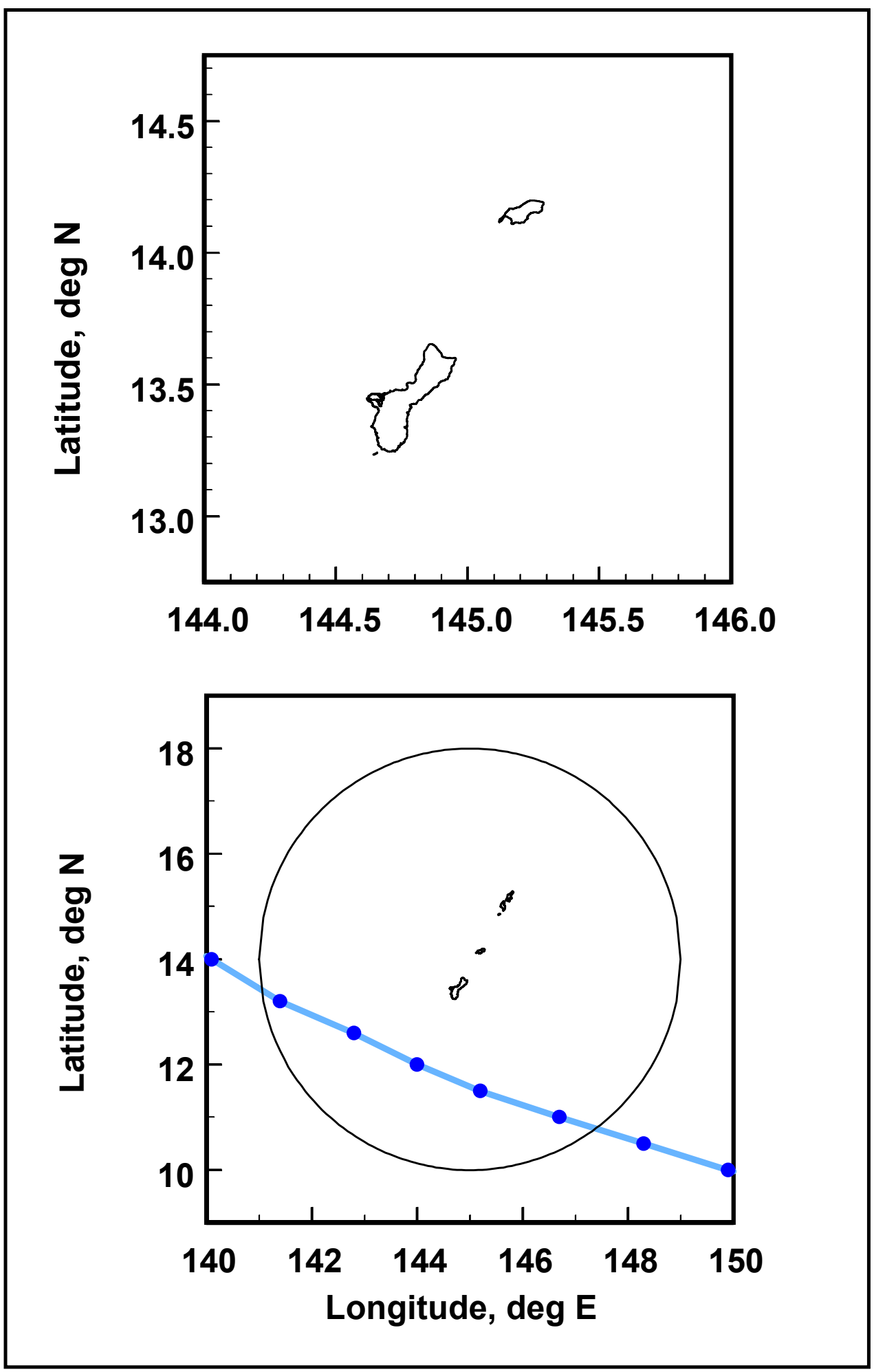

Figure A7. Storm track for Nancy (1861) 


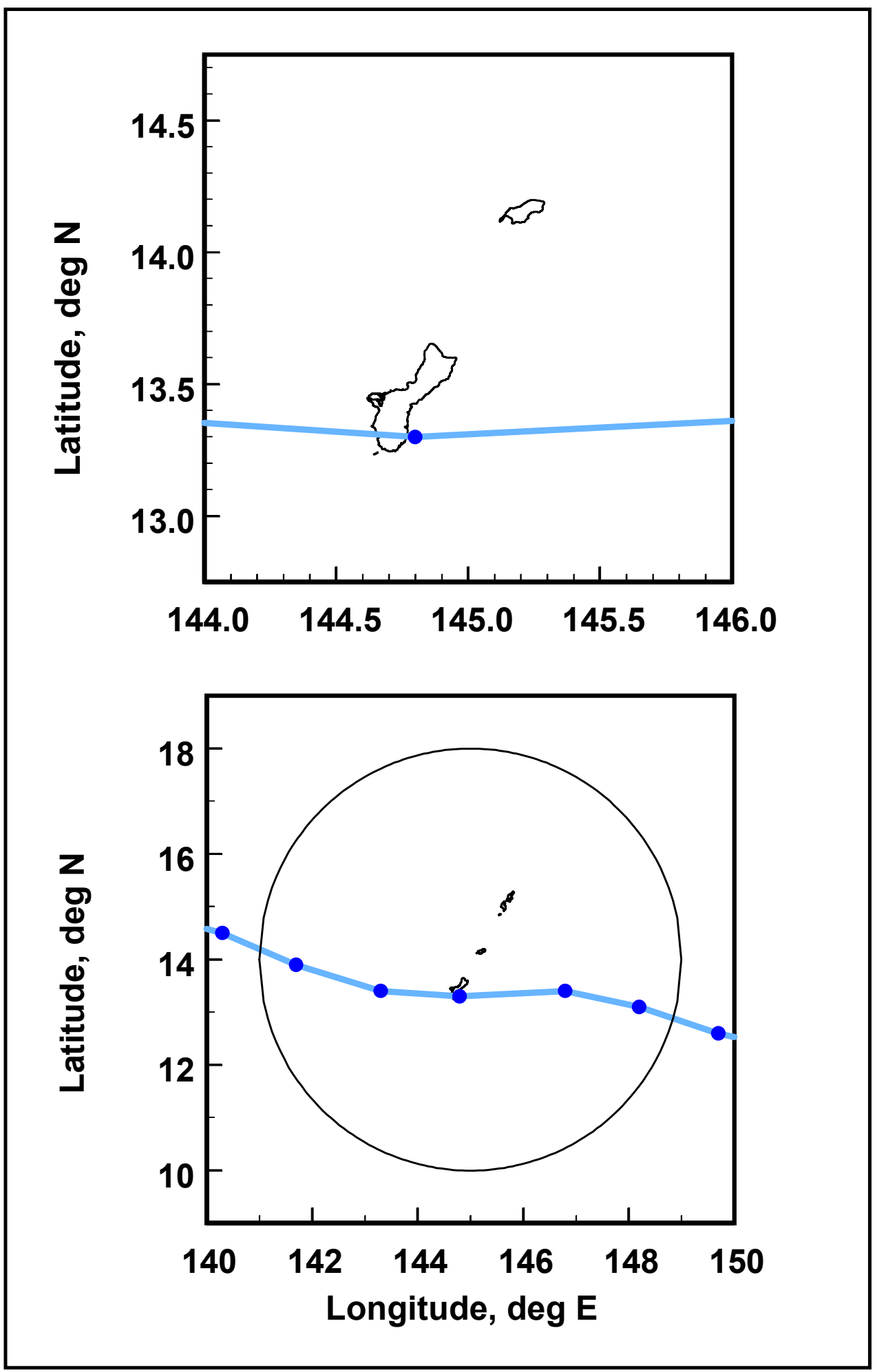

Figure A8. Storm track for Karen (2762) 


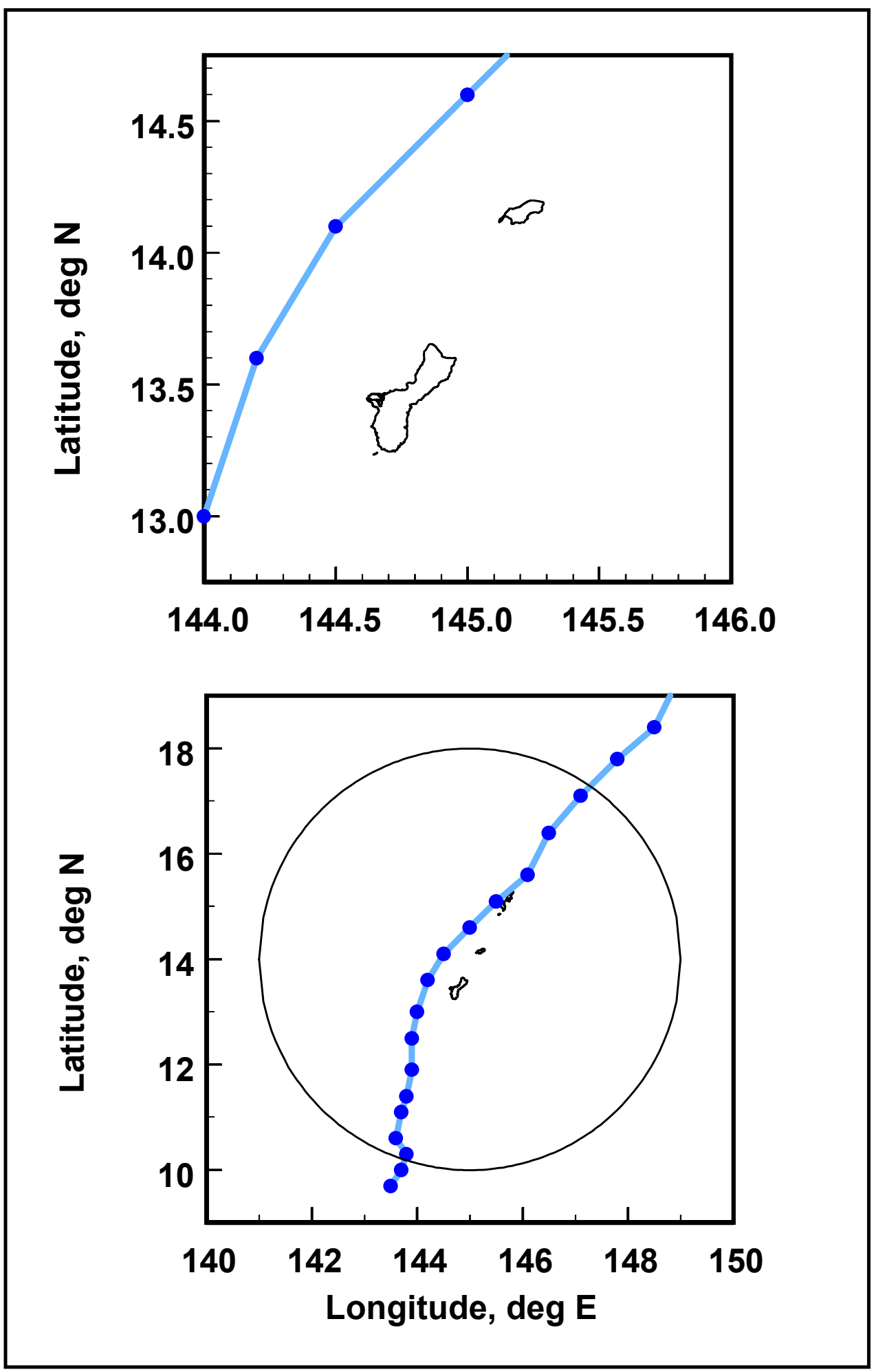

Figure A9. Storm track for Olive (0163) 


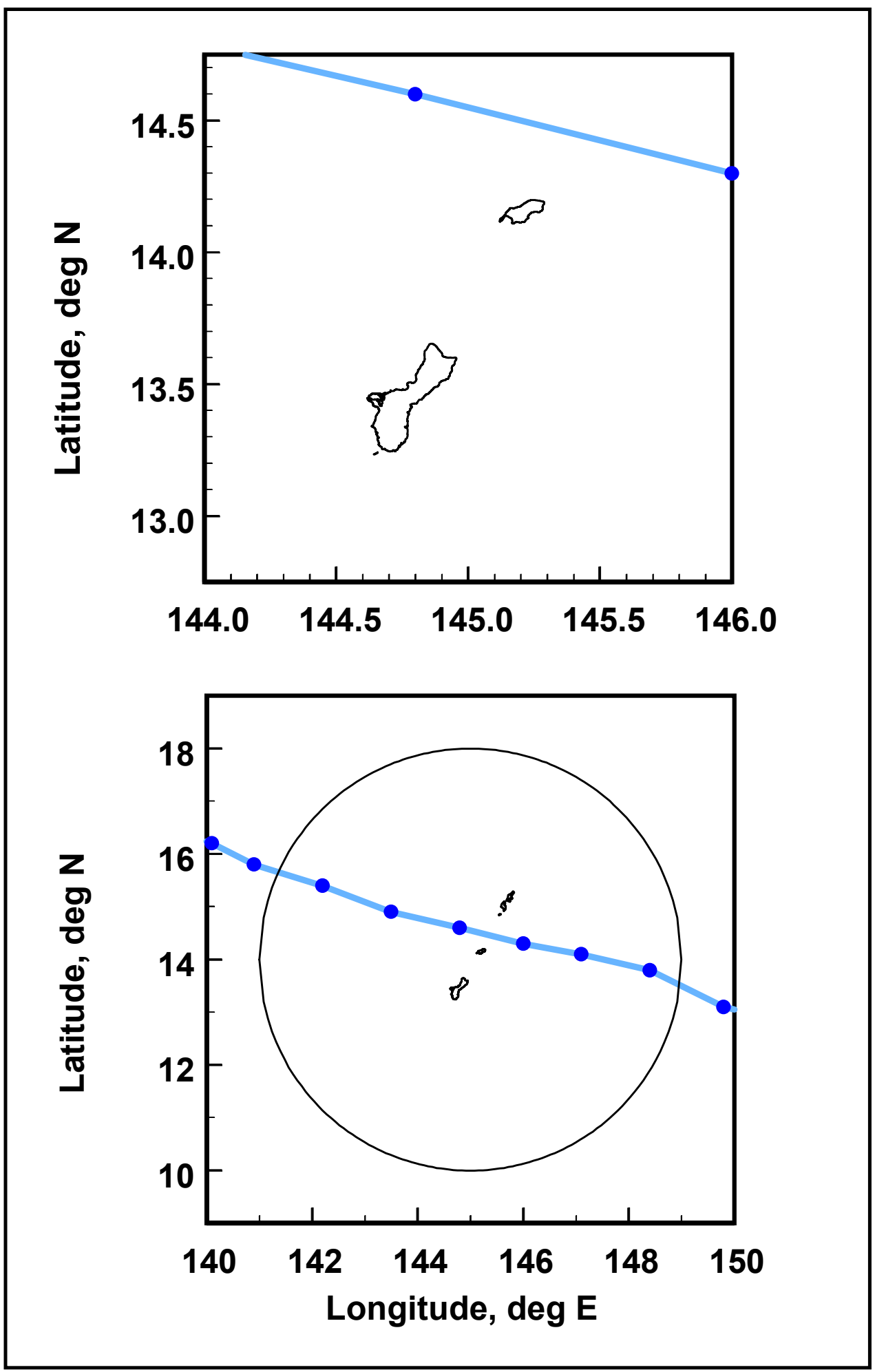

Figure A10. Storm track for Susan (2563) 


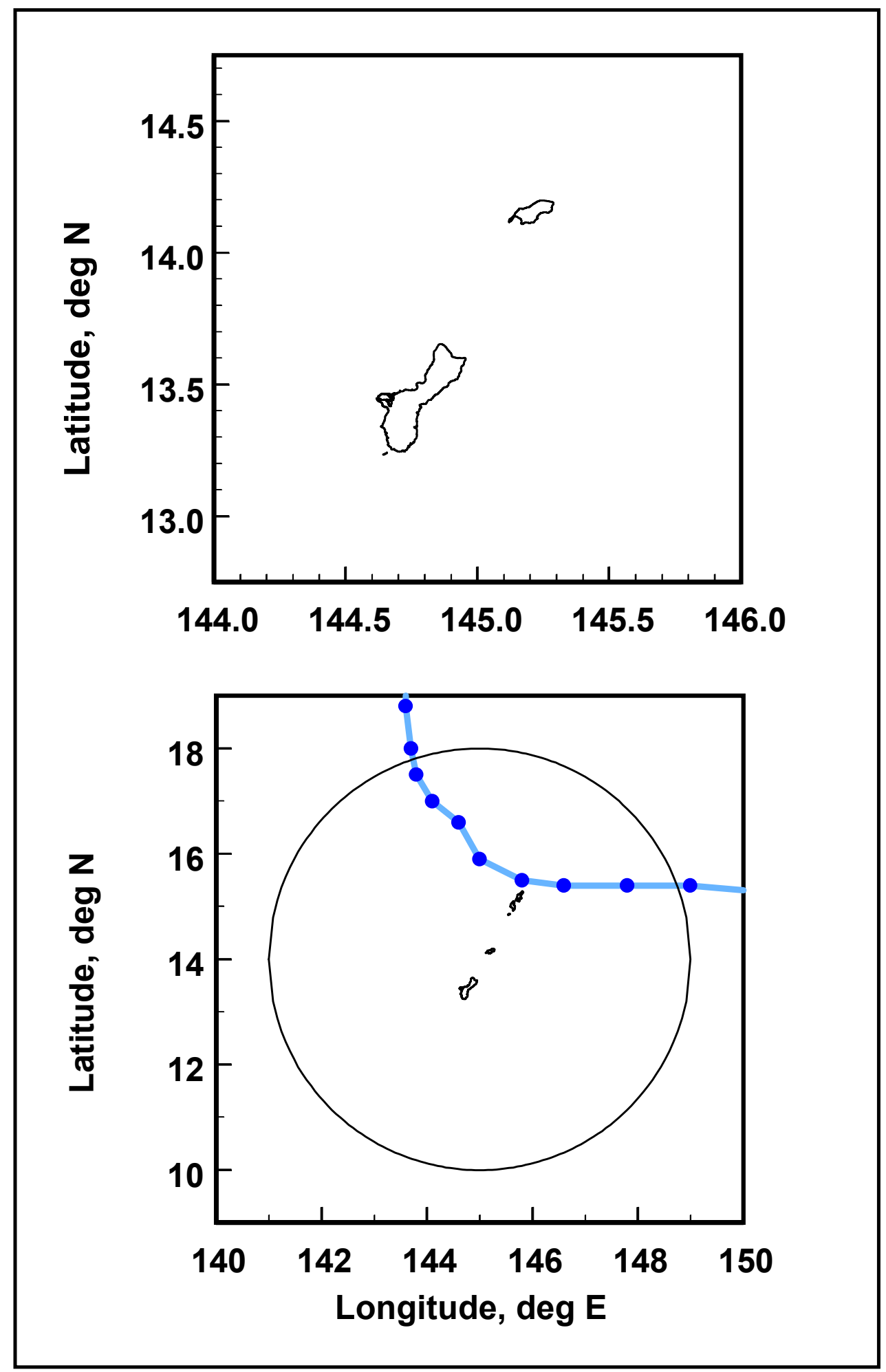

Figure A11. Storm track for Bess (2965) 


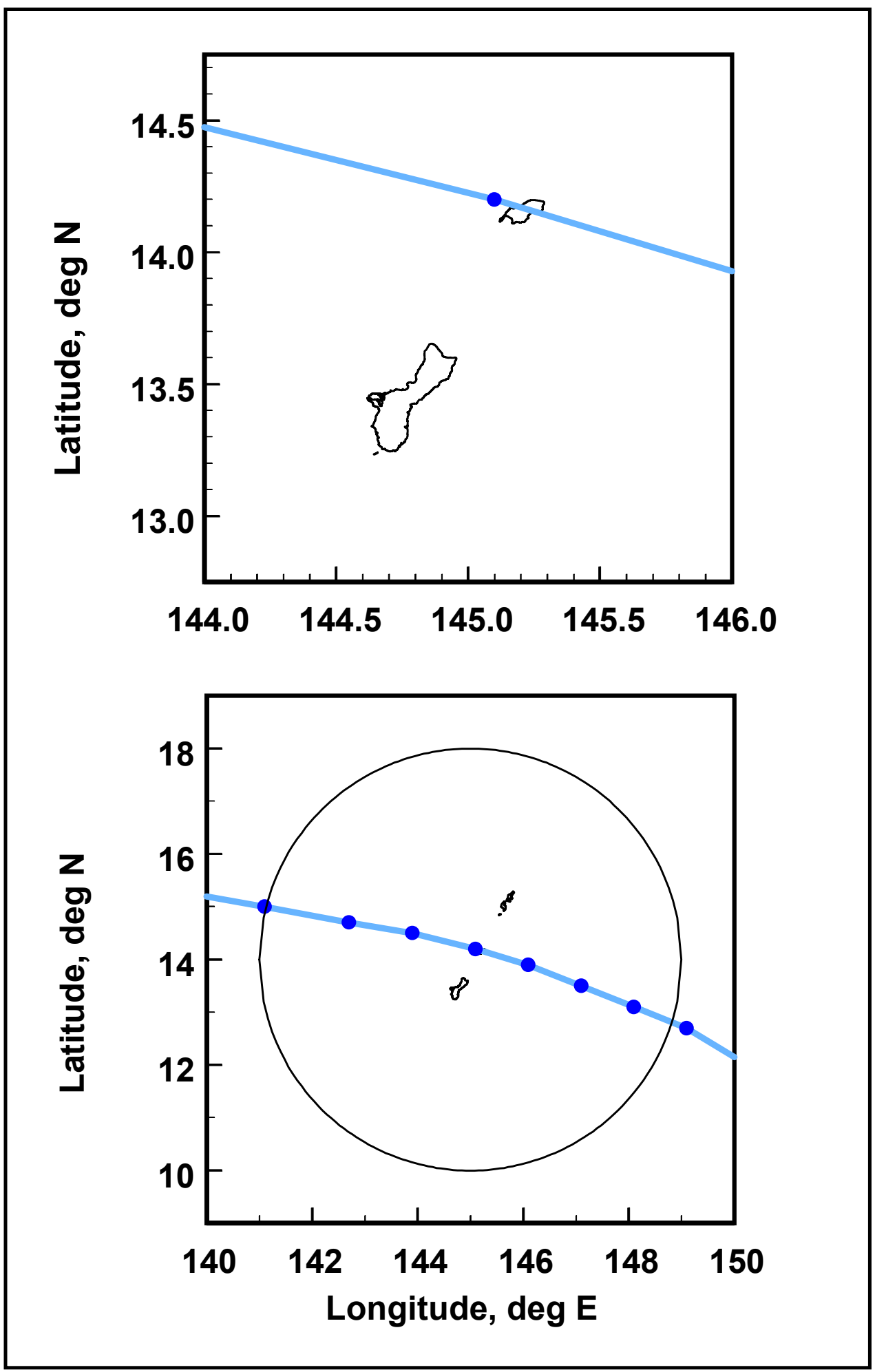

Figure A12. Storm track for Gilda (3367) 


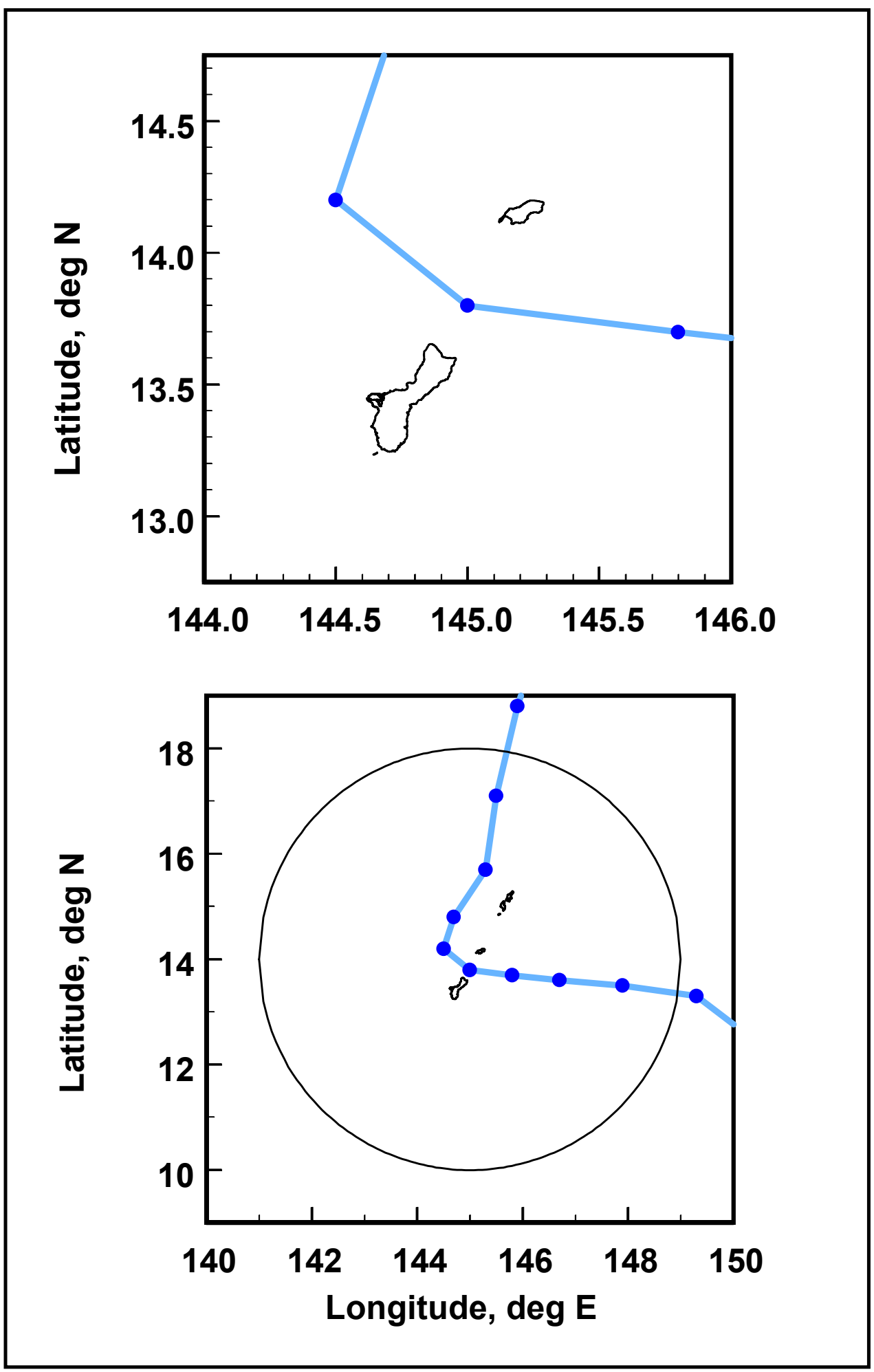

Figure A13. Storm track for Irma (2168) 


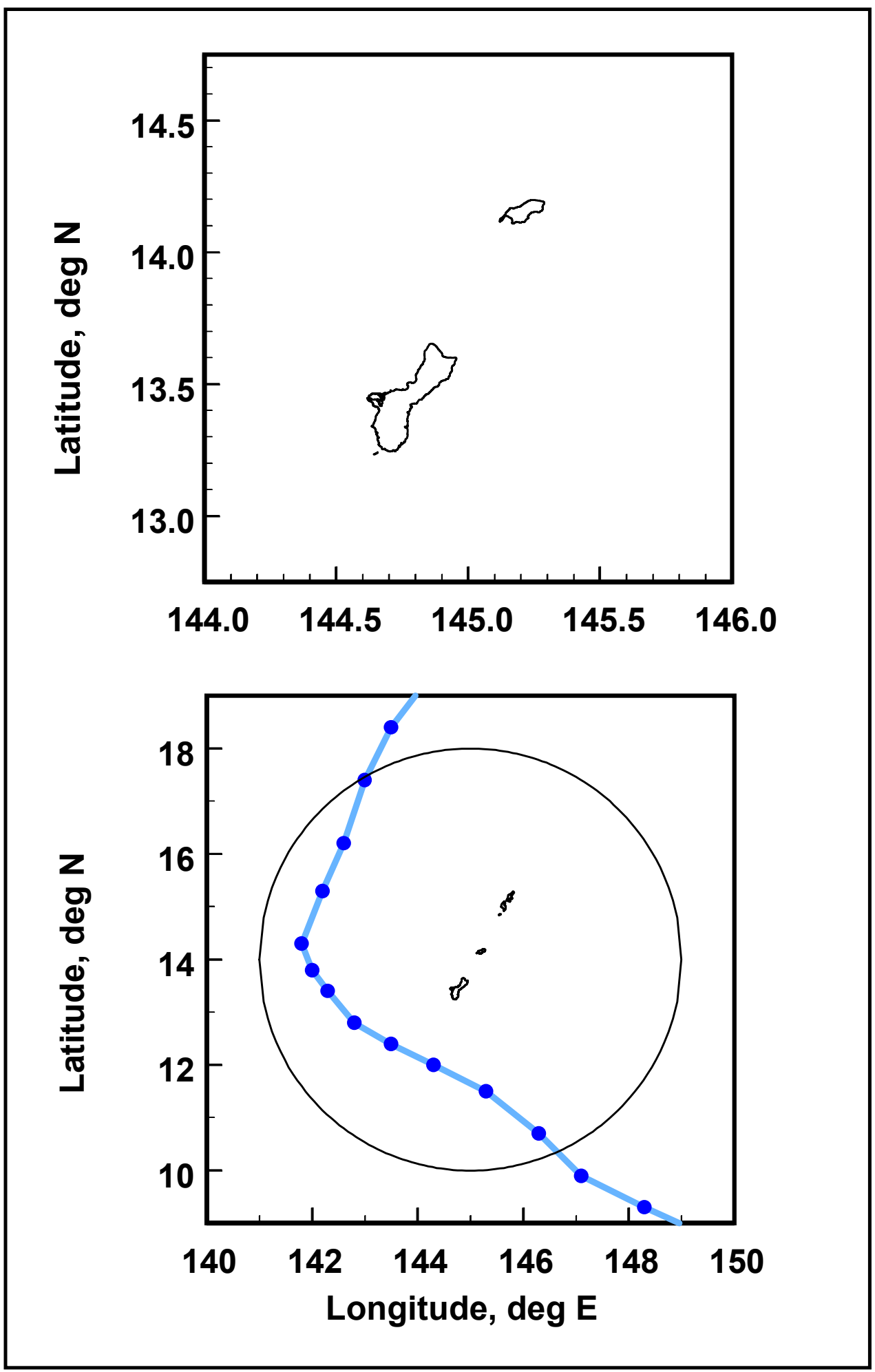

Figure A14. Storm track for Amy (0571) 


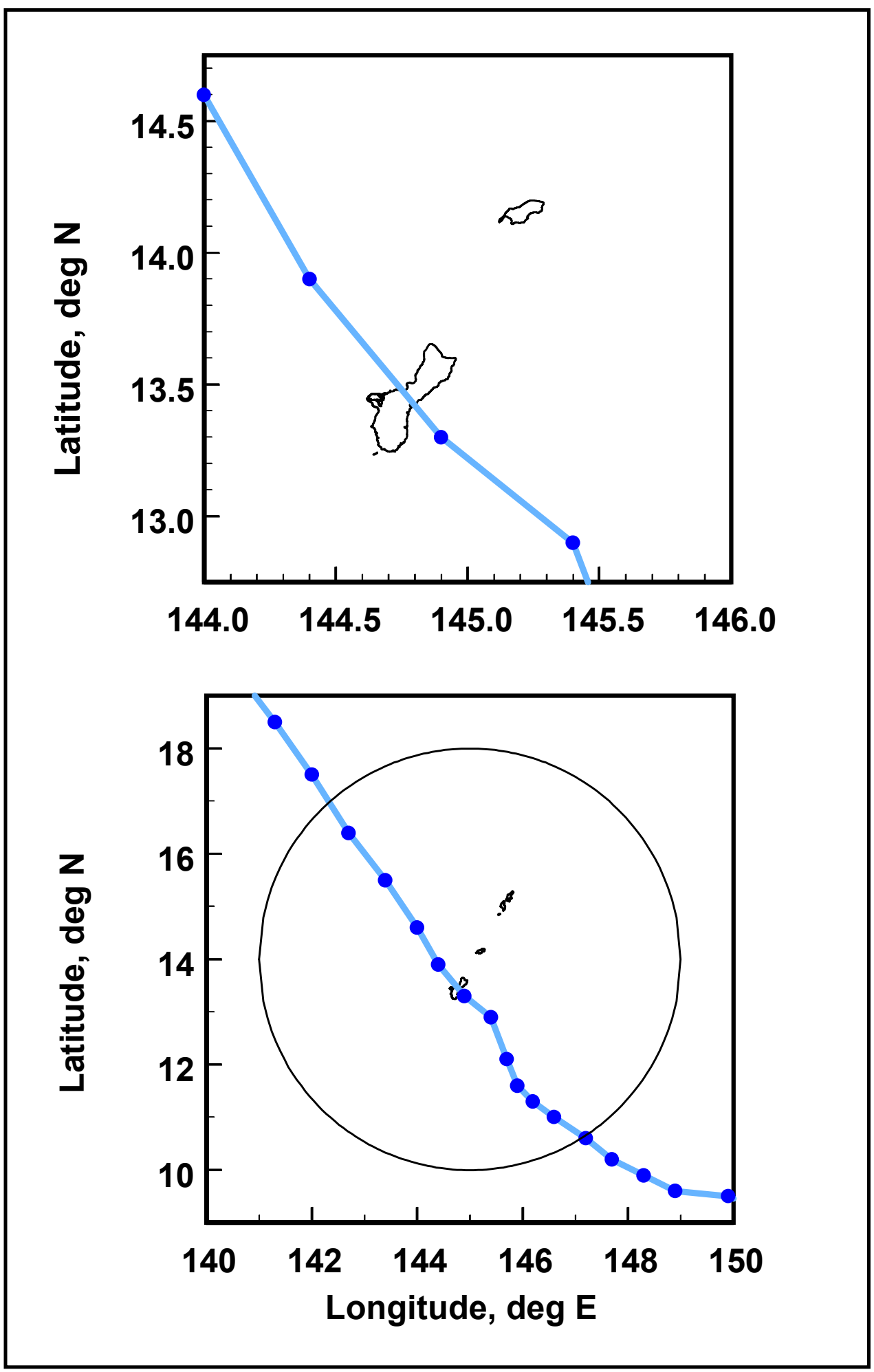

Figure A15. Storm track for Pamela (0676) 


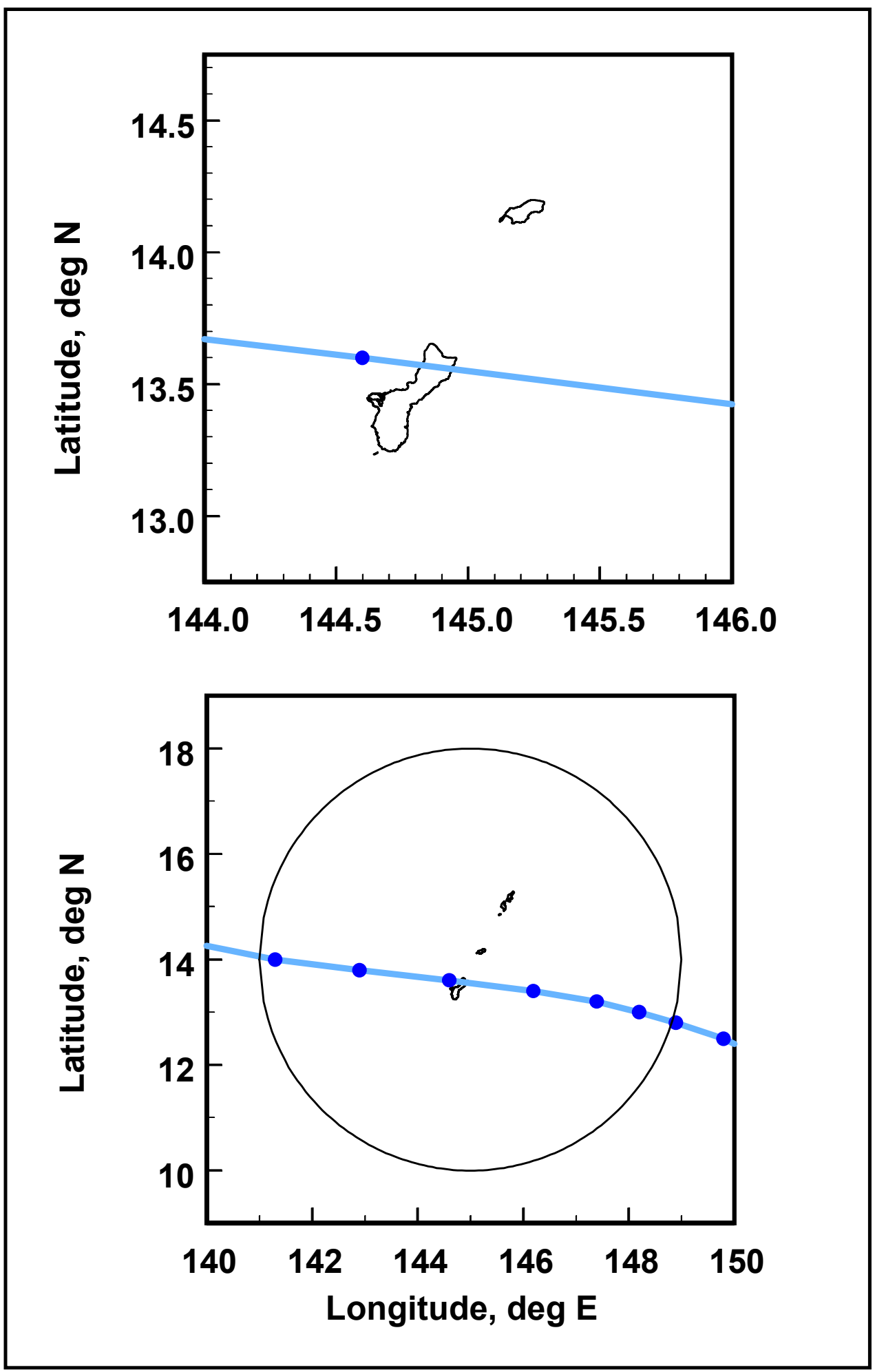

Figure A16. Storm track for Kim (1977) 


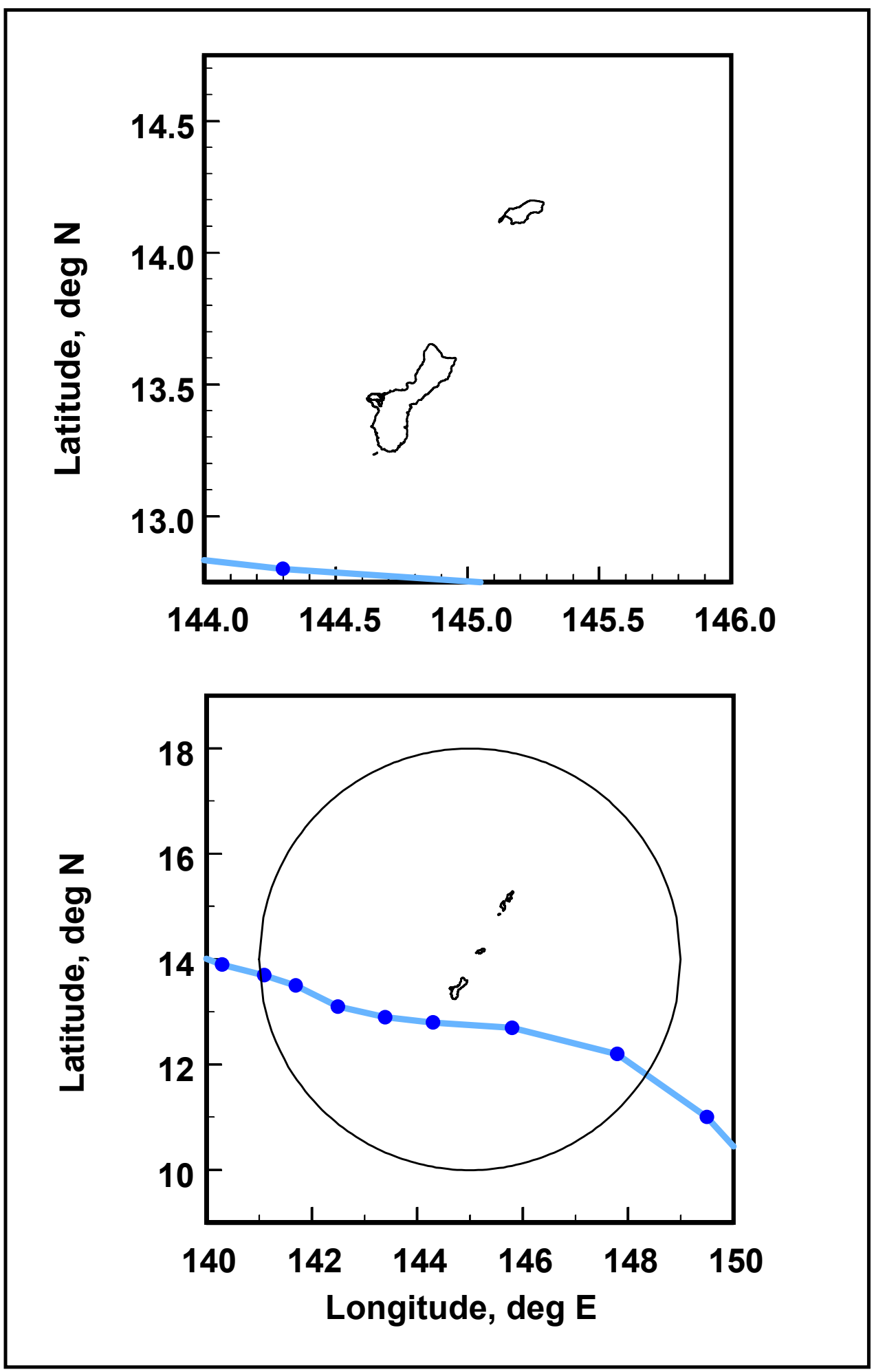

Figure A17. Storm track for Tip (2379) 


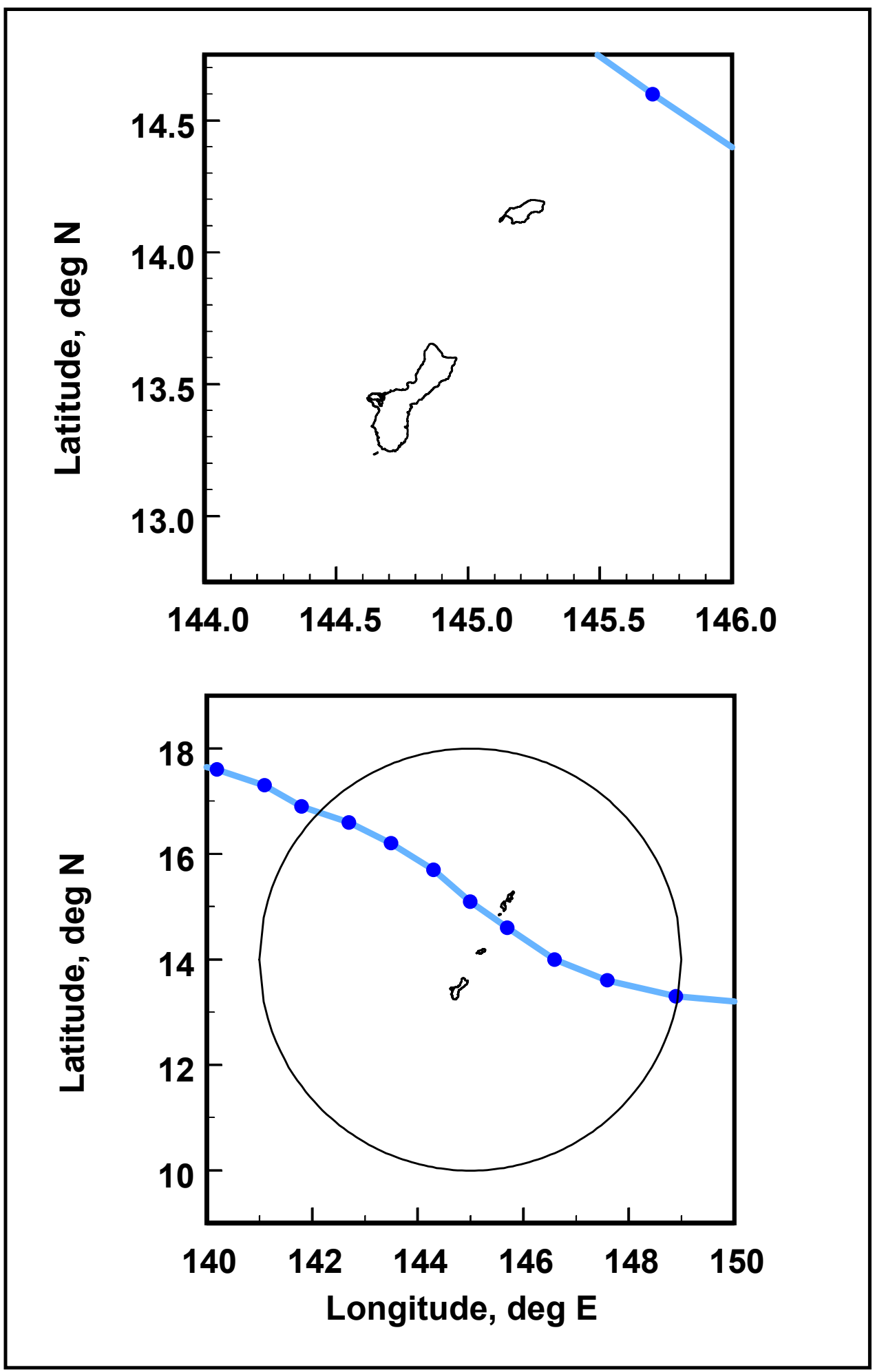

Figure A18. Storm track for Lynn (2187) 


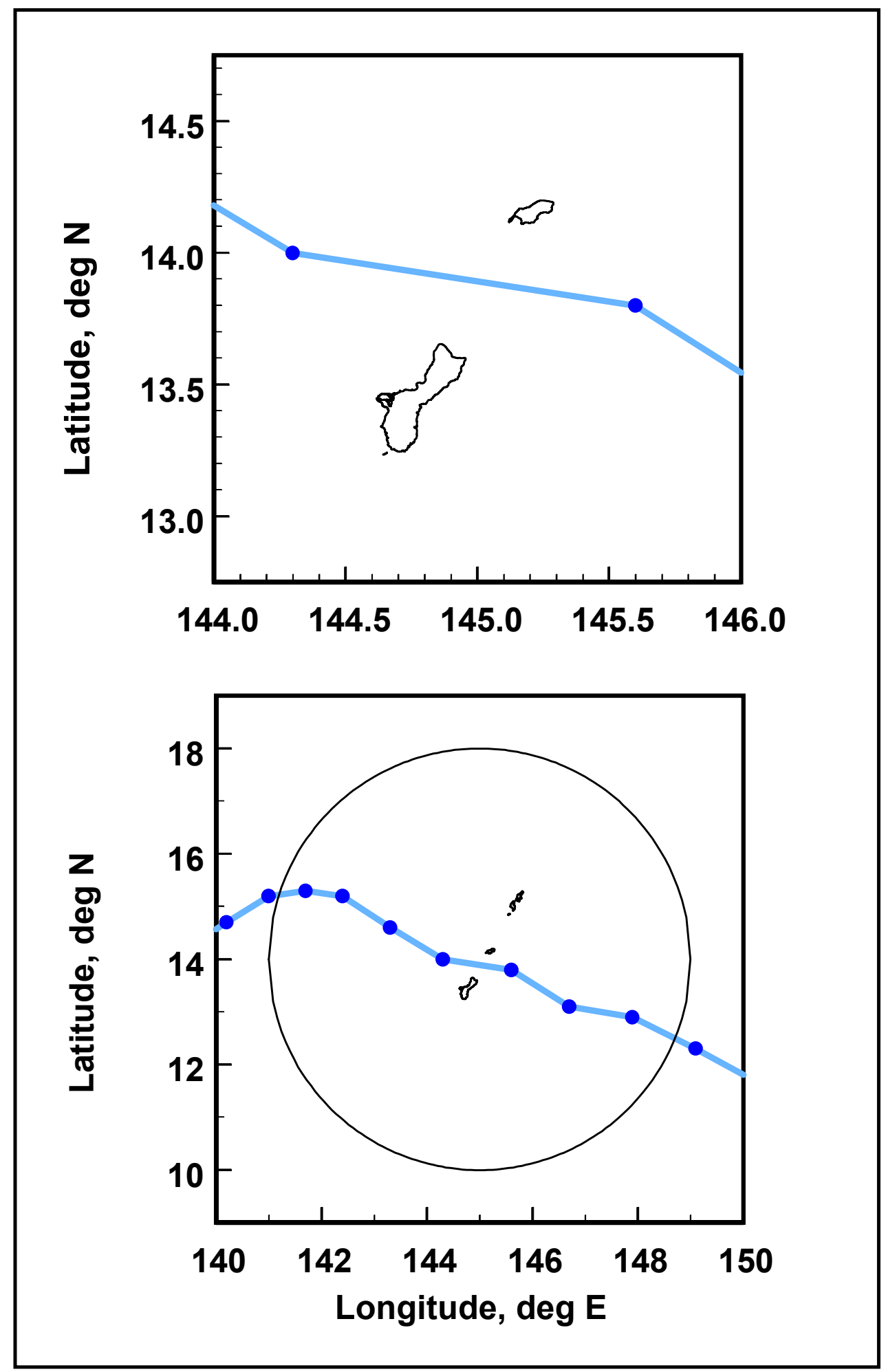

Figure A19. Storm track for Roy (0188) 


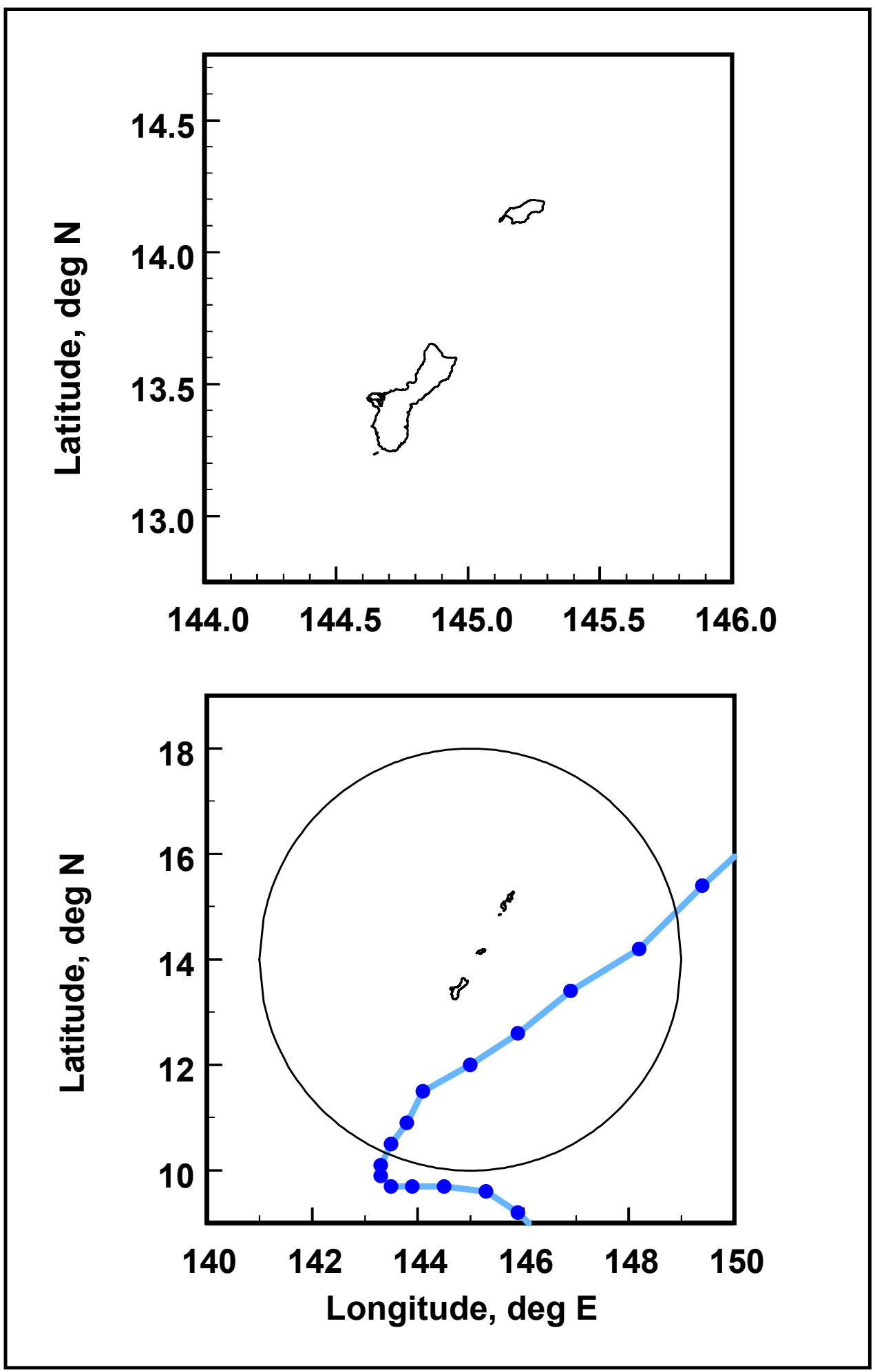

Figure A20. Storm track for Andy (0289) 


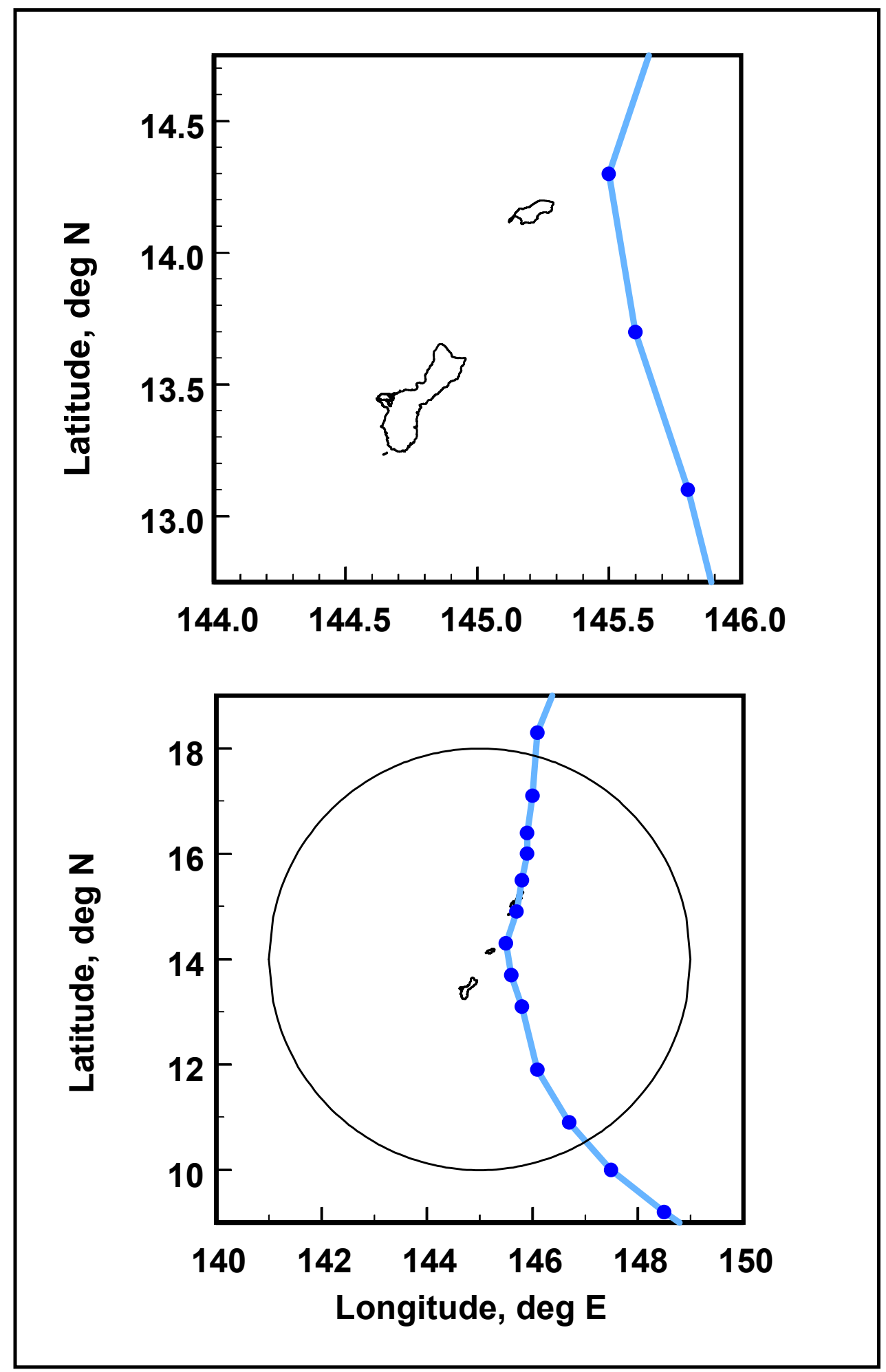

Figure A21. Storm track for Koryn (0190) 


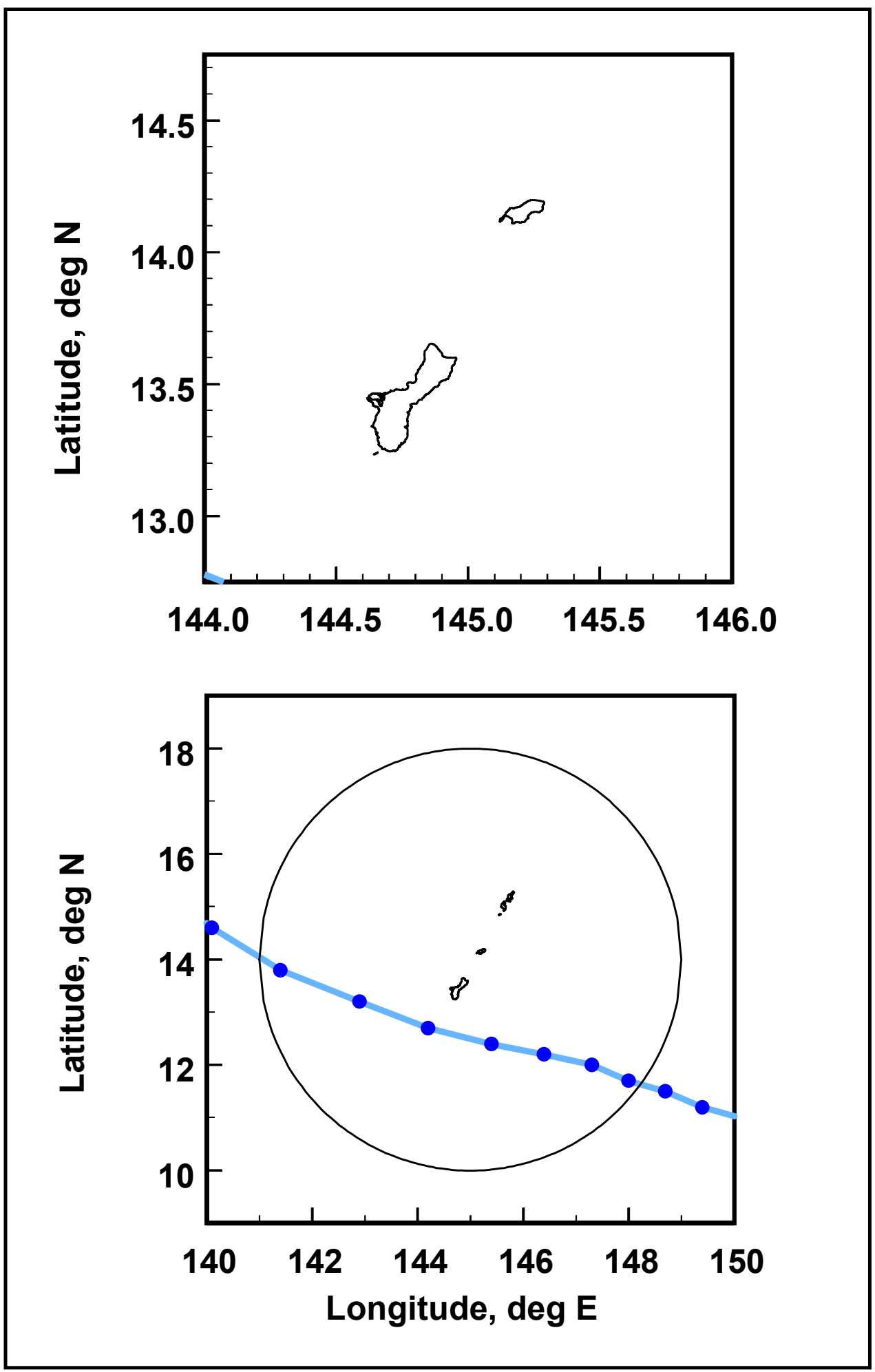

Figure A22. Storm track for Russ (3190) 


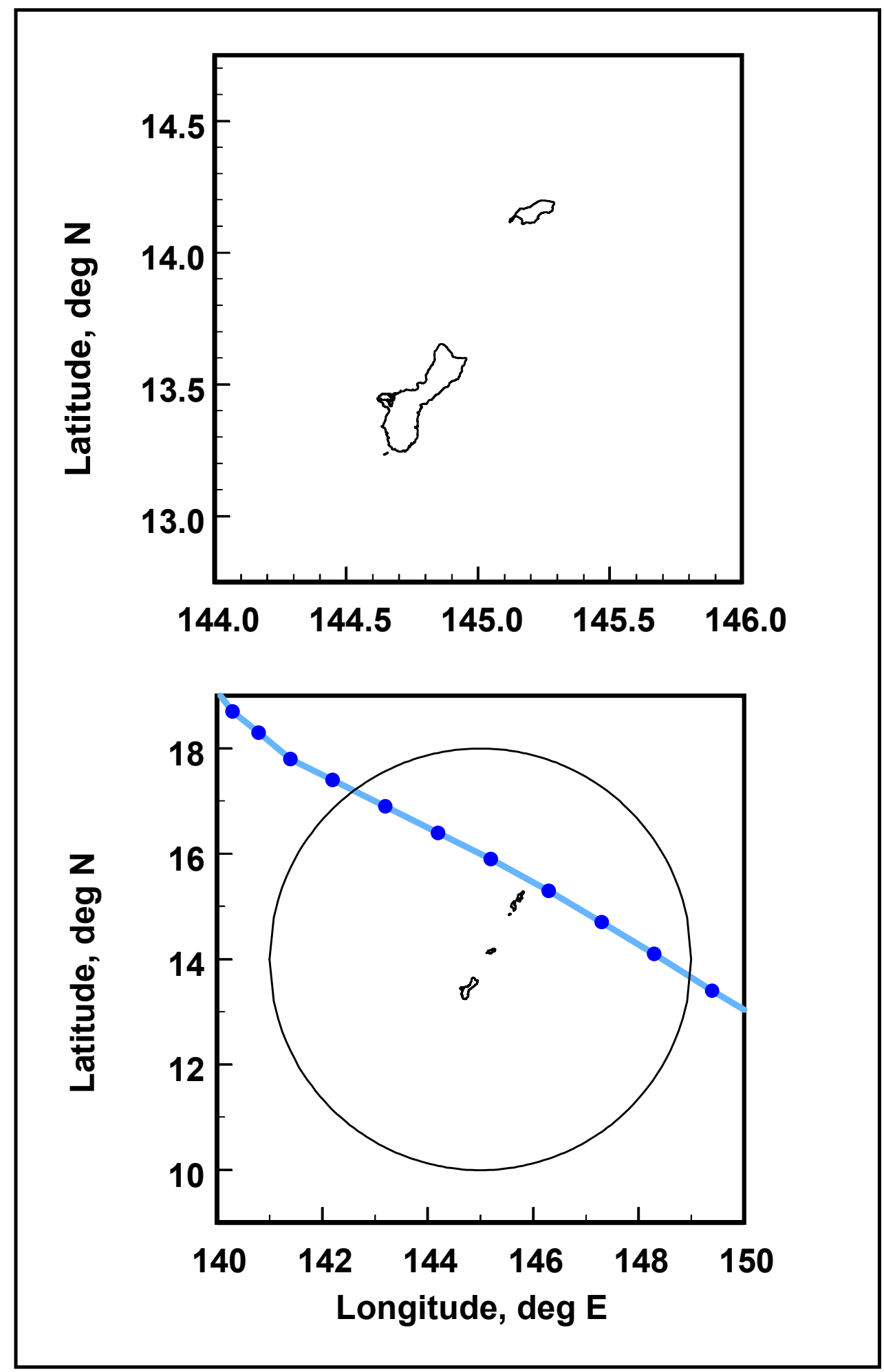

Figure A23. Storm track for Seth (2691) 


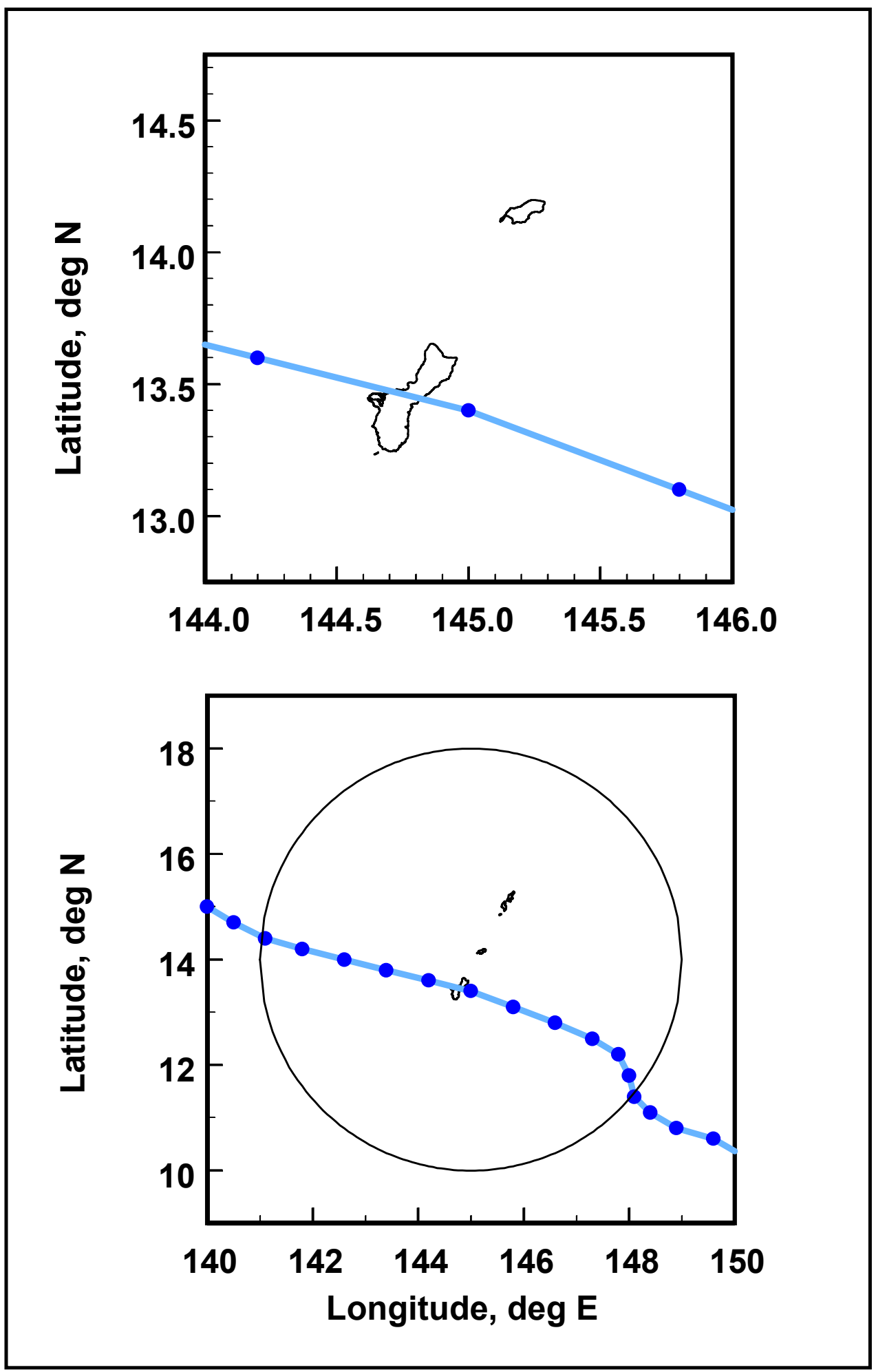

Figure A24. Storm track for Omar (1592) 


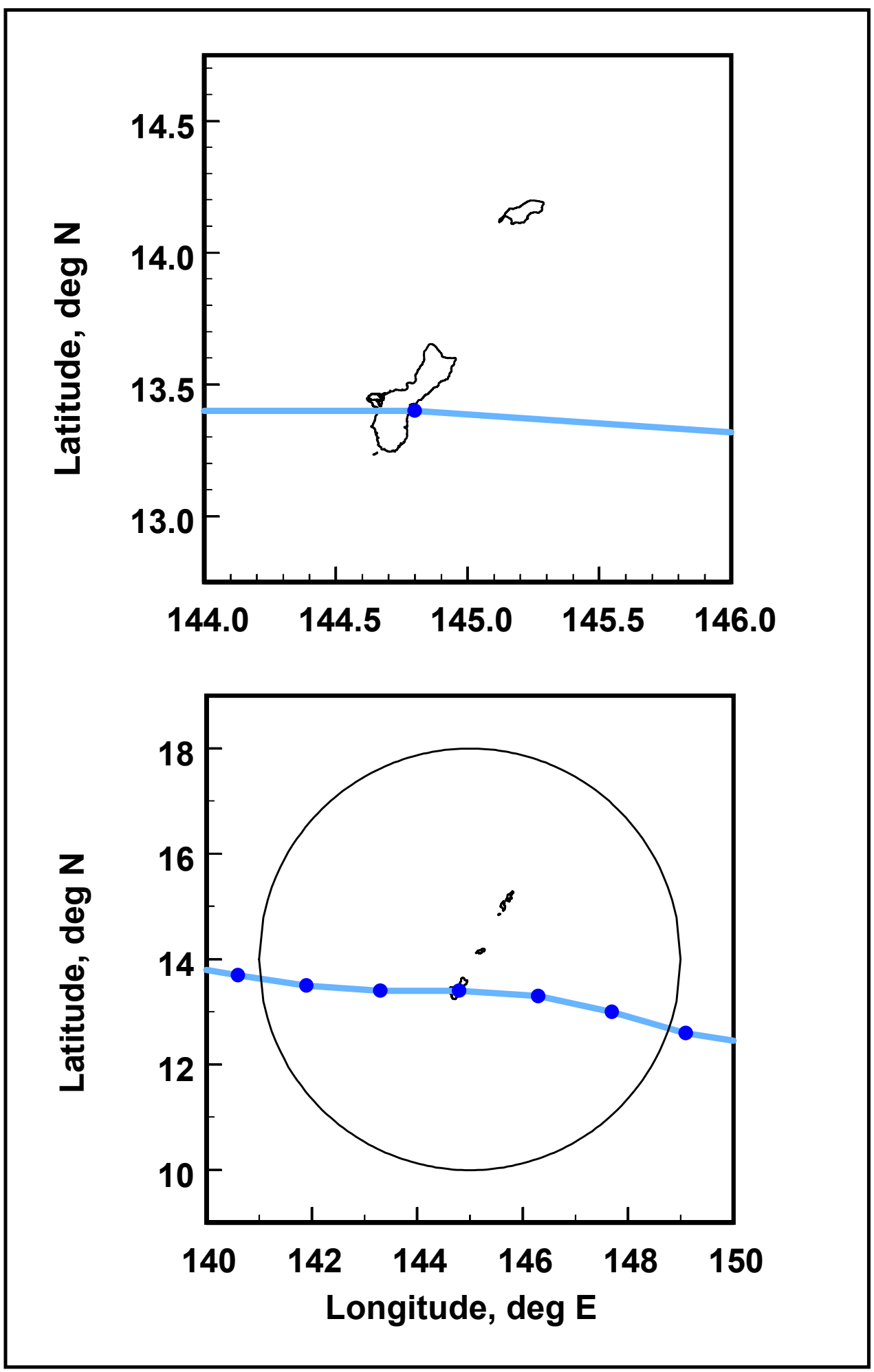

Figure A25. Storm track for Gay (3192) 


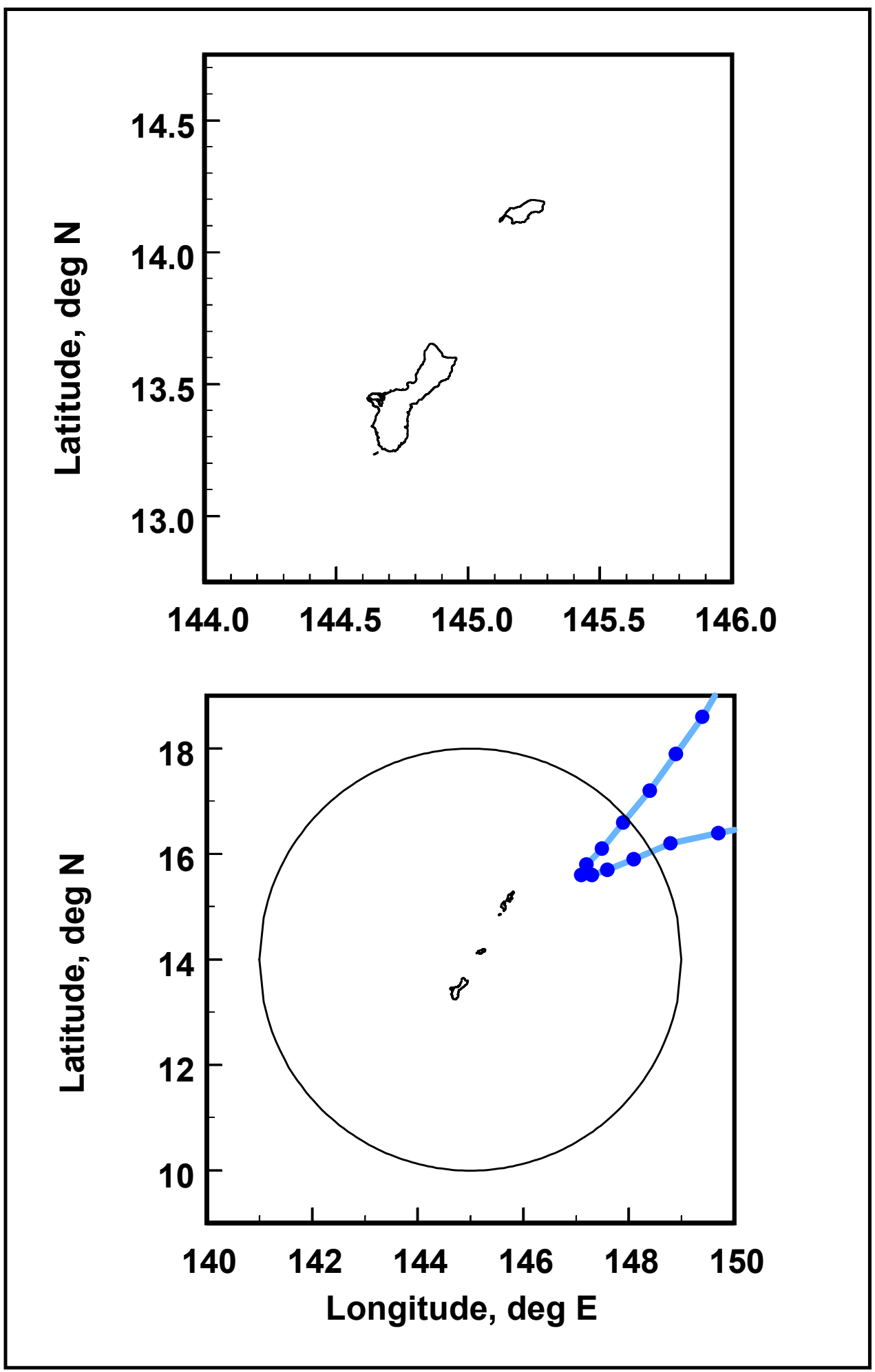

Figure A26. Storm track for Wilda (3594) 


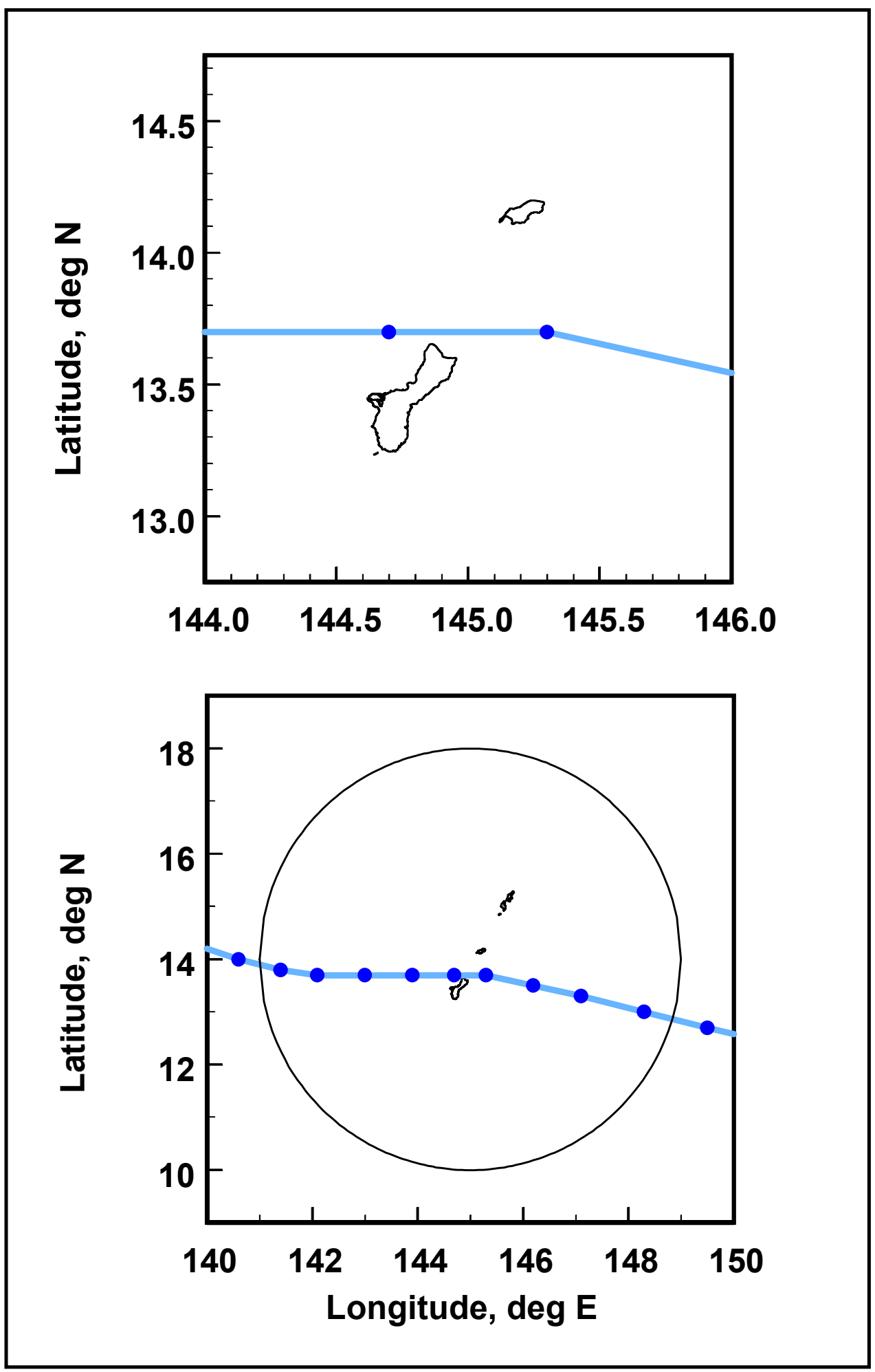

Figure A27. Storm track for Paka (0597) 


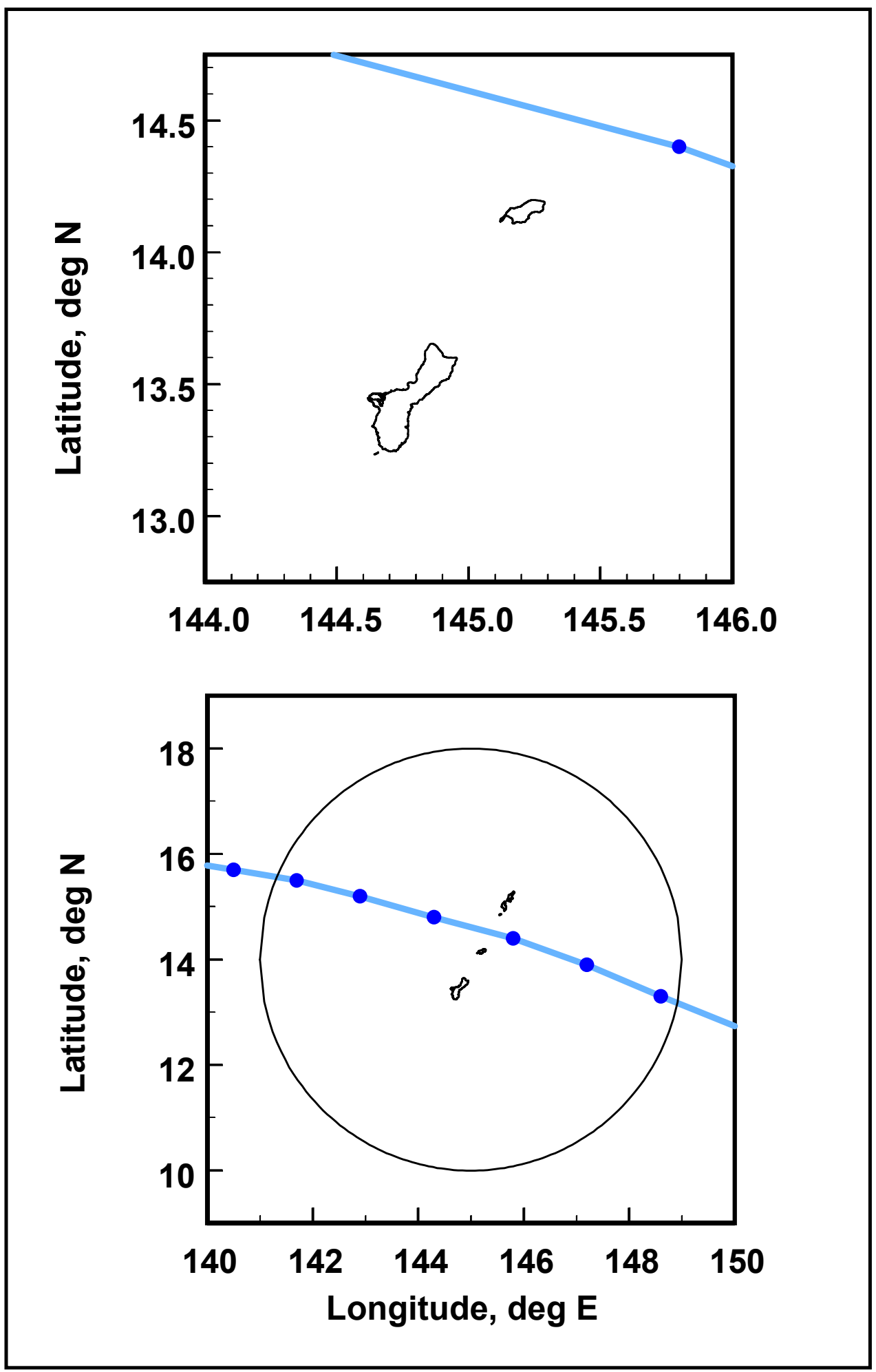

Figure A28. Storm track for Keith (2997) 


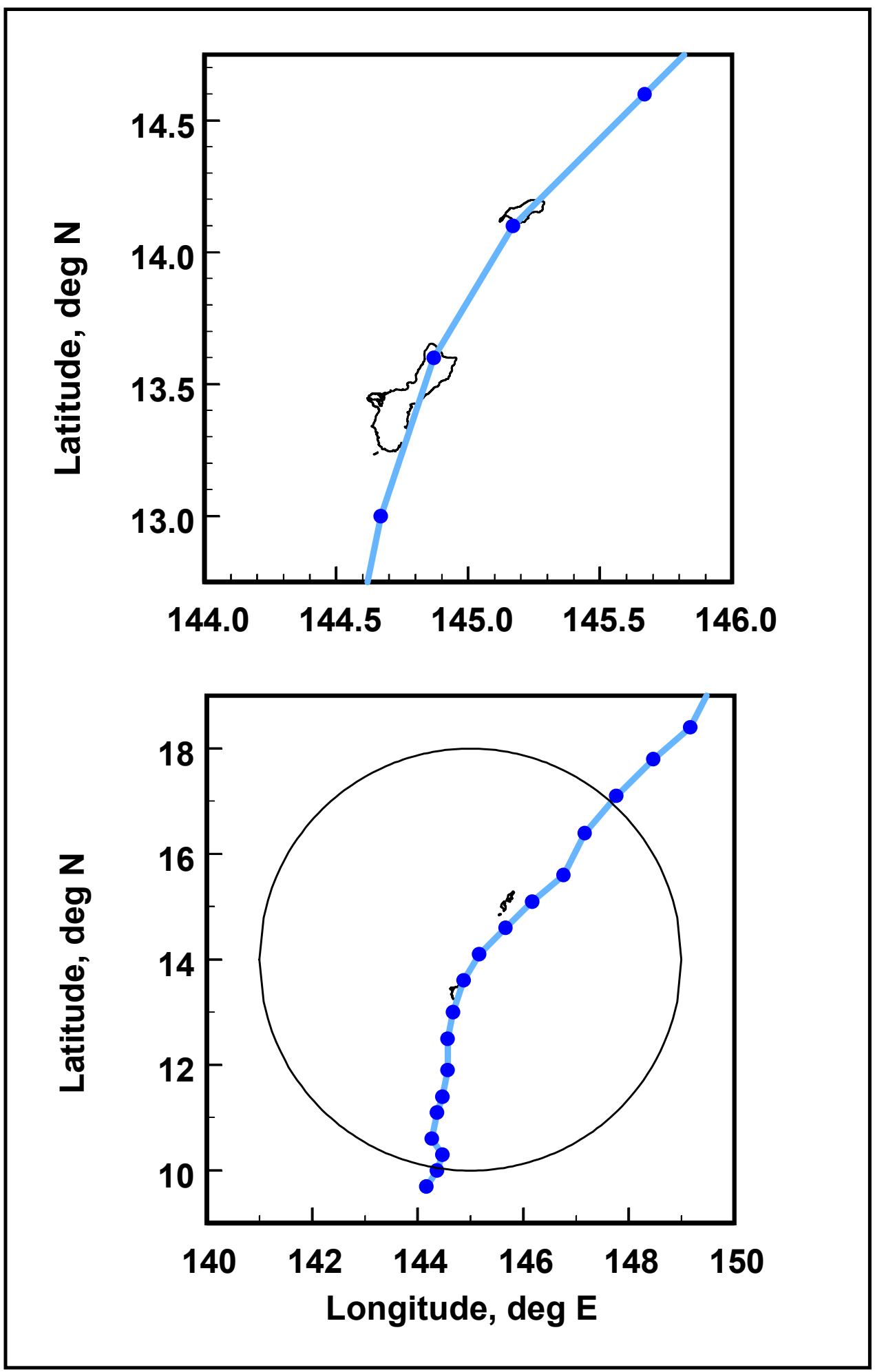

Figure A29. Storm track for hypothetical storm 5163 


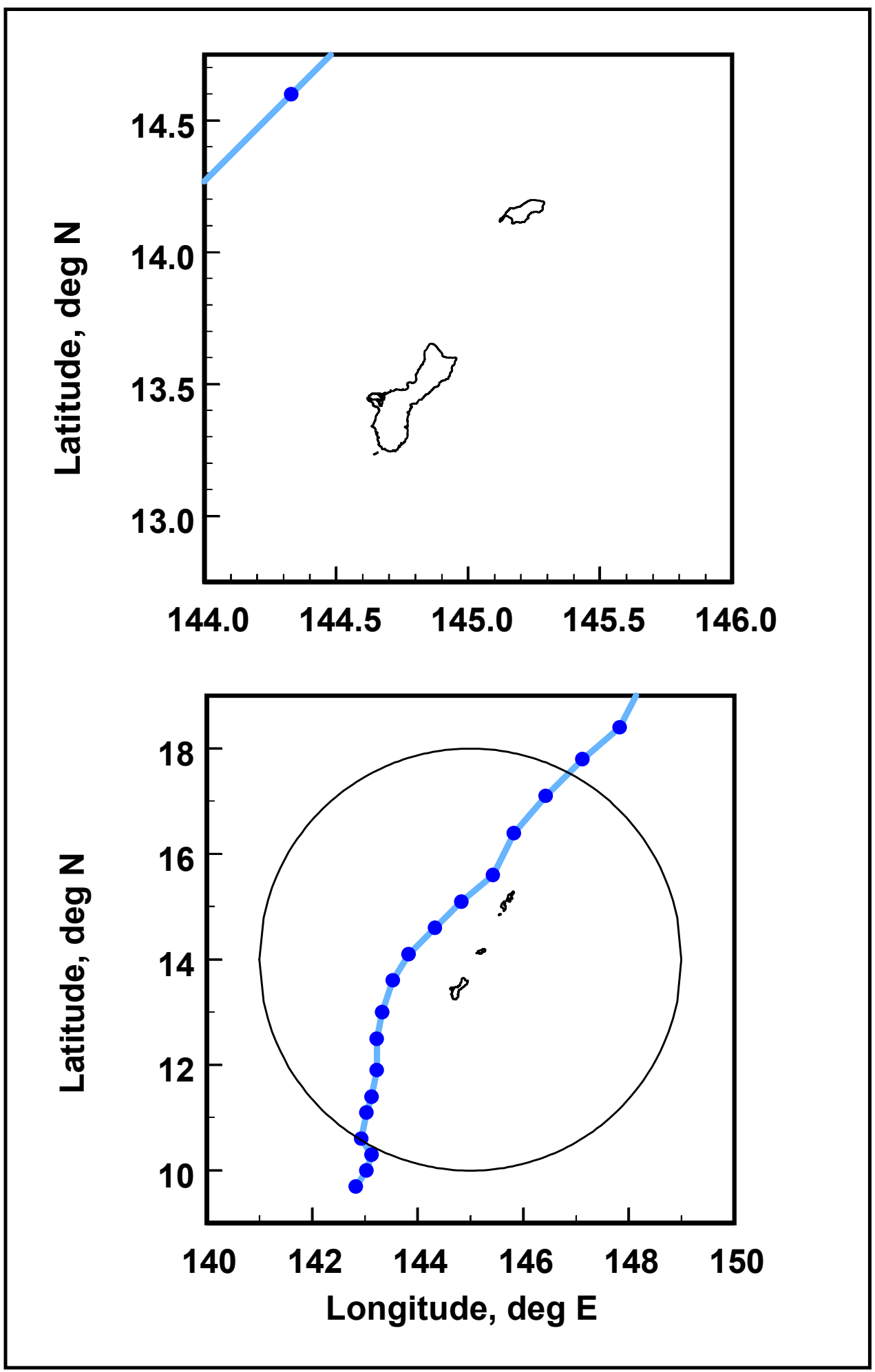

Figure A30. Storm track for hypothetical storm 6163 


\section{Appendix B Station Locations}

\begin{tabular}{|c|c|c|c|}
\hline Station & Location & Latitude, deg $N$ & Longitude, deg $\mathrm{E}$ \\
\hline 1 & Cabras Island, $\mathrm{N}$ side & 13.4642 & 144.6783 \\
\hline 2 & Cabras Island, $\mathrm{N}$ side & 13.4634 & 144.6765 \\
\hline 3 & Cabras Island, $\mathrm{N}$ side & 13.4632 & 144.6746 \\
\hline 4 & Cabras Island, $\mathrm{N}$ side & 13.4633 & 144.6726 \\
\hline 5 & Cabras Island, $\mathrm{N}$ side & 13.4635 & 144.6707 \\
\hline 6 & Cabras Island, S side & 13.4610 & 144.6784 \\
\hline 7 & Cabras Island, S side & 13.4602 & 144.6763 \\
\hline 8 & Cabras Island, S side & 13.4603 & 144.6732 \\
\hline 9 & Cabras Island, S side & 13.4604 & 144.6712 \\
\hline 10 & Cabras Island, S side & 13.4605 & 144.6685 \\
\hline 11 & Cabras Island, S side & 13.4605 & 144.6666 \\
\hline 12 & Cabras Island, S side & 13.4613 & 144.6659 \\
\hline 13 & NOS Tide Gauge & 13.4435 & 144.6566 \\
\hline
\end{tabular}




\section{Appendix C Overtopping-Frequency Relationship Tables}

This appendix contains overtopping-frequency relationship values for profiles in the proposed project area, along the north side of Cabras Island. Maximum overtopping rate and its standard deviation are given for seven return intervals for each profile. Existing profiles are given in Tables $\mathrm{C} 1-\mathrm{C} 15$ and plan profiles in Tables C16-C30. ${ }^{1}$

\footnotetext{
1 Maximum overtopping rate and overtopping rate standard deviation are in cubic feet per second in all tables in this appendix. To convert to cubic meters per second, multiply by 0.02831685 .
} 


\begin{tabular}{|c|c|c|}
\hline \multicolumn{3}{|c|}{$\begin{array}{l}\text { Table C1 } \\
\text { Return Period, Maximum Overtopping Rate, and Overtopping } \\
\text { Rate Standard Deviation for Sta } 0+00 \text {, Existing Profile }\end{array}$} \\
\hline Return Period, year & $\begin{array}{l}\text { Maximum Overtopping } \\
\text { Rate, cfs per } \mathrm{ft}\end{array}$ & $\begin{array}{l}\text { Overtopping Rate Standard } \\
\text { Deviation, cfs per } \mathrm{ft}\end{array}$ \\
\hline 2 & 0.000 & 0.000 \\
\hline 5 & 0.006 & 0.005 \\
\hline 10 & 0.101 & 0.097 \\
\hline 25 & 0.403 & 0.121 \\
\hline 50 & 0.585 & 0.132 \\
\hline 75 & 0.681 & 0.147 \\
\hline 100 & 0.729 & 0.171 \\
\hline
\end{tabular}

\begin{tabular}{|c|c|c|}
\hline \multicolumn{3}{|c|}{$\begin{array}{l}\text { Table C2 } \\
\text { Return Period, Maximum Overtopping Rate, and Overtopping } \\
\text { Rate Standard Deviation for Sta 2+00, Existing Profile }\end{array}$} \\
\hline Return Period, year & $\begin{array}{l}\text { Maximum Overtopping } \\
\text { Rate, cfs per ft }\end{array}$ & $\begin{array}{l}\text { Overtopping Rate Standard } \\
\text { Deviation, cfs per ft }\end{array}$ \\
\hline 2 & 0.000 & 0.000 \\
\hline 5 & 0.016 & 0.013 \\
\hline 10 & 0.120 & 0.072 \\
\hline 25 & 0.362 & 0.101 \\
\hline 50 & 0.525 & 0.150 \\
\hline 75 & 0.710 & 0.236 \\
\hline 100 & 0.804 & 0.315 \\
\hline
\end{tabular}

\begin{tabular}{|c|c|c|}
\hline \multicolumn{3}{|c|}{$\begin{array}{l}\text { Table C3 } \\
\text { Return Period, Maximum Overtopping Rate, and Overtopping } \\
\text { Rate Standard Deviation for Sta 4+00, Existing Profile }\end{array}$} \\
\hline Return Period, year & $\begin{array}{l}\text { Maximum Overtopping } \\
\text { Rate, cfs per ft }\end{array}$ & $\begin{array}{l}\text { Overtopping Rate Standard } \\
\text { Deviation, cfs per ft }\end{array}$ \\
\hline 2 & 0.000 & 0.000 \\
\hline 5 & 0.005 & 0.008 \\
\hline 10 & 0.128 & 0.110 \\
\hline 25 & 0.483 & 0.149 \\
\hline 50 & 0.696 & 0.157 \\
\hline 75 & 0.814 & 0.171 \\
\hline 100 & 0.873 & 0.197 \\
\hline
\end{tabular}

\begin{tabular}{|c|c|c|}
\hline \multicolumn{3}{|c|}{$\begin{array}{l}\text { Table C4 } \\
\text { Return Period, Maximum Overtopping Rate, and Overtopping } \\
\text { Rate Standard Deviation for Sta 6+00, Existing Profile }\end{array}$} \\
\hline Return Period, year & $\begin{array}{l}\text { Maximum Overtopping } \\
\text { Rate, cfs per } \mathrm{ft}\end{array}$ & $\begin{array}{l}\text { Overtopping Rate Standard } \\
\text { Deviation, cfs per } \mathrm{ft}\end{array}$ \\
\hline 2 & 0.000 & 0.000 \\
\hline 5 & 0.011 & 0.009 \\
\hline 10 & 0.041 & 0.011 \\
\hline 25 & 0.074 & 0.015 \\
\hline 50 & 0.094 & 0.017 \\
\hline 75 & 0.108 & 0.018 \\
\hline 100 & 0.115 & 0.021 \\
\hline
\end{tabular}




\begin{tabular}{|c|c|c|}
\hline \multicolumn{3}{|c|}{$\begin{array}{l}\text { Table C5 } \\
\text { Return Period, Maximum Overtopping Rate, and Overtopping } \\
\text { Rate Standard Deviation for Sta } 8+00 \text {, Existing Profile }\end{array}$} \\
\hline Return Period, year & $\begin{array}{l}\text { Maximum Overtopping } \\
\text { Rate, cfs per } \mathrm{ft}\end{array}$ & $\begin{array}{l}\text { Overtopping Rate Standard } \\
\text { Deviation, cfs per } \mathrm{ft}\end{array}$ \\
\hline 2 & 0.000 & 0.000 \\
\hline 5 & 0.017 & 0.013 \\
\hline 10 & 0.104 & 0.072 \\
\hline 25 & 0.358 & 0.113 \\
\hline 50 & 0.526 & 0.122 \\
\hline 75 & 0.614 & 0.138 \\
\hline 100 & 0.658 & 0.160 \\
\hline
\end{tabular}

\begin{tabular}{|c|c|c|}
\hline \multicolumn{3}{|c|}{$\begin{array}{l}\text { Table C6 } \\
\text { Return Period, Maximum Overtopping Rate, and Overtopping } \\
\text { Rate Standard Deviation for Sta 10+00, Existing Profile }\end{array}$} \\
\hline Return Period, year & $\begin{array}{l}\text { Maximum Overtopping } \\
\text { Rate, cfs per ft }\end{array}$ & $\begin{array}{l}\text { Overtopping Rate Standard } \\
\text { Deviation, cfs per ft }\end{array}$ \\
\hline 2 & 0.000 & 0.000 \\
\hline 5 & 0.005 & 0.007 \\
\hline 10 & 0.049 & 0.030 \\
\hline 25 & 0.145 & 0.041 \\
\hline 50 & 0.207 & 0.048 \\
\hline 75 & 0.241 & 0.052 \\
\hline 100 & 0.258 & 0.060 \\
\hline
\end{tabular}

\begin{tabular}{|c|c|c|}
\hline \multicolumn{3}{|c|}{$\begin{array}{l}\text { Table C7 } \\
\text { Return Period, Maximum Overtopping Rate, and Overtopping } \\
\text { Rate Standard Deviation for Sta 12+00, Existing Profile }\end{array}$} \\
\hline Return Period, year & $\begin{array}{l}\text { Maximum Overtopping } \\
\text { Rate, cfs per ft }\end{array}$ & $\begin{array}{l}\text { Overtopping Rate Standard } \\
\text { Deviation, cfs per } \mathrm{ft}\end{array}$ \\
\hline 2 & 0.000 & 0.000 \\
\hline 5 & 0.012 & 0.011 \\
\hline 10 & 0.107 & 0.068 \\
\hline 25 & 0.330 & 0.095 \\
\hline 50 & 0.483 & 0.133 \\
\hline 75 & 0.612 & 0.173 \\
\hline 100 & 0.677 & 0.219 \\
\hline
\end{tabular}

\begin{tabular}{|c|c|c|}
\hline \multicolumn{3}{|c|}{$\begin{array}{l}\text { Table C8 } \\
\text { Return Period, Maximum Overtopping Rate, and Overtopping } \\
\text { Rate Standard Deviation for Sta 14+00, Existing Profile }\end{array}$} \\
\hline Return Period, year & $\begin{array}{l}\text { Maximum Overtopping } \\
\text { Rate, cfs per } \mathrm{ft}\end{array}$ & $\begin{array}{l}\text { Overtopping Rate Standard } \\
\text { Deviation, cfs per } \mathrm{ft}\end{array}$ \\
\hline 2 & 0.000 & 0.000 \\
\hline 5 & 0.021 & 0.016 \\
\hline 10 & 0.130 & 0.071 \\
\hline 25 & 0.362 & 0.098 \\
\hline 50 & 0.517 & 0.132 \\
\hline 75 & 0.653 & 0.182 \\
\hline 100 & 0.722 & 0.235 \\
\hline
\end{tabular}




\begin{tabular}{|c|c|c|}
\hline \multicolumn{3}{|c|}{$\begin{array}{l}\text { Table C9 } \\
\text { Return Period, Maximum Overtopping Rate, and Overtopping } \\
\text { Rate Standard Deviation for Sta 16+00, Existing Profile }\end{array}$} \\
\hline Return Period, year & $\begin{array}{l}\text { Maximum Overtopping } \\
\text { Rate, cfs per } \mathrm{ft}\end{array}$ & $\begin{array}{l}\text { Overtopping Rate Standard } \\
\text { Deviation, cfs per } \mathrm{ft}\end{array}$ \\
\hline 2 & 0.000 & 0.000 \\
\hline 5 & 0.017 & 0.013 \\
\hline 10 & 0.121 & 0.068 \\
\hline 25 & 0.339 & 0.094 \\
\hline 50 & 0.489 & 0.135 \\
\hline 75 & 0.629 & 0.183 \\
\hline 100 & 0.700 & 0.235 \\
\hline
\end{tabular}

\begin{tabular}{|c|c|c|}
\hline \multicolumn{3}{|c|}{$\begin{array}{l}\text { Table C10 } \\
\text { Return Period, Maximum Overtopping Rate, and Overtopping } \\
\text { Rate Standard Deviation for Sta 18+00, Existing Profile }\end{array}$} \\
\hline Return Period, year & $\begin{array}{l}\text { Maximum Overtopping } \\
\text { Rate, cfs per ft }\end{array}$ & $\begin{array}{l}\text { Overtopping Rate Standard } \\
\text { Deviation, cfs per } \mathrm{ft}\end{array}$ \\
\hline 2 & 0.000 & 0.000 \\
\hline 5 & 0.013 & 0.011 \\
\hline 10 & 0.106 & 0.064 \\
\hline 25 & 0.311 & 0.090 \\
\hline 50 & 0.460 & 0.136 \\
\hline 75 & 0.599 & 0.183 \\
\hline 100 & 0.670 & 0.234 \\
\hline
\end{tabular}

\begin{tabular}{|c|c|c|}
\hline \multicolumn{3}{|c|}{$\begin{array}{l}\text { Table C11 } \\
\text { Return Period, Maximum Overtopping Rate, and Overtopping } \\
\text { Rate Standard Deviation for Sta 20+00, Existing Profile }\end{array}$} \\
\hline Return Period, year & $\begin{array}{l}\text { Maximum Overtopping } \\
\text { Rate, cfs per ft }\end{array}$ & $\begin{array}{l}\text { Overtopping Rate Standard } \\
\text { Deviation, cfs per ft }\end{array}$ \\
\hline 2 & 0.000 & 0.000 \\
\hline 5 & 0.010 & 0.009 \\
\hline 10 & 0.093 & 0.061 \\
\hline 25 & 0.286 & 0.086 \\
\hline 50 & 0.432 & 0.134 \\
\hline 75 & 0.570 & 0.182 \\
\hline 100 & 0.640 & 0.232 \\
\hline
\end{tabular}

\begin{tabular}{|c|c|c|}
\hline \multicolumn{3}{|c|}{$\begin{array}{l}\text { Table C12 } \\
\text { Return Period, Maximum Overtopping Rate, and Overtopping } \\
\text { Rate Standard Deviation for Sta 22+00, Existing Profile }\end{array}$} \\
\hline Return Period, year & $\begin{array}{l}\text { Maximum Overtopping } \\
\text { Rate, cfs per } \mathrm{ft}\end{array}$ & $\begin{array}{l}\text { Overtopping Rate Standard } \\
\text { Deviation, cfs per } \mathrm{ft}\end{array}$ \\
\hline ex & 0.000 & 0.000 \\
\hline 5 & 0.019 & 0.013 \\
\hline 10 & 0.115 & 0.061 \\
\hline 25 & 0.305 & 0.084 \\
\hline 50 & 0.444 & 0.123 \\
\hline 75 & 0.565 & 0.163 \\
\hline 100 & 0.626 & 0.209 \\
\hline
\end{tabular}




\begin{tabular}{|c|c|c|}
\hline \multicolumn{3}{|c|}{$\begin{array}{l}\text { Table C13 } \\
\text { Return Period, Maximum Overtopping Rate, and Overtopping } \\
\text { Rate Standard Deviation for Sta 24+00, Existing Profile }\end{array}$} \\
\hline Return Period, year & $\begin{array}{l}\text { Maximum Overtopping } \\
\text { Rate, cfs per } \mathrm{ft}\end{array}$ & $\begin{array}{l}\text { Overtopping Rate Standard } \\
\text { Deviation, cfs per } \mathrm{ft}\end{array}$ \\
\hline 2 & 0.000 & 0.000 \\
\hline 5 & 0.016 & 0.012 \\
\hline 10 & 0.107 & 0.060 \\
\hline 25 & 0.294 & 0.084 \\
\hline 50 & 0.434 & 0.125 \\
\hline 75 & 0.556 & 0.166 \\
\hline 100 & 0.618 & 0.212 \\
\hline
\end{tabular}

\begin{tabular}{|c|c|c|}
\hline \multicolumn{3}{|c|}{$\begin{array}{l}\text { Table C14 } \\
\text { Return Period, Maximum Overtopping Rate, and Overtopping } \\
\text { Rate Standard Deviation for Sta 26+00, Existing Profile }\end{array}$} \\
\hline Return Period, year & $\begin{array}{l}\text { Maximum Overtopping } \\
\text { Rate, cfs per ft }\end{array}$ & $\begin{array}{l}\text { Overtopping Rate Standard } \\
\text { Deviation, cfs per ft }\end{array}$ \\
\hline 2 & 0.000 & 0.000 \\
\hline 5 & 0.004 & 0.005 \\
\hline 10 & 0.058 & 0.051 \\
\hline 25 & 0.216 & 0.074 \\
\hline 50 & 0.325 & 0.091 \\
\hline 75 & 0.397 & 0.111 \\
\hline 100 & 0.434 & 0.133 \\
\hline
\end{tabular}

\begin{tabular}{|c|c|c|}
\hline \multicolumn{3}{|c|}{$\begin{array}{l}\text { Table C15 } \\
\text { Return Period, Maximum Overtopping Rate, and Overtopping } \\
\text { Rate Standard Deviation for Sta } 28+00 \text {, Existing Profile }\end{array}$} \\
\hline Return Period, year & $\begin{array}{l}\text { Maximum Overtopping } \\
\text { Rate, cfs per ft }\end{array}$ & $\begin{array}{l}\text { Overtopping Rate Standard } \\
\text { Deviation, cfs per ft }\end{array}$ \\
\hline 2 & 0.000 & 0.000 \\
\hline 5 & 0.006 & 0.005 \\
\hline 10 & 0.017 & 0.005 \\
\hline 25 & 0.028 & 0.008 \\
\hline 50 & 0.041 & 0.013 \\
\hline 75 & 0.054 & 0.018 \\
\hline 100 & 0.061 & 0.023 \\
\hline
\end{tabular}

\begin{tabular}{|c|c|c|}
\hline \multicolumn{3}{|c|}{$\begin{array}{l}\text { Table C16 } \\
\text { Return Period, Maximum Overtopping Rate, and Overtopping } \\
\text { Rate Standard Deviation for Sta 0+00, Plan Profile }\end{array}$} \\
\hline Return Period, year & $\begin{array}{l}\text { Maximum Overtopping } \\
\text { Rate, cfs per } \mathrm{ft}\end{array}$ & $\begin{array}{l}\text { Overtopping Rate Standard } \\
\text { Deviation, cfs per } \mathrm{ft}\end{array}$ \\
\hline 2 & 0.000 & 0.000 \\
\hline 5 & 0.000 & 0.001 \\
\hline 10 & 0.013 & 0.009 \\
\hline 25 & 0.043 & 0.012 \\
\hline 50 & 0.063 & 0.017 \\
\hline 75 & 0.080 & 0.023 \\
\hline 100 & 0.088 & 0.030 \\
\hline
\end{tabular}




\begin{tabular}{|c|c|c|}
\hline \multicolumn{3}{|c|}{$\begin{array}{l}\text { Table C17 } \\
\text { Return Period, Maximum Overtopping Rate, and Overtopping } \\
\text { Rate Standard Deviation for Sta } 2+00 \text {, Plan Profile }\end{array}$} \\
\hline Return Period, year & $\begin{array}{l}\text { Maximum Overtopping } \\
\text { Rate, cfs per } \mathrm{ft}\end{array}$ & $\begin{array}{l}\text { Overtopping Rate Standard } \\
\text { Deviation, cfs per } \mathrm{ft}\end{array}$ \\
\hline 2 & 0.000 & 0.000 \\
\hline 5 & 0.000 & 0.001 \\
\hline 10 & 0.012 & 0.008 \\
\hline 25 & 0.042 & 0.014 \\
\hline 50 & 0.062 & 0.019 \\
\hline 75 & 0.081 & 0.025 \\
\hline 100 & 0.091 & 0.032 \\
\hline
\end{tabular}

\begin{tabular}{|c|c|c|}
\hline \multicolumn{3}{|c|}{$\begin{array}{l}\text { Table C18 } \\
\text { Return Period, Maximum Overtopping Rate, and Overtopping } \\
\text { Rate Standard Deviation for Sta 4+00, Plan Profile }\end{array}$} \\
\hline Return Period, year & $\begin{array}{l}\text { Maximum Overtopping } \\
\text { Rate, cfs per } \mathrm{ft}\end{array}$ & $\begin{array}{l}\text { Overtopping Rate Standard } \\
\text { Deviation, cfs per } \mathrm{ft}\end{array}$ \\
\hline 2 & 0.000 & 0.000 \\
\hline 5 & 0.000 & 0.001 \\
\hline 10 & 0.012 & 0.008 \\
\hline 25 & 0.040 & 0.013 \\
\hline 50 & 0.061 & 0.019 \\
\hline 75 & 0.080 & 0.026 \\
\hline 100 & 0.090 & 0.033 \\
\hline
\end{tabular}

\begin{tabular}{|c|c|c|}
\hline \multicolumn{3}{|c|}{$\begin{array}{l}\text { Table C19 } \\
\text { Return Period, Maximum Overtopping Rate, and Overtopping } \\
\text { Rate Standard Deviation for Sta } 6+00 \text {, Plan Profile }\end{array}$} \\
\hline Return Period, year & $\begin{array}{l}\text { Maximum Overtopping } \\
\text { Rate, cfs per ft }\end{array}$ & $\begin{array}{l}\text { Overtopping Rate Standard } \\
\text { Deviation, cfs per ft }\end{array}$ \\
\hline 2 & 0.000 & 0.000 \\
\hline 5 & 0.000 & 0.001 \\
\hline 10 & 0.012 & 0.007 \\
\hline 25 & 0.038 & 0.013 \\
\hline 50 & 0.058 & 0.017 \\
\hline 75 & 0.072 & 0.020 \\
\hline 100 & 0.080 & 0.024 \\
\hline
\end{tabular}

\begin{tabular}{|c|c|c|}
\hline \multicolumn{3}{|c|}{$\begin{array}{l}\text { Table C20 } \\
\text { Return Period, Maximum Overtopping Rate, and Overtopping } \\
\text { Rate Standard Deviation for Sta } 8+00, \text { Plan Profile }\end{array}$} \\
\hline Return Period, year & $\begin{array}{l}\text { Maximum Overtopping } \\
\text { Rate, cfs per } \mathrm{ft}\end{array}$ & $\begin{array}{l}\text { Overtopping Rate Standard } \\
\text { Deviation, cfs per } \mathrm{ft}\end{array}$ \\
\hline 2 & 0.000 & 0.000 \\
\hline 5 & 0.000 & 0.000 \\
\hline 10 & 0.011 & 0.013 \\
\hline 25 & 0.053 & 0.018 \\
\hline 50 & 0.079 & 0.020 \\
\hline 75 & 0.094 & 0.023 \\
\hline 100 & 0.102 & 0.028 \\
\hline
\end{tabular}




\begin{tabular}{|c|c|c|}
\hline \multicolumn{3}{|c|}{$\begin{array}{l}\text { Table C21 } \\
\text { Return Period, Maximum Overtopping Rate, and Overtopping } \\
\text { Rate Standard Deviation for Sta } 10+00, \text { Plan Profile }\end{array}$} \\
\hline Return Period, year & $\begin{array}{l}\text { Maximum Overtopping } \\
\text { Rate, cfs per } \mathrm{ft}\end{array}$ & $\begin{array}{l}\text { Overtopping Rate Standard } \\
\text { Deviation, cfs per } \mathrm{ft}\end{array}$ \\
\hline 2 & 0.000 & 0.000 \\
\hline 5 & 0.000 & 0.000 \\
\hline 10 & 0.008 & 0.010 \\
\hline 25 & 0.039 & 0.014 \\
\hline 50 & 0.059 & 0.016 \\
\hline 75 & 0.072 & 0.019 \\
\hline 100 & 0.078 & 0.023 \\
\hline
\end{tabular}

\begin{tabular}{|c|c|c|}
\hline \multicolumn{3}{|c|}{$\begin{array}{l}\text { Table C22 } \\
\text { Return Period, Maximum Overtopping Rate, and Overtopping } \\
\text { Rate Standard Deviation for Sta 12+00, Plan Profile }\end{array}$} \\
\hline Return Period, year & $\begin{array}{l}\text { Maximum Overtopping } \\
\text { Rate, cfs per ft }\end{array}$ & $\begin{array}{l}\text { Overtopping Rate Standard } \\
\text { Deviation, cfs per ft }\end{array}$ \\
\hline 2 & 0.000 & 0.000 \\
\hline 5 & 0.000 & 0.001 \\
\hline 10 & 0.011 & 0.007 \\
\hline 25 & 0.038 & 0.017 \\
\hline 50 & 0.068 & 0.029 \\
\hline 75 & 0.104 & 0.044 \\
\hline 100 & 0.122 & 0.059 \\
\hline
\end{tabular}

\begin{tabular}{|c|c|c|}
\hline \multicolumn{3}{|c|}{$\begin{array}{l}\text { Table C23 } \\
\text { Return Period, Maximum Overtopping Rate, and Overtopping } \\
\text { Rate Standard Deviation for Sta 14+00, Plan Profile }\end{array}$} \\
\hline Return Period, year & $\begin{array}{l}\text { Maximum Overtopping } \\
\text { Rate, cfs per ft }\end{array}$ & $\begin{array}{l}\text { Overtopping Rate Standard } \\
\text { Deviation, cfs per } \mathrm{ft}\end{array}$ \\
\hline 2 & 0.000 & 0.000 \\
\hline 5 & 0.000 & 0.001 \\
\hline 10 & 0.012 & 0.009 \\
\hline 25 & 0.045 & 0.017 \\
\hline 50 & 0.075 & 0.029 \\
\hline 75 & 0.111 & 0.045 \\
\hline 100 & 0.130 & 0.060 \\
\hline
\end{tabular}

\begin{tabular}{|c|c|c|}
\hline \multicolumn{3}{|c|}{$\begin{array}{l}\text { Table C24 } \\
\text { Return Period, Maximum Overtopping Rate, and Overtopping } \\
\text { Rate Standard Deviation for Sta 16+00, Plan Profile }\end{array}$} \\
\hline Return Period, year & $\begin{array}{l}\text { Maximum Overtopping } \\
\text { Rate, cfs per } \mathrm{ft}\end{array}$ & $\begin{array}{l}\text { Overtopping Rate Standard } \\
\text { Deviation, cfs per } \mathrm{ft}\end{array}$ \\
\hline 2 & 0.000 & 0.000 \\
\hline 5 & 0.000 & 0.000 \\
\hline 10 & 0.009 & 0.007 \\
\hline 25 & 0.034 & 0.015 \\
\hline 50 & 0.061 & 0.026 \\
\hline 75 & 0.093 & 0.039 \\
\hline 100 & 0.109 & 0.052 \\
\hline
\end{tabular}




\begin{tabular}{|c|c|c|}
\hline \multicolumn{3}{|c|}{$\begin{array}{l}\text { Table C25 } \\
\text { Return Period, Maximum Overtopping Rate, and Overtopping } \\
\text { Rate Standard Deviation for Sta 18+00, Plan Profile } \\
\end{array}$} \\
\hline Return Period, year & $\begin{array}{l}\text { Maximum Overtopping } \\
\text { Rate, cfs per } \mathrm{ft}\end{array}$ & $\begin{array}{l}\text { Overtopping Rate Standard } \\
\text { Deviation, cfs per } \mathrm{ft}\end{array}$ \\
\hline 2 & 0.000 & 0.000 \\
\hline 5 & 0.000 & 0.000 \\
\hline 10 & 0.009 & 0.006 \\
\hline 25 & 0.031 & 0.015 \\
\hline 50 & 0.060 & 0.026 \\
\hline 75 & 0.091 & 0.039 \\
\hline 100 & 0.107 & 0.052 \\
\hline
\end{tabular}

\begin{tabular}{|c|c|c|}
\hline \multicolumn{3}{|c|}{$\begin{array}{l}\text { Table C26 } \\
\text { Return Period, Maximum Overtopping Rate, and Overtopping } \\
\text { Rate Standard Deviation for Sta 20+00, Plan Profile }\end{array}$} \\
\hline Return Period, year & $\begin{array}{l}\text { Maximum Overtopping } \\
\text { Rate, cfs per ft }\end{array}$ & $\begin{array}{l}\text { Overtopping Rate Standard } \\
\text { Deviation, cfs per ft }\end{array}$ \\
\hline 2 & 0.000 & 0.000 \\
\hline 5 & 0.000 & 0.000 \\
\hline 10 & 0.008 & 0.005 \\
\hline 25 & 0.026 & 0.013 \\
\hline 50 & 0.052 & 0.023 \\
\hline 75 & 0.080 & 0.035 \\
\hline 100 & 0.094 & 0.047 \\
\hline
\end{tabular}

\begin{tabular}{|c|c|c|}
\hline \multicolumn{3}{|c|}{$\begin{array}{l}\text { Table C27 } \\
\text { Return Period, Maximum Overtopping Rate, and Overtopping } \\
\text { Rate Standard Deviation for Sta 22+00, Plan Profile }\end{array}$} \\
\hline Return Period, year & $\begin{array}{l}\text { Maximum Overtopping } \\
\text { Rate, cfs per ft }\end{array}$ & $\begin{array}{l}\text { Overtopping Rate Standard } \\
\text { Deviation, cfs per ft }\end{array}$ \\
\hline 2 & 0.000 & 0.000 \\
\hline 5 & 0.000 & 0.000 \\
\hline 10 & 0.009 & 0.007 \\
\hline 25 & 0.031 & 0.017 \\
\hline 50 & 0.066 & 0.033 \\
\hline 75 & 0.105 & 0.049 \\
\hline 100 & 0.125 & 0.065 \\
\hline
\end{tabular}

\begin{tabular}{|c|c|c|}
\hline \multicolumn{3}{|c|}{$\begin{array}{l}\text { Table C28 } \\
\text { Return Period, Maximum Overtopping Rate, and Overtopping } \\
\text { Rate Standard Deviation for Sta 24+00, Plan Profile }\end{array}$} \\
\hline Return Period, year & $\begin{array}{l}\text { Maximum Overtopping } \\
\text { Rate, cfs per } \mathrm{ft}\end{array}$ & $\begin{array}{l}\text { Overtopping Rate Standard } \\
\text { Deviation, cfs per } \mathrm{ft}\end{array}$ \\
\hline 2 & 0.000 & 0.000 \\
\hline 5 & 0.000 & 0.000 \\
\hline 10 & 0.008 & 0.005 \\
\hline 25 & 0.026 & 0.012 \\
\hline 50 & 0.050 & 0.022 \\
\hline 75 & 0.075 & 0.031 \\
\hline 100 & 0.087 & 0.040 \\
\hline
\end{tabular}




\begin{tabular}{|c|c|c|}
\hline \multicolumn{3}{|c|}{$\begin{array}{l}\text { Table C29 } \\
\text { Return Period, Maximum Overtopping Rate, and Overtopping } \\
\text { Rate Standard Deviation for Sta 26+00, Plan Profile }\end{array}$} \\
\hline Return Period, year & $\begin{array}{l}\text { Maximum Overtopping } \\
\text { Rate, cfs per } \mathrm{ft}\end{array}$ & $\begin{array}{l}\text { Overtopping Rate Standard } \\
\text { Deviation, cfs per } \mathrm{ft}\end{array}$ \\
\hline 2 & 0.000 & 0.000 \\
\hline 5 & 0.000 & 0.002 \\
\hline 10 & 0.011 & 0.006 \\
\hline 25 & 0.030 & 0.010 \\
\hline 50 & 0.045 & 0.015 \\
\hline 75 & 0.058 & 0.017 \\
\hline 100 & 0.065 & 0.020 \\
\hline
\end{tabular}

\begin{tabular}{|c|c|c|}
\hline \multicolumn{3}{|c|}{$\begin{array}{l}\text { Table C30 } \\
\text { Return Period, Maximum Overtopping Rate, and Overtopping } \\
\text { Rate Standard Deviation for Sta 28+00, Plan Profile }\end{array}$} \\
\hline Return Period, year & $\begin{array}{l}\text { Maximum Overtopping } \\
\text { Rate, cfs per } \mathrm{ft}\end{array}$ & $\begin{array}{l}\text { Overtopping Rate Standard } \\
\text { Deviation, cfs per ft }\end{array}$ \\
\hline 2 & 0.000 & 0.000 \\
\hline 5 & 0.000 & 0.000 \\
\hline 10 & 0.002 & 0.005 \\
\hline 25 & 0.014 & 0.007 \\
\hline 50 & 0.023 & 0.009 \\
\hline 75 & 0.029 & 0.011 \\
\hline 100 & 0.033 & 0.014 \\
\hline
\end{tabular}




\section{Appendix D}

\section{Tables of Maximum}

\section{Overtopping Rates and Other Information by Storm}

Tables of wave parameters, storm surge, ponding level, setup, and overtopping rate that correspond to the maximum overtopping rate for each storm are provided for each existing profile. Reported wave heights and angles are the significant wave heights and approach directions seaward of the reef after application of the nearshore wave transformation model WAVTRAN. Wave angles are expressed in deg relative to shore-normal, with 90 deg being a wave approaching perpendicular to the shore. Reported wave heights correspond to peak overtopping rate at the representative profile and may not be the maximum wave heights experienced during the storm. Maximum overtopping rate for the plan profile is also included. ${ }^{1}$

\footnotetext{
1 All waves and water level components are in feet in all tables in this appendix. To convert feet to meters, multiply by 0.3048 . All maximum overtopping rates are in cubic feet per foot. To convert cubic feet to cubic meters, multiply by 0.02831685 .
} 


\begin{tabular}{|c|c|c|c|c|c|c|c|c|}
\hline \multirow[b]{2}{*}{ Storm } & \multicolumn{3}{|l|}{ Waves } & \multicolumn{3}{|c|}{ Water Level Components } & \multicolumn{2}{|c|}{$\begin{array}{l}\text { Max. Overtopping } \\
\text { Rates, cfs per ft }\end{array}$} \\
\hline & $\begin{array}{l}\text { Height } \\
\mathrm{ft}\end{array}$ & $\begin{array}{l}\text { Period } \\
\text { sec }\end{array}$ & $\begin{array}{l}\text { Angle } \\
\text { deg }\end{array}$ & $\begin{array}{l}\text { Storm } \\
\text { Surge } \\
\mathrm{ft}\end{array}$ & $\begin{array}{l}\text { Ponding } \\
\mathrm{ft}\end{array}$ & $\begin{array}{l}\text { Wave } \\
\text { Setup } \\
\mathrm{ft}\end{array}$ & $\begin{array}{l}\text { Existing } \\
\text { Profile }\end{array}$ & $\begin{array}{l}\text { Plan } \\
\text { Profile } \\
\end{array}$ \\
\hline 2348 & 16.1 & 11 & 103 & 0.4 & 2.3 & 0.8 & 0.00007 & 0.00000 \\
\hline 0150 & 12.1 & 13 & 80 & 0.1 & 2.0 & 0.7 & 0.00004 & 0.00000 \\
\hline 0853 & 23.3 & 14 & 100 & 0.6 & 3.3 & 0.9 & 0.00558 & 0.00383 \\
\hline 1953 & 11.2 & 14 & 119 & 0.2 & 1.8 & 0.7 & 0.00003 & 0.00000 \\
\hline 1557 & 17.4 & 13 & 97 & 0.5 & 2.7 & 0.8 & 0.00092 & 0.00082 \\
\hline 2057 & 40.4 & 14 & 83 & 1.4 & 4.3 & 1.2 & 0.01116 & 0.00406 \\
\hline 1861 & 16.1 & 13 & 80 & 0.2 & 2.5 & 0.8 & 0.00028 & 0.00000 \\
\hline 2762 & 40.7 & 14 & 81 & 3.1 & 3.9 & 1.3 & 0.23257 & 0.05193 \\
\hline 0163 & 21.7 & 17 & 113 & 0.8 & 3.3 & 0.9 & 0.00761 & 0.00422 \\
\hline 2563 & 25.3 & 14 & 114 & 0.3 & 3.6 & 0.9 & 0.00590 & 0.00392 \\
\hline 2965 & 12.5 & 14 & 90 & 0.0 & 2.1 & 0.7 & 0.00004 & 0.00000 \\
\hline 3367 & 31.2 & 17 & 96 & 0.5 & 4.2 & 1.0 & 0.01018 & 0.00421 \\
\hline 2168 & 12.1 & 13 & 115 & 0.3 & 1.9 & 0.7 & 0.00006 & 0.00000 \\
\hline 0571 & 17.1 & 13 & 82 & 0.3 & 2.7 & 0.8 & 0.00064 & 0.00050 \\
\hline 0676 & 36.4 & 17 & 88 & 2.9 & 3.9 & 1.3 & 0.44273 & 0.04217 \\
\hline 1977 & 20.3 & 11 & 93 & 0.9 & 2.7 & 0.9 & 0.00040 & 0.00255 \\
\hline 2379 & 14.8 & 10 & 74 & 0.4 & 2.0 & 0.8 & 0.00001 & 0.00000 \\
\hline 2187 & 17.4 & 14 & 92 & 0.1 & 2.8 & 0.8 & 0.00049 & 0.00049 \\
\hline 0188 & 32.2 & 17 & 101 & 1.0 & 4.1 & 1.0 & 0.01052 & 0.00368 \\
\hline 0289 & 19.0 & 13 & 95 & 0.5 & 2.8 & 0.8 & 0.00141 & 0.00147 \\
\hline 0190 & 17.7 & 13 & 88 & 0.3 & 2.7 & 0.8 & 0.00082 & 0.00070 \\
\hline 3190 & 32.8 & 17 & 87 & 1.0 & 4.2 & 1.0 & 0.01160 & 0.00313 \\
\hline 2691 & 14.8 & 17 & 90 & 0.0 & 2.7 & 0.7 & 0.00029 & 0.00029 \\
\hline 1592 & 33.5 & 17 & 87 & 2.1 & 4.0 & 1.2 & 0.10602 & 0.00816 \\
\hline 3192 & 18.7 & 14 & 82 & 1.0 & 2.8 & 0.9 & 0.00212 & 0.00364 \\
\hline 3594 & - & - & - & - & - & - & 0.00000 & 0.00000 \\
\hline 0597 & 44.3 & 17 & 92 & 2.1 & 4.5 & 1.3 & 0.32738 & 0.02930 \\
\hline 2997 & 24.6 & 14 & 113 & 0.3 & 3.5 & 0.9 & 0.00587 & 0.00404 \\
\hline 5163 & 36.7 & 17 & 73 & 2.8 & 4.0 & 1.3 & 0.40943 & 0.03837 \\
\hline 6163 & 18.0 & 14 & 121 & 0.6 & 2.8 & 0.8 & 0.00153 & 0.00153 \\
\hline
\end{tabular}




\begin{tabular}{|c|c|c|c|c|c|c|c|c|}
\hline \multicolumn{9}{|c|}{$\begin{array}{l}\text { Table D2 } \\
\text { Wave Parameters, Water Level Components, and Maximum } \\
\text { Overtopping Rates by Storm, Sta } 2+00\end{array}$} \\
\hline \multirow[b]{2}{*}{ Storm } & \multicolumn{3}{|l|}{ Waves } & \multicolumn{3}{|c|}{ Water Level Components } & \multicolumn{2}{|c|}{$\begin{array}{l}\text { Max. Overtopping } \\
\text { Rates, cfs per ft }\end{array}$} \\
\hline & $\begin{array}{l}\text { Height } \\
\mathrm{ft}\end{array}$ & $\begin{array}{l}\text { Period } \\
\text { sec }\end{array}$ & $\begin{array}{l}\text { Angle } \\
\text { deg }\end{array}$ & $\begin{array}{l}\text { Storm } \\
\text { Surge } \\
\text { ft }\end{array}$ & $\begin{array}{l}\text { Ponding } \\
\mathrm{ft}\end{array}$ & $\begin{array}{l}\text { Wave } \\
\text { Setup } \\
\mathrm{ft}\end{array}$ & $\begin{array}{l}\text { Existing } \\
\text { Profile }\end{array}$ & $\begin{array}{l}\text { Plan } \\
\text { Profile }\end{array}$ \\
\hline 2348 & 16.1 & 11 & 103 & 0.4 & 2.2 & 0.8 & 0.00001 & 0.00020 \\
\hline 0150 & - & - & - & - & - & - & 0.00000 & 0.00000 \\
\hline 0853 & 26.2 & 14 & 92 & 0.9 & 3.4 & 1.0 & 0.00990 & 0.00404 \\
\hline 1953 & 10.5 & 14 & 119 & 0.2 & 1.6 & 0.6 & 0.00001 & 0.00000 \\
\hline 1557 & 17.4 & 13 & 97 & 0.5 & 2.5 & 0.8 & 0.00020 & 0.00056 \\
\hline 2057 & 40.4 & 14 & 83 & 1.4 & 4.2 & 1.1 & 0.06743 & 0.00433 \\
\hline 1861 & 16.1 & 13 & 80 & 0.2 & 2.4 & 0.7 & 0.00005 & 0.00018 \\
\hline 2762 & 40.7 & 14 & 81 & 3.1 & 3.9 & 1.3 & 0.50924 & 0.05447 \\
\hline 0163 & 21.7 & 17 & 113 & 0.8 & 3.2 & 0.9 & 0.00586 & 0.00373 \\
\hline 2563 & 27.2 & 14 & 103 & 0.6 & 3.5 & 0.9 & 0.00637 & 0.00367 \\
\hline 2965 & 11.8 & 14 & 90 & 0.0 & 1.8 & 0.6 & 0.00001 & 0.00002 \\
\hline 3367 & 31.2 & 17 & 96 & 0.6 & 4.0 & 1.0 & 0.01743 & 0.00426 \\
\hline 2168 & 12.1 & 13 & 117 & 0.2 & 1.8 & 0.7 & 0.00001 & 0.00010 \\
\hline 0571 & 17.1 & 13 & 82 & 0.3 & 2.5 & 0.8 & 0.00011 & 0.00033 \\
\hline 0676 & 36.4 & 17 & 88 & 2.9 & 3.9 & 1.3 & 0.32983 & 0.04116 \\
\hline 1977 & 20.3 & 11 & 93 & 0.9 & 2.6 & 0.9 & 0.00013 & 0.00191 \\
\hline 2379 & - & - & - & - & - & - & 0.00000 & 0.00014 \\
\hline 2187 & 17.4 & 14 & 92 & 0.1 & 2.6 & 0.8 & 0.00023 & 0.00030 \\
\hline 0188 & 34.8 & 14 & 108 & 1.4 & 3.9 & 1.1 & 0.04744 & 0.00269 \\
\hline 0289 & 19.0 & 13 & 95 & 0.5 & 2.7 & 0.8 & 0.00041 & 0.00105 \\
\hline 0190 & 17.7 & 13 & 88 & 0.3 & 2.6 & 0.8 & 0.00016 & 0.00047 \\
\hline 3190 & 32.8 & 17 & 87 & 1.0 & 4.0 & 1.0 & 0.03248 & 0.00353 \\
\hline 2691 & 14.8 & 17 & 90 & 0.0 & 2.5 & 0.7 & 0.00017 & 0.00017 \\
\hline 1592 & 33.5 & 17 & 87 & 2.1 & 3.9 & 1.2 & 0.12582 & 0.00306 \\
\hline 3192 & 31.2 & 14 & 86 & 1.4 & 3.7 & 1.1 & 0.03677 & 0.00272 \\
\hline 3594 & - & - & - & - & - & - & 0.00000 & 0.00000 \\
\hline 0597 & 44.3 & 17 & 92 & 2.1 & 4.5 & 1.2 & 0.25659 & 0.02580 \\
\hline 2997 & 26.2 & 14 & 103 & 0.6 & 3.4 & 0.9 & 0.00544 & 0.00433 \\
\hline 5163 & 36.7 & 17 & 73 & 2.8 & 4.0 & 1.3 & 0.31067 & 0.03686 \\
\hline 6163 & 18.0 & 14 & 121 & 0.6 & 2.6 & 0.8 & 0.00093 & 0.00108 \\
\hline
\end{tabular}




\begin{tabular}{|c|c|c|c|c|c|c|c|c|}
\hline \multicolumn{9}{|c|}{$\begin{array}{l}\text { Table D3 } \\
\text { Wave Parameters, Water Level Components, and Maximum } \\
\text { Overtopping Rates by Storm, Sta } 4+00\end{array}$} \\
\hline \multirow[b]{2}{*}{ Storm } & \multicolumn{3}{|l|}{ Waves } & \multicolumn{3}{|c|}{ Water Level Components } & \multicolumn{2}{|c|}{$\begin{array}{l}\text { Max. Overtopping } \\
\text { Rates, cfs per ft }\end{array}$} \\
\hline & $\begin{array}{l}\text { Height } \\
\mathrm{ft}\end{array}$ & $\begin{array}{l}\text { Period } \\
\text { sec }\end{array}$ & $\begin{array}{l}\text { Angle } \\
\text { deg }\end{array}$ & $\begin{array}{l}\text { Storm } \\
\text { Surge } \\
\text { ft }\end{array}$ & $\begin{array}{l}\text { Ponding } \\
\mathrm{ft}\end{array}$ & $\begin{array}{l}\text { Wave } \\
\text { Setup } \\
\mathrm{ft}\end{array}$ & $\begin{array}{l}\text { Existing } \\
\text { Profile }\end{array}$ & $\begin{array}{l}\text { Plan } \\
\text { Profile }\end{array}$ \\
\hline 2348 & - & - & - & - & - & - & 0.00000 & 0.00000 \\
\hline 0150 & 12.1 & 13 & 80 & 0.1 & 1.6 & 0.6 & 0.00001 & 0.00000 \\
\hline 0853 & 26.2 & 14 & 92 & 0.9 & 3.2 & 0.9 & 0.00118 & 0.00426 \\
\hline 1953 & 10.5 & 14 & 119 & 0.2 & 1.4 & 0.6 & 0.00001 & 0.00000 \\
\hline 1557 & 17.4 & 13 & 97 & 0.5 & 2.3 & 0.8 & 0.00015 & 0.00037 \\
\hline 2057 & 40.4 & 14 & 83 & 1.4 & 4.1 & 1.1 & 0.01747 & 0.00338 \\
\hline 1861 & 16.1 & 13 & 80 & 0.2 & 2.2 & 0.7 & 0.00004 & 0.00000 \\
\hline 2762 & 40.7 & 14 & 81 & 3.2 & 3.9 & 1.4 & 0.34288 & 0.05510 \\
\hline 0163 & 21.7 & 17 & 113 & 0.8 & 3.1 & 0.9 & 0.00370 & 0.00433 \\
\hline 2563 & 22.0 & 14 & 119 & 0.2 & 2.9 & 0.8 & 0.00092 & 0.00413 \\
\hline 2965 & 11.8 & 14 & 90 & 0.0 & 1.7 & 0.6 & 0.00001 & 0.00000 \\
\hline 3367 & 31.2 & 17 & 96 & 0.6 & 3.8 & 1.0 & 0.01224 & 0.00404 \\
\hline 2168 & 12.1 & 13 & 117 & 0.2 & 1.6 & 0.6 & 0.00001 & 0.00000 \\
\hline 0571 & 17.1 & 13 & 82 & 0.3 & 2.3 & 0.7 & 0.00008 & 0.00021 \\
\hline 0676 & 36.4 & 17 & 88 & 2.8 & 3.9 & 1.3 & 0.51278 & 0.04037 \\
\hline 1977 & 13.1 & 13 & 84 & 0.5 & 1.8 & 0.7 & 0.00003 & 0.00142 \\
\hline 2379 & - & - & - & - & - & - & 0.00000 & 0.00000 \\
\hline 2187 & 17.4 & 14 & 92 & 0.1 & 2.5 & 0.7 & 0.00016 & 0.00018 \\
\hline 0188 & 32.2 & 17 & 101 & 1.0 & 3.9 & 1.0 & 0.02309 & 0.00422 \\
\hline 0289 & 19.0 & 13 & 95 & 0.5 & 2.5 & 0.8 & 0.00036 & 0.00074 \\
\hline 0190 & 17.7 & 13 & 88 & 0.3 & 2.4 & 0.8 & 0.00013 & 0.00031 \\
\hline 3190 & 32.8 & 17 & 87 & 1.0 & 3.9 & 1.0 & 0.02605 & 0.00374 \\
\hline 2691 & 14.8 & 17 & 90 & 0.0 & 2.3 & 0.7 & 0.00010 & 0.00010 \\
\hline 1592 & 33.5 & 17 & 87 & 2.1 & 3.8 & 1.2 & 0.12335 & 0.00464 \\
\hline 3192 & 31.2 & 14 & 86 & 1.4 & 3.5 & 1.1 & 0.00652 & 0.00407 \\
\hline 3594 & - & - & - & - & - & - & 0.00000 & 0.00000 \\
\hline 0597 & 44.3 & 17 & 92 & 2.2 & 4.4 & 1.2 & 0.36999 & 0.02289 \\
\hline 2997 & 26.2 & 14 & 103 & 0.6 & 3.3 & 0.9 & 0.00051 & 0.00419 \\
\hline 5163 & 36.7 & 17 & 73 & 2.8 & 3.9 & 1.3 & 0.48170 & 0.03561 \\
\hline 6163 & 18.0 & 14 & 121 & 0.6 & 2.5 & 0.8 & 0.00080 & 0.00076 \\
\hline
\end{tabular}




\begin{tabular}{|c|c|c|c|c|c|c|c|c|}
\hline \multicolumn{9}{|c|}{$\begin{array}{l}\text { Table D4 } \\
\text { Wave Parameters, Water Level Components, and Maximum } \\
\text { Overtopping Rates by Storm, Sta } 6+00\end{array}$} \\
\hline \multirow[b]{2}{*}{ Storm } & \multicolumn{3}{|l|}{ Waves } & \multicolumn{3}{|c|}{ Water Level Components } & \multicolumn{2}{|c|}{$\begin{array}{l}\text { Max. Overtopping } \\
\text { Rates, cfs per ft }\end{array}$} \\
\hline & $\begin{array}{l}\text { Height } \\
\mathrm{ft}\end{array}$ & $\begin{array}{l}\text { Period } \\
\text { sec }\end{array}$ & $\begin{array}{l}\text { Angle } \\
\text { deg }\end{array}$ & $\begin{array}{l}\text { Storm } \\
\text { Surge } \\
\mathrm{ft}\end{array}$ & $\begin{array}{l}\text { Ponding } \\
\mathrm{ft}\end{array}$ & $\begin{array}{l}\text { Wave } \\
\text { Setup } \\
\mathrm{ft}\end{array}$ & $\begin{array}{l}\text { Existing } \\
\text { Profile } \\
\end{array}$ & $\begin{array}{l}\text { Plan } \\
\text { Profile } \\
\end{array}$ \\
\hline 2348 & 16.1 & 11 & 103 & 0.4 & 1.9 & 0.7 & 0.00008 & 0.00008 \\
\hline 0150 & 12.1 & 13 & 80 & 0.1 & 1.5 & 0.6 & 0.00001 & 0.00001 \\
\hline 0853 & 26.2 & 14 & 92 & 0.9 & 3.1 & 0.9 & 0.00635 & 0.00406 \\
\hline 1953 & 14.4 & 10 & 100 & 0.5 & 1.5 & 0.7 & 0.00003 & 0.00003 \\
\hline 1557 & 17.4 & 13 & 97 & 0.5 & 2.2 & 0.8 & 0.00024 & 0.00024 \\
\hline 2057 & 40.4 & 14 & 83 & 1.4 & 4.0 & 1.1 & 0.05785 & 0.00412 \\
\hline 1861 & 16.1 & 13 & 80 & 0.2 & 2.0 & 0.7 & 0.00006 & 0.00006 \\
\hline 2762 & 40.7 & 14 & 81 & 3.2 & 3.9 & 1.4 & 0.05072 & 0.04412 \\
\hline 0163 & 21.7 & 17 & 113 & 0.8 & 2.9 & 0.9 & 0.00338 & 0.00338 \\
\hline 2563 & 27.2 & 14 & 103 & 0.6 & 3.2 & 0.9 & 0.00359 & 0.00359 \\
\hline 2965 & 12.5 & 14 & 90 & 0.0 & 1.6 & 0.6 & 0.00001 & 0.00001 \\
\hline 3367 & 30.8 & 14 & 103 & 0.9 & 3.4 & 1.0 & 0.01072 & 0.00302 \\
\hline 2168 & 14.4 & 11 & 116 & 0.3 & 1.6 & 0.7 & 0.00003 & 0.00003 \\
\hline 0571 & 16.7 & 13 & 80 & 0.3 & 2.1 & 0.7 & 0.00013 & 0.00013 \\
\hline 0676 & 35.8 & 14 & 87 & 1.8 & 3.7 & 1.1 & 0.06297 & 0.04059 \\
\hline 1977 & 20.3 & 11 & 93 & 0.9 & 2.3 & 0.9 & 0.00104 & 0.00104 \\
\hline 2379 & 15.4 & 10 & 81 & 0.5 & 1.7 & 0.7 & 0.00006 & 0.00006 \\
\hline 2187 & 17.4 & 14 & 92 & 0.1 & 2.3 & 0.7 & 0.00011 & 0.00011 \\
\hline 0188 & 34.8 & 14 & 108 & 1.4 & 3.7 & 1.1 & 0.03596 & 0.00429 \\
\hline 0289 & 19.0 & 13 & 95 & 0.6 & 2.4 & 0.8 & 0.00051 & 0.00051 \\
\hline 0190 & 17.7 & 13 & 88 & 0.4 & 2.2 & 0.7 & 0.00020 & 0.00020 \\
\hline 3190 & 32.8 & 17 & 87 & 1.0 & 3.8 & 1.0 & 0.02264 & 0.00434 \\
\hline 2691 & 14.8 & 17 & 90 & 0.0 & 2.2 & 0.6 & 0.00006 & 0.00006 \\
\hline 1592 & 38.7 & 14 & 93 & 1.6 & 3.9 & 1.1 & 0.06522 & 0.00339 \\
\hline 3192 & 31.2 & 14 & 86 & 1.4 & 3.4 & 1.0 & 0.02554 & 0.00385 \\
\hline 3594 & - & - & - & - & - & - & 0.00000 & 0.00000 \\
\hline 0597 & 37.1 & 17 & 85 & 1.6 & 4.0 & 1.1 & 0.06271 & 0.02197 \\
\hline 2997 & 26.2 & 14 & 103 & 0.6 & 3.1 & 0.9 & 0.00305 & 0.00305 \\
\hline 5163 & 36.7 & 17 & 73 & 2.9 & 3.9 & 1.3 & 0.03061 & 0.03567 \\
\hline 6163 & 18.0 & 14 & 121 & 0.6 & 2.3 & 0.8 & 0.00052 & 0.00052 \\
\hline
\end{tabular}




\begin{tabular}{|c|c|c|c|c|c|c|c|c|}
\hline \multicolumn{9}{|c|}{$\begin{array}{l}\text { Table D5 } \\
\text { Wave Parameters, Water Level Components, and Maximum } \\
\text { Overtopping Rates by Storm, Sta } 8+00\end{array}$} \\
\hline \multirow[b]{2}{*}{ Storm } & \multicolumn{3}{|l|}{ Waves } & \multicolumn{3}{|c|}{ Water Level Components } & \multicolumn{2}{|c|}{$\begin{array}{l}\text { Max. Overtopping } \\
\text { Rates, cfs per ft }\end{array}$} \\
\hline & $\begin{array}{l}\text { Height } \\
\mathrm{ft}\end{array}$ & $\begin{array}{l}\text { Period } \\
\text { sec }\end{array}$ & $\begin{array}{l}\text { Angle } \\
\text { deg }\end{array}$ & $\begin{array}{l}\text { Storm } \\
\text { Surge } \\
\text { ft }\end{array}$ & $\begin{array}{l}\text { Ponding } \\
\mathrm{ft}\end{array}$ & $\begin{array}{l}\text { Wave } \\
\text { Setup } \\
\mathrm{ft}\end{array}$ & $\begin{array}{l}\text { Existing } \\
\text { Profile }\end{array}$ & $\begin{array}{l}\text { Plan } \\
\text { Profile }\end{array}$ \\
\hline 2348 & 16.1 & 11 & 103 & 0.4 & 2.3 & 0.8 & 0.00031 & 0.00000 \\
\hline 0150 & 12.1 & 13 & 80 & 0.1 & 2.0 & 0.7 & 0.00004 & 0.00000 \\
\hline 0853 & 26.2 & 14 & 92 & 1.0 & 3.5 & 1.0 & 0.01316 & 0.00004 \\
\hline 1953 & 14.4 & 10 & 100 & 0.5 & 2.0 & 0.8 & 0.00014 & 0.00000 \\
\hline 1557 & 17.4 & 13 & 97 & 0.5 & 2.7 & 0.8 & 0.00082 & 0.00000 \\
\hline 2057 & 32.2 & 14 & 81 & 1.3 & 3.9 & 1.1 & 0.03933 & 0.00092 \\
\hline 1861 & 16.1 & 13 & 80 & 0.2 & 2.5 & 0.8 & 0.00028 & 0.00000 \\
\hline 2762 & 40.7 & 14 & 81 & 3.2 & 3.9 & 1.4 & 0.19135 & 0.02618 \\
\hline 0163 & 21.7 & 17 & 113 & 0.8 & 3.3 & 0.9 & 0.00761 & 0.00340 \\
\hline 2563 & 27.2 & 14 & 103 & 0.6 & 3.7 & 1.0 & 0.00877 & 0.00011 \\
\hline 2965 & 12.5 & 14 & 90 & 0.0 & 2.1 & 0.7 & 0.00004 & 0.00000 \\
\hline 3367 & 31.2 & 17 & 96 & 0.6 & 4.1 & 1.0 & 0.02235 & 0.00023 \\
\hline 2168 & 14.8 & 11 & 103 & 0.4 & 2.1 & 0.8 & 0.00016 & 0.00000 \\
\hline 0571 & 17.1 & 13 & 82 & 0.3 & 2.6 & 0.8 & 0.00053 & 0.00000 \\
\hline 0676 & 36.4 & 17 & 88 & 3.0 & 3.9 & 1.3 & 0.39028 & 0.06246 \\
\hline 1977 & 20.3 & 11 & 93 & 0.9 & 2.7 & 0.9 & 0.00255 & 0.00002 \\
\hline 2379 & 15.4 & 10 & 81 & 0.5 & 2.1 & 0.8 & 0.00022 & 0.00000 \\
\hline 2187 & 17.4 & 14 & 92 & 0.1 & 2.8 & 0.8 & 0.00049 & 0.00000 \\
\hline 0188 & 32.2 & 17 & 101 & 1.3 & 3.9 & 1.1 & 0.03933 & 0.00045 \\
\hline 0289 & 19.0 & 13 & 95 & 0.6 & 2.8 & 0.9 & 0.00156 & 0.00001 \\
\hline 0190 & 17.7 & 13 & 88 & 0.4 & 2.7 & 0.8 & 0.00075 & 0.00000 \\
\hline 3190 & 32.8 & 17 & 87 & 1.0 & 4.2 & 1.0 & 0.03906 & 0.00025 \\
\hline 2691 & 14.8 & 17 & 90 & 0.0 & 2.7 & 0.7 & 0.00029 & 0.00014 \\
\hline 1592 & 38.7 & 14 & 93 & 1.9 & 4.1 & 1.2 & 0.05683 & 0.00456 \\
\hline 3192 & 31.2 & 14 & 86 & 1.4 & 3.8 & 1.1 & 0.03804 & 0.00024 \\
\hline 3594 & - & - & - & - & - & - & 0.00000 & 0.00000 \\
\hline 0597 & 44.3 & 17 & 92 & 2.2 & 4.5 & 1.3 & 0.30779 & 0.04075 \\
\hline 2997 & 26.2 & 14 & 103 & 0.6 & 3.6 & 0.9 & 0.00759 & 0.00009 \\
\hline 5163 & 36.7 & 17 & 73 & 2.9 & 4.0 & 1.3 & 0.36373 & 0.05503 \\
\hline 6163 & 18.0 & 14 & 121 & 0.6 & 2.8 & 0.8 & 0.00153 & 0.00091 \\
\hline
\end{tabular}




\begin{tabular}{|c|c|c|c|c|c|c|c|c|}
\hline \multicolumn{9}{|c|}{$\begin{array}{l}\text { Table D6 } \\
\text { Wave Parameters, Water Level Components, and Maximum } \\
\text { Overtopping Rates by Storm, Sta } 10+00\end{array}$} \\
\hline \multirow[b]{2}{*}{ Storm } & \multicolumn{3}{|l|}{ Waves } & \multicolumn{3}{|c|}{ Water Level Components } & \multicolumn{2}{|c|}{$\begin{array}{l}\text { Max. Overtopping } \\
\text { Rates, cfs per ft }\end{array}$} \\
\hline & $\begin{array}{l}\text { Height } \\
\mathrm{ft}\end{array}$ & $\begin{array}{l}\text { Period } \\
\text { sec }\end{array}$ & $\begin{array}{l}\text { Angle } \\
\text { deg }\end{array}$ & $\begin{array}{l}\text { Storm } \\
\text { Surge } \\
\mathrm{ft}\end{array}$ & $\begin{array}{l}\text { Ponding } \\
\mathrm{ft}\end{array}$ & $\begin{array}{l}\text { Wave } \\
\text { Setup } \\
\mathrm{ft}\end{array}$ & $\begin{array}{l}\text { Existing } \\
\text { Profile }\end{array}$ & $\begin{array}{l}\text { Plan } \\
\text { Profile }\end{array}$ \\
\hline 2348 & 16.1 & 11 & 107 & 0.3 & 2.1 & 0.7 & 0.00007 & 0.00004 \\
\hline 0150 & 12.1 & 13 & 80 & 0.1 & 1.7 & 0.6 & 0.00002 & 0.00002 \\
\hline 0853 & 26.2 & 14 & 92 & 0.9 & 3.3 & 1.0 & 0.00146 & 0.00003 \\
\hline 1953 & 14.4 & 10 & 100 & 0.5 & 1.8 & 0.7 & 0.00007 & 0.00004 \\
\hline 1557 & 13.8 & 13 & 108 & 0.3 & 2.0 & 0.7 & 0.00008 & 0.00003 \\
\hline 2057 & 40.4 & 14 & 83 & 1.4 & 4.2 & 1.1 & 0.00999 & 0.00069 \\
\hline 1861 & 16.1 & 13 & 80 & 0.2 & 2.3 & 0.7 & 0.00015 & 0.00006 \\
\hline 2762 & 40.7 & 14 & 81 & 3.2 & 3.9 & 1.4 & 0.07555 & 0.01960 \\
\hline 0163 & 21.7 & 17 & 113 & 0.8 & 3.2 & 0.9 & 0.00554 & 0.00425 \\
\hline 2563 & 27.2 & 14 & 103 & 0.6 & 3.5 & 0.9 & 0.00098 & 0.00007 \\
\hline 2965 & 12.5 & 14 & 90 & 0.0 & 1.9 & 0.6 & 0.00002 & 0.00002 \\
\hline 3367 & 31.2 & 17 & 96 & 0.6 & 4.0 & 1.0 & 0.01201 & 0.00013 \\
\hline 2168 & 14.8 & 11 & 103 & 0.3 & 2.0 & 0.7 & 0.00008 & 0.00003 \\
\hline 0571 & 16.1 & 13 & 82 & 0.2 & 2.3 & 0.7 & 0.00012 & 0.00006 \\
\hline 0676 & 36.4 & 17 & 88 & 3.0 & 3.9 & 1.3 & 0.16287 & 0.04840 \\
\hline 1977 & 13.1 & 13 & 84 & 0.5 & 1.9 & 0.7 & 0.00011 & 0.00006 \\
\hline 2379 & 14.8 & 10 & 74 & 0.5 & 1.8 & 0.7 & 0.00009 & 0.00003 \\
\hline 2187 & 16.4 & 14 & 92 & 0.1 & 2.5 & 0.7 & 0.00019 & 0.00005 \\
\hline 0188 & 32.2 & 17 & 101 & 0.9 & 4.0 & 1.0 & 0.01831 & 0.00029 \\
\hline 0289 & 14.8 & 13 & 95 & 0.4 & 2.1 & 0.7 & 0.00015 & 0.00003 \\
\hline 0190 & 15.7 & 13 & 98 & 0.2 & 2.3 & 0.7 & 0.00019 & 0.00006 \\
\hline 3190 & 32.8 & 17 & 87 & 1.0 & 4.0 & 1.0 & 0.02086 & 0.00016 \\
\hline 2691 & 14.8 & 17 & 90 & 0.0 & 2.5 & 0.7 & 0.00015 & 0.00015 \\
\hline 1592 & 33.5 & 17 & 87 & 2.1 & 3.9 & 1.2 & 0.06459 & 0.00300 \\
\hline 3192 & 31.2 & 14 & 86 & 1.4 & 3.6 & 1.1 & 0.00450 & 0.00017 \\
\hline 3594 & - & - & - & - & - & - & 0.00000 & 0.00000 \\
\hline 0597 & 44.3 & 17 & 92 & 2.1 & 4.4 & 1.2 & 0.12066 & 0.02733 \\
\hline 2997 & 26.2 & 14 & 103 & 0.5 & 3.4 & 0.9 & 0.00085 & 0.00007 \\
\hline 5163 & 36.7 & 17 & 73 & 2.9 & 3.9 & 1.3 & 0.15244 & 0.04279 \\
\hline 6163 & 18.4 & 17 & 92 & 0.0 & 2.9 & 0.7 & 0.00052 & 0.00052 \\
\hline
\end{tabular}




\begin{tabular}{|c|c|c|c|c|c|c|c|c|}
\hline \multicolumn{9}{|c|}{$\begin{array}{l}\text { Table D7 } \\
\text { Wave Parameters, Water Level Components, and Maximum } \\
\text { Overtopping Rates by Storm, Sta } 12+00\end{array}$} \\
\hline \multirow[b]{2}{*}{ Storm } & \multicolumn{3}{|l|}{ Waves } & \multicolumn{3}{|c|}{ Water Level Components } & \multicolumn{2}{|c|}{$\begin{array}{l}\text { Max. Overtopping } \\
\text { Rates, cfs per ft }\end{array}$} \\
\hline & $\begin{array}{l}\text { Height } \\
\mathrm{ft}\end{array}$ & $\begin{array}{l}\text { Period } \\
\text { sec }\end{array}$ & $\begin{array}{l}\text { Angle } \\
\text { deg }\end{array}$ & $\begin{array}{l}\text { Storm } \\
\text { Surge } \\
\text { ft }\end{array}$ & $\begin{array}{l}\text { Ponding } \\
\mathrm{ft}\end{array}$ & $\begin{array}{l}\text { Wave } \\
\text { Setup } \\
\mathrm{ft}\end{array}$ & $\begin{array}{l}\text { Existing } \\
\text { Profile }\end{array}$ & $\begin{array}{l}\text { Plan } \\
\text { Profile }\end{array}$ \\
\hline 2348 & 16.1 & 11 & 107 & 0.4 & 1.9 & 0.7 & 0.00009 & 0.00009 \\
\hline 0150 & 12.1 & 13 & 80 & 0.1 & 1.5 & 0.6 & 0.00001 & 0.00001 \\
\hline 0853 & 26.2 & 14 & 92 & 0.9 & 3.2 & 0.9 & 0.00698 & 0.00419 \\
\hline 1953 & 14.4 & 10 & 100 & 0.5 & 1.6 & 0.7 & 0.00005 & 0.00003 \\
\hline 1557 & 17.4 & 13 & 97 & 0.5 & 2.3 & 0.8 & 0.00029 & 0.00029 \\
\hline 2057 & 40.4 & 14 & 83 & 1.4 & 4.0 & 1.1 & 0.06373 & 0.00429 \\
\hline 1861 & 16.1 & 13 & 80 & 0.2 & 2.1 & 0.7 & 0.00008 & 0.00008 \\
\hline 2762 & 40.7 & 14 & 81 & 3.2 & 3.9 & 1.4 & 0.39877 & 0.08164 \\
\hline 0163 & 21.7 & 17 & 113 & 0.8 & 3.0 & 0.9 & 0.00371 & 0.00371 \\
\hline 2563 & 27.2 & 14 & 103 & 0.5 & 3.3 & 0.9 & 0.00400 & 0.00400 \\
\hline 2965 & 12.5 & 14 & 90 & 0.0 & 1.7 & 0.6 & 0.00001 & 0.00001 \\
\hline 3367 & 31.2 & 17 & 96 & 0.6 & 3.8 & 0.9 & 0.01131 & 0.00333 \\
\hline 2168 & 14.8 & 11 & 103 & 0.3 & 1.8 & 0.7 & 0.00004 & 0.00004 \\
\hline 0571 & 16.7 & 13 & 80 & 0.3 & 2.2 & 0.7 & 0.00017 & 0.00017 \\
\hline 0676 & 36.4 & 17 & 88 & 3.0 & 3.9 & 1.3 & 0.32837 & 0.03822 \\
\hline 1977 & 20.3 & 11 & 93 & 0.9 & 2.4 & 0.9 & 0.00159 & 0.00121 \\
\hline 2379 & 15.4 & 10 & 81 & 0.5 & 1.7 & 0.7 & 0.00008 & 0.00000 \\
\hline 2187 & 17.4 & 14 & 92 & 0.1 & 2.4 & 0.7 & 0.00014 & 0.00014 \\
\hline 0188 & 34.8 & 14 & 108 & 1.4 & 3.7 & 1.1 & 0.03573 & 0.00429 \\
\hline 0289 & 19.0 & 13 & 95 & 0.5 & 2.4 & 0.8 & 0.00060 & 0.00060 \\
\hline 0190 & 17.7 & 13 & 88 & 0.3 & 2.3 & 0.8 & 0.00024 & 0.00024 \\
\hline 3190 & 32.8 & 17 & 87 & 1.0 & 3.8 & 1.0 & 0.02559 & 0.00325 \\
\hline 2691 & 14.8 & 17 & 90 & 0.0 & 2.2 & 0.7 & 0.00008 & 0.00008 \\
\hline 1592 & 33.5 & 17 & 87 & 2.1 & 3.8 & 1.2 & 0.11372 & 0.00378 \\
\hline 3192 & 31.2 & 14 & 86 & 1.4 & 3.5 & 1.1 & 0.02767 & 0.00427 \\
\hline 3594 & - & - & - & - & - & - & 0.00000 & 0.00000 \\
\hline 0597 & 44.3 & 17 & 92 & 2.1 & 4.4 & 1.2 & 0.21838 & 0.00985 \\
\hline 2997 & 26.2 & 14 & 103 & 0.5 & 3.2 & 0.9 & 0.00327 & 0.00327 \\
\hline 5163 & 36.7 & 17 & 73 & 2.9 & 3.9 & 1.3 & 0.30460 & 0.03031 \\
\hline 6163 & 18.0 & 14 & 121 & 0.6 & 2.4 & 0.8 & 0.00059 & 0.00059 \\
\hline
\end{tabular}




\begin{tabular}{|c|c|c|c|c|c|c|c|c|}
\hline \multicolumn{9}{|c|}{$\begin{array}{l}\text { Table D8 } \\
\text { Wave Parameters, Water Level Components, and Maximum } \\
\text { Overtopping Rates by Storm, Sta } 14+00\end{array}$} \\
\hline \multirow[b]{2}{*}{ Storm } & \multicolumn{3}{|l|}{ Waves } & \multicolumn{3}{|c|}{ Water Level Components } & \multicolumn{2}{|c|}{$\begin{array}{l}\text { Max. Overtopping } \\
\text { Rates, cfs per ft }\end{array}$} \\
\hline & $\begin{array}{l}\text { Height } \\
\mathrm{ft}\end{array}$ & $\begin{array}{l}\text { Period } \\
\text { sec }\end{array}$ & $\begin{array}{l}\text { Angle } \\
\text { deg }\end{array}$ & $\begin{array}{l}\text { Storm } \\
\text { Surge } \\
\mathrm{ft}\end{array}$ & $\begin{array}{l}\text { Ponding } \\
\mathrm{ft}\end{array}$ & $\begin{array}{l}\text { Wave } \\
\text { Setup } \\
\mathrm{ft}\end{array}$ & $\begin{array}{l}\text { Existing } \\
\text { Profile }\end{array}$ & $\begin{array}{l}\text { Plan } \\
\text { Profile }\end{array}$ \\
\hline 2348 & 16.1 & 11 & 107 & 0.4 & 2.3 & 0.8 & 0.00029 & 0.00029 \\
\hline 0150 & 12.1 & 13 & 80 & 0.1 & 2.0 & 0.7 & 0.00004 & 0.00004 \\
\hline 0853 & 26.2 & 14 & 92 & 0.9 & 3.5 & 1.0 & 0.01259 & 0.00383 \\
\hline 1953 & 14.4 & 10 & 100 & 0.5 & 2.0 & 0.8 & 0.00013 & 0.00013 \\
\hline 1557 & 17.4 & 13 & 97 & 0.5 & 2.7 & 0.8 & 0.00082 & 0.00082 \\
\hline 2057 & 40.4 & 14 & 83 & 1.4 & 4.3 & 1.2 & 0.09113 & 0.00428 \\
\hline 1861 & 16.1 & 13 & 80 & 0.2 & 2.5 & 0.8 & 0.00031 & 0.00031 \\
\hline 2762 & 40.7 & 14 & 81 & 3.2 & 3.9 & 1.4 & 0.43611 & 0.08521 \\
\hline 0163 & 21.7 & 17 & 113 & 0.8 & 3.3 & 0.9 & 0.00725 & 0.00422 \\
\hline 2563 & 27.2 & 14 & 103 & 0.5 & 3.7 & 1.0 & 0.00837 & 0.00372 \\
\hline 2965 & 12.5 & 14 & 90 & 0.0 & 2.1 & 0.7 & 0.00004 & 0.00004 \\
\hline 3367 & 31.2 & 17 & 96 & 0.6 & 4.1 & 1.0 & 0.02146 & 0.00421 \\
\hline 2168 & 14.8 & 11 & 103 & 0.3 & 2.2 & 0.7 & 0.00015 & 0.00015 \\
\hline 0571 & 17.1 & 13 & 82 & 0.3 & 2.6 & 0.8 & 0.00053 & 0.00053 \\
\hline 0676 & 36.4 & 17 & 88 & 3.0 & 3.9 & 1.3 & 0.34515 & 0.04398 \\
\hline 1977 & 20.3 & 11 & 93 & 0.9 & 2.7 & 0.9 & 0.00255 & 0.00255 \\
\hline 2379 & 15.4 & 10 & 81 & 0.5 & 2.1 & 0.8 & 0.00022 & 0.00022 \\
\hline 2187 & 17.4 & 14 & 92 & 0.1 & 2.8 & 0.8 & 0.00049 & 0.00049 \\
\hline 0188 & 34.8 & 14 & 108 & 1.3 & 4.0 & 1.1 & 0.05188 & 0.00349 \\
\hline 0289 & 19.0 & 13 & 95 & 0.5 & 2.8 & 0.8 & 0.00147 & 0.00147 \\
\hline 0190 & 17.7 & 13 & 88 & 0.3 & 2.7 & 0.8 & 0.00070 & 0.00070 \\
\hline 3190 & 32.8 & 17 & 87 & 1.0 & 4.2 & 1.0 & 0.04208 & 0.00313 \\
\hline 2691 & 14.8 & 17 & 90 & 0.0 & 2.7 & 0.7 & 0.00029 & 0.00029 \\
\hline 1592 & 33.5 & 17 & 87 & 2.1 & 3.9 & 1.2 & 0.13957 & 0.00417 \\
\hline 3192 & 31.2 & 14 & 86 & 1.4 & 3.8 & 1.1 & 0.04146 & 0.00364 \\
\hline 3594 & - & - & - & - & - & - & 0.00000 & 0.00000 \\
\hline 0597 & 44.3 & 17 & 92 & 2.1 & 4.6 & 1.2 & 0.25912 & 0.01771 \\
\hline 2997 & 26.2 & 14 & 103 & 0.5 & 3.6 & 0.9 & 0.00689 & 0.00421 \\
\hline 5163 & 36.7 & 17 & 73 & 2.9 & 4.0 & 1.3 & 0.32526 & 0.03677 \\
\hline 6163 & 18.0 & 14 & 121 & 0.6 & 2.8 & 0.8 & 0.00144 & 0.00144 \\
\hline
\end{tabular}




\begin{tabular}{|c|c|c|c|c|c|c|c|c|}
\hline \multicolumn{9}{|c|}{$\begin{array}{l}\text { Table D9 } \\
\text { Wave Parameters, Water Level Components, and Maximum } \\
\text { Overtopping Rates by Storm, Sta } 16+00\end{array}$} \\
\hline \multirow[b]{2}{*}{ Storm } & \multicolumn{3}{|l|}{ Waves } & \multicolumn{3}{|c|}{ Water Level Components } & \multicolumn{2}{|c|}{$\begin{array}{l}\text { Max. Overtopping } \\
\text { Rates, cfs per ft }\end{array}$} \\
\hline & $\begin{array}{l}\text { Height } \\
\mathrm{ft}\end{array}$ & $\begin{array}{l}\text { Period } \\
\text { sec }\end{array}$ & $\begin{array}{l}\text { Angle } \\
\text { deg }\end{array}$ & $\begin{array}{l}\text { Storm } \\
\text { Surge } \\
\text { ft }\end{array}$ & $\begin{array}{l}\text { Ponding } \\
\mathrm{ft}\end{array}$ & $\begin{array}{l}\text { Wave } \\
\text { Setup } \\
\mathrm{ft}\end{array}$ & $\begin{array}{l}\text { Existing } \\
\text { Profile }\end{array}$ & $\begin{array}{l}\text { Plan } \\
\text { Profile }\end{array}$ \\
\hline 2348 & 16.1 & 11 & 103 & 0.4 & 2.2 & 0.8 & 0.00021 & 0.00021 \\
\hline 0150 & 11.9 & 13 & 80 & 0.1 & 1.8 & 0.7 & 0.00002 & 0.00002 \\
\hline 0853 & 26.2 & 14 & 92 & 0.9 & 3.4 & 1.0 & 0.01044 & 0.00420 \\
\hline 1953 & 14.2 & 11 & 103 & 0.4 & 2.0 & 0.7 & 0.00009 & 0.00009 \\
\hline 1557 & 17.4 & 13 & 97 & 0.5 & 2.5 & 0.8 & 0.00063 & 0.00063 \\
\hline 2057 & 40.1 & 14 & 83 & 1.4 & 4.2 & 1.2 & 0.07889 & 0.00419 \\
\hline 1861 & 15.8 & 13 & 80 & 0.2 & 2.4 & 0.7 & 0.00020 & 0.00020 \\
\hline 2762 & 40.3 & 14 & 81 & 3.2 & 3.9 & 1.4 & 0.42443 & 0.07245 \\
\hline 0163 & 22.3 & 17 & 113 & 0.8 & 3.3 & 0.9 & 0.00662 & 0.00401 \\
\hline 2563 & 27.3 & 14 & 103 & 0.5 & 3.6 & 0.9 & 0.00683 & 0.00403 \\
\hline 2965 & 12.4 & 14 & 90 & 0.0 & 2.0 & 0.6 & 0.00003 & 0.00003 \\
\hline 3367 & 31.2 & 17 & 96 & 0.6 & 4.0 & 1.0 & 0.01784 & 0.00391 \\
\hline 2168 & 14.9 & 11 & 103 & 0.3 & 2.1 & 0.7 & 0.00011 & 0.00011 \\
\hline 0571 & 16.8 & 13 & 82 & 0.3 & 2.5 & 0.8 & 0.00035 & 0.00035 \\
\hline 0676 & 36.2 & 17 & 88 & 3.0 & 3.9 & 1.3 & 0.33460 & 0.03637 \\
\hline 1977 & 20.3 & 11 & 93 & 0.9 & 2.6 & 0.9 & 0.00202 & 0.00202 \\
\hline 2379 & 15.3 & 10 & 81 & 0.5 & 2.0 & 0.8 & 0.00015 & 0.00015 \\
\hline 2187 & 17.3 & 14 & 92 & 0.1 & 2.7 & 0.8 & 0.00034 & 0.00034 \\
\hline 0188 & 35.0 & 14 & 108 & 1.3 & 3.9 & 1.1 & 0.04634 & 0.00268 \\
\hline 0289 & 19.1 & 13 & 95 & 0.5 & 2.7 & 0.8 & 0.00116 & 0.00116 \\
\hline 0190 & 17.6 & 13 & 88 & 0.3 & 2.6 & 0.8 & 0.00050 & 0.00050 \\
\hline 3190 & 32.6 & 17 & 87 & 1.0 & 4.1 & 1.0 & 0.03550 & 0.00383 \\
\hline 2691 & 14.7 & 17 & 90 & 0.0 & 2.5 & 0.7 & 0.00019 & 0.00019 \\
\hline 1592 & 33.2 & 17 & 87 & 2.1 & 3.9 & 1.2 & 0.12840 & 0.00323 \\
\hline 3192 & 31.0 & 14 & 86 & 1.4 & 3.7 & 1.1 & 0.03605 & 0.00281 \\
\hline 3594 & - & - & - & - & - & - & 0.00000 & 0.00000 \\
\hline 0597 & 44.2 & 17 & 92 & 2.1 & 4.5 & 1.2 & 0.23873 & 0.01201 \\
\hline 2997 & 26.4 & 14 & 103 & 0.5 & 3.5 & 0.9 & 0.00559 & 0.00413 \\
\hline 5163 & 36.0 & 17 & 73 & 2.8 & 3.9 & 1.3 & 0.30145 & 0.02627 \\
\hline 6163 & 18.6 & 14 & 121 & 0.6 & 2.7 & 0.8 & 0.00128 & 0.00128 \\
\hline
\end{tabular}




\begin{tabular}{|c|c|c|c|c|c|c|c|c|}
\hline \multicolumn{9}{|c|}{$\begin{array}{l}\text { Table D10 } \\
\text { Wave Parameters, Water Level Components, and Maximum } \\
\text { Overtopping Rates by Storm, Sta } 18+00\end{array}$} \\
\hline \multirow[b]{2}{*}{ Storm } & \multicolumn{3}{|l|}{ Waves } & \multicolumn{3}{|c|}{ Water Level Components } & \multicolumn{2}{|c|}{$\begin{array}{l}\text { Max. Overtopping } \\
\text { Rates, cfs per ft }\end{array}$} \\
\hline & $\begin{array}{l}\text { Height } \\
\mathrm{ft}\end{array}$ & $\begin{array}{l}\text { Period } \\
\text { sec }\end{array}$ & $\begin{array}{l}\text { Angle } \\
\text { deg }\end{array}$ & $\begin{array}{l}\text { Storm } \\
\text { Surge } \\
\text { ft }\end{array}$ & $\begin{array}{l}\text { Ponding } \\
\mathrm{ft}\end{array}$ & $\begin{array}{l}\text { Wave } \\
\text { Setup } \\
\text { ft }\end{array}$ & $\begin{array}{l}\text { Existing } \\
\text { Profile }\end{array}$ & $\begin{array}{l}\text { Plan } \\
\text { Profile }\end{array}$ \\
\hline 2348 & 16.2 & 11 & 103 & 0.4 & 2.1 & 0.7 & 0.00014 & 0.00014 \\
\hline 0150 & 11.6 & 13 & 80 & 0.1 & 1.6 & 0.6 & 0.00001 & 0.00001 \\
\hline 0853 & 26.1 & 14 & 92 & 0.9 & 3.3 & 0.9 & 0.00789 & 0.00392 \\
\hline 1953 & 14.4 & 11 & 103 & 0.3 & 1.8 & 0.7 & 0.00005 & 0.00005 \\
\hline 1557 & 17.5 & 13 & 97 & 0.5 & 2.4 & 0.8 & 0.00063 & 0.00043 \\
\hline 2057 & 39.6 & 14 & 83 & 1.4 & 4.1 & 1.1 & 0.06368 & 0.00329 \\
\hline 1861 & 15.5 & 13 & 80 & 0.2 & 2.2 & 0.7 & 0.00010 & 0.00010 \\
\hline 2762 & 39.8 & 14 & 81 & 3.2 & 3.8 & 1.4 & 0.40801 & 0.07179 \\
\hline 0163 & 23.2 & 17 & 113 & 0.8 & 3.2 & 0.9 & 0.00579 & 0.00336 \\
\hline 2563 & 27.5 & 14 & 103 & 0.5 & 3.4 & 0.9 & 0.00504 & 0.00425 \\
\hline 2965 & 11.7 & 14 & 90 & 0.0 & 1.7 & 0.6 & 0.00001 & 0.00001 \\
\hline 3367 & 31.3 & 17 & 96 & 0.6 & 3.9 & 1.0 & 0.01354 & 0.00417 \\
\hline 2168 & 15.1 & 11 & 103 & 0.3 & 1.9 & 0.7 & 0.00007 & 0.00007 \\
\hline 0571 & 16.5 & 13 & 82 & 0.3 & 2.3 & 0.7 & 0.00019 & 0.00019 \\
\hline 0676 & 36.0 & 17 & 88 & 2.9 & 3.9 & 1.3 & 0.31984 & 0.03544 \\
\hline 1977 & 20.2 & 11 & 93 & 0.9 & 2.5 & 0.9 & 0.00143 & 0.00143 \\
\hline 2379 & 15.1 & 10 & 81 & 0.5 & 1.8 & 0.7 & 0.00009 & 0.00009 \\
\hline 2187 & 17.2 & 14 & 92 & 0.1 & 2.5 & 0.7 & 0.00020 & 0.00020 \\
\hline 0188 & 35.4 & 14 & 108 & 1.3 & 3.8 & 1.1 & 0.03982 & 0.00388 \\
\hline 0289 & 19.2 & 13 & 95 & 0.5 & 2.6 & 0.8 & 0.00081 & 0.00081 \\
\hline 0190 & 17.4 & 13 & 88 & 0.3 & 2.4 & 0.8 & 0.00030 & 0.00030 \\
\hline 3190 & 32.2 & 17 & 87 & 1.0 & 3.9 & 1.0 & 0.02754 & 0.00381 \\
\hline 2691 & 14.6 & 17 & 90 & 0.0 & 2.4 & 0.7 & 0.00011 & 0.00011 \\
\hline 1592 & 30.7 & 14 & 86 & 2.1 & 3.8 & 1.2 & 0.11360 & 0.00414 \\
\hline 3192 & 30.7 & 14 & 86 & 1.4 & 3.5 & 1.1 & 0.02930 & 0.00390 \\
\hline 3594 & - & - & - & - & - & - & 0.00000 & 0.00000 \\
\hline 0597 & 44.0 & 17 & 92 & 2.0 & 4.4 & 1.2 & 0.21164 & 0.00890 \\
\hline 2997 & 26.5 & 14 & 103 & 0.5 & 3.3 & 0.9 & 0.00408 & 0.00408 \\
\hline 5163 & 35.0 & 17 & 73 & 2.8 & 3.8 & 1.3 & 0.26961 & 0.02061 \\
\hline 6163 & 19.3 & 14 & 121 & 0.6 & 2.7 & 0.8 & 0.00108 & 0.00108 \\
\hline
\end{tabular}




\begin{tabular}{|c|c|c|c|c|c|c|c|c|}
\hline \multirow{2}{*}{ Storm } & \multicolumn{3}{|l|}{ Waves } & \multicolumn{3}{|c|}{ Water Level Components } & \multicolumn{2}{|c|}{$\begin{array}{l}\text { Max. Overtopping } \\
\text { Rates, cfs per ft }\end{array}$} \\
\hline & $\begin{array}{l}\text { Height } \\
\mathrm{ft}\end{array}$ & $\begin{array}{l}\text { Period } \\
\text { sec }\end{array}$ & $\begin{array}{l}\text { Angle } \\
\text { deg }\end{array}$ & $\begin{array}{l}\text { Storm } \\
\text { Surge } \\
\mathrm{ft}\end{array}$ & $\begin{array}{l}\text { Ponding } \\
\mathrm{ft}\end{array}$ & $\begin{array}{l}\text { Wave } \\
\text { Setup } \\
\mathrm{ft}\end{array}$ & $\begin{array}{l}\text { Existing } \\
\text { Profile } \\
\end{array}$ & $\begin{array}{l}\text { Plan } \\
\text { Profile } \\
\end{array}$ \\
\hline 2348 & 16.3 & 11 & 103 & 0.4 & 1.9 & 0.7 & 0.00008 & 0.00008 \\
\hline 0150 & - & - & - & - & - & - & 0.00000 & 0.00000 \\
\hline 0853 & 26.0 & 14 & 92 & 0.9 & 3.1 & 0.9 & 0.00584 & 0.00431 \\
\hline 1953 & 14.6 & 11 & 103 & 0.3 & 1.7 & 0.7 & 0.00003 & 0.00003 \\
\hline 1557 & 17.6 & 13 & 97 & 0.5 & 2.2 & 0.8 & 0.00028 & 0.00028 \\
\hline 2057 & 39.2 & 14 & 83 & 1.4 & 3.9 & 1.1 & 0.05059 & 0.00416 \\
\hline 1861 & 15.1 & 13 & 80 & 0.2 & 1.9 & 0.7 & 0.00004 & 0.00004 \\
\hline 2762 & 39.3 & 14 & 81 & 3.2 & 3.8 & 1.3 & 0.39151 & 0.06394 \\
\hline 0163 & 24.2 & 17 & 113 & 0.8 & 3.2 & 0.9 & 0.00503 & 0.00226 \\
\hline 2563 & 27.5 & 14 & 103 & 0.5 & 3.3 & 0.9 & 0.00363 & 0.00363 \\
\hline 2965 & 12.2 & 14 & 90 & 0.0 & 1.6 & 0.6 & 0.00001 & 0.00001 \\
\hline 3367 & 31.6 & 14 & 113 & 0.8 & 3.5 & 1.0 & 0.01059 & 0.00403 \\
\hline 2168 & 15.4 & 11 & 116 & 0.3 & 1.8 & 0.7 & 0.00004 & 0.00004 \\
\hline 0571 & 15.8 & 13 & 80 & 0.3 & 2.0 & 0.7 & 0.00009 & 0.00009 \\
\hline 0676 & 35.7 & 17 & 88 & 2.9 & 3.8 & 1.3 & 0.30508 & 0.03052 \\
\hline 1977 & 20.1 & 11 & 93 & 0.9 & 2.3 & 0.8 & 0.00098 & 0.00098 \\
\hline 2379 & 15.0 & 10 & 81 & 0.5 & 1.6 & 0.7 & 0.00005 & 0.00005 \\
\hline 2187 & 17.2 & 14 & 92 & 0.1 & 2.3 & 0.7 & 0.00011 & 0.00011 \\
\hline 0188 & 35.7 & 14 & 108 & 1.3 & 3.7 & 1.1 & 0.03390 & 0.00410 \\
\hline 0289 & 19.3 & 13 & 95 & 0.5 & 2.4 & 0.8 & 0.00055 & 0.00055 \\
\hline 0190 & 17.3 & 13 & 88 & 0.3 & 2.2 & 0.7 & 0.00017 & 0.00017 \\
\hline 3190 & 31.9 & 17 & 87 & 1.0 & 3.7 & 1.0 & 0.02095 & 0.00414 \\
\hline 2691 & 14.5 & 17 & 90 & 0.0 & 2.1 & 0.6 & 0.00006 & 0.00006 \\
\hline 1592 & 32.5 & 17 & 87 & 2.1 & 3.7 & 1.1 & 0.09976 & 0.00323 \\
\hline 3192 & 30.5 & 14 & 86 & 1.4 & 3.4 & 1.0 & 0.02346 & 0.00425 \\
\hline 3594 & - & - & - & - & - & - & 0.00000 & 0.00000 \\
\hline 0597 & 44.0 & 17 & 99 & 2.0 & 4.3 & 1.2 & 0.18806 & 0.00566 \\
\hline 2997 & 27.2 & 14 & 107 & 0.4 & 3.2 & 0.9 & 0.00293 & 0.00293 \\
\hline 5163 & 34.0 & 17 & 73 & 2.8 & 3.7 & 1.2 & 0.23955 & 0.01374 \\
\hline 6163 & 20.1 & 14 & 121 & 0.6 & 2.6 & 0.8 & 0.00090 & 0.00090 \\
\hline
\end{tabular}




\begin{tabular}{|c|c|c|c|c|c|c|c|c|}
\hline \multicolumn{9}{|c|}{$\begin{array}{l}\text { Table D12 } \\
\text { Wave Parameters, Water Level Components, and Maximum } \\
\text { Overtopping Rates by Storm, Sta } 22+00\end{array}$} \\
\hline \multirow[b]{2}{*}{ Storm } & \multicolumn{3}{|l|}{ Waves } & \multicolumn{3}{|c|}{ Water Level Components } & \multicolumn{2}{|c|}{$\begin{array}{l}\text { Max. Overtopping } \\
\text { Rates, cfs per ft }\end{array}$} \\
\hline & $\begin{array}{l}\text { Height } \\
\mathrm{ft}\end{array}$ & $\begin{array}{l}\text { Period } \\
\text { sec }\end{array}$ & $\begin{array}{l}\text { Angle } \\
\text { deg }\end{array}$ & $\begin{array}{l}\text { Storm } \\
\text { Surge } \\
\text { ft }\end{array}$ & $\begin{array}{l}\text { Ponding } \\
\mathrm{ft}\end{array}$ & $\begin{array}{l}\text { Wave } \\
\text { Setup } \\
\text { ft }\end{array}$ & $\begin{array}{l}\text { Existing } \\
\text { Profile }\end{array}$ & $\begin{array}{l}\text { Plan } \\
\text { Profile }\end{array}$ \\
\hline 2348 & 16.4 & 11 & 92 & 0.4 & 2.4 & 0.8 & 0.00032 & 0.00032 \\
\hline 0150 & 10.8 & 13 & 73 & 0.1 & 1.7 & 0.6 & 0.00002 & 0.00002 \\
\hline 0853 & 25.9 & 14 & 82 & 0.9 & 3.5 & 1.0 & 0.01149 & 0.00316 \\
\hline 1953 & 14.8 & 11 & 92 & 0.3 & 2.2 & 0.7 & 0.00015 & 0.00015 \\
\hline 1557 & 17.7 & 13 & 88 & 0.5 & 2.7 & 0.8 & 0.00090 & 0.00090 \\
\hline 2057 & 38.7 & 14 & 71 & 1.4 & 4.2 & 1.1 & 0.07345 & 0.00434 \\
\hline 1861 & 14.8 & 13 & 72 & 0.2 & 2.4 & 0.7 & 0.00017 & 0.00017 \\
\hline 2762 & 38.7 & 14 & 69 & 3.2 & 3.8 & 1.3 & 0.38320 & 0.08573 \\
\hline 0163 & 25.3 & 17 & 107 & 0.8 & 3.7 & 0.9 & 0.01254 & 0.00301 \\
\hline 2563 & 27.9 & 14 & 92 & 0.5 & 3.7 & 1.0 & 0.00877 & 0.00417 \\
\hline 2965 & 12.1 & 14 & 83 & 0.0 & 2.1 & 0.7 & 0.00003 & 0.00003 \\
\hline 3367 & 32.2 & 14 & 102 & 0.8 & 4.0 & 1.0 & 0.02187 & 0.00421 \\
\hline 2168 & 15.7 & 11 & 106 & 0.3 & 2.3 & 0.8 & 0.00020 & 0.00020 \\
\hline 0571 & 15.7 & 13 & 74 & 0.3 & 2.5 & 0.8 & 0.00031 & 0.00031 \\
\hline 0676 & 35.4 & 17 & 79 & 2.9 & 3.9 & 1.3 & 0.31667 & 0.03670 \\
\hline 1977 & 20.0 & 11 & 80 & 0.9 & 2.7 & 0.9 & 0.00224 & 0.00224 \\
\hline 2379 & 14.8 & 10 & 68 & 0.5 & 2.0 & 0.8 & 0.00016 & 0.00016 \\
\hline 2187 & 17.1 & 14 & 83 & 0.1 & 2.8 & 0.8 & 0.00044 & 0.00044 \\
\hline 0188 & 36.1 & 14 & 97 & 1.3 & 4.1 & 1.1 & 0.05591 & 0.00290 \\
\hline 0289 & 19.4 & 13 & 86 & 0.5 & 2.9 & 0.9 & 0.00160 & 0.00160 \\
\hline 0190 & 17.1 & 13 & 80 & 0.3 & 2.6 & 0.8 & 0.00057 & 0.00057 \\
\hline 3190 & 31.5 & 17 & 77 & 1.0 & 4.1 & 1.0 & 0.03565 & 0.00384 \\
\hline 2691 & 14.4 & 17 & 83 & 0.0 & 2.6 & 0.7 & 0.00025 & 0.00025 \\
\hline 1592 & 32.2 & 17 & 77 & 2.1 & 3.9 & 1.2 & 0.12209 & 0.00349 \\
\hline 3192 & 30.2 & 14 & 75 & 1.4 & 3.7 & 1.1 & 0.03611 & 0.00302 \\
\hline 3594 & - & - & - & - & - & - & 0.00000 & 0.00000 \\
\hline 0597 & 44.3 & 17 & 90 & 2.0 & 4.6 & 1.2 & 0.23652 & 0.01420 \\
\hline 2997 & 27.6 & 14 & 96 & 0.4 & 3.7 & 0.9 & 0.00762 & 0.00372 \\
\hline 5163 & 35.4 & 17 & 68 & 2.6 & 4.0 & 1.2 & 0.24123 & 0.01520 \\
\hline 6163 & 21.0 & 14 & 113 & 0.6 & 3.1 & 0.9 & 0.00295 & 0.00295 \\
\hline
\end{tabular}




\begin{tabular}{|c|c|c|c|c|c|c|c|c|}
\hline \multirow{2}{*}{ Storm } & \multicolumn{3}{|l|}{ Waves } & \multicolumn{3}{|c|}{ Water Level Components } & \multicolumn{2}{|c|}{$\begin{array}{l}\text { Max. Overtopping } \\
\text { Rates, cfs per ft }\end{array}$} \\
\hline & $\begin{array}{l}\text { Height } \\
\mathrm{ft}\end{array}$ & $\begin{array}{l}\text { Period } \\
\text { sec }\end{array}$ & $\begin{array}{l}\text { Angle } \\
\text { deg }\end{array}$ & $\begin{array}{l}\text { Storm } \\
\text { Surge } \\
\mathrm{ft}\end{array}$ & $\begin{array}{l}\text { Ponding } \\
\mathrm{ft}\end{array}$ & $\begin{array}{l}\text { Wave } \\
\text { Setup } \\
\mathrm{ft}\end{array}$ & $\begin{array}{l}\text { Existing } \\
\text { Profile }\end{array}$ & $\begin{array}{l}\text { Plan } \\
\text { Profile }\end{array}$ \\
\hline 2348 & 16.4 & 11 & 92 & 0.4 & 2.2 & 0.8 & 0.00022 & 0.00022 \\
\hline 0150 & 10.8 & 13 & 73 & 0.1 & 1.6 & 0.6 & 0.00001 & 0.00001 \\
\hline 0853 & 25.9 & 14 & 82 & 0.9 & 3.4 & 1.0 & 0.00942 & 0.00421 \\
\hline 1953 & 14.8 & 11 & 92 & 0.3 & 2.0 & 0.7 & 0.00010 & 0.00010 \\
\hline 1557 & 17.7 & 13 & 88 & 0.5 & 2.6 & 0.8 & 0.00064 & 0.00064 \\
\hline 2057 & 38.7 & 14 & 71 & 1.4 & 4.1 & 1.1 & 0.06492 & 0.00378 \\
\hline 1861 & 14.8 & 13 & 72 & 0.2 & 2.2 & 0.7 & 0.00011 & 0.00011 \\
\hline 2762 & 38.7 & 14 & 69 & 3.2 & 3.8 & 1.3 & 0.37845 & 0.05848 \\
\hline 0163 & 24.6 & 17 & 109 & 0.8 & 3.5 & 0.9 & 0.01015 & 0.00431 \\
\hline 2563 & 27.9 & 14 & 92 & 0.5 & 3.6 & 0.9 & 0.00678 & 0.00423 \\
\hline 2965 & 12.1 & 14 & 83 & 0.0 & 1.9 & 0.6 & 0.00002 & 0.00002 \\
\hline 3367 & 32.2 & 14 & 102 & 0.8 & 3.8 & 1.0 & 0.01804 & 0.00429 \\
\hline 2168 & 15.7 & 11 & 106 & 0.3 & 2.2 & 0.7 & 0.00013 & 0.00013 \\
\hline 0571 & 15.7 & 13 & 74 & 0.3 & 2.3 & 0.7 & 0.00021 & 0.00021 \\
\hline 0676 & 35.4 & 17 & 79 & 2.9 & 3.9 & 1.3 & 0.31060 & 0.03247 \\
\hline 1977 & 20.0 & 11 & 80 & 0.9 & 2.6 & 0.9 & 0.00173 & 0.00173 \\
\hline 2379 & 14.8 & 10 & 68 & 0.5 & 1.9 & 0.7 & 0.00011 & 0.00011 \\
\hline 2187 & 17.1 & 14 & 83 & 0.1 & 2.6 & 0.7 & 0.00029 & 0.00029 \\
\hline 0188 & 36.1 & 14 & 97 & 1.3 & 4.0 & 1.1 & 0.04895 & 0.00428 \\
\hline 0289 & 19.4 & 13 & 86 & 0.5 & 2.7 & 0.8 & 0.00117 & 0.00117 \\
\hline 0190 & 17.1 & 13 & 80 & 0.3 & 2.5 & 0.8 & 0.00039 & 0.00039 \\
\hline 3190 & 31.5 & 17 & 77 & 1.0 & 4.0 & 1.0 & 0.02990 & 0.00426 \\
\hline 2691 & 14.4 & 17 & 83 & 0.0 & 2.5 & 0.7 & 0.00016 & 0.00016 \\
\hline 1592 & 32.2 & 17 & 77 & 2.1 & 3.8 & 1.2 & 0.11336 & 0.00264 \\
\hline 3192 & 30.2 & 14 & 75 & 1.4 & 3.6 & 1.1 & 0.03128 & 0.00232 \\
\hline 3594 & - & - & - & - & - & - & 0.00000 & 0.00000 \\
\hline 0597 & 44.3 & 17 & 90 & 2.0 & 4.5 & 1.2 & 0.22330 & 0.01076 \\
\hline 2997 & 27.6 & 14 & 96 & 0.4 & 3.6 & 0.9 & 0.00582 & 0.00384 \\
\hline 5163 & 32.8 & 17 & 66 & 2.8 & 3.7 & 1.2 & 0.23040 & 0.01203 \\
\hline 6163 & 21.0 & 14 & 113 & 0.6 & 3.0 & 0.9 & 0.00221 & 0.00221 \\
\hline
\end{tabular}




\begin{tabular}{|c|c|c|c|c|c|c|c|c|}
\hline \multirow[b]{2}{*}{ Storm } & \multicolumn{3}{|l|}{ Waves } & \multicolumn{3}{|c|}{ Water Level Components } & \multicolumn{2}{|c|}{$\begin{array}{l}\text { Max. Overtopping } \\
\text { Rates, cfs per ft }\end{array}$} \\
\hline & $\begin{array}{l}\text { Height } \\
\mathrm{ft}\end{array}$ & $\begin{array}{l}\text { Period } \\
\text { sec }\end{array}$ & $\begin{array}{l}\text { Angle } \\
\text { deg }\end{array}$ & $\begin{array}{l}\text { Storm } \\
\text { Surge } \\
\mathrm{ft}\end{array}$ & $\begin{array}{l}\text { Ponding } \\
\mathrm{ft}\end{array}$ & $\begin{array}{l}\text { Wave } \\
\text { Setup } \\
\mathrm{ft}\end{array}$ & $\begin{array}{l}\text { Existing } \\
\text { Profile } \\
\end{array}$ & $\begin{array}{l}\text { Plan } \\
\text { Profile }\end{array}$ \\
\hline 2348 & 16.4 & 11 & 92 & 0.4 & 2.1 & 0.7 & 0.00014 & 0.00000 \\
\hline 0150 & - & - & - & - & - & - & 0.00000 & 0.00000 \\
\hline 0853 & 25.9 & 14 & 82 & 0.9 & 3.2 & 0.9 & 0.00143 & 0.00355 \\
\hline 1953 & 14.8 & 11 & 92 & 0.3 & 1.9 & 0.7 & 0.00006 & 0.00000 \\
\hline 1557 & 17.7 & 13 & 88 & 0.5 & 2.4 & 0.8 & 0.00043 & 0.00000 \\
\hline 2057 & 38.7 & 14 & 71 & 1.4 & 4.0 & 1.1 & 0.00575 & 0.00408 \\
\hline 1861 & 14.8 & 13 & 72 & 0.2 & 2.1 & 0.7 & 0.00006 & 0.00000 \\
\hline 2762 & 38.7 & 14 & 69 & 3.2 & 3.8 & 1.3 & 0.15057 & 0.03769 \\
\hline 0163 & 24.6 & 17 & 109 & 0.8 & 3.3 & 0.9 & 0.00847 & 0.00329 \\
\hline 2563 & 27.9 & 14 & 92 & 0.5 & 3.4 & 0.9 & 0.00116 & 0.00430 \\
\hline 2965 & 11.5 & 14 & 83 & 0.0 & 1.6 & 0.6 & 0.00001 & 0.00000 \\
\hline 3367 & 31.5 & 17 & 88 & 0.6 & 3.9 & 0.9 & 0.01081 & 0.00344 \\
\hline 2168 & 15.7 & 11 & 106 & 0.3 & 2.0 & 0.7 & 0.00008 & 0.00000 \\
\hline 0571 & 15.7 & 13 & 74 & 0.3 & 2.2 & 0.7 & 0.00013 & 0.00000 \\
\hline 0676 & 35.4 & 17 & 79 & 2.9 & 3.8 & 1.3 & 0.29645 & 0.03547 \\
\hline 1977 & 16.1 & 10 & 79 & 0.6 & 1.9 & 0.8 & 0.00021 & 0.00001 \\
\hline 2379 & 14.8 & 10 & 68 & 0.5 & 1.7 & 0.7 & 0.00007 & 0.00000 \\
\hline 2187 & 17.1 & 14 & 83 & 0.1 & 2.4 & 0.7 & 0.00017 & 0.00017 \\
\hline 0188 & 33.1 & 17 & 92 & 0.9 & 4.0 & 1.0 & 0.01561 & 0.00366 \\
\hline 0289 & 17.7 & 13 & 83 & 0.6 & 2.4 & 0.8 & 0.00067 & 0.00081 \\
\hline 0190 & 17.1 & 13 & 80 & 0.3 & 2.3 & 0.8 & 0.00025 & 0.00000 \\
\hline 3190 & 31.5 & 17 & 77 & 1.0 & 3.8 & 1.0 & 0.01531 & 0.00324 \\
\hline 2691 & 14.4 & 17 & 83 & 0.0 & 2.3 & 0.7 & 0.00009 & 0.00009 \\
\hline 1592 & 32.2 & 17 & 77 & 2.1 & 3.7 & 1.1 & 0.05279 & 0.00933 \\
\hline 3192 & 30.2 & 14 & 75 & 1.4 & 3.5 & 1.0 & 0.00321 & 0.00418 \\
\hline 3594 & - & - & - & - & - & - & 0.00000 & 0.00000 \\
\hline 0597 & 44.3 & 17 & 90 & 2.0 & 4.4 & 1.2 & 0.16562 & 0.02070 \\
\hline 2997 & 22.0 & 14 & 108 & 0.1 & 3.0 & 0.8 & 0.00107 & 0.00423 \\
\hline 5163 & 32.8 & 17 & 66 & 2.8 & 3.7 & 1.2 & 0.18114 & 0.02246 \\
\hline 6163 & 20.3 & 14 & 101 & 0.3 & 2.8 & 0.8 & 0.00103 & 0.00158 \\
\hline
\end{tabular}




\begin{tabular}{|c|c|c|c|c|c|c|c|c|}
\hline \multirow{2}{*}{ Storm } & \multicolumn{3}{|l|}{ Waves } & \multicolumn{3}{|c|}{ Water Level Components } & \multicolumn{2}{|c|}{$\begin{array}{l}\text { Max. Overtopping } \\
\text { Rates, cfs per ft }\end{array}$} \\
\hline & $\begin{array}{l}\text { Height } \\
\mathrm{ft}\end{array}$ & $\begin{array}{l}\text { Period } \\
\text { sec }\end{array}$ & $\begin{array}{l}\text { Angle } \\
\text { deg }\end{array}$ & $\begin{array}{l}\text { Storm } \\
\text { Surge } \\
\mathrm{ft}\end{array}$ & $\begin{array}{l}\text { Ponding } \\
\mathrm{ft}\end{array}$ & $\begin{array}{l}\text { Wave } \\
\text { Setup } \\
\mathrm{ft}\end{array}$ & $\begin{array}{l}\text { Existing } \\
\text { Profile }\end{array}$ & $\begin{array}{l}\text { Plan } \\
\text { Profile }\end{array}$ \\
\hline 2348 & 16.7 & 11 & 96 & 0.3 & 2.0 & 0.7 & 0.00008 & 0.00000 \\
\hline 0150 & - & - & - & - & - & - & 0.00000 & 0.00000 \\
\hline 0853 & 25.9 & 14 & 82 & 0.9 & 3.1 & 0.9 & 0.00576 & 0.00004 \\
\hline 1953 & 14.8 & 11 & 108 & 0.3 & 1.7 & 0.7 & 0.00003 & 0.00002 \\
\hline 1557 & 17.7 & 13 & 88 & 0.5 & 2.2 & 0.8 & 0.00027 & 0.00002 \\
\hline 2057 & 34.8 & 14 & 69 & 0.9 & 3.7 & 1.0 & 0.01246 & 0.00010 \\
\hline 1861 & 14.8 & 13 & 72 & 0.2 & 1.9 & 0.7 & 0.00003 & 0.00003 \\
\hline 2762 & 38.7 & 14 & 69 & 3.2 & 3.8 & 1.3 & 0.04237 & 0.00888 \\
\hline 0163 & 24.6 & 17 & 109 & 0.8 & 3.2 & 0.9 & 0.00613 & 0.00097 \\
\hline 2563 & 27.9 & 14 & 92 & 0.5 & 3.3 & 0.9 & 0.00354 & 0.00007 \\
\hline 2965 & - & - & - & - & - & - & 0.00000 & 0.00000 \\
\hline 3367 & 32.2 & 14 & 102 & 0.8 & 3.5 & 1.0 & 0.01120 & 0.00013 \\
\hline 2168 & 15.7 & 11 & 106 & 0.3 & 1.8 & 0.7 & 0.00005 & 0.00003 \\
\hline 0571 & 15.4 & 13 & 72 & 0.3 & 2.0 & 0.7 & 0.00007 & 0.00002 \\
\hline 0676 & 35.4 & 17 & 79 & 2.9 & 3.8 & 1.3 & 0.03026 & 0.02350 \\
\hline 1977 & 20.0 & 11 & 80 & 0.9 & 2.3 & 0.8 & 0.00095 & 0.00003 \\
\hline 2379 & 14.8 & 10 & 68 & 0.5 & 1.6 & 0.7 & 0.00004 & 0.00000 \\
\hline 2187 & 17.1 & 14 & 83 & 0.1 & 2.3 & 0.7 & 0.00010 & 0.00009 \\
\hline 0188 & 33.1 & 17 & 92 & 0.7 & 3.8 & 1.0 & 0.01452 & 0.00009 \\
\hline 0289 & 19.4 & 13 & 86 & 0.5 & 2.4 & 0.8 & 0.00054 & 0.00000 \\
\hline 0190 & 17.1 & 13 & 80 & 0.3 & 2.2 & 0.7 & 0.00015 & 0.00004 \\
\hline 3190 & 33.8 & 14 & 71 & 0.9 & 3.6 & 1.0 & 0.01433 & 0.00006 \\
\hline 2691 & 14.4 & 17 & 83 & 0.0 & 2.1 & 0.6 & 0.00005 & 0.00005 \\
\hline 1592 & 29.9 & 14 & 71 & 1.1 & 3.4 & 1.0 & 0.01451 & 0.00129 \\
\hline 3192 & 28.9 & 13 & 87 & 1.2 & 3.2 & 1.0 & 0.01277 & 0.00010 \\
\hline 3594 & - & - & - & - & - & - & 0.00000 & 0.00000 \\
\hline 0597 & 44.3 & 17 & 90 & 2.0 & 4.3 & 1.2 & 0.01556 & 0.00817 \\
\hline 2997 & 26.9 & 14 & 92 & 0.5 & 3.2 & 0.9 & 0.00299 & 0.00009 \\
\hline 5163 & 32.8 & 17 & 66 & 2.8 & 3.7 & 1.2 & 0.01778 & 0.01015 \\
\hline 6163 & 21.0 & 14 & 113 & 0.6 & 2.7 & 0.8 & 0.00108 & 0.00020 \\
\hline
\end{tabular}




\section{Appendix E Stage-Frequency Relationship Tables for Harbor Side}

This appendix contains stage-frequency relationship values for storm surge stations along the south side of Cabras Island, Guam. Maximum water level and its standard deviation are given for six return intervals for each station. Maximum water level includes tide, storm surge, and significant wave height effects, referenced to mean sea level datum. Water levels represent the highest level reached by the crest of the significant wave. ${ }^{1}$

1 Maximum water level and water level standard deviation are in feet in all tables in this appendix. To convert feet to meters, multiply by 0.3048 . 


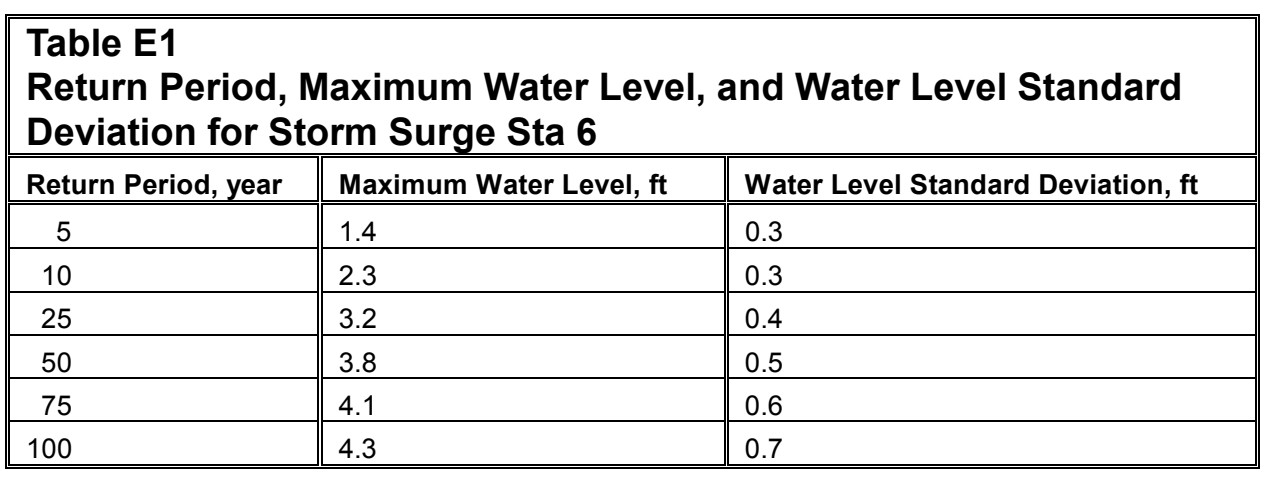

\begin{tabular}{|c|c|c|}
\hline \multicolumn{3}{|c|}{$\begin{array}{l}\text { Table E2 } \\
\text { Return Period, Maximum Water Level, and Water Level Standard } \\
\text { Deviation for Storm Surge Sta } 7\end{array}$} \\
\hline Return Period, year & Maximum Water Level, $\mathrm{ft}$ & Water Level Standard Deviation, $\mathrm{ft}$ \\
\hline 5 & $\begin{array}{l}1.8 \\
\end{array}$ & 0.4 \\
\hline 10 & 3.0 & 0.5 \\
\hline 25 & 4.8 & 0.8 \\
\hline 50 & 6.0 & 1.1 \\
\hline 75 & 7.0 & 1.3 \\
\hline 100 & 7.4 & 1.6 \\
\hline
\end{tabular}

\begin{tabular}{|c|c|c|}
\hline \multicolumn{3}{|c|}{$\begin{array}{l}\text { Table E3 } \\
\text { Return Period, Maximum Water Level, and Water Level Standard } \\
\text { Deviation for Storm Surge Sta } 8\end{array}$} \\
\hline Return Period, year & Maximum Water Level, $\mathrm{ft}$ & Water Level Standard Deviation, $\mathrm{ft}$ \\
\hline 5 & 2.5 & 0.4 \\
\hline 10 & 3.9 & 0.6 \\
\hline 25 & 5.9 & 0.8 \\
\hline 50 & 7.0 & 1.1 \\
\hline 75 & 8.0 & 1.3 \\
\hline 100 & 8.4 & 1.5 \\
\hline
\end{tabular}

\begin{tabular}{|c|c|c|}
\hline \multicolumn{3}{|c|}{$\begin{array}{l}\text { Table E4 } \\
\text { Return Period, Maximum Water Level, and Water Level Standard } \\
\text { Deviation for Storm Surge Sta } 9\end{array}$} \\
\hline Return Period, year & Maximum Water Level, ft & Water Level Standard Deviation, $\mathrm{ft}$ \\
\hline 5 & 2.8 & 0.5 \\
\hline 10 & 4.5 & 0.6 \\
\hline 25 & 6.8 & 1.1 \\
\hline 50 & 8.4 & 1.5 \\
\hline 75 & 9.8 & 1.8 \\
\hline 100 & 10.5 & 2.2 \\
\hline
\end{tabular}




\begin{tabular}{|c|c|c|}
\hline \multicolumn{3}{|c|}{$\begin{array}{l}\text { Table E5 } \\
\text { Return Period, Maximum Water Level, and Water Level Standard } \\
\text { Deviation for Storm Surge Sta } 10\end{array}$} \\
\hline Return Period, year & Maximum Water Level, ft & Water Level Standard Deviation, ft \\
\hline 5 & 2.9 & 0.5 \\
\hline 10 & 4.5 & 0.6 \\
\hline 25 & 6.8 & 1.1 \\
\hline 50 & 8.5 & 1.6 \\
\hline 75 & 10.0 & 2.0 \\
\hline 100 & 10.7 & 2.5 \\
\hline
\end{tabular}

\begin{tabular}{|c|c|c|}
\hline \multicolumn{3}{|c|}{$\begin{array}{l}\text { Table E6 } \\
\text { Return Period, Maximum Water Level, and Water Level Standard } \\
\text { Deviation for Storm Surge Sta } 11\end{array}$} \\
\hline Return Period, year & Maximum Water Level, ft & Water Level Standard Deviation, $\mathrm{ft}$ \\
\hline 5 & 3.3 & 0.6 \\
\hline 10 & 5.4 & 0.7 \\
\hline 25 & 7.8 & 1.2 \\
\hline 50 & 9.5 & 1.7 \\
\hline 75 & 10.9 & 2.0 \\
\hline 100 & 11.7 & 2.5 \\
\hline
\end{tabular}

\begin{tabular}{|c|c|c|}
\hline \multicolumn{3}{|c|}{$\begin{array}{l}\text { Table E7 } \\
\text { Return Period, Maximum Water Level, and Water Level Standard } \\
\text { Deviation for Storm Surge Sta } 12\end{array}$} \\
\hline Return Period, year & Maximum Water Level, ft & Water Level Standard Deviation, $\mathrm{ft}$ \\
\hline 5 & 3.3 & 0.5 \\
\hline 10 & 5.1 & 0.6 \\
\hline 25 & 7.1 & 0.9 \\
\hline 50 & 8.3 & 1.2 \\
\hline 75 & 9.3 & 1.4 \\
\hline 100 & 9.8 & 1.7 \\
\hline
\end{tabular}




\section{Appendix $F$}

\section{Tables of Wave Parameters and Water Levels by Storm at Harbor Side Storm Surge Stations}

Tables of wave and wind parameters and water levels corresponding to the maximum water level for each storm are provided for each storm surge station along the south side of Cabras Island. Offshore wave heights are the deepwater significant wave heights calculated outside the entrance to Apra Harbor. The offshore wave heights and wind speeds correspond to peak water level at the storm surge station and may not be the maximum wave heights and wind speeds during the storm. Local significant wave heights include waves due to diffraction through the entrance to Apra Harbor and waves generated locally inside the harbor.

Total water level includes local storm surge, a tide level of mean high water, and incident and reflected significant wave height at the station. The reference datum is mean sea level. Total water level is the maximum level reached when a significant wave representing the combined effect of diffracted and locallygenerated waves impacts the commercial dock and other areas along the south side of Cabras Island. Thus, the total water level is only reached intermittently by the higher waves during the most intense part of the storm relative to Apra Harbor. ${ }^{1}$

\footnotetext{
1 All waves and water levels are in feet in all tables in this appendix. To convert feet to meters, multiply by 0.3048 .
} 


\begin{tabular}{|c|c|c|c|c|c|c|c|c|c|}
\hline \multirow[b]{2}{*}{ Storm } & \multicolumn{3}{|c|}{ Offshore Waves } & \multicolumn{2}{|c|}{ Local Wind } & \multicolumn{2}{|c|}{ Local Waves } & \multicolumn{2}{|c|}{ Water Level } \\
\hline & $\begin{array}{l}\text { Height } \\
\mathrm{ft}\end{array}$ & $\begin{array}{l}\text { Period } \\
\text { sec }\end{array}$ & $\begin{array}{l}\text { Angle } \\
\text { deg }\end{array}$ & $\begin{array}{l}\text { Speed } \\
\mathrm{mph}\end{array}$ & $\begin{array}{l}\text { Dir.d } \\
\text { eg }\end{array}$ & $\begin{array}{l}H_{\text {sdiff }} \\
\mathrm{ft}\end{array}$ & $\begin{array}{l}H_{\text {sloc }} \\
\mathrm{ft} \\
\end{array}$ & $\begin{array}{l}\text { Storm } \\
\text { Surge } \\
\mathrm{ft} \\
\end{array}$ & $\begin{array}{l}\text { Total } \\
\mathrm{ft}\end{array}$ \\
\hline 2348 & 23.0 & 10 & 310 & 54 & 270 & 0.3 & 0.0 & 0.7 & 1.6 \\
\hline 0150 & 19.7 & 14 & 230 & 38 & 120 & 0.0 & 0.0 & 0.0 & 1.0 \\
\hline 0853 & 39.4 & 14 & 356 & 0 & - & 0.0 & 0.0 & 1.3 & 2.1 \\
\hline 1953 & 20.3 & 10 & 346 & 0 & - & 0.0 & 0.0 & 0.6 & 1.5 \\
\hline 1557 & 26.2 & 11 & 328 & 0 & - & 0.0 & 0.0 & 0.7 & 1.6 \\
\hline 2057 & 57.1 & 14 & 11 & 0 & - & 0.0 & 0.0 & 0.5 & 1.4 \\
\hline 1861 & 0.0 & - & - & 0 & - & 0.0 & 0.0 & 0.0 & 0.9 \\
\hline 2762 & 59.4 & 14 & 356 & 0 & - & 0.0 & 0.0 & 2.4 & 3.3 \\
\hline 0163 & 46.3 & 14 & 241 & 90 & 220 & 0.4 & 0.0 & 1.7 & 2.8 \\
\hline 2563 & 38.7 & 13 & 274 & 67 & 235 & 0.4 & 0.0 & 1.1 & 2.2 \\
\hline 2965 & 16.1 & 9 & 284 & 34 & 240 & 0.2 & 0.0 & 0.2 & 1.1 \\
\hline 3367 & 49.5 & 14 & 302 & 76 & 235 & 0.4 & 0.0 & 1.5 & 2.6 \\
\hline 2168 & 26.6 & 11 & 256 & 47 & 225 & 0.4 & 0.0 & 0.4 & 1.5 \\
\hline 0571 & 29.2 & 17 & 270 & 45 & 170 & 0.2 & 0.0 & 0.8 & 1.7 \\
\hline 0676 & 41.0 & 14 & 346 & 76 & 270 & 0.0 & 0.0 & 3.1 & 3.9 \\
\hline 1977 & 19.4 & 11 & 349 & 0 & - & 0.0 & 0.0 & 0.9 & 1.8 \\
\hline 2379 & 17.4 & 8 & 4 & 0 & - & 0.0 & 0.0 & 0.2 & 1.1 \\
\hline 2187 & 24.9 & 11 & 295 & 43 & 250 & 0.3 & 0.0 & 0.3 & 1.4 \\
\hline 0188 & 52.2 & 14 & 310 & 87 & 250 & 0.4 & 0.0 & 2.2 & 3.3 \\
\hline 0289 & 29.9 & 13 & 349 & 27 & 320 & 0.0 & 0.0 & 0.6 & 1.5 \\
\hline 0190 & 24.9 & 13 & 4 & 0 & - & 0.0 & 0.0 & 0.4 & 1.4 \\
\hline 3190 & 49.5 & 14 & 11 & 0 & - & 0.0 & 0.0 & 0.3 & 1.2 \\
\hline 2691 & 10.8 & 14 & 331 & 18 & 180 & 0.0 & 0.0 & 0.2 & 1.1 \\
\hline 1592 & 35.1 & 14 & 0 & 43 & 215 & 0.0 & 0.0 & 2.3 & 3.2 \\
\hline 3192 & 35.1 & 14 & 11 & 0 & - & 0.0 & 0.0 & 1.3 & 2.2 \\
\hline 3594 & 7.2 & 7 & 338 & 0 & - & 0.0 & 0.0 & 0.0 & 0.9 \\
\hline 0597 & 65.0 & 17 & 313 & 98 & 250 & 0.4 & 0.0 & 2.9 & 4.0 \\
\hline 2997 & 36.7 & 13 & 302 & 69 & 245 & 0.4 & 0.0 & 1.2 & 2.3 \\
\hline 5163 & 64.6 & 17 & 29 & 0 & - & 0.0 & 0.0 & 2.4 & 3.3 \\
\hline 6163 & 44.0 & 14 & 259 & 67 & 205 & 0.4 & 0.0 & 1.2 & 2.3 \\
\hline
\end{tabular}




\begin{tabular}{|c|c|c|c|c|c|c|c|c|c|}
\hline \multirow[b]{2}{*}{ Storm } & \multicolumn{3}{|c|}{ Offshore Waves } & \multicolumn{2}{|c|}{ Local Wind } & \multicolumn{2}{|c|}{ Local Waves } & \multicolumn{2}{|c|}{ Water Level } \\
\hline & $\begin{array}{l}\text { Height } \\
\mathrm{ft}\end{array}$ & $\begin{array}{l}\text { Period } \\
\text { sec }\end{array}$ & $\begin{array}{l}\text { Angle } \\
\text { deg }\end{array}$ & $\begin{array}{l}\text { Speed } \\
\mathrm{mph}\end{array}$ & $\begin{array}{l}\text { Dir. } \\
\text { deg }\end{array}$ & $\begin{array}{l}H_{\text {sdiff }} \\
\mathrm{ft}\end{array}$ & $\begin{array}{l}H_{\text {sloc }} \\
\mathrm{ft} \\
\end{array}$ & $\begin{array}{l}\text { Storm } \\
\text { Surge } \\
\mathrm{ft} \\
\end{array}$ & $\begin{array}{l}\text { Total } \\
\mathrm{ft}\end{array}$ \\
\hline 2348 & 23.0 & 10 & 310 & 54 & 270 & 0.4 & 1.9 & 0.7 & 2.5 \\
\hline 0150 & 19.7 & 14 & 230 & 38 & 120 & 0.0 & 0.0 & 0.1 & 1.0 \\
\hline 0853 & 35.4 & 14 & 342 & 54 & 255 & 0.0 & 1.3 & 1.0 & 2.5 \\
\hline 1953 & 20.3 & 10 & 320 & 40 & 270 & 0.0 & 1.3 & 0.5 & 2.1 \\
\hline 1557 & 27.2 & 13 & 338 & 45 & 260 & 0.0 & 1.5 & 0.5 & 2.2 \\
\hline 2057 & 51.8 & 14 & 14 & 0 & - & 0.0 & 0.0 & 0.6 & 1.5 \\
\hline 1861 & 0 & - & - & 0 & - & 0.0 & 0.0 & 0.0 & 0.9 \\
\hline 2762 & 59.4 & 14 & 356 & 0 & - & 0.0 & 0.0 & 2.3 & 3.2 \\
\hline 0163 & 46.3 & 14 & 241 & 90 & 220 & 0.6 & 0.0 & 1.6 & 2.8 \\
\hline 2563 & 33.8 & 13 & 342 & 65 & 270 & 0.0 & 2.4 & 1.0 & 3.0 \\
\hline 2965 & 12.8 & 8 & 302 & 31 & 270 & 0.2 & 1.0 & 0.2 & 1.6 \\
\hline 3367 & 46.3 & 14 & 338 & 76 & 260 & 0.0 & 2.9 & 1.4 & 3.8 \\
\hline 2168 & 20.3 & 11 & 353 & 40 & 260 & 0.0 & 1.3 & 0.5 & 2.0 \\
\hline 0571 & 29.2 & 17 & 270 & 45 & 170 & 0.4 & 0.0 & 0.8 & 1.9 \\
\hline 0676 & 41.0 & 14 & 346 & 76 & 270 & 0.0 & 2.9 & 3.0 & 5.4 \\
\hline 1977 & 19.4 & 11 & 349 & 36 & 355 & 0.0 & 0.0 & 0.9 & 1.8 \\
\hline 2379 & 17.4 & 8 & 4 & 31 & 10 & 0.0 & 0.0 & 0.2 & 1.1 \\
\hline 2187 & 24.3 & 11 & 320 & 43 & 270 & 0.0 & 1.4 & 0.4 & 2.0 \\
\hline 0188 & 50.9 & 14 & 331 & 92 & 270 & 0.0 & 3.6 & 2.0 & 4.7 \\
\hline 0289 & 29.9 & 13 & 349 & 27 & 320 & 0.0 & 0.0 & 0.6 & 1.5 \\
\hline 0190 & 23.6 & 13 & 349 & 40 & 270 & 0.0 & 1.3 & 0.4 & 1.9 \\
\hline 3190 & 49.5 & 14 & 11 & 0 & - & 0.0 & 0.0 & 0.3 & 1.3 \\
\hline 2691 & 20.0 & 10 & 313 & 40 & 270 & 0.3 & 1.3 & 0.0 & 1.6 \\
\hline 1592 & 35.1 & 14 & 0 & 43 & 215 & 0.0 & 0.0 & 2.3 & 3.2 \\
\hline 3192 & 32.2 & 14 & 11 & 58 & 135 & 0.0 & 0.0 & 1.3 & 2.2 \\
\hline 3594 & 11.5 & 8 & 302 & 27 & 260 & 0.2 & 0.8 & -0.1 & 1.2 \\
\hline 0597 & 68.9 & 17 & 342 & 105 & 270 & 0.0 & 4.3 & 2.9 & 6.0 \\
\hline 2997 & 32.8 & 13 & 349 & 67 & 270 & 0.0 & 2.5 & 1.0 & 3.2 \\
\hline 5163 & 47.9 & 14 & 313 & 72 & 270 & 0.6 & 2.7 & 1.6 & 3.8 \\
\hline 6163 & 43.6 & 14 & 252 & 69 & 200 & 0.6 & 0.0 & 1.2 & 2.4 \\
\hline
\end{tabular}




\begin{tabular}{|c|c|c|c|c|c|c|c|c|c|}
\hline \multirow[b]{2}{*}{ Storm } & \multicolumn{3}{|c|}{ Offshore Waves } & \multicolumn{2}{|c|}{ Local Wind } & \multicolumn{2}{|c|}{ Local Waves } & \multicolumn{2}{|c|}{ Water Level } \\
\hline & $\begin{array}{l}\text { Height } \\
\mathrm{ft}\end{array}$ & $\begin{array}{l}\text { Period } \\
\text { sec }\end{array}$ & $\begin{array}{l}\text { Angle } \\
\text { deg }\end{array}$ & $\begin{array}{l}\text { Speed } \\
\mathrm{mph}\end{array}$ & $\begin{array}{l}\text { Dir. } \\
\text { deg }\end{array}$ & $\begin{array}{l}H_{\text {sdiff }} \\
\mathrm{ft}\end{array}$ & $\begin{array}{l}H_{\text {sloc }} \\
\mathrm{ft} \\
\end{array}$ & $\begin{array}{l}\text { Storm } \\
\text { Surge } \\
\mathrm{ft} \\
\end{array}$ & $\begin{array}{l}\text { Total } \\
\mathrm{ft}\end{array}$ \\
\hline 2348 & 24.0 & 11 & 338 & 54 & 250 & 0.0 & 2.7 & 0.6 & 2.9 \\
\hline 0150 & 20.0 & 14 & 227 & 40 & 120 & 0.0 & 0.7 & 0.1 & 1.3 \\
\hline 0853 & 35.4 & 14 & 342 & 54 & 255 & 0.0 & 3.6 & 0.9 & 3.6 \\
\hline 1953 & 20.3 & 10 & 299 & 40 & 245 & 0.9 & 1.5 & 0.5 & 2.2 \\
\hline 1557 & 27.2 & 13 & 338 & 45 & 260 & 0.0 & 3.5 & 0.5 & 3.2 \\
\hline 2057 & 32.2 & 14 & 22 & 85 & 95 & 0.0 & 1.6 & -0.1 & 1.6 \\
\hline 1861 & 23.0 & 17 & 194 & 54 & 95 & 0.0 & 0.9 & -0.1 & 1.3 \\
\hline 2762 & 44.9 & 14 & 7 & 98 & 120 & 0.0 & 2.0 & 1.8 & 3.7 \\
\hline 0163 & 46.3 & 14 & 241 & 90 & 220 & 1.4 & 1.8 & 1.6 & 3.6 \\
\hline 2563 & 35.8 & 13 & 313 & 67 & 255 & 1.2 & 4.8 & 0.9 & 4.3 \\
\hline 2965 & 13.5 & 9 & 335 & 31 & 260 & 0.0 & 2.2 & 0.1 & 2.1 \\
\hline 3367 & 46.3 & 14 & 338 & 76 & 260 & 0.0 & 6.6 & 1.3 & 5.5 \\
\hline 2168 & 20.3 & 11 & 353 & 40 & 260 & 0.0 & 3.0 & 0.5 & 2.9 \\
\hline 0571 & 29.2 & 17 & 270 & 45 & 170 & 0.8 & 0.7 & 0.8 & 2.2 \\
\hline 0676 & 43.0 & 14 & 320 & 83 & 250 & 0.0 & 4.7 & 2.6 & 5.8 \\
\hline 1977 & 20.0 & 11 & 356 & 34 & 175 & 0.0 & 0.5 & 0.8 & 1.9 \\
\hline 2379 & 13.1 & 11 & 25 & 63 & 95 & 0.0 & 1.1 & -0.1 & 1.4 \\
\hline 2187 & 24.6 & 11 & 306 & 43 & 260 & 1.0 & 3.2 & 0.3 & 2.9 \\
\hline 0188 & 52.2 & 14 & 310 & 87 & 250 & 1.5 & 5.0 & 1.9 & 5.4 \\
\hline 0289 & 29.9 & 13 & 349 & 27 & 320 & 0.0 & 0.0 & 0.6 & 1.5 \\
\hline 0190 & 22.3 & 14 & 14 & 36 & 260 & 0.0 & 2.6 & 0.3 & 2.5 \\
\hline 3190 & 28.9 & 14 & 191 & 63 & 120 & 0.0 & 1.1 & 0.3 & 1.8 \\
\hline 2691 & 21.0 & 11 & 349 & 40 & 260 & 0.0 & 3.0 & 0.0 & 2.4 \\
\hline 1592 & 35.1 & 14 & 0 & 43 & 215 & 0.0 & 0.7 & 2.3 & 3.5 \\
\hline 3192 & 32.2 & 14 & 11 & 58 & 135 & 0.0 & 1.2 & 1.4 & 2.8 \\
\hline 3594 & 11.5 & 8 & 302 & 27 & 260 & 0.5 & 1.8 & -0.1 & 1.8 \\
\hline 0597 & 65.0 & 17 & 313 & 98 & 250 & 1.4 & 5.8 & 2.6 & 6.5 \\
\hline 2997 & 35.8 & 13 & 331 & 69 & 255 & 0.0 & 5.0 & 1.0 & 4.4 \\
\hline 5163 & 47.9 & 14 & 313 & 72 & 270 & 1.4 & 2.8 & 1.4 & 3.9 \\
\hline 6163 & 44.6 & 14 & 248 & 72 & 190 & 1.4 & 1.2 & 1.1 & 2.9 \\
\hline
\end{tabular}




\begin{tabular}{|c|c|c|c|c|c|c|c|c|c|}
\hline \multirow[b]{2}{*}{ Storm } & \multicolumn{3}{|c|}{ Offshore Waves } & \multicolumn{2}{|c|}{ Local Wind } & \multicolumn{2}{|c|}{ Local Waves } & \multicolumn{2}{|c|}{ Water Level } \\
\hline & $\begin{array}{l}\text { Height } \\
\mathrm{ft}\end{array}$ & $\begin{array}{l}\text { Period } \\
\text { sec }\end{array}$ & $\begin{array}{l}\text { Angle } \\
\text { deg }\end{array}$ & $\begin{array}{l}\text { Speed } \\
\mathrm{mph}\end{array}$ & $\begin{array}{l}\text { Dir. } \\
\text { deg }\end{array}$ & $\begin{array}{l}H_{\text {sdiff }} \\
\mathrm{ft}\end{array}$ & $\begin{array}{l}H_{\text {sloc }} \\
\mathrm{ft}\end{array}$ & $\begin{array}{l}\text { Storm } \\
\text { Surge } \\
\mathrm{ft} \\
\end{array}$ & $\begin{array}{l}\text { Total } \\
\mathrm{ft}\end{array}$ \\
\hline 2348 & 24.0 & 11 & 338 & 54 & 250 & 0.0 & 4.0 & 0.6 & 3.5 \\
\hline 0150 & 15.1 & 14 & 184 & 54 & 95 & 0.0 & 1.4 & -0.1 & 1.5 \\
\hline 0853 & 35.4 & 14 & 342 & 54 & 255 & 0.0 & 4.0 & 0.9 & 3.8 \\
\hline 1953 & 20.3 & 10 & 299 & 40 & 245 & 1.8 & 2.4 & 0.5 & 2.9 \\
\hline 1557 & 27.2 & 13 & 338 & 45 & 260 & 0.0 & 3.2 & 0.5 & 3.0 \\
\hline 2057 & 32.2 & 14 & 22 & 85 & 95 & 0.0 & 2.4 & -0.1 & 2.0 \\
\hline 1861 & 20.0 & 17 & 245 & 38 & 125 & 1.5 & 0.8 & -0.1 & 1.6 \\
\hline 2762 & 44.9 & 14 & 7 & 98 & 120 & 0.0 & 2.9 & 1.9 & 4.3 \\
\hline 0163 & 49.5 & 17 & 288 & 69 & 240 & 3.1 & 3.4 & 1.2 & 4.4 \\
\hline 2563 & 35.8 & 13 & 313 & 67 & 255 & 2.3 & 5.3 & 0.9 & 4.6 \\
\hline 2965 & 15.1 & 9 & 310 & 34 & 250 & 1.3 & 2.3 & 0.1 & 2.3 \\
\hline 3367 & 47.9 & 14 & 320 & 76 & 250 & 0.0 & 6.2 & 1.3 & 5.3 \\
\hline 2168 & 22.3 & 11 & 338 & 43 & 250 & 0.0 & 3.0 & 0.4 & 2.8 \\
\hline 0571 & 29.2 & 17 & 270 & 45 & 170 & 2.1 & 0.8 & 0.8 & 2.8 \\
\hline 0676 & 43.0 & 14 & 320 & 83 & 250 & 0.0 & 6.9 & 2.5 & 6.9 \\
\hline 1977 & 22.3 & 11 & 245 & 56 & 170 & 2.1 & 1.0 & 0.3 & 2.4 \\
\hline 2379 & 19.0 & 10 & 32 & 63 & 90 & 0.0 & 1.7 & 0.0 & 1.7 \\
\hline 2187 & 24.9 & 11 & 295 & 43 & 250 & 2.2 & 3.0 & 0.3 & 3.0 \\
\hline 0188 & 52.2 & 14 & 310 & 87 & 250 & 3.0 & 7.3 & 1.8 & 6.7 \\
\hline 0289 & 28.5 & 13 & 349 & 27 & 325 & 0.0 & 0.0 & 0.6 & 1.5 \\
\hline 0190 & 21.0 & 14 & 14 & 36 & 255 & 0.0 & 2.4 & 0.2 & 2.3 \\
\hline 3190 & 26.6 & 14 & 22 & 81 & 95 & 0.0 & 2.3 & 0.1 & 2.2 \\
\hline 2691 & 22.0 & 11 & 335 & 40 & 250 & 0.0 & 2.8 & 0.0 & 2.3 \\
\hline 1592 & 35.8 & 14 & 317 & 81 & 195 & 2.0 & 1.6 & 1.6 & 3.8 \\
\hline 3192 & 32.2 & 14 & 11 & 58 & 135 & 0.0 & 1.2 & 1.4 & 2.8 \\
\hline 3594 & 11.2 & 7 & 277 & 27 & 260 & 1.1 & 1.7 & -0.1 & 1.8 \\
\hline 0597 & 65.0 & 17 & 313 & 98 & 250 & 3.3 & 8.5 & 2.5 & 8.0 \\
\hline 2997 & 35.8 & 13 & 331 & 69 & 255 & 0.0 & 5.5 & 1.0 & 4.6 \\
\hline 5163 & 47.9 & 14 & 313 & 72 & 270 & 2.7 & 2.4 & 1.4 & 4.1 \\
\hline 6163 & 44.6 & 14 & 248 & 72 & 190 & 2.9 & 1.3 & 1.1 & 3.6 \\
\hline
\end{tabular}




\begin{tabular}{|c|c|c|c|c|c|c|c|c|c|}
\hline \multirow[b]{2}{*}{ Storm } & \multicolumn{3}{|c|}{ Offshore Waves } & \multicolumn{2}{|c|}{ Local Wind } & \multicolumn{2}{|c|}{ Local Waves } & \multicolumn{2}{|c|}{ Water Level } \\
\hline & $\begin{array}{l}\text { Height } \\
\mathrm{ft}\end{array}$ & $\begin{array}{l}\text { Period } \\
\text { sec }\end{array}$ & $\begin{array}{l}\text { Angle } \\
\text { deg }\end{array}$ & $\begin{array}{l}\text { Speed } \\
\mathrm{mph}\end{array}$ & $\begin{array}{l}\text { Dir. } \\
\text { deg }\end{array}$ & $\begin{array}{l}H_{\text {sdiff }} \\
\mathrm{ft}\end{array}$ & $\begin{array}{l}H_{\text {sloc }} \\
\mathrm{ft} \\
\end{array}$ & $\begin{array}{l}\text { Storm } \\
\text { Surge } \\
\mathrm{ft}\end{array}$ & $\begin{array}{l}\text { Total } \\
\mathrm{ft}\end{array}$ \\
\hline 2348 & 24.0 & 11 & 338 & 54 & 250 & 0.0 & 3.9 & 0.6 & 3.4 \\
\hline 0150 & 15.1 & 14 & 184 & 54 & 95 & 0.0 & 1.7 & -0.1 & 1.7 \\
\hline 0853 & 35.4 & 14 & 342 & 54 & 255 & 0.0 & 3.7 & 0.9 & 3.6 \\
\hline 1953 & 20.3 & 10 & 299 & 40 & 245 & 1.7 & 2.3 & 0.4 & 2.8 \\
\hline 1557 & 26.6 & 13 & 331 & 45 & 255 & 0.0 & 2.9 & 0.4 & 2.8 \\
\hline 2057 & 32.2 & 14 & 22 & 85 & 95 & 0.0 & 3.0 & 0.0 & 2.4 \\
\hline 1861 & 20.0 & 17 & 245 & 38 & 125 & 2.7 & 0.8 & -0.1 & 2.2 \\
\hline 2762 & 44.9 & 14 & 7 & 98 & 120 & 0.0 & 2.8 & 2.0 & 4.3 \\
\hline 0163 & 49.5 & 17 & 288 & 69 & 240 & 5.2 & 3.1 & 1.1 & 5.1 \\
\hline 2563 & 35.8 & 13 & 313 & 67 & 255 & 2.3 & 4.8 & 0.8 & 4.4 \\
\hline 2965 & 15.1 & 9 & 310 & 34 & 250 & 1.2 & 2.2 & 0.1 & 2.3 \\
\hline 3367 & 47.9 & 14 & 320 & 76 & 250 & 0.0 & 6.0 & 1.2 & 5.1 \\
\hline 2168 & 22.3 & 11 & 338 & 43 & 250 & 0.0 & 2.9 & 0.4 & 2.8 \\
\hline 0571 & 29.2 & 17 & 270 & 45 & 170 & 3.7 & 0.8 & 0.8 & 3.6 \\
\hline 0676 & 43.0 & 14 & 320 & 83 & 250 & 0.0 & 6.7 & 2.5 & 6.7 \\
\hline 1977 & 22.3 & 11 & 245 & 56 & 170 & 2.0 & 1.0 & 0.3 & 2.3 \\
\hline 2379 & 19.0 & 10 & 32 & 63 & 90 & 0.0 & 2.1 & 0.0 & 2.0 \\
\hline 2187 & 24.9 & 11 & 295 & 43 & 250 & 2.1 & 2.9 & 0.3 & 3.0 \\
\hline 0188 & 52.2 & 14 & 310 & 87 & 250 & 3.3 & 7.1 & 1.8 & 6.6 \\
\hline 0289 & 28.5 & 13 & 349 & 27 & 325 & 0.0 & 0.0 & 0.6 & 1.5 \\
\hline 0190 & 21.0 & 14 & 14 & 36 & 255 & 0.0 & 2.2 & 0.2 & 2.2 \\
\hline 3190 & 26.6 & 14 & 22 & 81 & 95 & 0.0 & 2.8 & 0.2 & 2.5 \\
\hline 2691 & 22.0 & 11 & 335 & 40 & 250 & 0.0 & 2.8 & 0.0 & 2.2 \\
\hline 1592 & 35.8 & 14 & 317 & 81 & 195 & 2.2 & 1.7 & 1.6 & 3.9 \\
\hline 3192 & 32.2 & 14 & 11 & 58 & 135 & 0.0 & 1.2 & 1.4 & 2.9 \\
\hline 3594 & 11.2 & 7 & 277 & 27 & 260 & 1.0 & 1.5 & -0.1 & 1.7 \\
\hline 0597 & 65.0 & 17 & 313 & 98 & 250 & 5.4 & 8.3 & 2.5 & 8.3 \\
\hline 2997 & 36.7 & 13 & 302 & 69 & 245 & 2.5 & 4.4 & 0.9 & 4.4 \\
\hline 5163 & 47.9 & 14 & 313 & 72 & 270 & 3.0 & 1.9 & 1.4 & 4.0 \\
\hline 6163 & 43.6 & 14 & 252 & 69 & 200 & 3.3 & 1.5 & 1.1 & 3.8 \\
\hline
\end{tabular}




\begin{tabular}{|c|c|c|c|c|c|c|c|c|c|}
\hline \multirow[b]{2}{*}{ Storm } & \multicolumn{3}{|c|}{ Offshore Waves } & \multicolumn{2}{|c|}{ Local Wind } & \multicolumn{2}{|c|}{ Local Waves } & \multicolumn{2}{|c|}{ Water Level } \\
\hline & $\begin{array}{l}\text { Height } \\
\mathrm{ft}\end{array}$ & $\begin{array}{l}\text { Period } \\
\text { sec }\end{array}$ & $\begin{array}{l}\text { Angle } \\
\text { deg }\end{array}$ & $\begin{array}{l}\text { Speed } \\
\mathrm{mph}\end{array}$ & $\begin{array}{l}\text { Dir. } \\
\text { deg }\end{array}$ & $\begin{array}{l}H_{\text {sdiff, }} \\
\mathrm{ft}\end{array}$ & $\begin{array}{l}H_{\text {sloc }} \\
\mathrm{ft}\end{array}$ & $\begin{array}{l}\text { Storm } \\
\text { Surge } \\
\mathrm{ft}\end{array}$ & $\begin{array}{l}\text { Total } \\
\mathrm{ft}\end{array}$ \\
\hline 2348 & 24.0 & 11 & 338 & 54 & 250 & 0.0 & 3.9 & 0.5 & 3.6 \\
\hline 0150 & 19.7 & 14 & 230 & 38 & 120 & 0.0 & 0.0 & 0.1 & 1.0 \\
\hline 0853 & 32.8 & 13 & 295 & 56 & 220 & 3.6 & 1.9 & 0.8 & 3.8 \\
\hline 1953 & 29.9 & 14 & 277 & 49 & 170 & 3.9 & 0.9 & 0.2 & 3.1 \\
\hline 1557 & 21.3 & 13 & 313 & 38 & 240 & 2.4 & 2.4 & 0.3 & 3.0 \\
\hline 2057 & 51.5 & 14 & 14 & 0 & - & 0.0 & 0.0 & 0.7 & 1.6 \\
\hline 1861 & 20.0 & 17 & 245 & 38 & 125 & 3.6 & 0.0 & -0.1 & 2.6 \\
\hline 2762 & 39.0 & 17 & 18 & 101 & 140 & 0.0 & 2.3 & 1.3 & 3.5 \\
\hline 0163 & 49.5 & 17 & 288 & 69 & 240 & 7.0 & 5.0 & 1.1 & 6.5 \\
\hline 2563 & 37.1 & 13 & 292 & 67 & 245 & 4.0 & 4.9 & 0.8 & 5.1 \\
\hline 2965 & 15.1 & 9 & 310 & 34 & 250 & 1.1 & 2.2 & 0.1 & 2.4 \\
\hline 3367 & 49.5 & 14 & 302 & 76 & 235 & 5.2 & 4.6 & 1.2 & 5.7 \\
\hline 2168 & 24.9 & 13 & 299 & 47 & 235 & 2.9 & 2.6 & 0.4 & 3.3 \\
\hline 0571 & 29.2 & 17 & 270 & 45 & 170 & 5.0 & 0.8 & 0.8 & 4.2 \\
\hline 0676 & 43.0 & 14 & 320 & 83 & 250 & 0.0 & 6.6 & 2.5 & 7.0 \\
\hline 1977 & 22.3 & 11 & 245 & 56 & 170 & 1.8 & 1.1 & 0.3 & 2.3 \\
\hline 2379 & 11.5 & 14 & 248 & 31 & 130 & 1.6 & 0.0 & 0.0 & 1.6 \\
\hline 2187 & 24.9 & 11 & 295 & 43 & 250 & 2.0 & 2.9 & 0.2 & 3.1 \\
\hline 0188 & 52.2 & 14 & 310 & 87 & 250 & 5.2 & 7.0 & 1.7 & 7.3 \\
\hline 0289 & 27.9 & 13 & 356 & 27 & 330 & 0.0 & 0.0 & 0.6 & 1.5 \\
\hline 0190 & 21.0 & 14 & 14 & 36 & 255 & 0.0 & 2.1 & 0.2 & 2.3 \\
\hline 3190 & 39.7 & 14 & 11 & 0 & - & 0.0 & 0.0 & 0.4 & 1.4 \\
\hline 2691 & 23.3 & 11 & 302 & 38 & 240 & 1.9 & 2.4 & -0.1 & 2.5 \\
\hline 1592 & 35.8 & 14 & 317 & 81 & 195 & 3.9 & 2.1 & 1.6 & 4.8 \\
\hline 3192 & 32.2 & 14 & 11 & 58 & 135 & 0.0 & 0.8 & 1.4 & 2.7 \\
\hline 3594 & 11.2 & 7 & 277 & 27 & 260 & 0.9 & 1.3 & -0.1 & 1.7 \\
\hline 0597 & 65.0 & 17 & 313 & 98 & 250 & 7.2 & 8.2 & 2.4 & 9.1 \\
\hline 2997 & 36.7 & 13 & 302 & 69 & 245 & 3.9 & 5.1 & 0.9 & 5.3 \\
\hline 5163 & 47.9 & 14 & 313 & 72 & 270 & 4.8 & 1.6 & 1.3 & 4.8 \\
\hline 6163 & 44.0 & 14 & 259 & 67 & 205 & 5.1 & 1.9 & 1.1 & 4.7 \\
\hline
\end{tabular}




\begin{tabular}{|c|c|c|c|c|c|c|c|c|c|}
\hline \multirow[b]{2}{*}{ Storm } & \multicolumn{3}{|c|}{ Offshore Waves } & \multicolumn{2}{|c|}{ Local Wind } & \multicolumn{2}{|c|}{ Local Waves } & \multicolumn{2}{|c|}{ Water Level } \\
\hline & $\begin{array}{l}\text { Height } \\
\mathrm{ft}\end{array}$ & $\begin{array}{l}\text { Period } \\
\text { sec }\end{array}$ & $\begin{array}{l}\text { Angle } \\
\text { deg }\end{array}$ & $\begin{array}{l}\text { Speed } \\
\mathrm{mph}\end{array}$ & $\begin{array}{l}\text { Dir. } \\
\text { deg }\end{array}$ & $\begin{array}{l}H_{\text {sdiff }} \\
\mathrm{ft}\end{array}$ & $\begin{array}{l}H_{\text {sloc }} \\
\mathrm{ft} \\
\end{array}$ & $\begin{array}{l}\text { Storm } \\
\text { Surge } \\
\mathrm{ft} \\
\end{array}$ & $\begin{array}{l}\text { Total } \\
\mathrm{ft}\end{array}$ \\
\hline 2348 & 24.0 & 11 & 338 & 54 & 250 & 0.0 & 2.7 & 0.5 & 2.9 \\
\hline 0150 & 19.7 & 14 & 230 & 38 & 120 & 0.0 & 0.0 & 0.1 & 1.0 \\
\hline 0853 & 32.8 & 13 & 295 & 56 & 220 & 4.0 & 2.4 & 0.8 & 4.0 \\
\hline 1953 & 29.5 & 13 & 256 & 49 & 185 & 3.7 & 1.2 & 0.3 & 3.2 \\
\hline 1557 & 21.3 & 13 & 313 & 38 & 240 & 2.6 & 2.4 & 0.3 & 3.0 \\
\hline 2057 & 51.5 & 14 & 14 & 0 & - & 0.0 & 0.0 & 0.7 & 1.5 \\
\hline 1861 & 20.0 & 17 & 245 & 38 & 125 & 2.7 & 0.0 & -0.1 & 2.1 \\
\hline 2762 & 39.0 & 17 & 18 & 101 & 140 & 0.0 & 2.7 & 1.4 & 3.7 \\
\hline 0163 & 49.5 & 17 & 288 & 69 & 240 & 5.7 & 5.0 & 1.1 & 6.0 \\
\hline 2563 & 38.7 & 13 & 274 & 67 & 235 & 4.5 & 3.9 & 0.9 & 4.9 \\
\hline 2965 & 16.1 & 9 & 284 & 34 & 240 & 1.4 & 2.0 & 0.1 & 2.4 \\
\hline 3367 & 49.5 & 14 & 302 & 76 & 235 & 5.6 & 4.6 & 1.2 & 5.9 \\
\hline 2168 & 24.9 & 13 & 299 & 47 & 235 & 3.2 & 2.5 & 0.4 & 3.4 \\
\hline 0571 & 29.2 & 17 & 270 & 45 & 170 & 3.9 & 1.0 & 0.8 & 3.7 \\
\hline 0676 & 43.6 & 14 & 292 & 85 & 235 & 5.2 & 5.3 & 2.1 & 6.9 \\
\hline 1977 & 22.3 & 11 & 245 & 56 & 170 & 2.0 & 1.3 & 0.3 & 2.4 \\
\hline 2379 & 11.5 & 14 & 248 & 31 & 130 & 1.5 & 0.0 & 0.0 & 1.6 \\
\hline 2187 & 24.9 & 11 & 295 & 43 & 250 & 2.2 & 2.0 & 0.2 & 2.7 \\
\hline 0188 & 52.2 & 14 & 310 & 87 & 250 & 5.6 & 4.9 & 1.7 & 6.6 \\
\hline 0289 & 29.9 & 13 & 349 & 27 & 320 & 0.0 & 0.0 & 0.6 & 1.4 \\
\hline 0190 & 23.3 & 11 & 302 & 38 & 270 & 2.1 & 0.5 & 0.2 & 2.2 \\
\hline 3190 & 39.7 & 14 & 11 & 0 & - & 0.0 & 0.0 & 0.4 & 1.4 \\
\hline 2691 & 23.3 & 11 & 302 & 38 & 240 & 2.1 & 2.4 & -0.1 & 2.5 \\
\hline 1592 & 35.8 & 14 & 317 & 81 & 195 & 4.2 & 2.4 & 1.6 & 5.0 \\
\hline 3192 & 32.2 & 14 & 11 & 58 & 135 & 0.0 & 1.0 & 1.4 & 2.8 \\
\hline 3594 & 11.2 & 7 & 277 & 27 & 260 & 0.9 & 0.4 & -0.1 & 1.3 \\
\hline 0597 & 65.0 & 17 & 313 & 98 & 250 & 6.2 & 5.7 & 2.4 & 7.8 \\
\hline 2997 & 36.7 & 13 & 302 & 69 & 245 & 4.3 & 4.4 & 0.9 & 5.1 \\
\hline 5163 & 47.9 & 14 & 313 & 72 & 270 & 5.3 & 1.0 & 1.3 & 4.9 \\
\hline 6163 & 44.0 & 14 & 259 & 67 & 205 & 5.3 & 2.2 & 1.1 & 4.9 \\
\hline
\end{tabular}




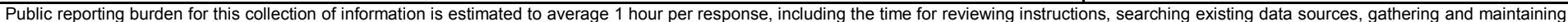

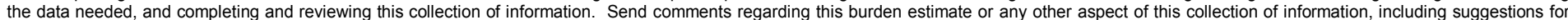

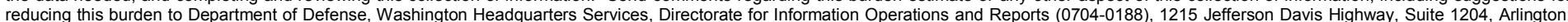

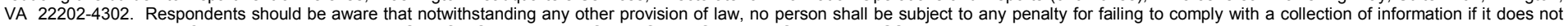
display a currently valid OMB control number. PLEASE DO NOT RETURN YOUR FORM TO THE ABOVE ADDRESS.

\begin{tabular}{l|c}
$\begin{array}{l}\text { 1. REPORT DATE }(D D-M M-Y Y Y Y) \\
\text { January } 2002\end{array}$ & $\begin{array}{c}\text { 2. REPORT TYPE } \\
\text { Final report }\end{array}$ \\
\hline
\end{tabular}

\section{TITLE AND SUBTITLE}

Typhoon-Induced Stage-Frequency and Overtopping Relationships for the Commercial

Port Road, Territory of Guam

3. DATES COVERED (From - To)

5a. CONTRACT NUMBER

5b. GRANT NUMBER

5c. PROGRAM ELEMENT NUMBER

\section{AUTHOR(S)}

\section{5d. PROJECT NUMBER}

Edward F. Thompson, Norman W. Scheffner

5e. TASK NUMBER

5f. WORK UNIT NUMBER

7. PERFORMING ORGANIZATION NAME(S) AND ADDRESS(ES)

8. PERFORMING ORGANIZATION REPORT NUMBER

U.S. Army Engineer Research and Development Center

Coastal and Hydraulics Laboratory

ERDC/CHL TR-02-1

3909 Halls Ferry Road

Vicksburg, MS 39180-6199

9. SPONSORING / MONITORING AGENCY NAME(S) AND ADDRESS(ES)

10. SPONSOR/MONITOR'S ACRONYM(S)

U.S. Army Engineer District, Honolulu

Fort Shafter, HI 96858-5440

11. SPONSOR/MONITOR'S REPORT NUMBER(S)

\section{DISTRIBUTION / AVAILABILITY STATEMENT}

Approved for public release; distribution is unlimited.

\section{SUPPLEMENTARY NOTES}

\section{ABSTRACT}

This report describes the procedures and results of a typhoon overtopping-frequency analysis for a vulnerable section of the commercial port road along Cabras Island, U.S. Territory of Guam. Numerical modeling of typhoon winds, waves, storm surge, and nearshore processes is used to estimate wave overtopping rates due to historical storm events. Alternatives modeled include the existing fringing reef, beach, and protective seawall, and a plan configuration in which a low-crested, Core-Loc-armored berm is included in the nearshore profile. Model overtopping rates are input to the Empirical Simulation Technique (EST) life-cycle stochastic model. Lifecycle simulations are postprocessed to generate overtopping rate frequency-of-occurrence relationships for return periods of up to 100 years. Model results indicate that the proposed low-crested berm to be built in the nearshore profile will significantly reduce the vulnerability of the road and port facilities to damage due to wave overtopping.

\section{SUBJECT TERMS}

Empirical simulation technique

Frequency analysis

16. SECURITY CLASSIFICATION OF:

\begin{tabular}{|l|l|}
\hline $\begin{array}{l}\text { a. } \text { REPORT } \\
\text { UNCLASSIFIED }\end{array}$ & $\begin{array}{l}\text { b. ABSTRACT } \\
\text { UNCLASSIFIED }\end{array}$ \\
\hline
\end{tabular}

Hurricane modeling

Numerical modeling Storm surge

| 17.

c. THIS PAGE

UNCLASSIFIED
Wave overtopping

Wave setup

Wind wave modeling

\begin{tabular}{l|c|l|}
$\begin{array}{l}\text { 17. LIMITATION } \\
\text { OF ABSTRACT }\end{array}$ & $\begin{array}{l}\text { 18. NUMBER } \\
\text { OF PAGES }\end{array}$ & $\begin{array}{l}\text { 19a. NAME OF RESPONSIBLE } \\
\text { PERSON }\end{array}$ \\
\cline { 3 - 3 } & 127 & $\begin{array}{l}\text { 19b. TELEPHONE NUMBER (include } \\
\text { area code) }\end{array}$ \\
& &
\end{tabular}

